\title{
FULL SCALE BIOREACTOR LANDFILL FOR CARBON SEQUESTRATION AND GREENHOUSE EMISSION CONTROL
}

\section{Quarterly Technical Progress Report}

Reporting Period Start Date: January 1, 2003

Reporting Period End Date: March 31, 2003

Principal Author(s)

Ramin Yazdani, Senior Civil Engineer, Yolo County Public Works, California Jeff Kieffer, Associate Civil Engineer, Yolo County Public Works, California Heather Akau, Junior Engineer, Yolo County Public Works, California

Date Report Issued

May 2003

D.O.E. Award Number

DE-FC26-01NT41152

Name and Address of Submitting Organization

Yolo County, Planning and Public Works Department

Attn: Ramin Yazdani

292 West Beamer Street

Woodland, CA 95695 


\section{DISCLAIMER}

This report was prepared as an account of work sponsored by an agency of the United States Government. Neither the United States Government nor any agency thereof, nor any of their employees, makes any warranty, express or implied, or assumes any legal liability or responsibility for the accuracy, completeness, or usefulness of any information, apparatus, product, or process disclosed, or represents that its use would not infringe privately owned rights. Reference herein to any specific commercial product, process, or service by trade name, trademark, manufacturer, or otherwise does not necessarily constitute or imply its endorsement, recommendation, or favoring by the United States Government or any agency thereof. The views and opinions of the authors expressed herein do not necessarily state or reflect those of the United States Government or any agency thereof. 


\begin{abstract}
The Yolo County Department of Planning and Public Works is constructing a full-scale bioreactor landfill as a part of the Environmental Protection Agency's (EPA) Project XL program to develop innovative approaches for carbon sequestration and greenhouse emission control. The overall objective is to manage landfill solid waste for rapid waste decomposition and maximum landfill gas generation and capture for carbon sequestration and greenhouse emission control. Waste decomposition is accelerated by improving conditions for either the aerobic or anaerobic biological processes and involves circulating controlled quantities of liquid (leachate, groundwater, gray water, etc.), and, in the aerobic process, large volumes of air.

The first phase of the project entails the construction of a 12-acre module that contains a 6-acre anaerobic cell, a 3.5-acre anaerobic cell, and a 2.5-acre aerobic cell at the Yolo County Central Landfill near Davis, California. The cells are highly instrumented to monitor bioreactor performance. Construction is complete on the 3.5-acre anaerobic cell and liquid addition has commenced. Construction of the 2.5 -acre aerobic cell is nearly complete with only the biofilter remaining and construction of the west-side 6-acre anaerobic cell is nearly complete with only the liquid addition system remaining. The current project status and preliminary monitoring results are summarized in this report.
\end{abstract}




\section{DISCLAIMER}

\section{TABLE OF CONTENTS}

\section{ABSTRACT}

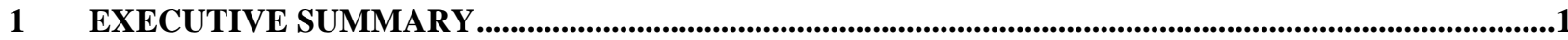

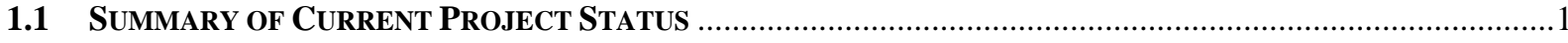

2 INTRODUCTION.........................................................................................................................................4

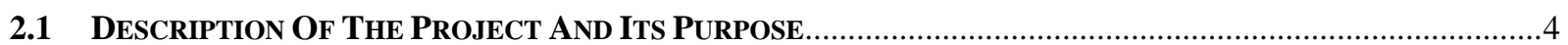

2.2 DESCRIPTION OF THE FACILITY AND ThE OPERATIONS / GEOGRAPHIC AREA ...................................5

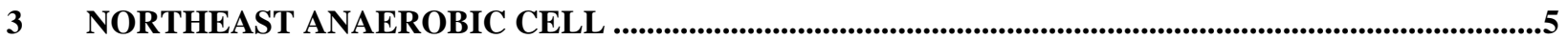

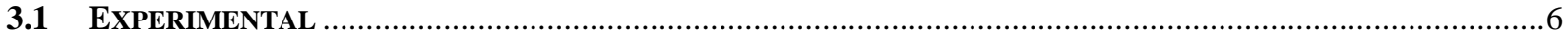

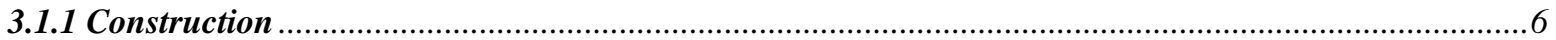

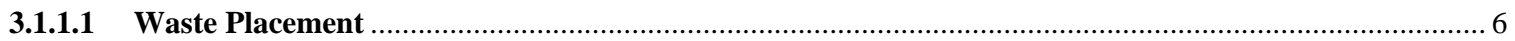

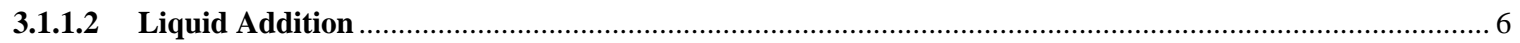

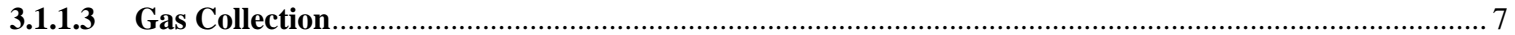

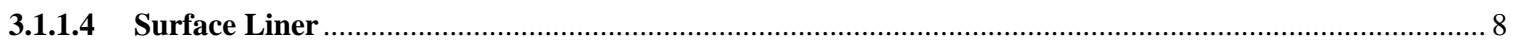

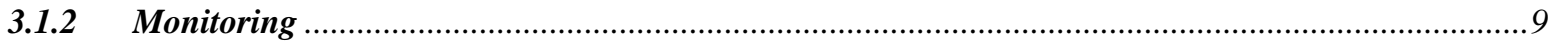

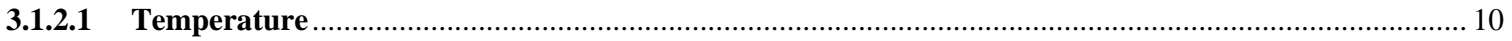

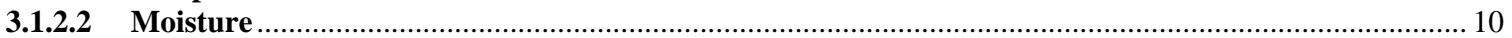

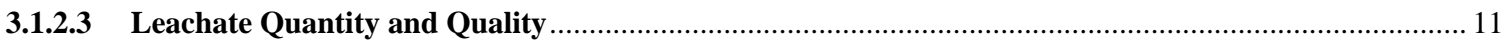

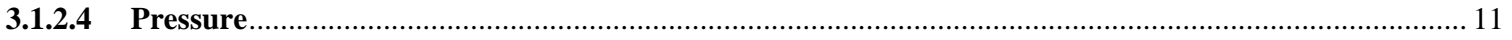

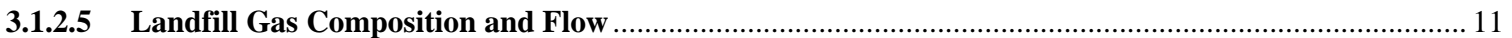

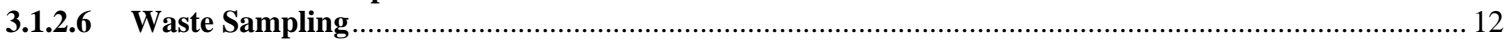

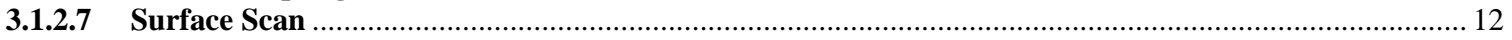

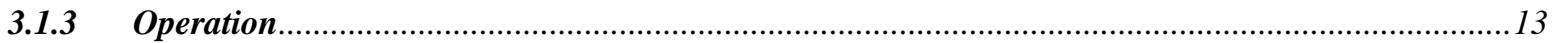

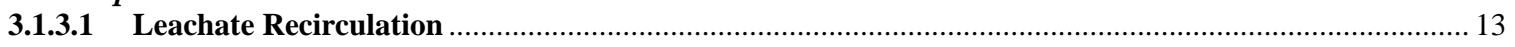

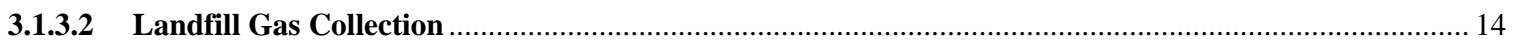

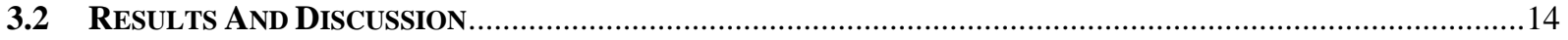

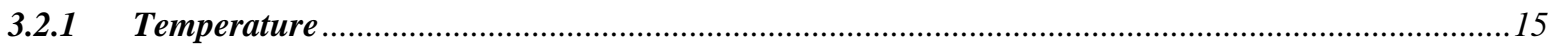

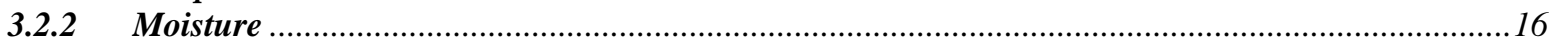

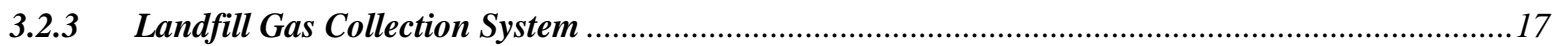

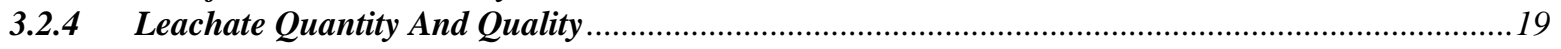

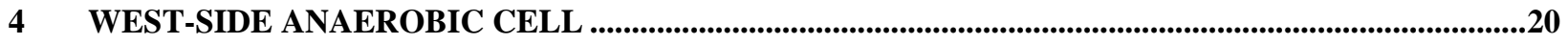

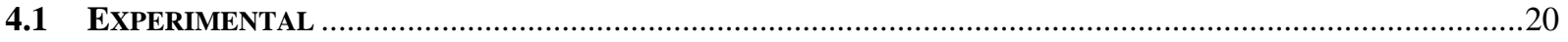

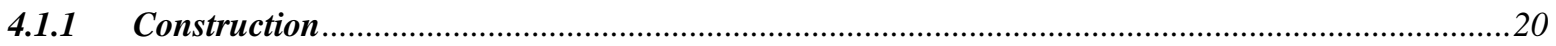

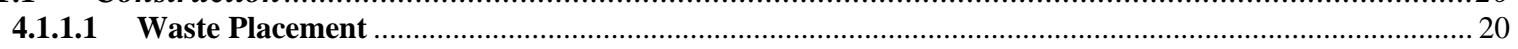

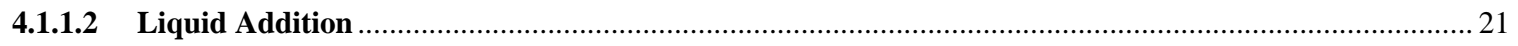

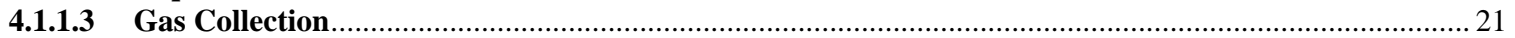

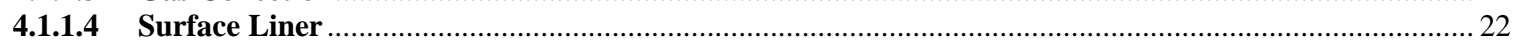

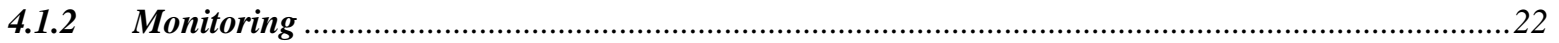

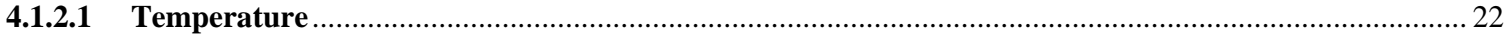

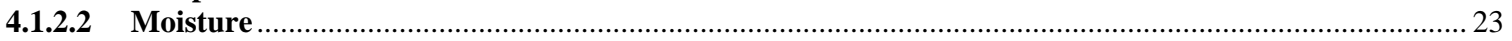

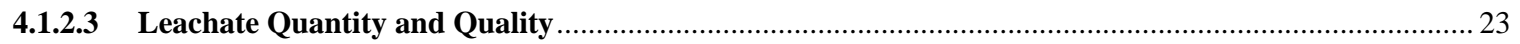

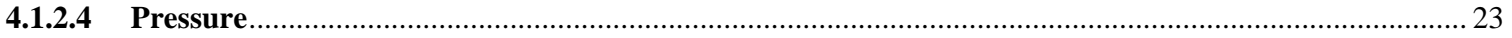

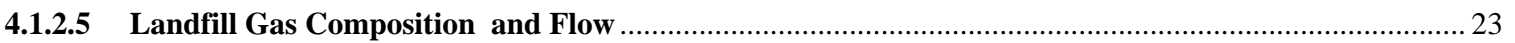

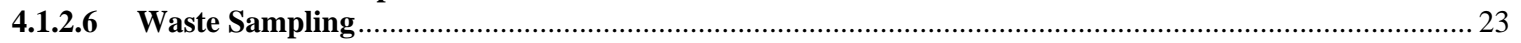

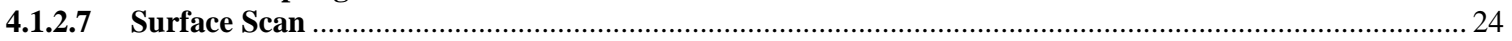

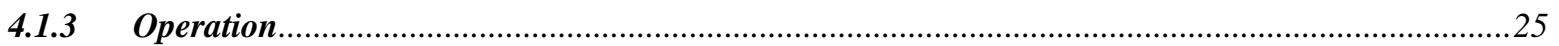

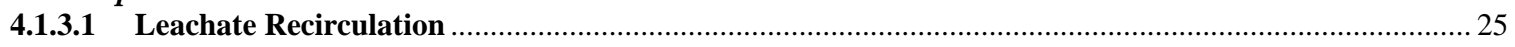

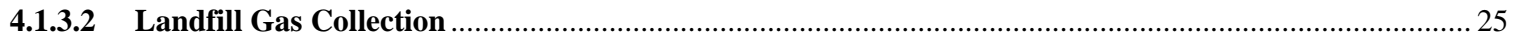

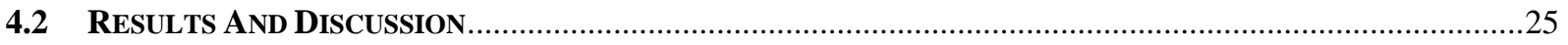

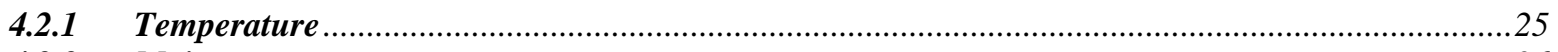

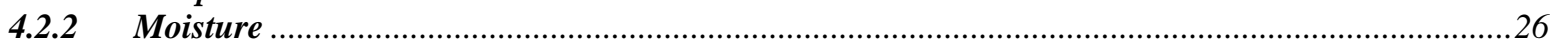

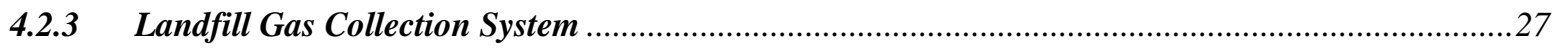

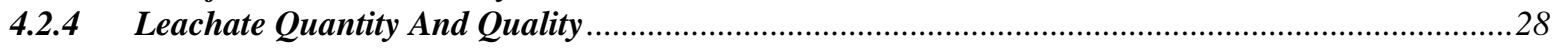




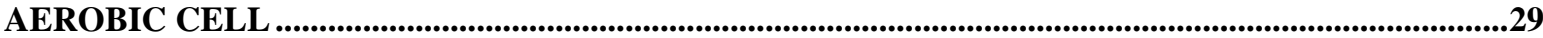

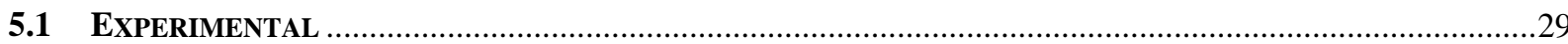

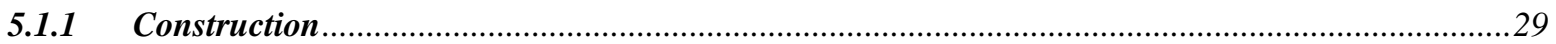

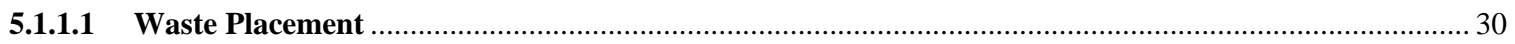

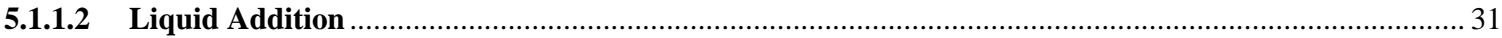

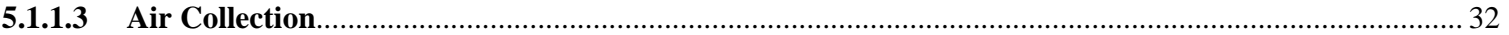

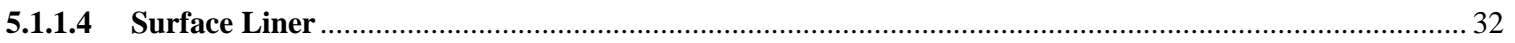

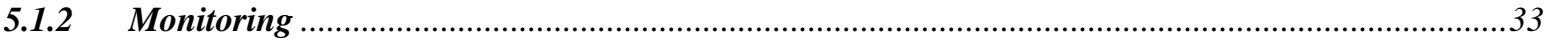

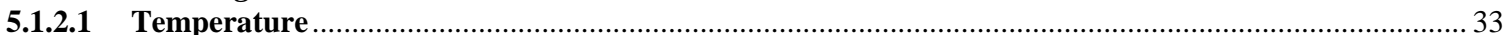

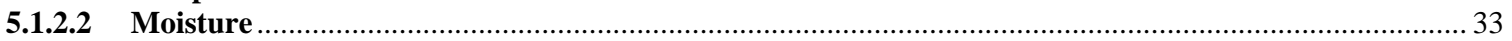

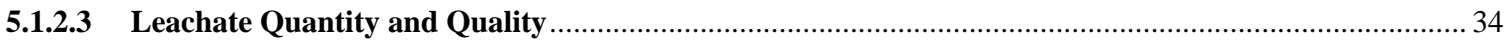

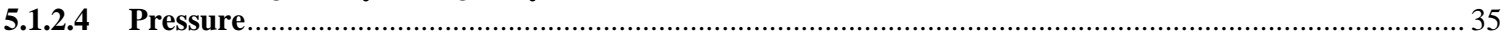

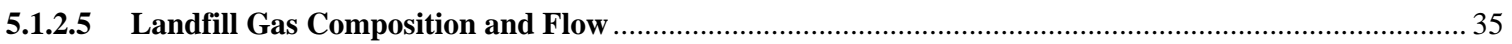

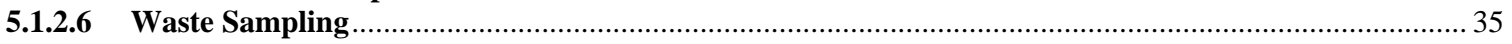

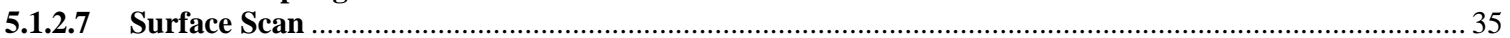

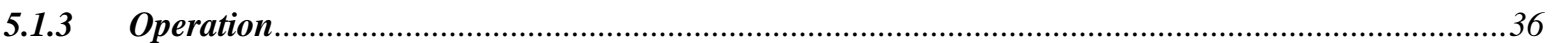

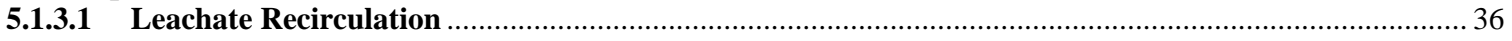

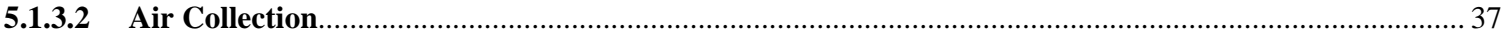

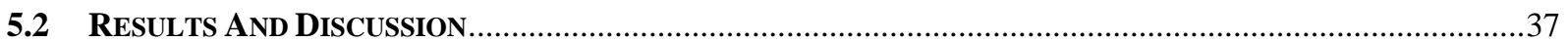

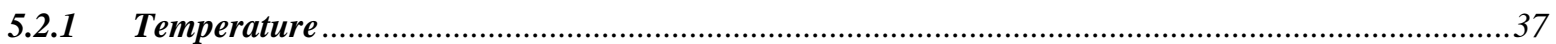

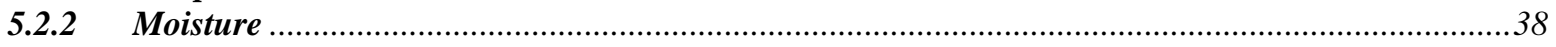

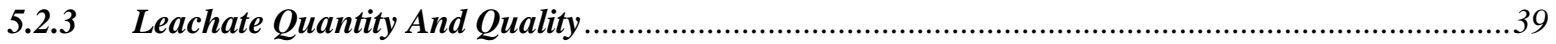

6 MODULE 6D BASE LINER ..................................................................................................................40

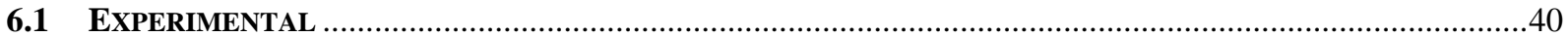

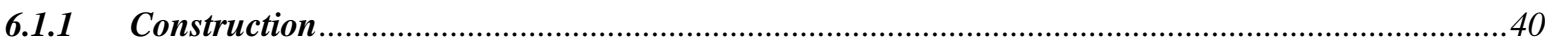

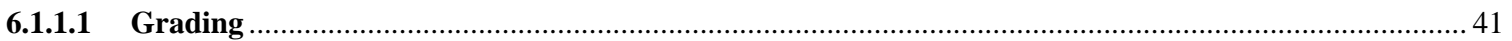

6.1.1.2 Base Liner Assembly

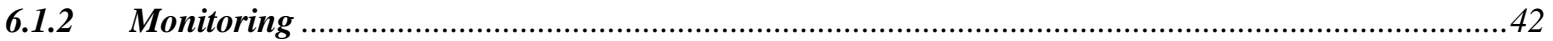

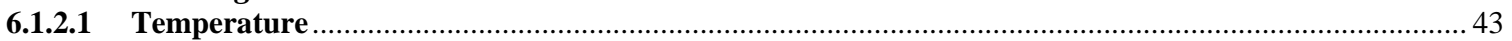

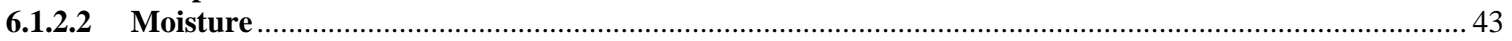

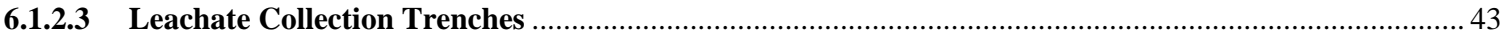

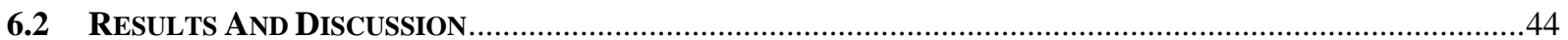

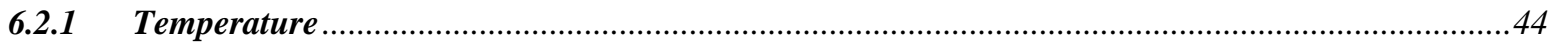

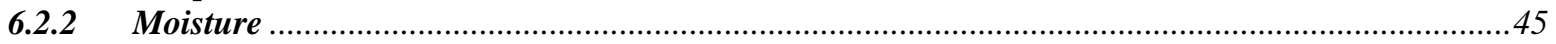

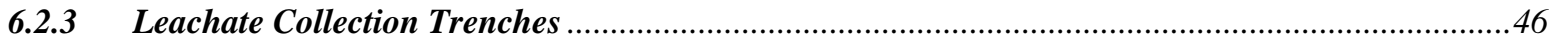

7 SUPERVISORY CONTROL AND DATA ACQUISITION SYSTEM (SCADA) .................................47

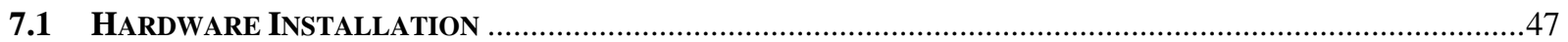

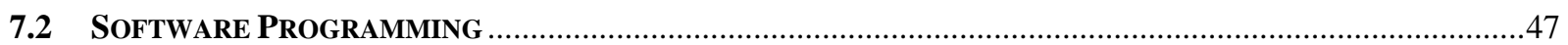

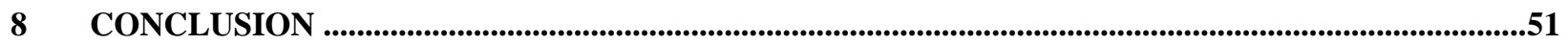

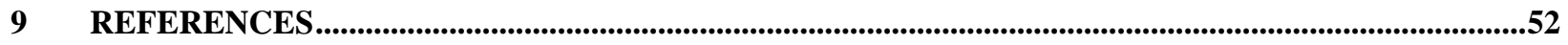

APPENDIX A- EPA XL SCHEDULE AND SUMMARY OF MATERIALS INSTALLED .........................53

APPENDIX B- PIPING AND INSTRUMENTATION PLANS .....................................................................63

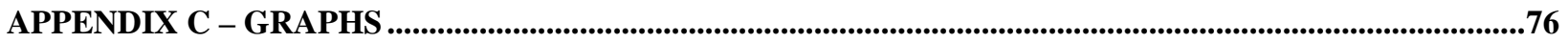

APPENDIX D- GAS LABORATORY CHEMISTRY ..............................................................................117

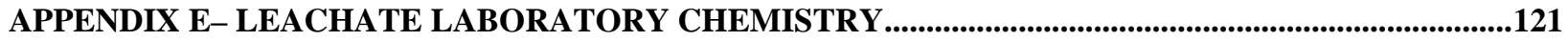




\section{LIST OF FIGURES}

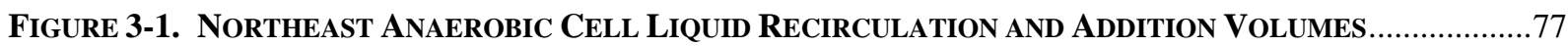

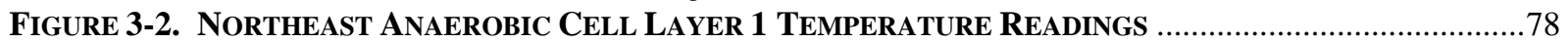

Figure 3-3. Northeast ANaERobic Cell Layer 2 Temperature ReadingS .......................................79

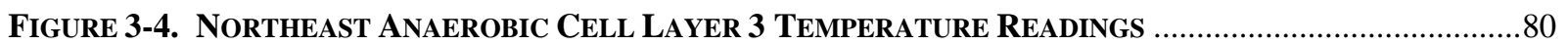

Figure 3-5. Northeast Anaerobic Cell Selected Temperature Readings........................................ 81

Figure 3-6. Northeast Anaerobic Cell Average Temperature ReadingS.........................................15

Figure 3-7. Northeast ANAERobic Cell LaYer 1 PVC Moisture ReadingS.........................................8 82

Figure 3-8. Northeast ANaERobic Cell Layer 2 PVC Moisture ReadingS........................................8 83

Figure 3-9. Northeast Anaerobic Cell Layer 2 Gypsum in Plaster Moisture Readings .................84

Figure 3-10. Northeast ANaErobic Cell Layer 2 Gypsum in SoIl Moisture Readings ......................85

Figure 3-11. Northeast ANaERobic Cell LaYer 3 PVC Moisture Readings.......................................86

Figure 3-12. Northeast ANaErobic CELl AVERage Moisture ReadingS .............................................17

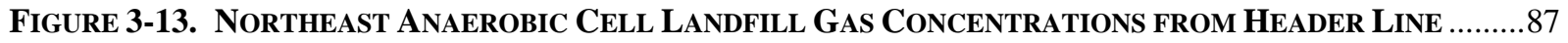

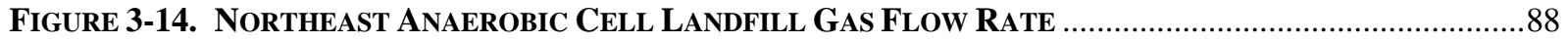

Figure 3-15. Northeast Anaerobic Cell Cumulative Methane .............................................................8

Figure 3-16. CUMUlative Methane From Northeast ANAERobic CELL AND ENHANCED CELL ..............90

FigURE 3-17. ChANGE IN VOC CONCENTRATIONS IN LFG FROM THE NORTHEAST ANAEROBIC CELL .........18

Figure 4-1. West-Side Anaerobic Cell Layer 1 Temperature Readings ..........................................91

FigURE 4-2. WEST-SIDE ANAEROBIC CELl LAYER 2 TEMPERATURE READINGS .........................................92

Figure 4-3. WeSt-Side Anaerobic Cell Layer 3 Temperature REAdingS ............................................93

Figure 4-4. West-Side Anaerobic Cell AVErage Temperature ReadingS ..........................................26

Figure 4-5. WEST-SIDE ANAEROBIC CELL LAYER 1 PVC MOISTURE READINGS .........................................94

FIGURE 4-6. WEST-SIDE ANAEROBIC CELL LAYER 2 PVC READINGS..............................................................95

FigURE 4-7. WEST-SIDE ANAEROBIC CELL LAYER 3 PVC MOISTURE READINGS .........................................96

Figure 4-8. West-Side Anaerobic Cell AVErage PVC Moisture ReadingS ......................................27

Figure 4-9. WeSt-Side ANAEROBIC CELl LANDFILl GaS CONCENTRATIONS From HEADER LiNe .............97

Figure 4-10. WeSt-Side ANAERobic Cell Landfill Gas Flow RATE..................................................98

Figure 4-11. WeSt-Side Anaerobic Cell Cumulative Methane ……..................................................99

FiguRE 4-12. CUMUlative LEACHATE REMOVED FROM THE WEST-SIDE LCRS ....................................... 100

Figure 5-1. Aerobic Cell Base Liner Temperature Readings ..................................................... 101

Figure 5-2. Aerobic Cell Layer 0.5 Temperature ReadingS ....................................................... 102

Figure 5-3. AERobic Cell LaYer 1 TEMPERature ReadingS ............................................................. 103

Figure 5-4. AERobic Cell LaYer 2 TEMPERature ReadingS ............................................................ 104

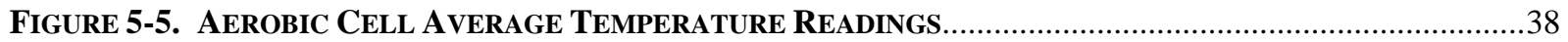

Figure 5-6. Aerobic Cell base Liner PVC Moisture Readings ................................................... 105

Figure 5-7. Aerobic Cell Layer 0.5 PVC Moisture ReadingS .........................................................106

Figure 5-8. AERobic Cell LaYer 1 PVC MoISTURE ReadingS ............................................................ 107

Figure 5-9. Aerobic Cell LaYer 2 PVC MoISTURe ReadingS ...................................................... 108

Figure 5-10. AERobic CELl AVERage PVC MoISTURe ReadingS............................................................39

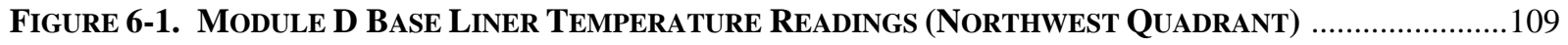

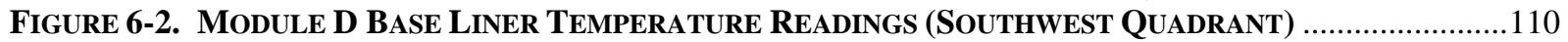

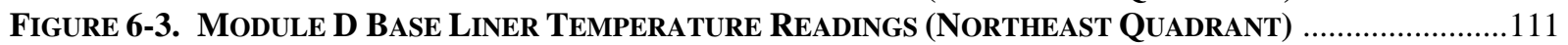

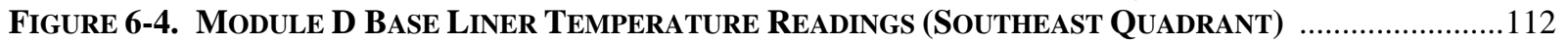

Figure 6-5. Module D BaSe Liner AVERAge Temperature ReadingS ................................................45

Figure 6-6. Module D BaSe Liner PVC Moisture ReadingS (WeSt Side Quadrants) .......................113

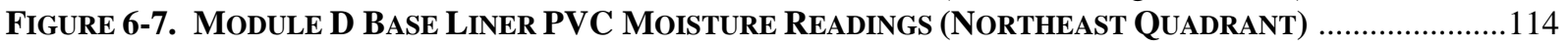

Figure 6-8. Module D BaSe Liner PVC Moisture Readings (SOUTHEAST QUAdRant) .......................115

Figure 6-9. MOdUle D BaSe Liner AVERAGE PVC MoISTURe ReadingS ................................................46

Figure 6-10. Module D Base Liner Pressure Transducers and Adjacent Tubes ............................116 


\section{LIST OF TABLES}

TABle 1-1. ReVised Project Xl Delivery SChedule. .54

TABLE 3-1. SUMMARY OF DATA FOR THE NORTHEAST ANAEROBIC CELL ………………………....................5

TABLE 3-2. SUMMARY OF SENSORS FOR THE ANAEROBIC CELLS ........................................................56

TABLE 3-3. SUMMARY OF GAS COLLECTION LINES FOR THE NORTHEAST ANAEROBIC CELL...........................57

Table 3-4. Summary of Surface Scans Performed on the Northeast Anaerobic Cell.....................13

TABLE 3-5. TEMPERATURE SUMMARY FOR THE NORTHEAST ANAEROBIC CELL ………...............................15

TABLE 3-6. PVC MoISTURE SUMmary FOR THE NORTHEAST ANAEROBIC CELL .........................................16

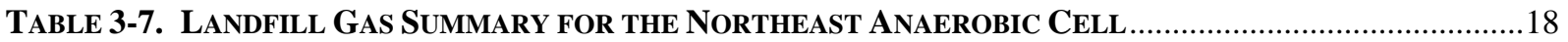

TABLE 3-8. ANALYTICAL RESUltS FOR LANDFILL GAS SAMPLED FROM MODULE D .................................118

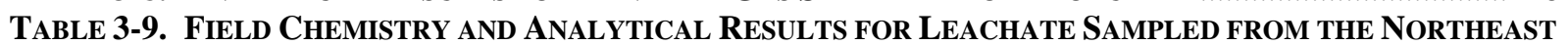

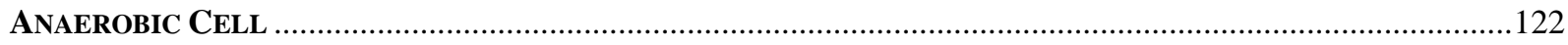

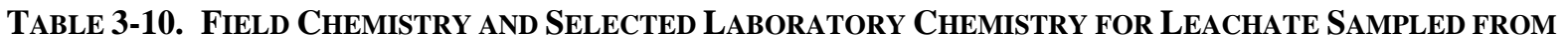

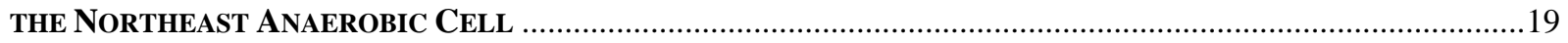

TABLE 4-1. SUMmary OF DATA FOR THE WeST-Side ANAEROBIC CELL ……............................................58

TABLE 4-2. SuMmary OF GAS COLLECTION LINES FOR THE WEST-Side ANAEROBIC CELL ............................59

Table 4-3. Summary of Surface Scans Performed on the West-Side Anaerobic Cell ....................24

TABLE 4-4. TeMPERATURE SUMMARY FOR THE WEST-Side ANAEROBIC CELL ..............................................25

TABLE 4-5. PVC MoISTURe Summary FOR THE WEST-Side ANAERobic CELL ............................................27

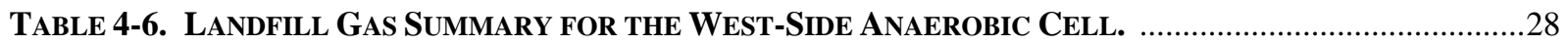

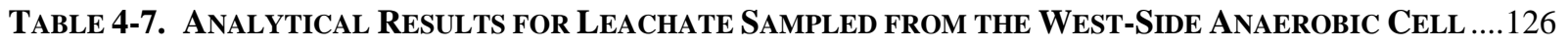

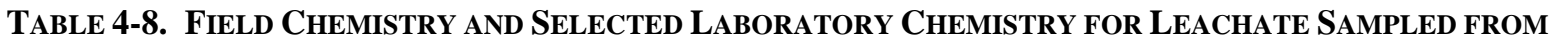

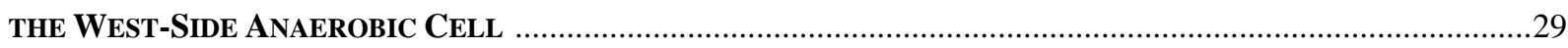

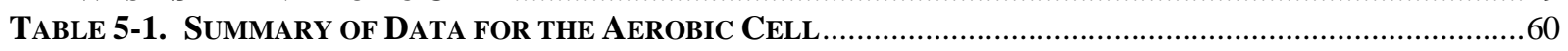

TABLE 5-2. SUMMARY OF SENSORS FOR THE AEROBIC CELL ……….....................................................61

TABle 5-3. Summary of Air Collection Lines for the Aerobic CELl …….........................................62

Table 5-4. Summary of SurfaCe SCans Performed on the Aerobic Cell ……………..........................36

TABLE 5-5. TEMPERATURE SUMMARY FOR THE AEROBIC CELL ...........................................................38

TABLE 5-6. PVC MoISTURE SUMMARY FOR THE AEROBIC CELL ……......................................................... 39

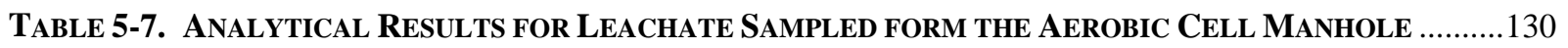

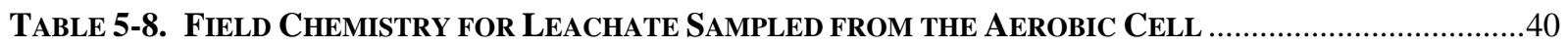

TABLE 6-1. SUMMARY OF SENSORS FOR THE MODULE 6D BASE LINER …………….....................................4

TABLE 6-2. PVC MOISTURE SUMMARY FOR THE BASE LINER …….......................................................... 46

TABLE 6-3. LEACHATE LEVEL SUMMARY FOR THE BASE LINER ................................................................4 


\section{EXECUTIVE SUMMARY}

In 1996, Yolo County began operation of a pilot-scale project to evaluate the costs and benefits of a relatively new concept in landfill operation, often termed "bioreactor" or "enhanced" landfilling. The basic concept of a bioreactor landfill is to increase the biological activity of the waste (through the addition of water) to maximize the production of landfill gas for carbon sequestration and greenhouse emission control. The results of this pilot project were favorable and, as a result, Yolo County requested and gained approval from state and federal regulatory agencies to conduct this full-scale demonstration of bioreactor landfilling.

Because current Federal and California State regulations generally do not allow the addition (or recirculation) of leachate and other supplemental liquid to a lined landfill module, special regulatory flexibility was required to conduct this project. Yolo County applied for, and was granted the necessary flexibility through the Unites States Environmental Protection Agency XL Program which stands for "eXcellence and Leadership." The XL program allows state and local governments, businesses and federal facilities to develop with EPA innovative strategies to test better or more cost-effective ways of achieving environmental and public health protection.

This report provides an update on Phase 1 of the Yolo County Accelerated Anaerobic and Aerobic Composting (Bioreactor) Project where carbon sequestration and greenhouse emission is controlled through either the anaerobic or aerobic process. Phase 1 of the project encompasses a 12-acre area of a 20-acre landfill module (Unit 6, Module D) at the Yolo County Central Landfill. Phase 2 of the project has begun with the construction of the primary liner system and installation of 12 temperature and moisture sensors. Waste placement in Phase 2 began in November 2002.

\subsection{Summary of Current Project Status}

The majority of the bioreactor project continues on schedule with the only deviations related to the aerobic cell's air collection system. The project schedule is located in Appendix A, Table 11 and has been altered since the previous project schedule prepared in January 2003.

The project bioreactors are separated into three landfill cells, two cells will be operated anaerobically and one aerobically (Detail 1-1). We have designated the three bioreactor cells as the west-side anaerobic cell, the northeast anaerobic cell, and the southeast aerobic cell. This configuration allowed the northeast anaerobic cell to be constructed and operated prior to completion of the west-side anaerobic cell. By separating the anaerobic bioreactor into two separate cells, experiences gained from construction of the northeast cell were incorporated into the west-side anaerobic cell. 


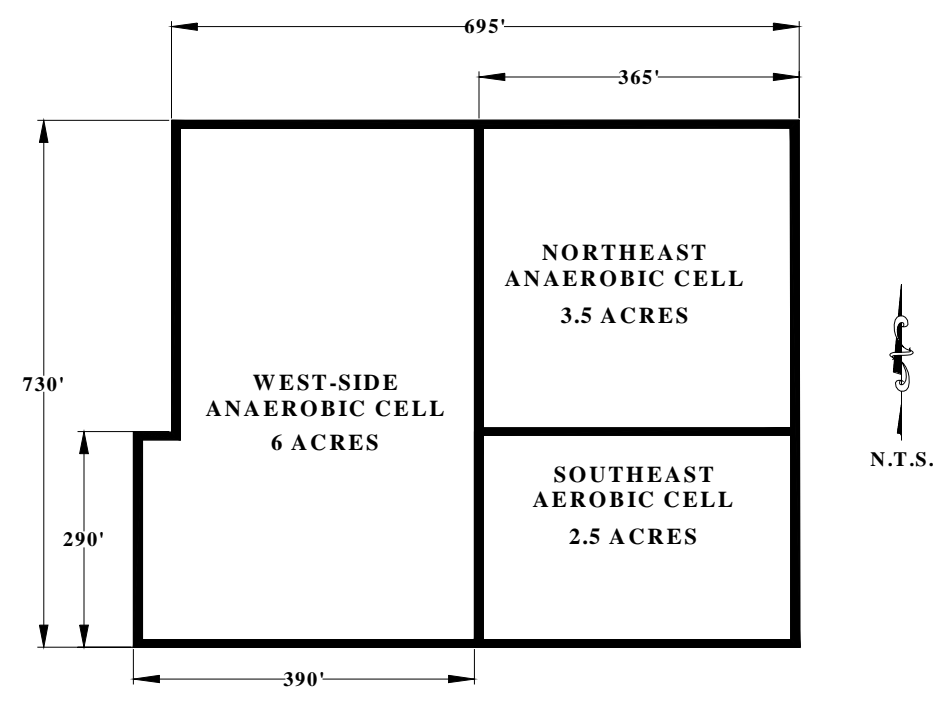

\section{Detail 1-1. Overview of Module D Bioreactor Cells}

The northeast anaerobic cell, the west-side anaerobic cell, and the southeast aerobic cell have been filled with waste and instrumentation. A total of 65,104 tons of waste was placed in the northeast anaerobic, 11,942 tons of waste was placed in the southeast aerobic module, and 166,294 tons of waste was placed in the west-side anaerobic cell. The gas collection systems have been completed in the northeast anaerobic cell and the west-side anaerobic cell while the biofilter remains to be completed for the aerobic cell. The leachate injection system has been completed in the northeast anaerobic cell and aerobic cell and is near completion in the west-side anaerobic cell.

The installation of a reinforced polypropylene (RPP) membrane surface cover over the northeast anaerobic cell was completed in November 2001 and will allow precise quantification of the amount of landfill gas produced by eliminating surface emissions. The aerobic cell received a cover of 12-inches of soil overlaid by 12 -inches of greenwaste alternative daily cover (ADC). The surface membrane cover for the west-side anaerobic cell is similar to the northeast anaerobic cell, with the exception that 40-mil linear low-density polyethylene (LLDPE) was used instead of RPP. Surface liner installation for the west-side anaerobic cell was completed in October 2002.

A Supervisory Control and Data Acquisition (SCADA) system has been installed and will monitor and control the operation of the bioreactor cells. To date, all instrumentation installed in the northeast and west-side anaerobic cells, the aerobic cell, and on the Module 6D composite liner have been connected to a central processor which is radio linked to a computer located in our Woodland office. In March 2002, the SCADA system started to electronically collect temperature and moisture data from in the northeast anaerobic cell, the aerobic cell, and on the Module 6D composite liner. In January 2003, the SCADA system started to electronically collect temperature and moisture data from in the west-side anaerobic cell.

Landfill gas collection began in the northeast anaerobic cell in mid-December 2001. Through the end of March 2003 a total of $22.3 \times 10^{6} \mathrm{scf}$ of methane (which is equivalent to approximately 
3500 barrels of oil) has been collected and utilized at the on-site gas to energy facility. Landfill gas from the main gas extraction header line on the northeast anaerobic cell was sampled and submitted for laboratory analysis in March 2003. Gas composition (methane, carbon dioxide, and oxygen) and pressure continues to be monitored on a weekly basis.

Landfill gas collection began in the west-side anaerobic cell in May 2002, and through the end of March 2003 a total of $5.3 \times 10^{6} \mathrm{scf}$ of methane (which is equivalent to approximately 850 barrels of oil) has been collected and utilized at the on-site gas to energy facility.

Leachate addition to the northeast cell began on March 27, 2002. Through the end of March 2003, a total of 1,563,042 gallons of supplemental liquid has been added and 548,462 gallons of leachate recirculated to the northeast anaerobic cell. Leachate was monitored for field chemistry and sampled for laboratory analysis in February 2003.

Monitoring for methane surface emissions has been performed quarterly since April 2002. During March 2003, a surface scan was performed on the northeast anaerobic cell and the westside anaerobic cell. The surface scan for the aerobic cell was postponed until April 2003 because of technical difficulties with the surface monitoring equipment. The highest methane surface emissions to date on the northeast anaerobic cell were detected in March 2003 at 70 parts per million (ppm). The high surface emissions in March 2003 can attributed high background readings, ranging between 60 and $65 \mathrm{ppm}$, that may be due Module D Phase II construction and changing wind currents carrying emissions from the west-side anaerobic cell. The highest methane surface emissions detected to date on the west-side anaerobic cell were also detected in March 2003 at $150 \mathrm{ppm}$. The high readings for the west-side anaerobic cell are due to a combination of high background readings, ranging between 60 and $75 \mathrm{ppm}$, and small gaps (less than 1 inch) between the surface liner and where the gas collection and leachate injection piping exits the cell (pipe penetrations). A follow-up surface scan will be performed in April 2003 to confirm these readings and steps will be taken to seal the pipe penetrations. 


\section{INTRODUCTION}

Sanitary landfilling is the dominant method of solid waste disposal in the United States, accounting for about 217 million tons of waste annually (U.S. EPA, 1997). The annual production of municipal solid waste in the United States has more than doubled since 1960. In spite of increasing rates of reuse and recycling, population and economic growth will continue to render landfilling as an important and necessary component of solid waste management.

In a Bioreactor Landfill, controlled quantities of liquid (leachate, groundwater, grey-water, etc.) are added to increase the moisture content of the waste. Leachate is then recirculated as necessary to maintain the moisture content of the waste at or near it's moisture holding capacity. This process significantly increases the biodegradation rate of waste and thus decreases the waste stabilization and composting time (5 to 10 years) relative to what would occur within a conventional landfill (30 to 50 years or more). If the waste decomposes (i. e., is composted) in the absence of oxygen (anaerobically), it produces landfill gas (biogas). Biogas is primarily a mixture of methane, a potent greenhouse gas, carbon dioxide, and small amounts of Volatile Organic Compounds (VOC's). This by-product of anaerobic landfill waste composting can be a substantial renewable energy resource that can be recovered for electricity or other uses. Other benefits of a bioreactor landfill composting operation include increased landfill waste settlement and a resulting increase in landfill capacity and life, improved opportunities for treatment of leachate liquid that may drain from fractions of the waste, possible reduction of landfill postclosure management time and activities, landfill mining, and abatement of greenhouse gases through highly efficient methane capture over a much shorter period of time than is typical of waste management through conventional landfilling.

\subsection{Description Of The Project And Its Purpose}

The County of Yolo Planning and Public Works Department (Yolo County) is operating its next 20-acre landfill module near Davis, California as a controlled bioreactor landfill to attain a number of superior environmental and cost savings benefits. In the first phase of this 20 -acre project, a 12-acre module will be constructed. This 12-acre module contains a 6-acre cell and a 3.5 -acre cell, which will be operated anaerobically, and a 2.5 -acre cell, which will be operated aerobically. The County began construction the second phase of Module 6D in Fall 2002 and, depending on the results of the first phase of Module 6D, Yolo County may operate the second phase either anaerobically or aerobically.

Co-sponsors of the project with Yolo County are the Solid Waste Association of North America (SWANA) and Institute for Environmental Management (IEM, Inc.). As part of the EPA Project XL, Yolo County requested that U.S. EPA grant site-specific regulatory flexibility from the prohibition in 40 CFR 258.28 Liquid Restrictions, which may preclude addition of useful bulk or non-containerized liquid amendments. The County intends to use leachate and groundwater first but if not enough liquid is available then other supplemental liquids such as gray-water from a waste water treatment plant, septic waste, and food-processing wastes will be used. Liquid wastes such as these, that normally have no beneficial use, may instead beneficially enhance the biodegradation of solid waste.

Yolo County also requested similar flexibility on liquid amendments from California and local regulatory entities. Several sections of the California Code of Regulations (CCR), Title 27, 
Environmental Protection, address the recirculation of liquids in lined municipal solid waste landfills. While the regulations do not specifically endorse bioreactors, regulatory flexibility is provided by the State of California Title 27, Chapter 3, Subchapter 2, Article 2, section 20200, Part (d)(3), Management of liquids at Landfills and Waste Piles. For additional information on this regulatory flexibility, see Section IV A of the FPA.

\subsection{Description Of The Facility And The Operations / Geographic Area}

The Yolo County Central Landfill (YCCL) is an existing Class III non-hazardous municipal solid waste landfill. The site encompasses a total of 722 acres and is comprised of 17 distinct Class III solid waste management units and two Class II leachate surface impoundments. The YCCL is located at the intersection of Road 104 and Road 28H, 2 miles northeast of the City of Davis. The YCCL was opened in 1975 for the disposal of non-hazardous solid waste, construction debris, and non-hazardous liquid waste. Existing on-site operations include a thirteen-year-old landfill methane gas recovery and energy generation facility, a drop-off area for recyclables, a metal recovery facility, a wood and yard waste recovery and processing area, and a concrete recycling area.

There are approximately 28 residences scattered within a 2-mile radius of the landfill. The closest residence is located several hundred feet south of the landfill, on the south side of Road 29 south of the Willow Slough By-pass.

Groundwater levels at the facility fluctuate between 8 to 10 feet during the year, rising from lowest in the Fall to highest in the Spring. Water level data indicate that the water table level is typically 4 to 10 feet below ground surface during winter and spring months. During summer and fall months, the water table is typically 5 to 15 feet below ground surface. In January 1989, the County of Yolo constructed a soil/bentonite slurry cutoff wall to retard groundwater flow to the landfill site from the north. The cutoff wall was constructed along portions of the northern and western boundaries of the site to a maximum depth of 44 feet. The cutoff wall has a total length of 3,680 feet, 2,880 feet along the north side and 800 feet along the west. In the fall of 1990, irrigation practices to the north of the landfill site were altered to minimize the infiltration of water.

Additionally, sixteen groundwater extraction wells were installed south of the cutoff wall in order to lower the water table south and east of the wall, to provide vertical separation between the base of the landfill and groundwater.

Prior to placement of the slurry wall and dewatering system, the groundwater flow direction was generally to the southeast. Under current dewatering conditions, the apparent groundwater flow paths are towards the extraction wells located along the western portion of the northern site boundary. In essence, a capture zone is created by the cone of depression created by the ground water extraction system, minimizing the possibility of off-site migration of contamination.

\section{NORTHEAST ANAEROBIC CELL}

The northeast anaerobic cell occupies approximately 3.5 acres in the northeast quadrant of Phase 1, Module 6D. 


\subsection{Experimental}

The experimental methods utilized are grouped into three categories: construction, monitoring, and operation. Each of these categories is discussed below.

\subsubsection{Construction}

Construction of the northeast anaerobic cell can be generally broken down into four major tasks: waste placement, liquid addition, gas collection, and surface liner installation. Each of these four tasks is discussed below. A summary of current monitoring data for the northeast anaerobic cell is provided in Appendix A, Table 3-1.

\subsubsection{Waste Placement}

Waste placement began on January 13, 2001 and was completed on August 3, 2001. Waste was placed in four separate lifts with an average thickness of 15 feet (Detail 3-1). In general, all waste received at the landfill was deposited in the northeast cell with the exception of self-haul waste. Because of the difficulties handling large volumes of self-haul vehicles in the limited area of the upper lifts, self-haul waste was not placed in lifts 3 and 4 . The use of daily cover soil during waste filling was minimized to aid in the overall permeability of the waste. Whenever possible, greenwaste or tarps were used as alternative daily cover (ADC) and, in the event soil was placed (for example, access roads or tipping pad), the soil was removed prior to placing the next lift of waste. All side slopes were constructed at approximately 2.5 to 1 (horizontal to vertical) and received at least one foot of soil cover. Instrumentation Layers 1, 2, and 3 were placed between lifts, and base layer instrumentation was installed on the Module 6D base liner. A summary of sensors installed on each layer is provided in Appendix A, Table 3-2.

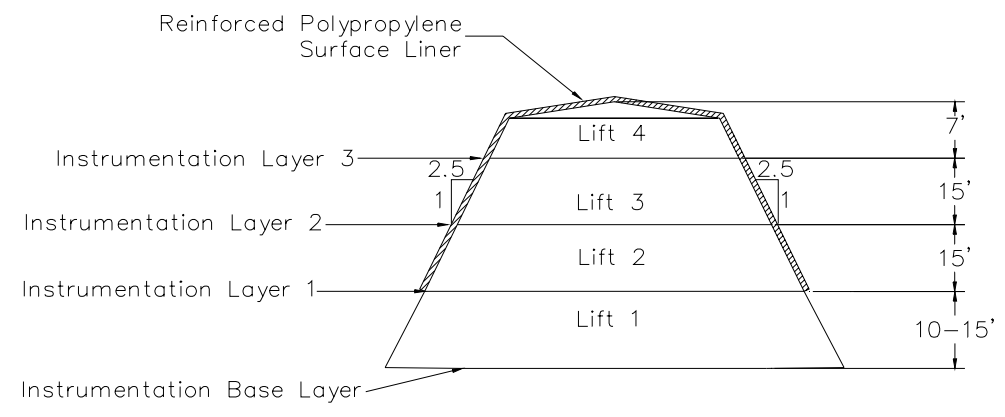

\section{Detail 3-1. Northeast Anaerobic Cell Cross Section}

\subsubsection{Liquid Addition}

Horizontal liquid injection lines were installed in each lift of waste (Image 3-1). Injection lines within the waste (between lifts 1 and 2,2 and 3, 3 and 4) were placed approximately every 40 feet. Injection lines installed on top of lift 4 were installed every 25 feet, with an additional injection line following the perimeter of the top deck. Each injection line consists of a 1.25-inch-diameter high-density polyethylene (HDPE) pipe placed horizontally (north to south), which extends completely through the waste. Each injection line was perforated by drilling a $3 / 32$-inch hole every 20 feet. A total of 8,130 feet of injection piping was installed with a total of 342 injection holes. 
Each of the injection laterals is connected to a 4-inch-diameter HDPE injection header. Leachate injection for each lateral will be monitored and controlled by individual solenoid valves connected to the SCADA system. A flow meter will monitor the total volume and injection flow rate for the entire northeast anaerobic cell.

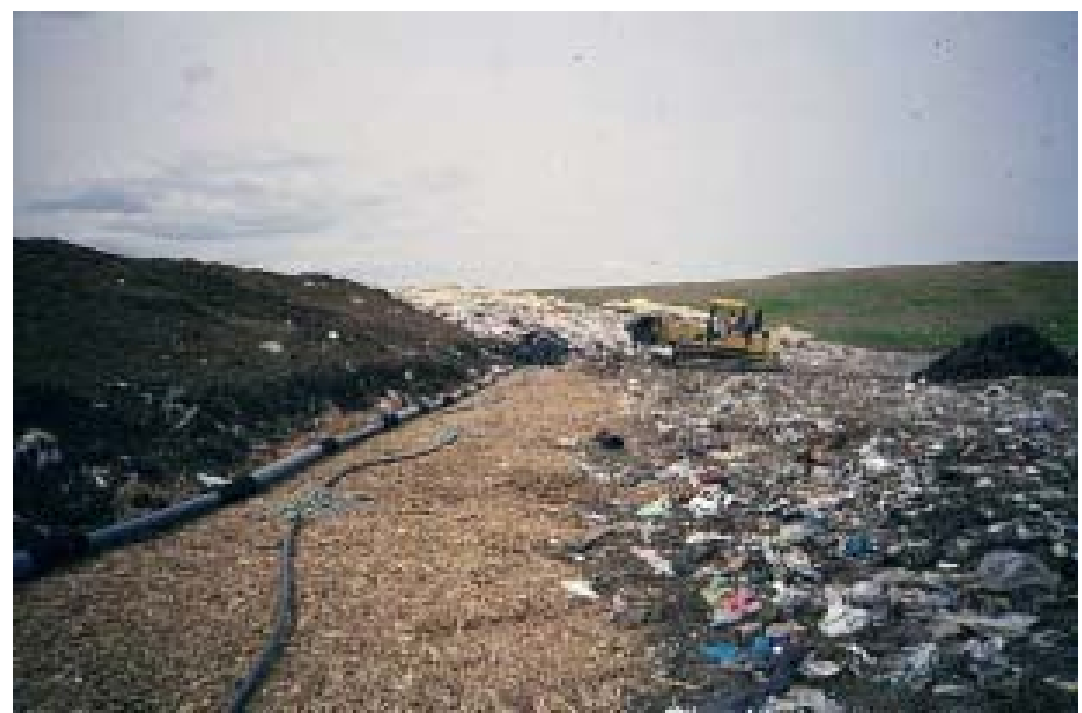

Image 3-1: Horizontal LFG and leachate injection lines installed and being coverd by shredded tires.

\subsubsection{Gas Collection}

Horizontal landfill gas (LFG) collection lines were installed between each lift of waste (Image 31) and directly under the reinforced polypropylene (RPP) geomembrane cover. LFG collection lines consist of various combinations of alternating 4 and 6-inch-diameter, schedule 80 polyvinyl chloride (PVC) pipe (Image 3-2) as well as several variations using corrugated HDPE pipe. A summary of gas collection lines for the northeast anaerobic cell is provided in Appendix A, Table 3-3. At each line, shredded tires were used as the permeable media. The gas collection lines between layers are spaced approximately 40 feet apart and the lines directly under the RPP membrane are spaced at 25 feet. A total of sixteen LFG collection lines were installed.

Each LFG collection line is connected to a 6-inch-diameter LFG collection header that conveys the gas to the on-site LFG-to-energy facility. Each LFG collection line incorporates a premanufactured wellhead capable of controlling flow and monitoring flow rate, temperature and pressure. 


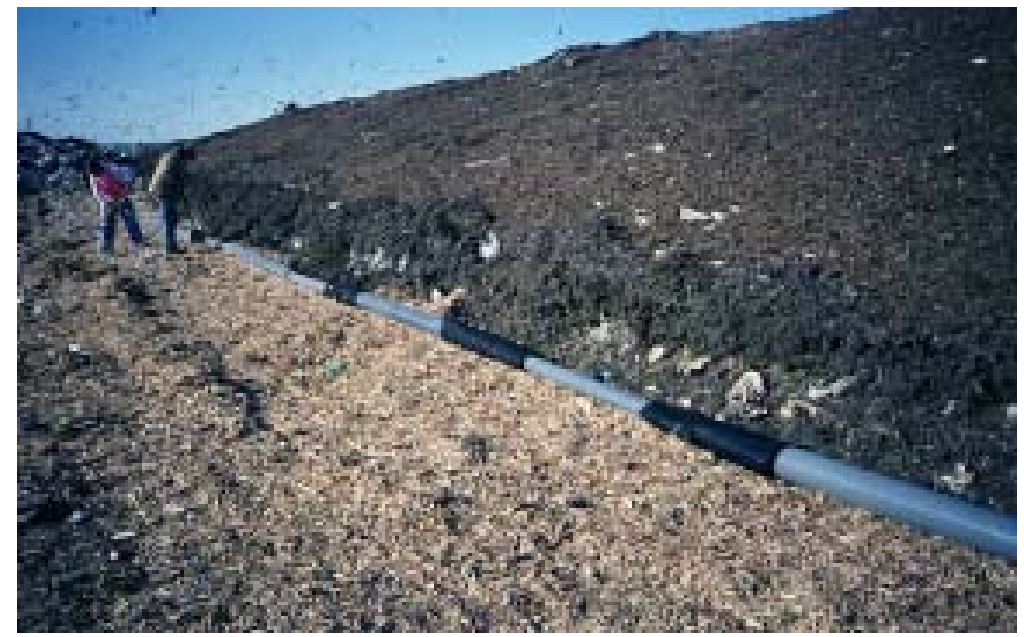

Image 3-2: Horizontal LFG collection line

\subsubsection{Surface Liner}

The County retained the services of Vector Engineering (Vector) to design the surface membrane covers for each of the bioreactor cells (Image 3-3). Their scope of work included the following subtasks:

- Research the different commercially available membrane materials, including high and low density polyethylene, polyvinyl chloride, and reinforced polypropylene;

- Design of a biofilter to treat the off-gas from the aerobic cell;

- Prepare plans and specification for the installation of the surface liners; and

- Provide on-site construction quality assurance for the installation of the surface membrane.

Vector's scope of work was modified to include preparation of plans and specifications for the tie-in of the leachate injection and landfill gas collection piping.

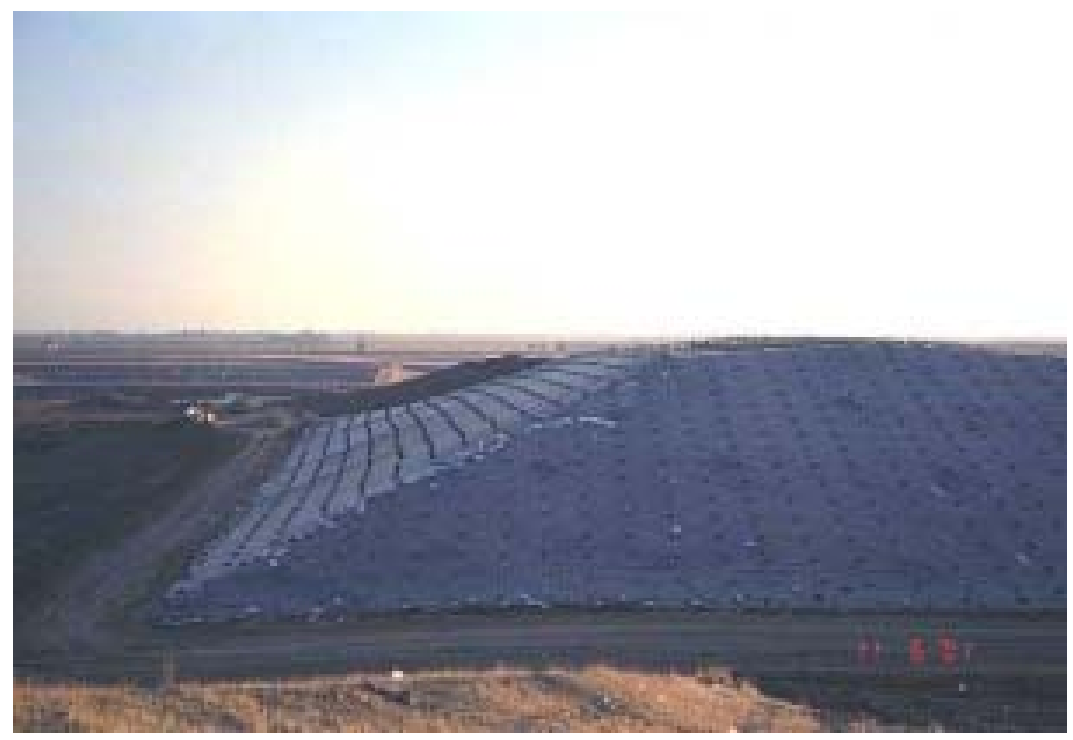

Image 3-3: Northeast anaerobic surface liner 
Based on Vector and County staff research, it was determined that a 36-mil reinforced polypropylene geomembrane (RPP) would be the preferred choice for an exposed geomembrane cover $^{1}$. Reinforced polypropylene offered distinct advantages over the other potential materials including long service life (a 20-year warrantee was obtained), superior strength due to the nylon reinforcement, and low thermal expansion and contraction.

To expedite construction and reduce the overall cost of the project, the County decided to directly purchase the necessary membrane material and provide it to the contractor for installation. On June 29, 2001, the County issued a request for quotes for 350,000 square feet of 36-mil RPP. Quotes were received on July 9, 2001 with the lowest priced quote received from Colorado Linings International (Colorado).

The plans and specifications for the installation of the RPP surface liner were issued for bid on June 15, 2001. Later that month, Addendum Number 1 was issued to include a majority of the leachate injection and gas collection piping. Bids were due on July 13, 2001; however, no bids were received. The County inquired to each of the plan holders and generally found that bids were not submitted because the liner companies could not locate a subcontractor to perform the earthwork.

The County reissued the plans and specifications on July 23, 2001 and allowed three separate bid options. Option A was the entire project. Option B was only the installation of the liner, and Option C was only the earthwork. Bids were received on August 6, 2001 with the selected contractor being Colorado Linings International. Because Colorado's winning bid was significantly higher than the engineer's estimate and the potential difficulties with excessive pressure buildup under the aerobic liner, the covering of the aerobic cell was eliminated (for further discussion refer to Section 5.1).

The installation of surface liner and associated piping was completed in November 2001.

\subsubsection{Monitoring}

Temperature, moisture, leachate quantity and quality, and LFG pressure and composition are monitored through an array of sensors placed within the waste and in the leachate collection and recovery system (LCRS). Each sensor location received a temperature sensor (thermistor), a linear low-density polyethylene (LLDPE) tube, and a moisture sensor (a PVC moisture sensor and in some cases a gypsum block). For protection, each wire and tube was encased in either a 1.25-inch HDPE pipe or run inside the LFG collection piping (Image 3-4). Refer to Appendix B, Details 3-2 through 3-5 for sensor location diagrams.

\footnotetext{
${ }^{1}$ Vector Engineering, "Design Report for the Surface Liners of the Module D Phase 1 Bioreactors at the Yolo County Central Landfill”, October 2001.
} 


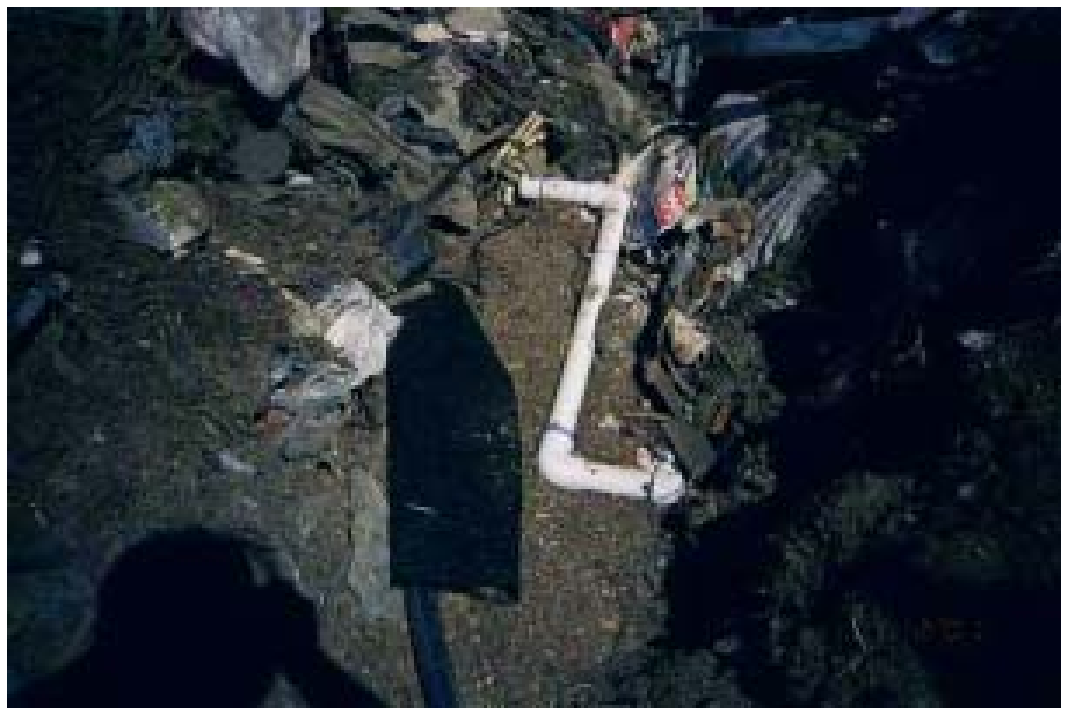

Image 3-4: Moisture, temperature, and tube

Sensors on instrumentation Layers 1, 2, and 3 were placed on either a bedding of greenwaste (shredded yard waste), wood chips (chipped wood waste), bin fines (fine pieces of greenwaste), or pea gravel to protect against damage from the underlying waste. Sensors installed on the primary liner (prior to any waste placement) were placed on geocomposite and covered with pea gravel prior to the placement of the chipped tire operations layer.

\subsubsection{Temperature}

Temperature is monitored with thermistors manufactured by Quality Thermistor, Inc. Thermistors with a temperature range of $0^{\circ} \mathrm{C}$ to $100^{\circ} \mathrm{C}$ were chosen to accommodate the temperature ranges expected in both the anaerobic and aerobic cells. To prevent corrosion, each thermistor was encased in epoxy and set in a stainless steel sleeve. All field wiring connections were made by first soldering the connection, then covering each solder joint with adhesive lined heat shrink tubing, and then encasing the joint in electrical epoxy. Changes in temperature are measured by the change in thermistor resistivity (ohms). As temperature increases, thermistor resistance decreases.

\subsubsection{Moisture}

Moisture levels are measured with polyvinyl chloride (PVC) moisture sensors and gypsum blocks. Both the PVC moisture sensors and gypsum blocks are read utilizing the same meter. The PVC sensors are perforated 2-inch-diameter PVC pipes with two stainless steel screws spaced 8 inches apart and attached to wires to form a circuit that includes the gravel filled pipe. The PVC sensors were designed by Yolo County and used successfully during the pilot scale project $^{2}$. The PVC moisture sensor can provide a general, qualitative assessment of the waste's

\footnotetext{
2 Yazdani, R., Moore, R. Dahl. K. and D. Augenstein 1998 Yolo County Controlled Landfill Bioreactor Project. Yolo County Public Works and I E M, Inc. Yolo County Public Works and I E M, Inc. report to the Urban Consortium Energy Foundation (UUCETF) and the Western Regional Biomass Energy Program, USDOE.
} 
moisture content. A reading of 0 to 40 equates to no free liquid, 40 to 80 equates to some free liquid, and 80 to 100 means completely saturated conditions.

The gypsum blocks are manufactured by Electronics Unlimited and are typically used for soil moisture determinations in agricultural applications. Gypsum blocks establish equilibrium with the media in which they are placed and are, therefore, reliable at tracking increases in the soil's moisture content. However, the gypsum block can take considerable time to dry and therefore may not reflect the drying of the surrounding environment.

\subsubsection{Leachate Quantity and Quality}

Leachate that is generated from the northeast anaerobic cell drains to the eastside Module D leachate collection sump (Image 3-5). A dedicated pump is then used to remove the leachate and pump it to one of the on-site leachate storage ponds. A flow meter measures rate and total volume pumped from the sump.

Leachate is monitored for the following field parameters: $\mathrm{pH}$, electrical conductivity, dissolved oxygen, oxidation-reduction potential, and temperature. The following parameters will be analyzed by a laboratory: dissolved solids, biochemical oxygen demand, chemical oxygen demand, organic carbon, nutrients $\left(\mathrm{NH}_{3}, \mathrm{TKN}, \mathrm{TP}\right)$, common ions, heavy metals and organic priority pollutants. For the first year, monitoring will be conducted monthly during the first six months and quarterly for the following six months. After the first year, monitoring will be conducted semi-annually $(\mathrm{pH}$, conductivity, and flow rate will continue to be monitored on a monthly basis as required by the State of California's Waste Discharge Requirements in Order 500-134).

\subsubsection{Pressure}

Pressure within the northeast anaerobic cell is monitored with $1 / 4$-inch inner diameter and $3 / 8^{-i n c h}$ outer diameter LLDPE sampling tubes. Each tube can be attached to a pressure gage and supplemental air source. By first purging the tube with the air source (to remove any liquid blockages), and then reading the pressure, an accurate gas and/or water pressure can be measured at each sensor location.

\subsubsection{Landfill Gas Composition and Flow}

Landfill gas composition and flow are measured from the pre-manufactured well heads utilizing a GEM-500 combustible gas meter, manufactured by LANDTEC. The GEM-500 is capable of measuring methane (either as a percent by volume or percent of the lower explosive limit), carbon dioxide, and oxygen. A reading for "balance" gas is also provided, which is assumed to be nitrogen. 


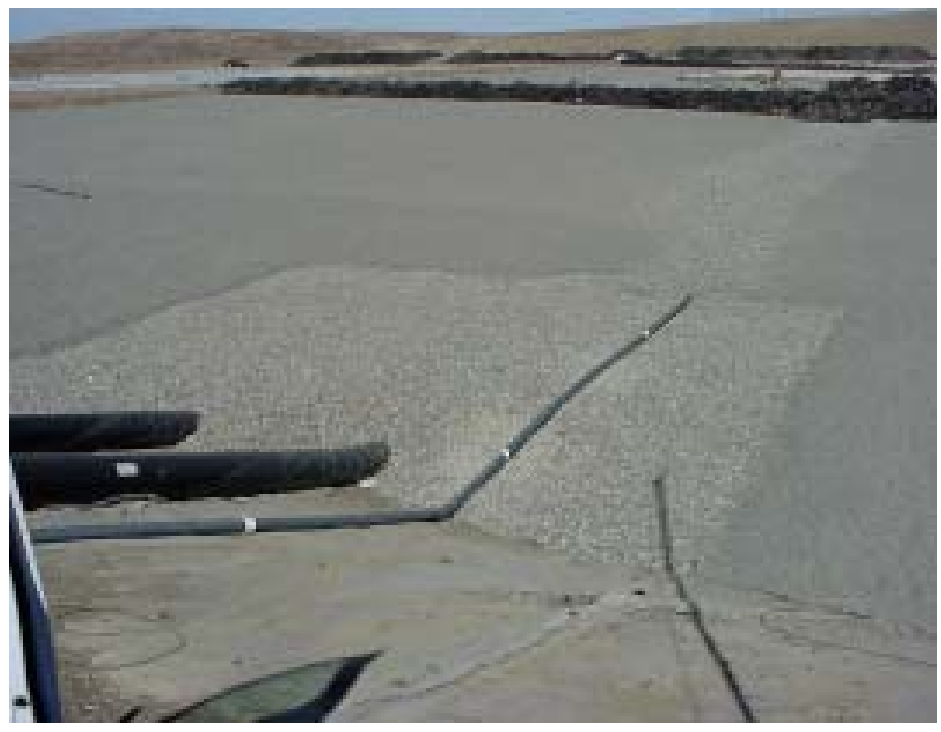

\section{Image 3-5: Gravel drainage layer and leachate collection sump}

\subsubsection{Waste Sampling}

Yolo County conducted the first waste sampling event for the northeast anaerobic cell on June 5, 2002. Waste was sampled to quantify the methane generation potential of the waste. Waste was drilled to an approximate depth of 50 feet with samples taken at 5-foot intervals. Waste will be sampled from the northeast anaerobic cell annually for the next two years to monitor the progress of waste decomposition and compare actual methane generation to laboratory methane generation.

\subsubsection{Surface Scan}

Under current federal guidelines (40 CFR 60.752), landfills exceeding a specific size must monitor for methane surface emissions and any reading in excess of 500 PPM (40 CFR 60.755 (c)) requires corrective action to be taken. The Yolo County Central Landfill is not currently required to test for methane surface emissions, however, as part of the FPA, the County has proposed to conduct quarterly surface scans to demonstrate the emissions (or lack of) from a controlled bioreactor landfill.

Surface emissions were monitored with a model OVA-108 Flame Ionization Detector (FID) instrument in March 2003. The OVA-108 is capable of detecting methane in the parts-permillion (PPM) range and has an accuracy of \pm 20 percent of reading. Surface emissions were previously monitored with a model TVA-1000 FID/Photo Ionization Detector (PID) instrument. Under the FID setting, the TVA-1000 is capable of detecting methane in the parts-per-million (PPM) range and has an accuracy of \pm 2.5 PPM or 25 percent of the reading, whichever is greater. In the event significant methane was detected, the unit could be switched to PID mode to detect volatile organic compounds (VOC). Methane surface concentrations are monitored along the perimeter of the collection area and along a pattern that transverses the landfill at 15 meter intervals. Due to high winds and inclement weather, the surface scan scheduled for December 2002 was postponed until January 2003. A summary of the surface scans performed on the northeast anaerobic cell is presented below in Table 3-4. 
Table 3-4. Summary of Surface Scans Performed on the Northeast Anaerobic Cell with Synthetic Surface Cover System

\begin{tabular}{|c|l|c|l|}
\hline $\begin{array}{c}\text { Surface } \\
\text { Scan No. }\end{array}$ & \multicolumn{1}{|c|}{ Date } & Max. Emissions Detected & Location of Max. Emissions \\
\hline 1 & April 3, 2002 & No fugitive emissions detected & Not Applicable \\
\hline 2 & June 6, 2002 & $9 \mathrm{ppm}$ & Southwest corner of the cell \\
\hline 3 & September 19, 2002 & $8 \mathrm{ppm}$ & Northwest corner of the cell \\
\hline 4 & January 7, 2003 & No fugitive emissions detected & Center north face of the cell \\
\hline 5 & March 19, 2003 & $70 \mathrm{ppm}$ & $\begin{array}{l}\text { Along the entire northern } \\
\text { perimeter of the cell. }\end{array}$ \\
\hline
\end{tabular}

The detection of surface emissions is most likely due to landfill operations in nearby areas. While background concentrations were monitored prior to conducting the surface scan (and in some cases following the surface scan), changes in wind currents could have transported methane from adjacent areas. During June 2002 and September 2002, grading and waste filling activities in the adjacent west-side 6-acre area could have promoted the detection of gas emissions in the northeast 3.5-acre cell. Additionally, activities from Module D Phase II construction (which involved exposing waste form an adjacent unit to facilitate base liner installation) could have promoted the detection of gas emissions during the September 2002 surface scan. The high surface emissions in March 2003 can be attributed to high background readings, ranging between 60 and $65 \mathrm{ppm}$, that may be due to Module D Phase II construction. Changing wind current during the surface scan could have also carried emissions from the west-side anaerobic cell where higher emissions have been measured due to leakage from small gaps in the surface liner (less than 1 inch) where piping exits the cell.

As presented in the table above, methane surface emissions from the northeast 3.5-acre cell are extremely low, and essentially negligible. There are two major items that are responsible for this effective control of surface emissions, they are: 1) The installation of a synthetic cover over the entire cell, and 2) The use of an active landfill gas extraction system. The synthetic membrane not only limits gas transfer from the surface of the cell, it allows the active gas collection system to be operated at higher vacuum rates (without drawing in excess oxygen) thus further limiting the possibility if surface emissions.

The true methane emissions detected are also a function of the accuracy of the surface scan equipment. The TVA-1000 FID instrument has an accuracy of \pm 25 percent of reading or $\pm 2.5 \mathrm{ppm}$, whichever is greater, from 1.0 to $10,000 \mathrm{ppm}$. Thus many of the surface emissions are outside (below) the accuracy range and thereby assumed to be negligible.

\subsubsection{Operation}

Operation of the northeast anaerobic cell as a bioreactor will began March 27, 2002 when supplemental liquid was first added to the cell.

\subsubsection{Leachate Recirculation}

Leachate addition to the northeast cell began on March 27, 2002 (Image 3-6). Each of the horizontal liquid injection lines was initially tested by pumping approximately 1000 gallons into the line to confirm operation and correlate flow versus pressure for each injection lateral. 


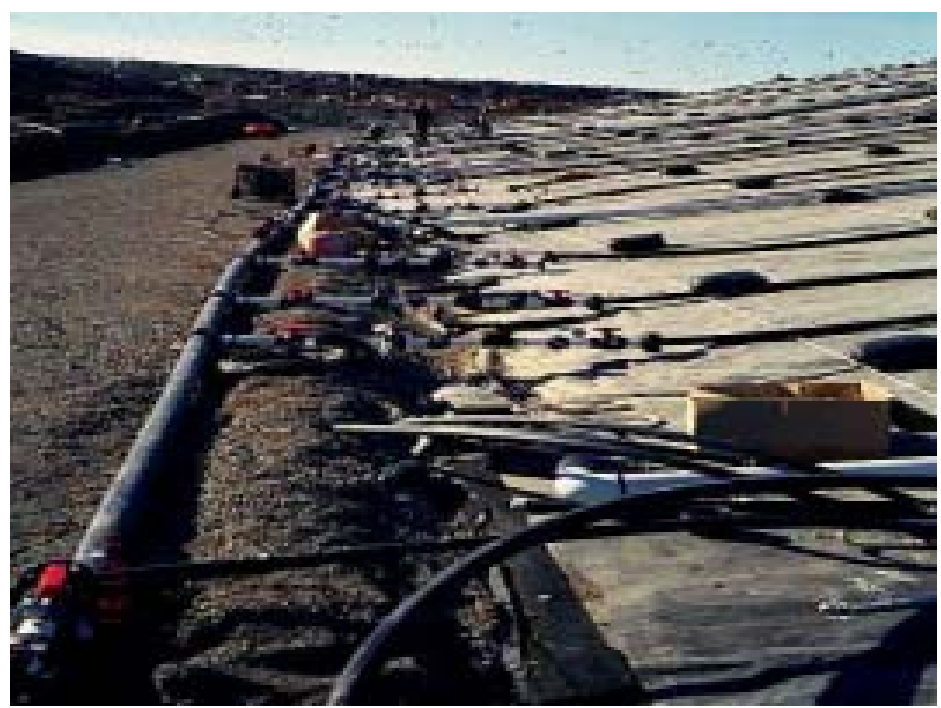

Image 3-6: Leachate injection header and laterals

With the initial testing phase complete, full-scale liquid addition has commenced. Once the waste reaches field capacity, only enough liquid to maintain field capacity will be added.

During August 2002, leachate injection was temporarily halted due to scale buildup in the injection laterals which was significantly reducing the flow in the injection lines. On September 11, 2002, approximately 3000 gallons of a citric acid solution ( $\mathrm{pH}$ approximately 4) was added to the injection laterals on the northeast anaerobic cell to dissolve the scale buildup. The citric acid was added to the injection laterals and allowed to set overnight (approximately 14 hours). Groundwater was then flushed through the lines to remove the citric acid and scaling residue.

Liquid injection resumed in the northeast cell on September 24, 2002. Approximately 1,563,042 gallons of supplemental liquid has been added and 548,462 gallons of leachate recirculated through the end of March 2003 with 48 percent added to Layer 1, 35 percent added to Layer 2, and 16 percent added to Layer 3 (Appendix C, Figure 3-1).

\subsubsection{Landfill Gas Collection}

Landfill gas collection began December 13, 2001 once the necessary piping was installed at the end of November 2001. Gas collection prior to leachate addition was necessary to prevent "billowing" or excess gas pressure under the surface liner.

\subsection{Results And Discussion}

Sensor names are represented numerically by the instrumentation layer in which the sensor is located, followed by the assigned sensor number. Layer 1 is represented by a 1 , Layer 2 is represented by a 2, and so forth. The complete name of the sensor is denoted by the layer number - the sensor number. For example, the second sensor on Layer 1 is named 1-02. 


\subsubsection{Temperature}

Temperature is monitored with thermistors manufactured by Quality Thermistor, Inc. Thermistors with a temperature range of $0^{\circ} \mathrm{C}$ to $100^{\circ} \mathrm{C}$ were chosen so they would be able to accommodate the temperature ranges expected in both the anaerobic and aerobic cells. Resistance was measured by the SCADA system located in the instrumentation shed starting in March 2002. Resistance was previously measured manually by connecting the sensor wires to a 26 III Multimeter manufactured by Fluke Corporation.

Temperature results are presented in Appendix C, Figures 3-2 to 3-4. Recent temperature fluctuations in Layer 3 correspond to the addition of cool water (approximately $70^{\circ} \mathrm{F}$ ) to the waste. Representative sensors that demonstrate the cooling trend during liquid injection and subsequent warming trend following liquid injection are provided in Appendix C, Figure 3-5. A summary of the results is presented below in Table 3-5 and Figure 3-6.

Table 3-5. Temperature Summary for the Northeast Anaerobic Cell

\begin{tabular}{|c|c|c|c|c|c|c|}
\hline & \multicolumn{2}{|c|}{$\begin{array}{c}\text { Previous Reporting Period } \\
(\mathbf{1 0 / 1 / 0 2} \text { to12/31/02) }\end{array}$} & \multicolumn{3}{c|}{$\begin{array}{c}\text { Current Reporting Period } \\
(\mathbf{1 / 1 / 0 3} \text { to 3/31/03) }\end{array}$} \\
\hline Layer & $\begin{array}{c}\text { Minimum } \\
\text { Temp. }\left({ }^{\circ} \mathbf{C}\right)\end{array}$ & $\begin{array}{c}\text { Maximum } \\
\text { Temp. }\left({ }^{\circ} \mathbf{C}\right)\end{array}$ & $\begin{array}{c}\text { Average } \\
\text { Temp. }\left({ }^{\circ} \mathbf{C}\right)\end{array}$ & $\begin{array}{c}\text { Minimum } \\
\text { Temp. }\left({ }^{\circ} \mathbf{C}\right)\end{array}$ & $\begin{array}{c}\text { Maximum } \\
\text { Temp. }\left({ }^{\circ} \mathbf{C}\right)\end{array}$ & $\begin{array}{c}\text { Average } \\
\text { Temp. }\left({ }^{\circ} \mathbf{C}\right)\end{array}$ \\
\hline 1 & 23.4 & 48.2 & 38.4 & 29.5 & 55.1 & 40.3 \\
\hline 2 & 32.6 & 62.9 & 51.2 & 38.3 & 57.1 & 47.7 \\
\hline 3 & 33.3 & 63.3 & 50.4 & 7.6 & 67.6 & 43.1 \\
\hline
\end{tabular}

Figure 3-6. Average Temperatures for the Northeast Anaerobic Cell

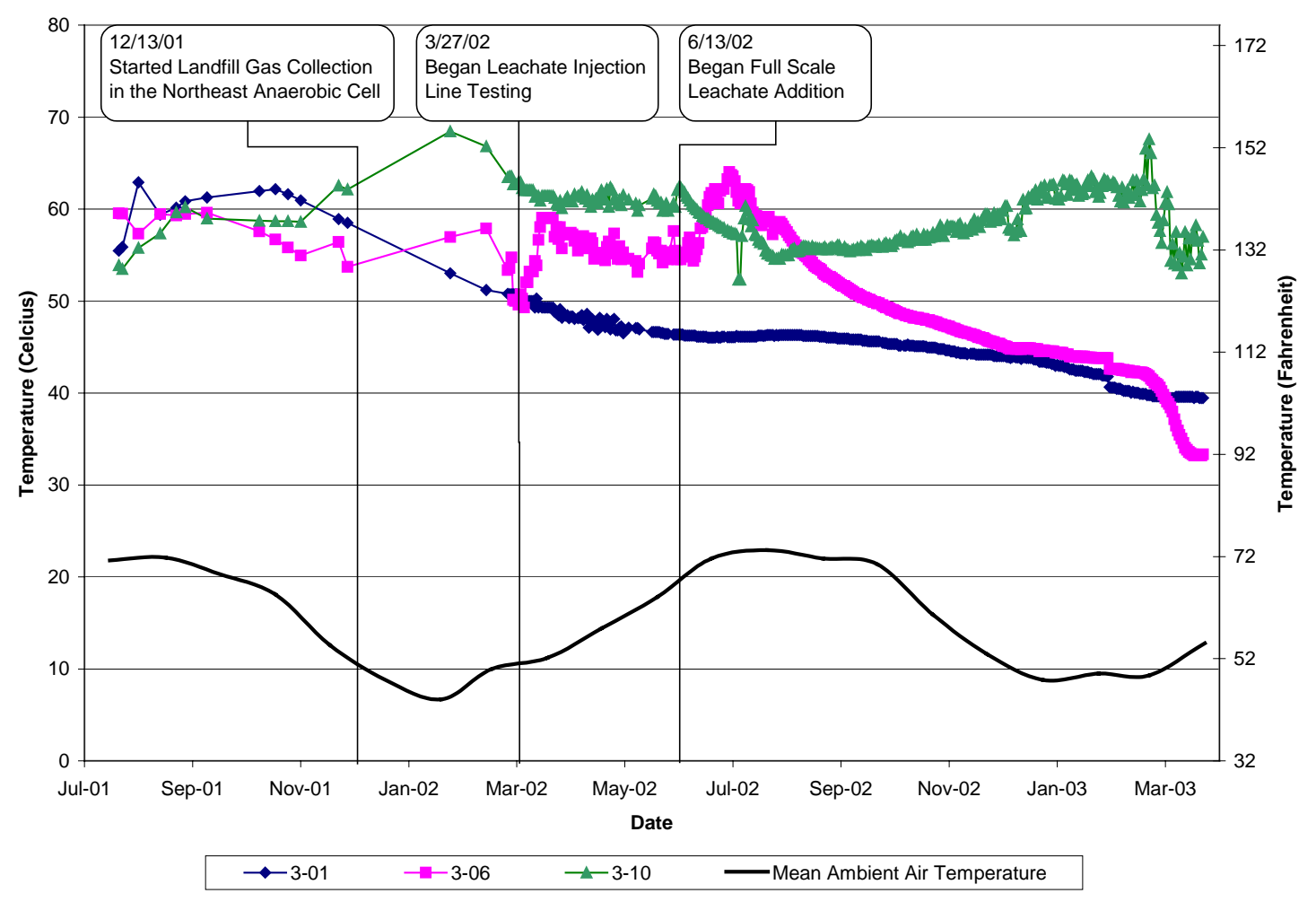




\subsubsection{Moisture}

The SCADA system started electronically measuring moisture in March 2002. Moisture was previously measured manually with a Model MM 4 moisture meter manufactured by Electronics Unlimited. During the pilot scale project, Yolo County conducted laboratory tests with the PVC sensors to determine the relationship between the multimeter readings and the presence of free liquid in the PVC sensor. It was determined that a meter reading of less than 40 corresponded to an absence of free liquid. A reading between 40 and 80 corresponds to the presence of free liquid in the PVC pipe but less than saturated conditions. Readings of greater than 80 indicate saturated conditions; i.e. the PVC sensor is full of liquid.

Moisture results are presented in Appendix C, Figures 3-7 to 3-11. Since the start of full-scale liquid addition in June 2002, the average moisture levels in Layer 1 and Layer 2 have increased to moisture levels in the some free liquid zone and completely saturated zone. In Layer 3, fullscale liquid addition commenced in February 2003 and moisture levels increased to the some free liquid zone. A summary of the results is presented below in Table 3-6 and Figure 3-12.

Table 3-6. PVC Moisture Summary for the Northeast Anaerobic Cell

\begin{tabular}{|c|c|c|c|c|c|c|}
\hline & \multicolumn{3}{|c|}{$\begin{array}{c}\text { Previous Reporting Period } \\
(\mathbf{1 0 / 1 / 0 2} \text { to12/31/02) }\end{array}$} & \multicolumn{3}{c|}{$\begin{array}{c}\text { Current Reporting Period } \\
(\mathbf{1 / 1 / 0 3} \text { to 3/31/03) }\end{array}$} \\
\hline Layer & $\begin{array}{c}\text { Minimum } \\
\text { Moisture }\end{array}$ & $\begin{array}{c}\text { Maximum } \\
\text { Moisture }\end{array}$ & $\begin{array}{c}\text { Average } \\
\text { Moisture }\end{array}$ & $\begin{array}{c}\text { Minimum } \\
\text { Moisture }\end{array}$ & $\begin{array}{c}\text { Maximum } \\
\text { Moisture }\end{array}$ & $\begin{array}{c}\text { Average } \\
\text { Moisture }\end{array}$ \\
\hline 1 & 1.9 & 94.8 & 66.9 & 6.0 & 94.8 & 71.5 \\
\hline 2 & 2.8 & 94.8 & 61.9 & 5.4 & 94.8 & 82.4 \\
\hline 3 & 1.9 & 91.3 & 25.3 & 4.9 & 94.8 & 39.8 \\
\hline
\end{tabular}


Figure 3-12. Average Moisture Levels for the Northeast Anaerobic Cell

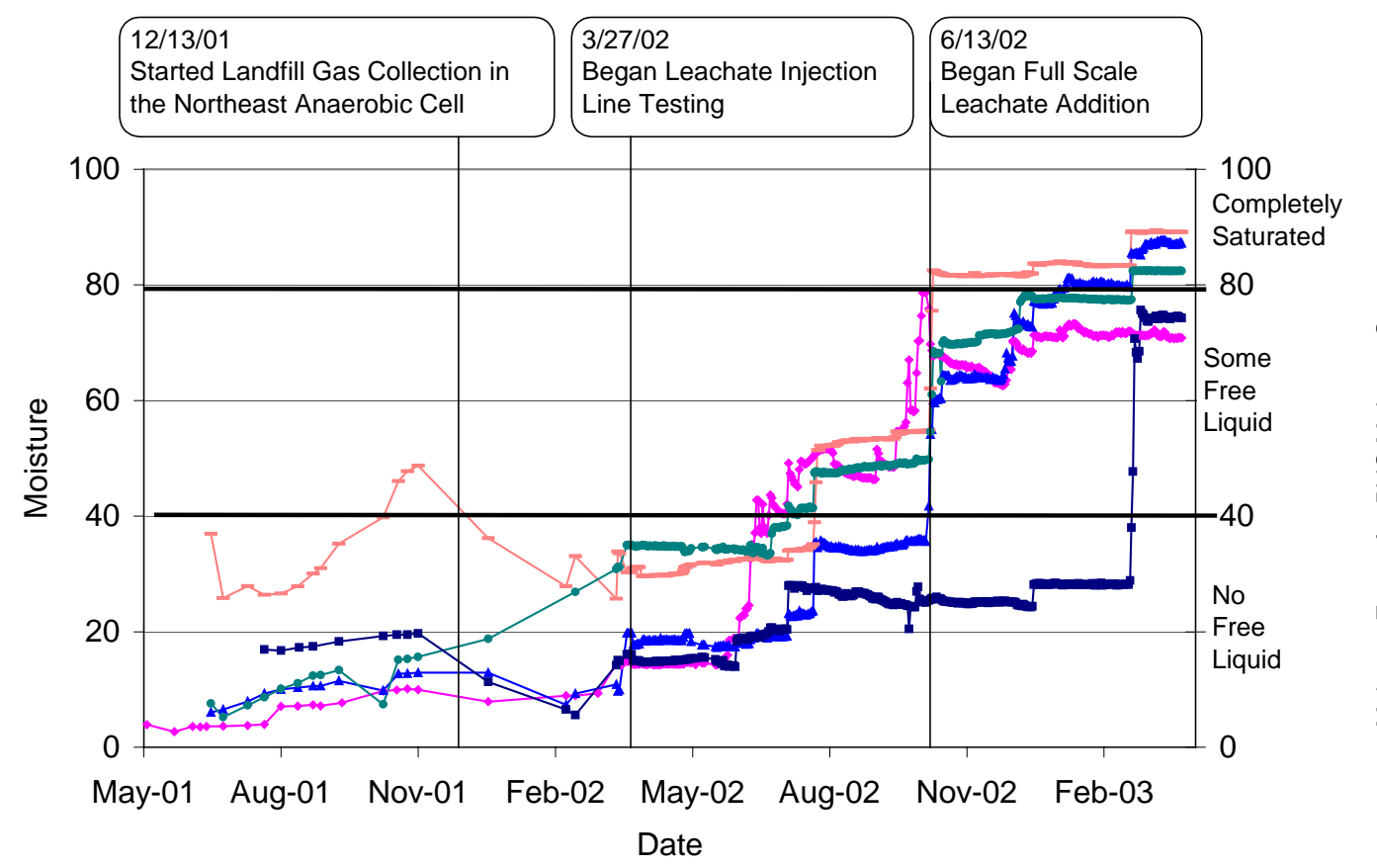

$\rightarrow$ Layer 1 PVC Moisture Sensors

- Layer 2 Gypsum in Plaster Moisture Sensors

- Layer 3 PVC Moisture Sensors

\subsubsection{Landfill Gas Collection System}

Gas composition is measured from the wellheads located on top of the northeast anaerobic cell with the GEM-500. Gas flow is measured by differential pressures at the well heads with a DWYER Instruments, Inc., "Magnehelic" pressure gage. A thermal mass flow meter installed in the main header pipeline near the instrumentation shed records flow rate and total for all of the northeast cell. The meter is equipped with two separate calibration curves (for different gas constituent concentrations) and automatically corrects for temperature and pressure and records in standard cubic feet.

Gas collection lines are represented numerically by the layer the line is located, followed by a "G" and the number that denotes the line on a specific layer. For example, the first gas collection line on layer 3 is denoted 3-G1.

Landfill gas results are presented in Appendix C, Figures 3-13 to 3-16. Methane concentrations from the wellheads fluctuate based on the applied vacuum, barometric pressure, and the status of waste decomposition. In June 2002, the increase in oxygen and balance concentrations and the decline in methane and carbon dioxide concentrations can be attributed to the increase in vacuum applied to the gas collection system. In order to reduce landfill gas emissions while drilling for waste samples, the vacuum applied to the gas extraction system was increased resulting in air intrusion into the northeast anaerobic cell. Subsequently, a leak in the gas collection header line was discovered resulting in air intrusion into the gas collection system. A summary of the results is presented below in Table 3-7. 
Table 3-7. Landfill Gas Summary for the Northeast Anaerobic Cell

\begin{tabular}{|l|l|l|l|}
\hline Parameter & Results \\
\hline $\begin{array}{l}\text { Cumulative Methane from } \\
\text { December 16, 2001 to March 31, 2003 }\end{array}$ & $\begin{array}{l}\text { 22.3 } \\
\text { (which 10 is equivalent to approximately 3500 } \\
\text { barrels of oil) }\end{array}$ \\
\hline LFG Flow Rate for the period of & Minimum & Maximum & Average \\
\cline { 2 - 5 } January 1, 2003 through March 31, 2003 & $114.7 \mathrm{scf}$ & $171.6 \mathrm{scf}$ & $144.3 \mathrm{scf}$ \\
\hline $\begin{array}{l}\text { Methane Concentration for the period of } \\
\text { January 1, 2003 through March 31, 2003 }\end{array}$ & Minimum & Maximum & Average \\
\cline { 2 - 5 } & $44.4 \%$ & $53.5 \%$ & $49.2 \%$ \\
\hline
\end{tabular}

Landfill gas from the northeast cell was sampled in March 2003 and sent to an independent laboratory for analytical testing. Analytical results are presented in Appendix D, Table 3-8. Analytical results show lower methane levels at 390,000 parts per million (ppm) than methane levels detected in the field in March 2003. Higher methane levels read in the field could be due to the inclusion of other gases, such as hydrocarbons, that would be recorded as methane by the GEM. Results also show a general decline in volatile organic compounds (VOC) since the start of liquid injection as presented below in Figure 3-17.

Figure 3-17. Change in VOC Concentrations since May 2002.

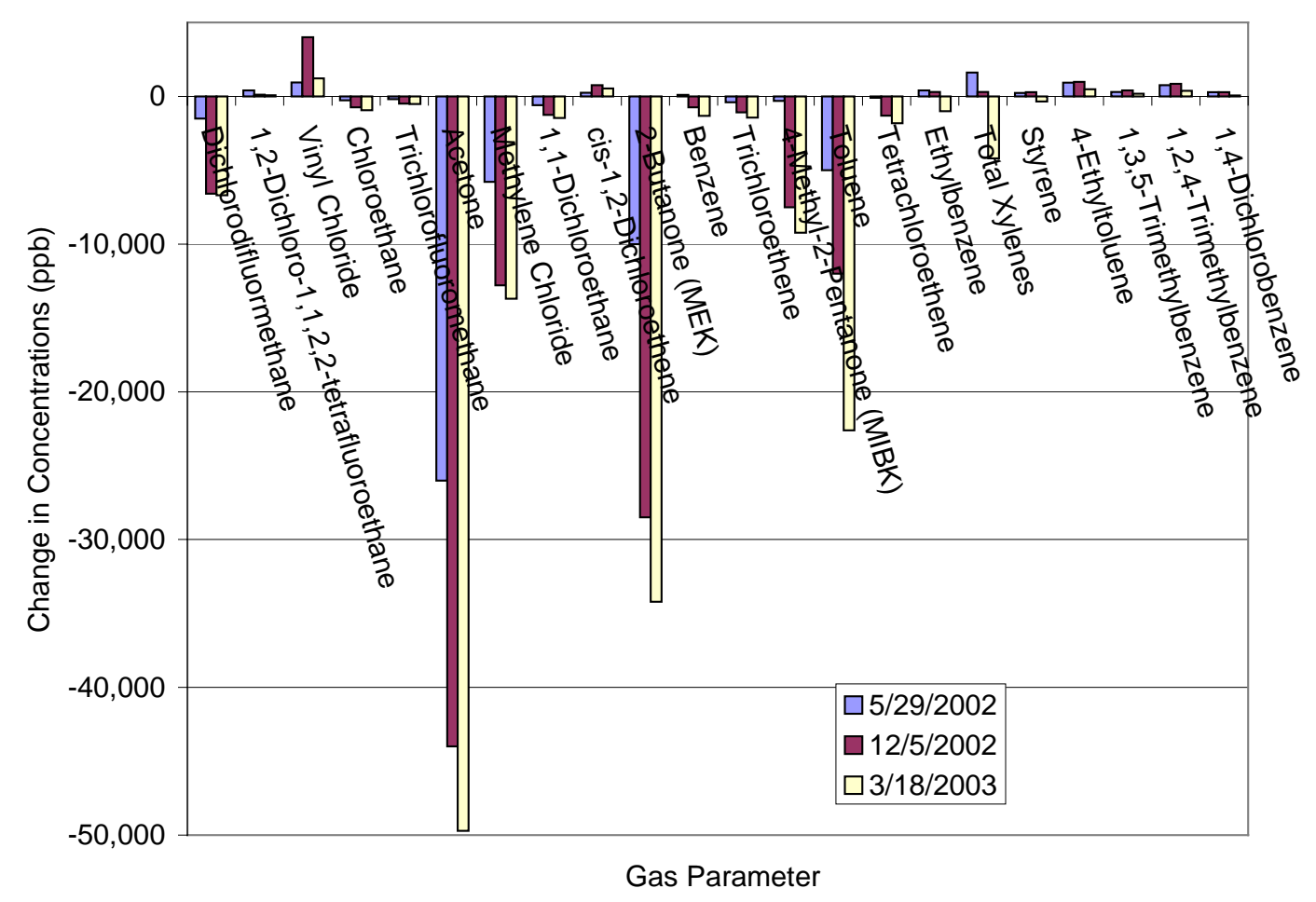




\subsubsection{Leachate Quantity And Quality}

After July 24, 2002, all leachate generated was recirculated back to the northeast anaerobic cell with the exception of 35,460 gallons of leachate removed during injection line cleaning between September 24, 2002 and October 4, 2002. Approximately 1,563,042 gallons of supplemental liquid has been added and 548,462 gallons of leachate has been recirculated to the northeast anaerobic cell since June 2002 (Appendix C, Figure 3-1).

Leachate was sampled for analytical testing on a monthly basis from May 2002 to October 2002 and thereafter was sampled on a quarterly basis. Analytical results are presented in Appendix E, Table 3-9. Field chemistry and selected analytical results are presented below in Table 3-10.

\section{Table 3-10. Field Chemistry and Selected Laboratory Chemistry for Leachate Sampled} from the Northeast Anaerobic Cell

\begin{tabular}{|l|c|c|c|c|c|c|c|c|}
\hline PARAMETER & Date: & $\mathbf{2 / 1 4 / 2 0 0 2}$ & $\mathbf{5 / 1 4 / 2 0 0 2}$ & $\mathbf{6 / 2 0 / 2 0 0 2}$ & $\mathbf{7 / 2 3 / 2 0 0 2}$ & $\mathbf{9 / 2 6 / 2 0 0 2}$ & $\mathbf{1 0 / 1 7 / 2 0 0 2}$ & $\mathbf{2 / 2 6 / 2 0 0 3}$ \\
\hline Field Parameters: & $\mathrm{Units}$ & & & & & & & \\
\hline $\mathrm{PH}$ & & 7.13 & 7.40 & 7.60 & 7.44 & 7.47 & 7.35 & 8.16 \\
\hline Electrical Conductivity & $\mathrm{\mu S}$ & 6583 & 6095 & 4054 & 11510 & 12440 & 10230 & 9351 \\
\hline $\begin{array}{l}\text { Oxidation Reduction } \\
\text { Potential }\end{array}$ & $\mathrm{mV}$ & -119 & 80 & 94 & -7 & -35 & -25 & 160 \\
\hline Temperature & $\mathrm{C}$ & 19.9 & 25.9 & 26.5 & 30.5 & 28.4 & 26.0 & 23.5 \\
\hline Dissolved Oxygen & $\mathrm{mg} / \mathrm{L}$ & 0.65 & 1.4 & 2.04 & 0.33 & 3.66 & 2.96 & 6 \\
\hline Total Dissolved Solids & $\mathrm{ppm}$ & 5244 & 4059 & 3062 & 9740 & 10770 & 8640 & 7850 \\
\hline General Chemistry: & & & & & & & & \\
\hline Bicarbonate Alkalinity & $\mathrm{mg} / \mathrm{L}$ & 1740 & 1760 & 1110 & 3740 & 3960 & 4010 & 2680 \\
\hline Total Alkalinity as CO & $\mathrm{mg} / \mathrm{L}$ & 1740 & 1760 & 1110 & 3740 & 3960 & 4010 & 2680 \\
\hline BOD & $\mathrm{mg} \mathrm{O} / \mathrm{L}$ & 20 & 19 & 10 & 200 & 1400 & 3000 & 44 \\
\hline Chemical Oxygen Demand & $\mathrm{mg} \mathrm{O} / \mathrm{L}$ & 633 & 791 & 196 & 1620 & 2830 & 1810 & 120 \\
\hline Chloride & $\mathrm{mg} / \mathrm{L}$ & 1070 & 1030 & 617 & 1950 & 1870 & 1380 & 1470 \\
\hline Ammonia as N & $\mathrm{mg} / \mathrm{L}$ & 30 & 26.3 & 13.5 & 131 & 255 & 289 & 132 \\
\hline Nitrate-Nitrite as N & $\mathrm{mg} / \mathrm{L}$ & $<0.03$ & $<1.5$ & $<0.015$ & 0.061 & 1.4 & $<0.009$ & 17.3 \\
\hline Total Kjeldahl Nitrogen & $\mathrm{mg} / \mathrm{L}$ & 53.1 & 40 & 21.8 & 201 & 326 & 358 & 222 \\
\hline $\begin{array}{l}\text { Total Dissolved Solids } \\
\text { @ 180 C }\end{array}$ & $\mathrm{mg} / \mathrm{L}$ & 4440 & 3700 & 2500 & 7800 & 8000 & 6680 & 5720 \\
\hline $\begin{array}{l}\text { Total (Non-Volatile) } \\
\text { Organic Carbon }\end{array}$ & $\mathrm{mg} / \mathrm{L}$ & 202 & 123 & 68.8 & 544 & 943 & 588 & 325 \\
\hline Total Sulfide & $\mathrm{mg} / \mathrm{L}$ & 1.3 & 1.3 & 0.74 & 1.2 & 1.1 & 1.4 & 0.034 (tr) \\
\hline Dissolved Iron & $\mathrm{mg} / \mathrm{L}$ & 1.1 & 0.39 & 0.19 & $2.9 *$ & 3.9 & 4 & 2.5 \\
\hline Dissolved Magnesium & $\mathrm{mg} / \mathrm{L}$ & 323 & 262 & $\mathrm{NA}$ & 535 & 480 & 437 & 359 \\
\hline Dissolved Potassium & $\mathrm{mg} / \mathrm{L}$ & 152 & 133 & $\mathrm{NA}$ & 215 & 319 & 348 & 371 \\
\hline
\end{tabular}

Analytical results from the February sampling event indicate a dramatic decrease in BOD and $\mathrm{COD}$ and an increase in nitrate. It is unclear what has caused this dramatic change but one possible explanation would be dilution form recently injected leachate, this however is not supported by leachate pumping records (See Figure 3-1) which indicate relatively constant recirculation rates since December 2002. Follow-up monitoring will be performed to confirm these readings. 


\section{WEST-SIDE ANAEROBIC CELL}

The west-side anaerobic cell is located on the western 6 acres of Phase 1, Module D. Filling in the west-side anaerobic cell was complete in August 2002 with a total of 166,294 tons of waste placed.

\subsection{Experimental}

The experimental methods utilized are grouped into three categories: construction, monitoring, and operation. Each of these categories is discussed below.

\subsubsection{Construction}

Construction of the west-side anaerobic cell can be generally broken down into four major tasks: waste placement, liquid addition, gas collection, and surface liner installation. Each of these four tasks is discussed below. A summary of current monitoring data for the west-side anaerobic cell is provided in Appendix A, Table 4-1.

\subsubsection{Waste Placement}

Waste placement began on March 8, 2001 and was completed on August 31, 2002. Waste was placed in four lifts of approximately 15-foot thickness with 2.5:1 side slopes on interior slopes and 3:1 on exterior slopes (Detail 4-1, Image 4-1). All waste received at the landfill was deposited in the west-side cell (i.e. no class of waste was excluded). The use of daily cover soil during waste filling was minimized to aid in the overall permeability of the waste. Whenever possible, greenwaste or tarps were used as alternative daily cover (ADC) and, in the event soil was placed (for example, access roads or tipping pad), the soil was removed prior to placing the next lift of waste. Instrumentation Layers 1, 2, and 3 were placed between lifts, and base layer instrumentation was installed on the Module $6 \mathrm{D}$ base liner.

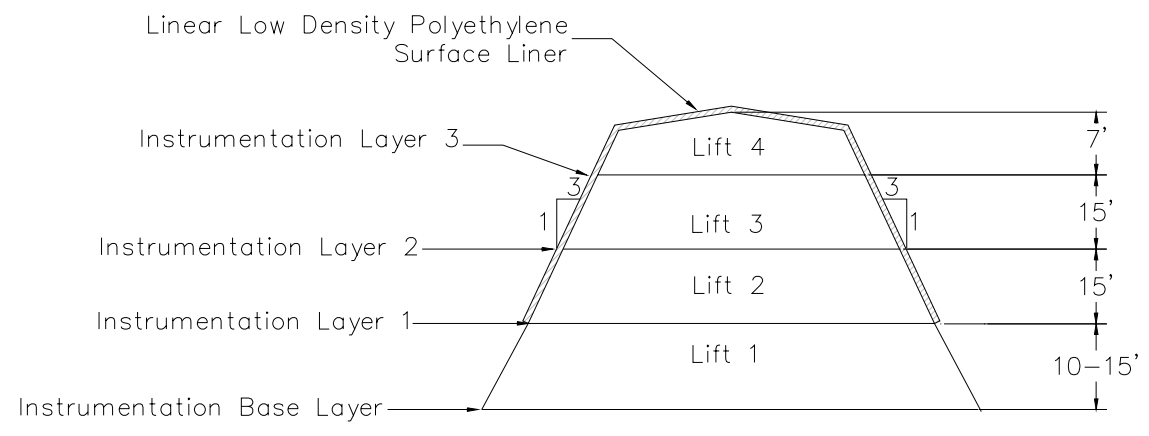

Detail 4-1. Cross Section of West-Side Anaerobic Cell 


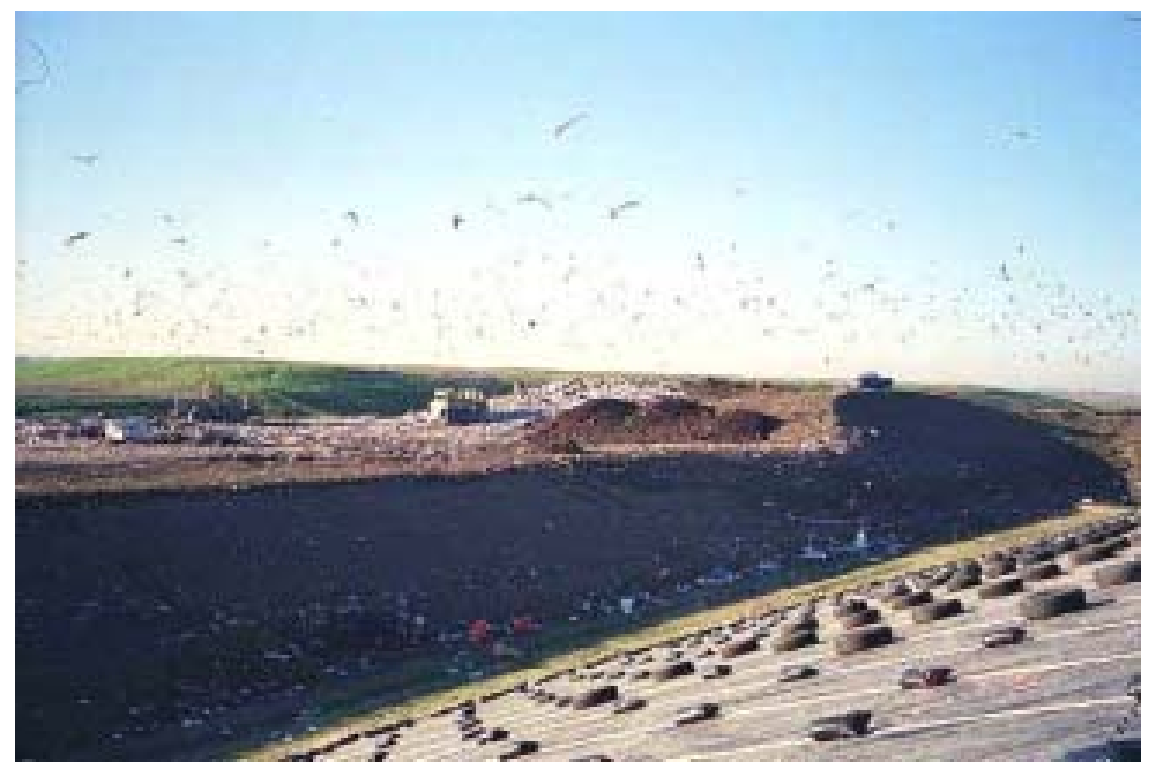

Image 4-1: Waste placement in the west-side cell

\subsubsection{Liquid Addition}

Horizontal liquid injection lines were installed between lifts 2 and 3, and 3 and 4 approximately every 40 feet. In addition, three injection lines were installed on top of lift 4, spaced every 25 feet. Each injection line consists of a 1.25-inch-diameter high-density polyethylene (HDPE) pipe placed horizontally (east to west), which extends completely through the waste. Each injection line was perforated by drilling a $1 / 8$ or $3 / 32$-inch hole every 10 or 20 feet (depending on which line). A total of 7,185 feet of injection piping was installed with a total of 321 injection holes.

Each of the injection laterals will be connected to a 4-inch-diameter HDPE injection header. Leachate injection for each lateral will be monitored and controlled by individual solenoid valves connected to the SCADA system. A flow meter will monitor the total volume and injection flow rate for the entire northeast anaerobic cell.

\subsubsection{Gas Collection}

Horizontal landfill gas (LFG) collection lines were installed between lifts 2 and 3 , and 3 and 4 , and on top of lift 4 . The LFG collection lines consist of various combinations of alternating 4 and 6-inch diameter schedule 80 and schedule 40 polyvinyl chloride (PVC) pipe as well as several variations of corrugated metal pipe and electrical conduit. At each line, shredded tires were used as the permeable media. A total of eighteen LFG collection lines were installed. A summary of gas collection lines for the northeast anaerobic cell is provided in Appendix A, Table 4-2.

Each LFG collection line is connected to a 6-inch or 8-inch diameter LFG collection header that conveys the gas to the on-site LFG-to-energy facility. Each LFG collection line incorporates a valve capable of controlling flow and a port for monitoring gas composition, temperature, pressure, and flow rate. 


\subsubsection{Surface Liner}

Vector was retained to provide design, plans and specifications for a surface lining system (refer to section 3.1.1.4). In contrast to the northeast anaerobic cell, which utilized a reinforced polypropylene membrane (RPP), a 40-mil linear low-density (LLDPE) geomembrane material was selected because it offered a greatly reduced cost. The installation of the surface liner was completed in October 2002 (Image 4-2).

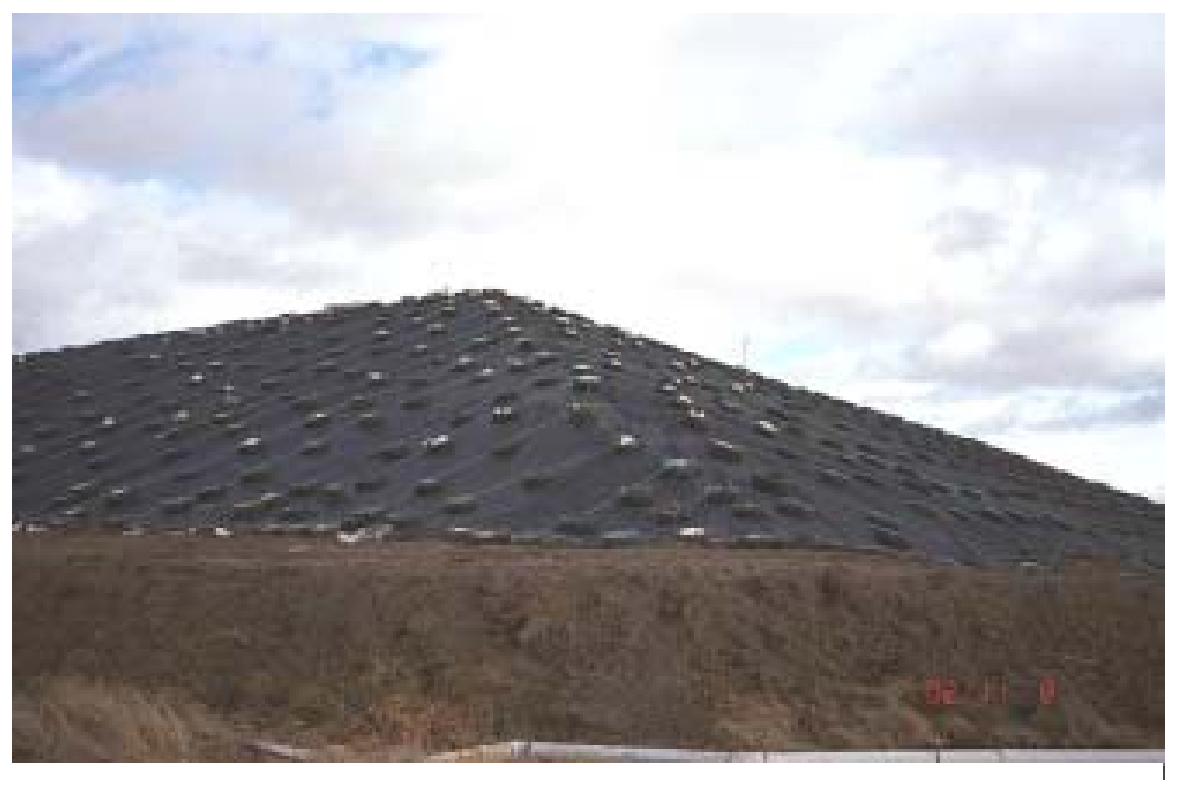

Image 4-2: West-side anaerobic cell surface liner.

\subsubsection{Monitoring}

Temperature, moisture, leachate quantity and quality, and LFG pressure and composition are monitored through an array of sensors placed within the waste and in the leachate collection and recovery system (LCRS). Each sensor location received a temperature sensor (thermistor), a linear low-density polyethylene (LLDPE) tube, and a moisture sensor (a PVC moisture sensor and in some cases a gypsum block). For protection, each wire and tube was encased in either a 1.25-inch HDPE pipe or run inside the LFG collection piping. Refer to Appendix B, Details 4-2 through 4-4 for sensor location diagrams.

\subsubsection{Temperature}

Temperature is monitored with thermistors manufactured by Quality Thermistor, Inc. Thermistors with a temperature range of $0^{\circ} \mathrm{C}$ to $100^{\circ} \mathrm{C}$ were chosen to accommodate the temperature ranges expected in both the anaerobic and aerobic cells. To prevent corrosion, each thermistor was encased in epoxy and set in a stainless steel sleeve. All field wiring connections were made by first soldering the connection, then covering each solder joint with adhesive-lined heat shrink tubing, and then encasing the joint in electrical epoxy. Changes in temperature are 
measured by the change in thermistor resistivity (ohms). As temperature increases, thermistor resistance decreases.

\subsubsection{Moisture}

Moisture levels are measured with polyvinyl chloride (PVC) moisture sensors and gypsum blocks. Both the PVC moisture sensors and gypsum blocks are read utilizing the same meter. The PVC sensors are perforated 2-inch-diameter PVC pipes with two stainless steel screws spaced 8 inches apart and attached to wires to form a circuit that includes the gravel filled pipe. The PVC sensors were designed by Yolo County and used successfully during the pilot scale project. The PVC moisture sensor can provide a general, qualitative assessment of the waste's moisture content. A reading of 0 to 40 equates to no free liquid, 40 to 80 equates to some free liquid, and 80 to 100 means completely saturated conditions.

\subsubsection{Leachate Quantity and Quality}

Leachate that is generated from the west-side anaerobic cell drains to the west-side Module D leachate collection sump. A dedicated pump is then used to remove the leachate and pump it to one of the on-site leachate storage ponds. A flow meter measures rate and total volume pumped from the sump.

Leachate is monitored for the following field parameters: $\mathrm{pH}$, electrical conductivity, dissolved oxygen, oxidation-reduction potential, and temperature. When leachate is generated in sufficient quantities, the following parameters will be analyzed by a laboratory: dissolved solids, biochemical oxygen demand, chemical oxygen demand, organic carbon, nutrients $\left(\mathrm{NH}_{3}, \mathrm{TKN}\right.$, $\mathrm{TP}$ ), common ions, heavy metals and organic priority pollutants. For the first year of liquid injection, monitoring will be conducted monthly for the first six months and quarterly for the following six months. After the first year, monitoring will be conducted semi-annually $(\mathrm{pH}$, conductivity, and flow rate will continue to be monitored on a monthly basis as required by the State of California's Waste Discharge Requirements in Order 5-00-134).

\subsubsection{Pressure}

Pressure within the northeast anaerobic cell is monitored with $1 / 4$-inch inner diameter and $3 / 8$-inch outer diameter LLDPE sampling tubes. Each tube can be attached to a pressure gage and supplemental air source. By first purging the tube with the air source (to remove any liquid blockages) and then reading the pressure, an accurate gas and/or water pressure can be measured at each sensor location.

\subsubsection{Landfill Gas Composition and Flow}

Landfill gas composition and flow are measured from the well heads utilizing a GEM-500 combustible gas meter, manufactured by LANDTEC, in combination with a 1/8-inch diameter pitot tube, manufactured by DWYER Instruments, Inc.. The GEM-500 is capable of measuring methane (either as a percent by volume or percent of the lower explosive limit), carbon dioxide, and oxygen. A reading for "balance" gas is also provided, which is assumed to be nitrogen. Currently, gas composition is analyzed from the same sampling tubes used to measure pressure.

\subsubsection{Waste Sampling}

Yolo County conducted the first waste sampling event for the west-side anaerobic cell on June 5, 2002. Waste was sampled to quantify the methane generation potential of the waste. Waste was drilled to an approximate depth of 35 feet with samples taken at approximately 5 feet intervals. 
Waste will be sampled from the west-side anaerobic cell annually for the next two years to monitor the progress of waste decomposition and compare actual methane generation to laboratory methane generation.

\subsubsection{Surface Scan}

Under current federal guidelines (40 CFR 60.752), landfills exceeding a specific size must monitor for methane surface emissions and any reading in excess of 500 PPM (40 CFR 60.755 (c)) requires corrective action to be taken. The Yolo County Central Landfill is not currently required to test for methane surface emissions, however, as part of the FPA, the County has proposed to conduct quarterly surface scans to demonstrate the emissions (or lack of) from a controlled bioreactor landfill.

Surface emissions were monitored with a model OVA-108 Flame Ionization Detector (FID) instrument in March 2003. The OVA-108 is capable of detecting methane in the parts-permillion (PPM) range and has an accuracy of \pm 20 percent of reading. Surface emissions were previously monitored with a model TVA-1000 FID/Photo Ionization Detector (PID) instrument. Under the FID setting, the TVA-1000 is capable of detecting methane in the parts-per-million (PPM) range and has an accuracy of \pm 2.5 PPM or 25 percent of the reading, whichever is greater. In the event significant methane was detected, the unit could be switched to PID mode to detect volatile organic compounds (VOC). Methane surface concentrations are monitored along the perimeter of the collection area and along a pattern that transverses the landfill at 15 meter intervals. Due to high winds and inclement weather, the surface scan scheduled for December 2002 was postponed until January 2003. A summary of the surface scans performed on the west-side anaerobic cell is presented below in Table 4-3.

Table 4-3. Summary of Surface Scans Performed on the West-Side Anaerobic Cell

\begin{tabular}{|c|l|c|l|}
\hline $\begin{array}{c}\text { Surface } \\
\text { Scan No. }\end{array}$ & \multicolumn{1}{|c|}{ Date } & $\begin{array}{c}\text { Max. Emissions } \\
\text { Detected }\end{array}$ & \multicolumn{1}{|c|}{ Location of Max. Emissions } \\
\hline 1 & April 3, 2002 & $50 \mathrm{ppm}$ & Southwest corner of the cell \\
\hline 2 & June 6, 2002 & $37 \mathrm{ppm}$ & $\begin{array}{l}\text { On top the cell, along the access road leading } \\
\text { to the active waste placement area }\end{array}$ \\
\hline 3 & September 19, 2002 & $124 \mathrm{ppm}$ & $\begin{array}{l}\text { Southwest corner of the cell. This area was } \\
\text { rescanned and surface concentrations } \\
\text { decreased to approximately 10 ppm. }\end{array}$ \\
\hline 4 & January 8, 2003 & $30 \mathrm{ppm}$ & $\begin{array}{l}\text { Along the northern perimeter near piping } \\
\text { from the leachate collection and removal } \\
\text { system (LCRS). }\end{array}$ \\
\hline 5 & March 19,2003 & $150 \mathrm{ppm}$ & $\begin{array}{l}\text { Detected at three locations: (1) The northern } \\
\text { perimeter of the cell near the LCRS piping, } \\
\text { (2) the north face of the cell directly south of } \\
\text { the perimeter and approximately 15 feet east } \\
\text { of the LCRS piping, and (3) directly south of } \\
\text { the top deck hinge point and approximately 15 } \\
\text { feet west of the centerline of the cell. }\end{array}$ \\
\hline
\end{tabular}


Because the west-side cell was still undergoing active waste placement and a membrane cover had not been installed prior to the April 2002, June 2002 and September 2002 surface scans, greater methane emissions were detected from the west-side cell than from the northeast anaerobic cell. The detection of high surface emissions in March 2003 may be due to high background readings (between 60 and $75 \mathrm{ppm}$ ) and unsealed areas (less than 1 inch) where piping penetrates the surface liner. A follow-up surface scan will be performed in April 2003 to confirm these readings and steps will be taken to seal the pipe penetrations.

\subsubsection{Operation}

Operation of the west-side anaerobic cell will begin once the leachate recirculation system and SCADA control systems are complete.

\subsubsection{Leachate Recirculation}

Initially, large volumes of liquid will be added to bring the waste to field capacity. Once field capacity has been reached, only enough liquid to maintain field capacity will be added.

\subsubsection{Landfill Gas Collection}

Landfill gas collection began May 7, 2002, once the necessary piping was installed. Gas collection prior to leachate addition was necessary to prevent "billowing" or excess gas pressure under the surface liner.

\subsection{Results And Discussion}

Sensor names are represented numerically by the instrumentation layer in which the sensor is located and by the assigned sensor number for that layer. Layer 1 is represented by a 1, Layer 2 is represented by a 2, and so forth. The complete name of the sensor is denoted by the layer number - the sensor number. For example, the second sensor on Layer 1 is named 1-02.

\subsubsection{Temperature}

Temperature is monitored with thermistors manufactured by Quality Thermistor, Inc. Thermistors with a temperature range of $0^{\circ} \mathrm{C}$ to $100^{\circ} \mathrm{C}$ were chosen so they would be able to accommodate the temperature ranges expected in both the anaerobic and aerobic cells. Currently, resistance was measured manually by connecting the sensor wires to a 26 III Multimeter manufactured by Fluke Corporation.

Temperature results are presented in Appendix C, Figures 4-1 to 4-3. A summary of the results is presented below in Table 4-4 and Figure 4-4.

Table 4-4. Temperature Summary for the West-Side Anaerobic Cell

\begin{tabular}{|c|c|c|c|c|c|c|}
\hline & \multicolumn{3}{|c|}{$\begin{array}{c}\text { Previous Reporting Period } \\
(10 / 1 / 02\end{array}$} & \multicolumn{3}{c|}{$\begin{array}{c}\text { Current Reporting } / \mathbf{0 2}) \\
(\mathbf{1 / 1 / 0 3} \text { to 3/31/03) }\end{array}$} \\
\hline Layer & $\begin{array}{c}\text { Minimum } \\
\text { Temp. }\left({ }^{\circ} \mathbf{C}\right)\end{array}$ & $\begin{array}{c}\text { Maximum } \\
\text { Temp. }\left({ }^{\circ} \mathbf{C}\right)\end{array}$ & $\begin{array}{c}\text { Average } \\
\text { Temp. }\left({ }^{\circ} \mathbf{C}\right)\end{array}$ & $\begin{array}{c}\text { Minimum } \\
\text { Temp. }\left({ }^{\circ} \mathbf{C}\right)\end{array}$ & $\begin{array}{c}\text { Maximum } \\
\text { Temp. }\left({ }^{\circ} \mathbf{C}\right)\end{array}$ & $\begin{array}{c}\text { Average } \\
\text { Temp. }\left({ }^{\circ} \mathbf{C}\right)\end{array}$ \\
\hline 1 & 34.3 & 43.8 & 40.5 & 37.7 & 42.8 & 40.7 \\
\hline 2 & 43.7 & 45.6 & 44.4 & 27.8 & 49.9 & 43.5 \\
\hline 3 & 43.9 & 58.8 & 48.1 & 42.8 & 54.8 & 47.4 \\
\hline
\end{tabular}


Figure 4-4. Average Temperatures for the West-Side Anaerobic Cell

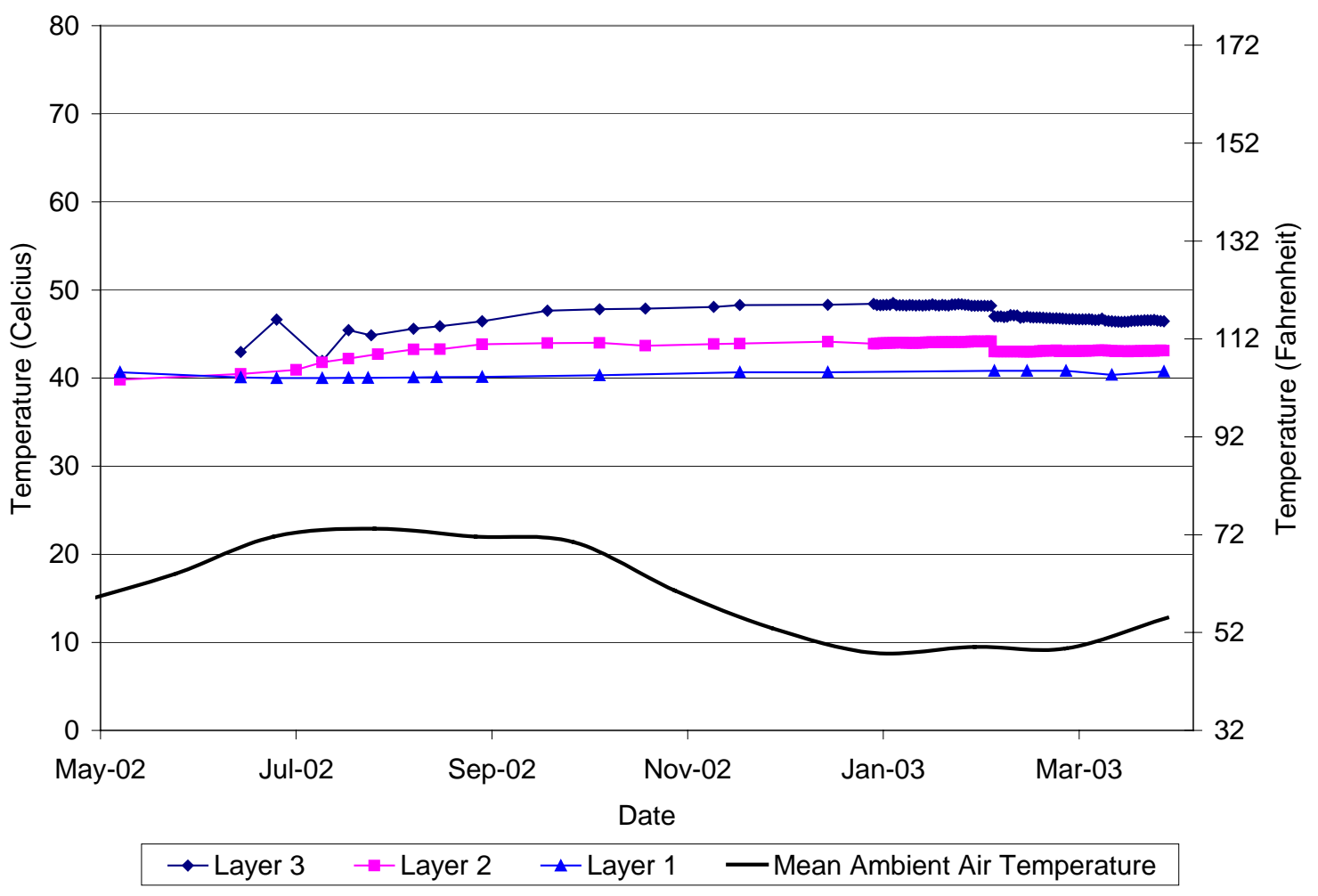

\subsubsection{Moisture}

Moisture is measured manually with a Model MM 4 moisture meter manufactured by Electronics Unlimited. Moisture data are unitless numbers that give a qualitative assessment rather than a quantitative measure. During the pilot scale project, Yolo County conducted laboratory tests with the PVC sensors to determine the relationship between the multimeter readings and the presence of free liquid in the PVC sensor. It was determined that a meter reading of less than 40 corresponded to an absence of free liquid. A reading between 40 and 80 corresponds to the presence of free liquid in the PVC pipe but less than saturated conditions. Readings of greater than 80 indicate saturated conditions; i.e. the PVC sensor is full of liquid.

Moisture results are presented in Appendix C, Figures 4-5 to 4-7. A summary of the results is presented below in Table 4-5 and Figure 4-8. 
Table 4-5. PVC Moisture Summary for the West-Side Anaerobic Cell

\begin{tabular}{|c|c|c|c|c|c|c|}
\hline & \multicolumn{3}{|c|}{$\begin{array}{c}\text { Previous Reporting Period } \\
(\mathbf{1 0 / 1 / 0 2} \text { to12/31/02) }\end{array}$} & \multicolumn{3}{c|}{$\begin{array}{c}\text { Current Reporting Period } \\
(\mathbf{1 / 1 / 0 3} \text { to 3/31/03) }\end{array}$} \\
\hline Layer & $\begin{array}{c}\text { Minimum } \\
\text { Moisture }\end{array}$ & $\begin{array}{c}\text { Maximum } \\
\text { Moisture }\end{array}$ & $\begin{array}{c}\text { Average } \\
\text { Moisture }\end{array}$ & $\begin{array}{c}\text { Minimum } \\
\text { Moisture }\end{array}$ & $\begin{array}{c}\text { Maximum } \\
\text { Moisture }\end{array}$ & $\begin{array}{c}\text { Average } \\
\text { Moisture }\end{array}$ \\
\hline 1 & 27.0 & 67.4 & 40.1 & 38.4 & 82.2 & 59.6 \\
\hline 2 & 0.8 & 66.6 & 66.2 & 2.7 & 94.8 & 75.5 \\
\hline 3 & 39.4 & 47.8 & 42.6 & 4.5 & 88.2 & 51.3 \\
\hline
\end{tabular}

Figure 4-8. Average Moisture Levels for the West-Side Anaerobic Cell

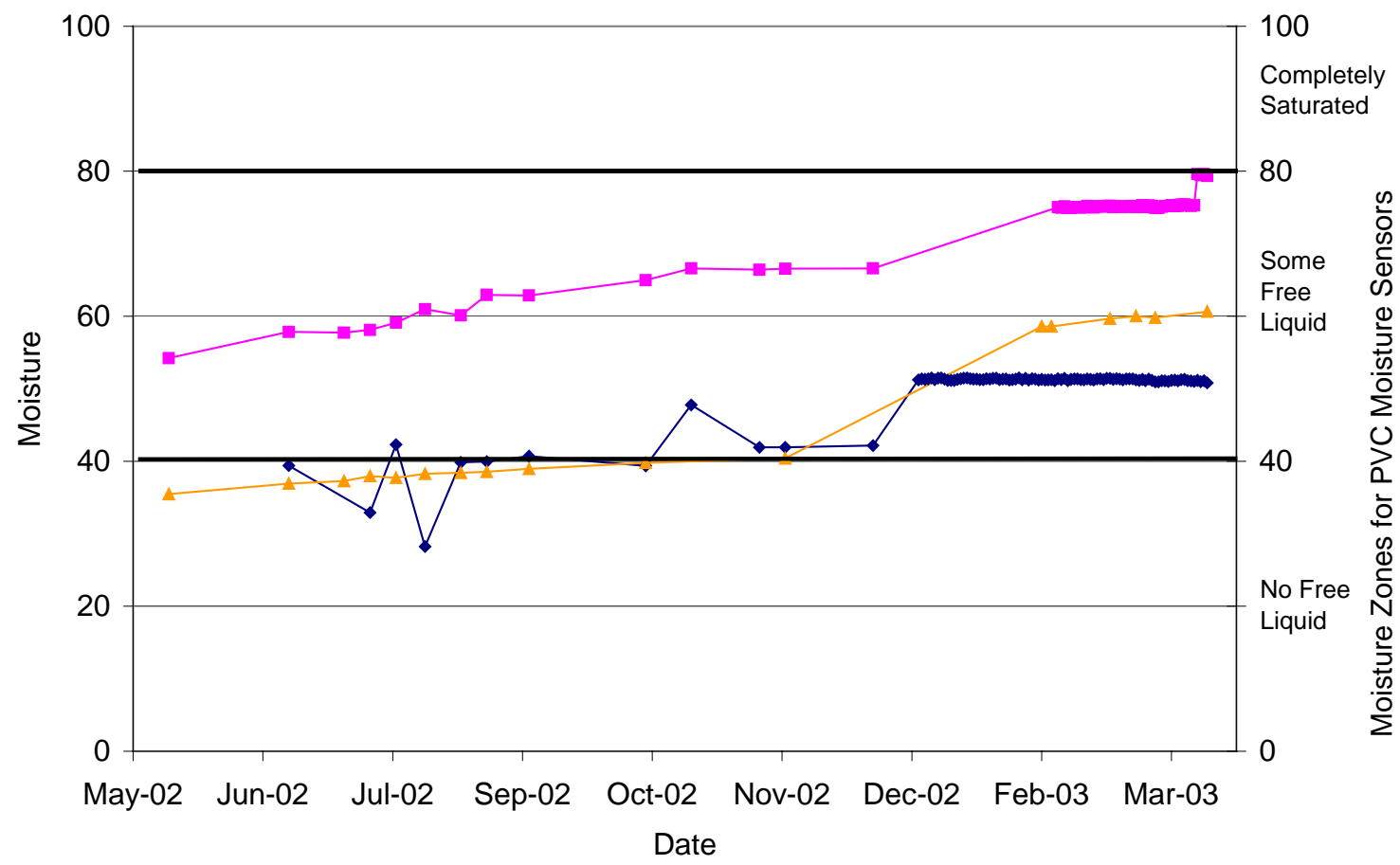

Date

$\rightarrow$ Layer $3 \quad \rightarrow$ Layer $2 \quad \rightarrow$ Layer 1

\subsubsection{Landfill Gas Collection System}

Gas composition is measured from the base layer and the wellheads located on top of the westside anaerobic cell with the GEM-500. Gas flow is measured by differential pressures utilizing a 1/8-inch diameter pitot tube by DWYER Instruments, Inc., in combination with the GEM-500. A thermal mass flow meter will be installed in the main header pipeline to record flow rate and total flow for west-side anaerobic cell.

Landfill gas results are presented in Appendix C, Figures 4-9 to 4-11. Methane concentrations from the wellhead fluctuate based on the applied vacuum, barometric pressure, and the status of waste decomposition. After surface liner installation in October 2002, the collection rate of landfill gas drastically increased. Additionally, methane and carbon dioxide concentrations 
increased while and oxygen and balance concentrations decreased. A summary of the results is presented below in Table 4-6.

Table 4-6. Landfill Gas Summary for the West-Side Anaerobic Cell.

\begin{tabular}{|l|l|l|l|}
\hline Parameter & \multicolumn{3}{|l|}{ Results } \\
\hline $\begin{array}{l}\text { Cumulative Methane from } \\
\text { May 7, 2002 to March 31, 2003 }\end{array}$ & $\begin{array}{l}5.3 \times 10^{6} \text { standard cubic feet (scf) } \\
\text { (which is equivalent to approximately 850 } \\
\text { barrels of oil) }\end{array}$ \\
\hline $\begin{array}{l}\text { LFG Flow Rate for the period of } \\
\text { January 1, 2003 to March 31, 2003 }\end{array}$ & Minimum & Maximum & Average \\
\cline { 2 - 4 } $\begin{array}{l}\text { Methane Concentration for the period of } \\
\text { January 1, 2003 to March 31, 2003 }\end{array}$ & Minimum & Maximum & Average \\
\cline { 2 - 4 } & $33.4 \%$ & $46.7 \%$ & $40.1 \%$ \\
\hline
\end{tabular}

Landfill gas was sampled from the west-side base layer wellhead in March 2003 and sent to an independent laboratory for analytical testing. Analytical results are presented in Appendix D.

Landfill gas will be sampled on a quarterly basis when liquid addition commences in the westside anaerobic cell.

\subsubsection{Leachate Quantity And Quality}

Prior to October 2001, leachate data reflects rainfall rather than actual leachate generation because the cells were only partially filled, and portions of the leachate collection and removal system were exposed to rainfall. Between October 2001 and March 2003, approximately

116,000 gallons of leachate was generated from the west-side cell (Appendix C, Figure 4-12).

Leachate was last sampled in February 2003 for analytical testing. Analytical results are presented in Appendix E, Table 4-7. Field chemistry and selected analytical results are presented below in Table 4-8. Analytical results show only a decline in COD, conductivity, metals, and volatile organic compounds since February 2002. Leachate will be sampled on a monthly basis once liquid addition commences. 
Table 4-8. Field Chemistry and Selected Laboratory Chemistry for Leachate Sampled from the West-Side Anaerobic Cell

\begin{tabular}{|l|c|c|c|c|c|c|c|}
\hline PARAMETER & DATE: & $\mathbf{2 / 1 4 / 2 0 0 2}$ & $\mathbf{5 / 1 4 / 2 0 0 2}$ & $\mathbf{6 / 2 0 / 2 0 0 2}$ & $\mathbf{7 / 2 3 / 2 0 0 2}$ & $\mathbf{8 / 1 3 / 2 0 0 2}$ & $\mathbf{2 / 2 6 / 2 0 0 3}$ \\
\hline Field Parameters: & Units & & & & & & \\
\hline pH & & 6.74 & 6.8 & 6.72 & 6.85 & 6.71 & 6.87 \\
\hline Electrical Conductivity & $\mu \mathrm{S}$ & 3530 & 3851 & 3944 & 3899 & 3810 & 2320 \\
\hline Oxidation Reduction Potential & $\mathrm{mV}$ & -62 & -46 & -19 & -38 & -36 & -56 \\
\hline Temperature & $\mathrm{C}$ & 24.9 & 26.2 & 25.2 & 25.7 & 26.9 & 22.1 \\
\hline Dissolved Oxygen & $\mathrm{mg} / \mathrm{L}$ & 3.15 & 1.54 & 1.31 & 3.62 & 2.6 & 3.18 \\
\hline Total Dissolved Solids & $\mathrm{ppm}$ & 2617 & 2871 & 2960 & 2965 & 2908 & 1703 \\
\hline General Chemistry: & & & & & & & \\
\hline Bicarbonate Alkalinity & $\mathrm{mg} / \mathrm{L}$ & 1700 & 1780 & 1730 & 1710 & 1680 & 1000 \\
\hline Total Alkalinity as CO 3 & $\mathrm{mg} / \mathrm{L}$ & 1700 & 1780 & 1730 & 1710 & 1680 & 1000 \\
\hline BOD & $\mathrm{mg} \mathrm{O} / \mathrm{L}$ & 28 & 12 & 12 & 7.9 & 12 & 16 \\
\hline Chemical Oxygen Demand & $\mathrm{mg} \mathrm{O} / \mathrm{L}$ & 350 & 300 & 274 & 270 & 262 & 98.1 \\
\hline Chloride & $\mathrm{mg} / \mathrm{L}$ & 187 & 333 & 358 & 341 & 366 & 196 \\
\hline Ammonia as N & $\mathrm{mg} / \mathrm{L}$ & 20.3 & 23.5 & 21.2 & 23.8 & 25 & 9.5 \\
\hline Nitrate-Nitrite as N & $\mathrm{mg} / \mathrm{L}$ & $0.016(\mathrm{tr})$ & $<1.5$ & $<0.03$ & $<0.015$ & $<0.015$ & 0.022 (tr) \\
\hline Total Kjeldahl Nitrogen & $\mathrm{mg} / \mathrm{L}$ & 32.6 & 31.1 & 31.5 & 31.4 & 31 & 13.8 \\
\hline Total Dissolved Solids @ 180 C & $\mathrm{mg} / \mathrm{L}$ & 2220 & 2320 & 2410 & 2310 & 2280 & 1320 \\
\hline Total (Non-Volatile) Organic Carbon & $\mathrm{mg} / \mathrm{L}$ & 112 & 85.2 & 86.5 & 82.7 & 78.1 & 28.3 \\
\hline Total Sulfide & $\mathrm{mg} / \mathrm{L}$ & $0.033(\mathrm{tr})$ & $<0.014$ & $<0.014$ & $0.023(\mathrm{tr})$ & $<0.014$ & $<0.0093$ \\
\hline Dissolved Iron & $\mathrm{mg} / \mathrm{L}$ & 0.4 & $0.035(\mathrm{tr}) *$ & 1.9 & 0.59 & 0.11 & 0.15 \\
\hline Dissolved Magnesium & $\mathrm{mg} / \mathrm{L}$ & 198 & 343 & $\mathrm{NA}$ & 217 & 185 & 123 \\
\hline Dissolved Potassium & $\mathrm{mg} / \mathrm{L}$ & 55.2 & 58.6 & $\mathrm{NA}$ & 37.8 & 32.5 & 23.7 \\
\hline
\end{tabular}

\section{AEROBIC CELL}

The aerobic cell occupies approximately 2.5 acres in the southeast quadrant of Phase 1, Module 6D.

\subsection{Experimental}

The experimental methods utilized are grouped into three categories: construction, monitoring, and operation. Each of these categories is discussed below.

\subsubsection{Construction}

Construction of the aerobic cell can be generally broken down into five major tasks: waste placement, liquid addition, gas collection, air injection and surface liner installation. Each of the five tasks is discussed below. Refer to Appendix A, Table 5-1 for a summary of current monitoring data for the aerobic cell. 


\subsubsection{Waste Placement}

Waste placement first began November 14, 2000 with an approximate 10-foot lift of waste placed on the Module 6D liner. This first lift of waste will act as a buffer between the Module 6D primary liner and the future aerobic cell. The waste was graded to promote drainage and a 60-mil HDPE geomembrane (Image 5-1) was installed to capture all leachate being generated by the aerobic cell. A sixteen-ounce geotextile was then placed on the membrane to act as a cushion for a shredded tire operations layer.

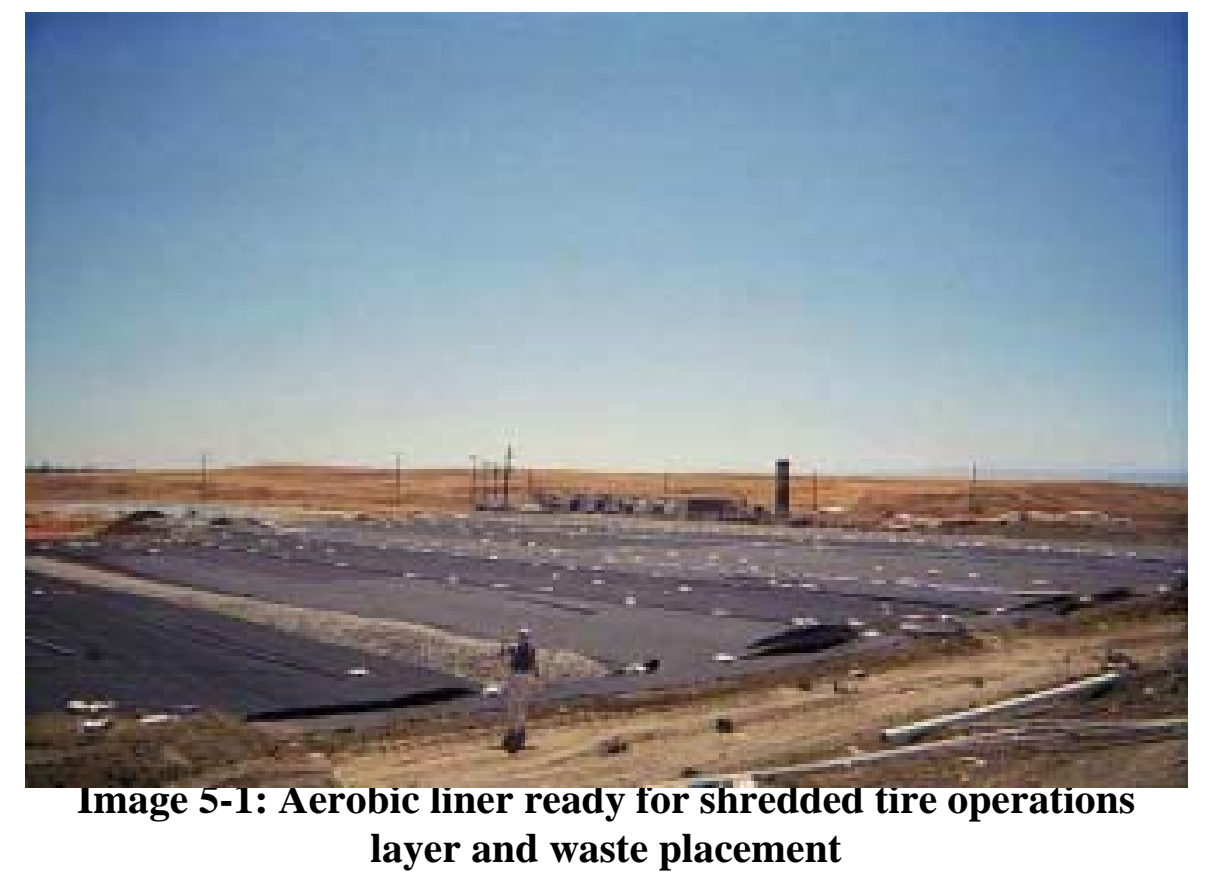

Waste placement in the aerobic cell occurred between August 8, 2001 and September 26, 2001. Waste was placed in three 10-foot lifts with 2:1 side slopes on the north, east and west (internal side slopes), and a 3:1 side slope on the south (external side slope) as presented in Detail 5-1. Because of the limited tipping area of the aerobic cell, self-haul waste was excluded. The use of daily cover soil during waste filling was also minimized to aid in the overall permeability of the waste. Whenever possible, greenwaste or tarps were used as alternative daily cover (ADC) and, in the event soil was placed (for example, access roads or tipping pad), the soil was removed prior to placing the next lift of waste. To further aid permeability of the waste, compaction was restricted to only 1 to 2 passes with a Caterpillar 826 compactor. Based on waste tonnage records and as-built topography, the in-place refuse density is approximately 800 pounds per cubic yard. Instrumentation Layers 1 and 2 were placed between lifts, and base layer instrumentation was installed on the aerobic cell base liner. A summary of sensors installed on each layer is provided in Appendix A, Table 5-2. 


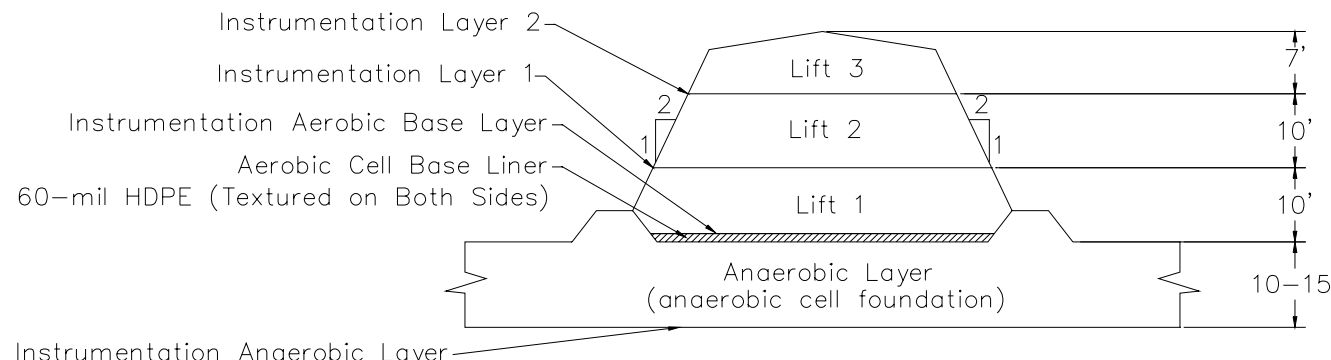

\section{Detail 5-1. Aerobic Cell Cross Section Cell}

\subsubsection{Liquid Addition}

Horizontal liquid injection lines were installed in each lift of waste. Injection lines within the waste (between lifts 1 and 2, 2 and 3) were placed horizontally (north to south) every 20 feet. Injection lines on top of lift 3 were placed east to west every 20 feet. Various combinations of 11/4-inch-diameter chlorinated polyvinyl chloride (CPVC) and 11/4-inch-diameter HDPE pipe were installed and perforated with ${ }^{3} /{ }_{32}$-inch-diameter holes spaced every 10 feet (Image 5-2). Because of the elevated temperatures expected in the aerobic cell, CPVC was installed a selected locations as a redundancy in the event the HDPE piping fails (CPVC is rated for service at temperatures up to $200^{\circ} \mathrm{F}$, however is approximately 4 times as expensive). A total of 4,780 feet of injection piping was installed with a total of 326 injection holes.

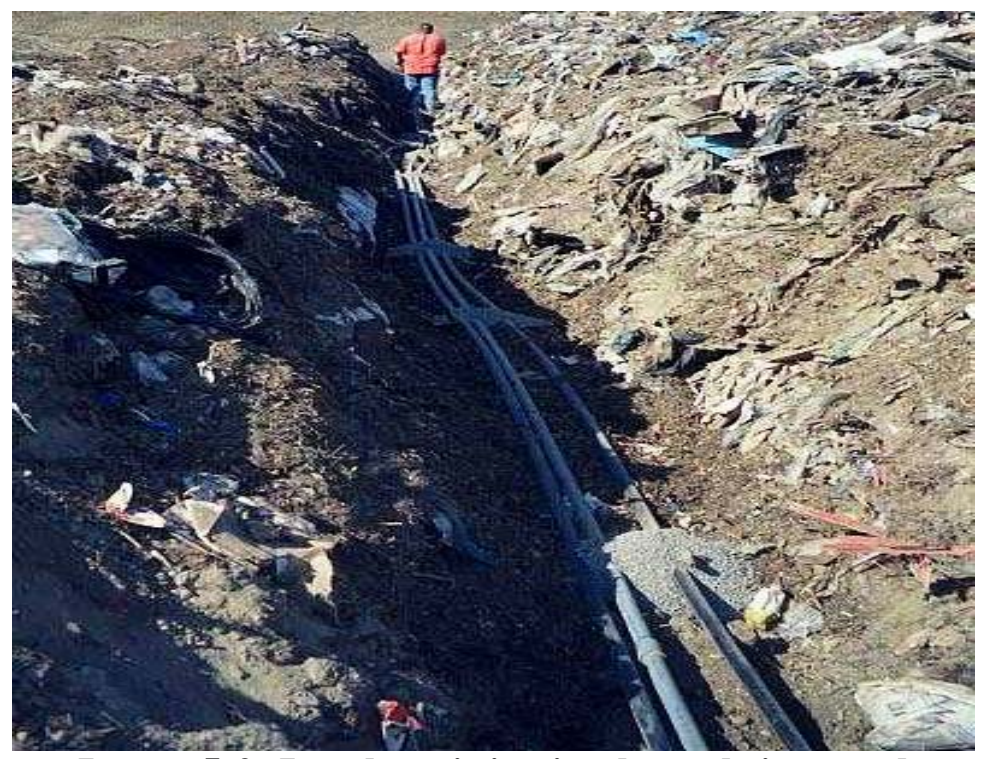

Image 5-2: Leachate injection laterals in trench 
Each of the injection laterals will be connected to a 4-inch-diameter HDPE injection header. Flow rate and pressure will be monitored at each injection lateral. Leachate injection for each lateral will be monitored and controlled by individual solenoid valves connected to the SCADA system. A second redundant flow meter will monitor the total volume and flow rate being injected in the aerobic cell.

\subsubsection{Air Collection}

Horizontal air collection lines were installed between each lift of waste. Air collection lines consist of various combinations of alternating 4 and 6-inch-diameter CPVC pipe and 6 and 8inch-diameter corrugated metal pipe (Image 5-3). Each air collection line utilizes shredded tires as the permeable media. The air collection lines between layers are spaced approximately 40 feet apart. A total of 1660 feet of horizontal air collection lines were installed. A summary of the air collection lines for the aerobic cell is shown in Appendix A, Table 5-3.

Each air collection line will be connected to a 12-inch-diameter air collection header that will convey the gas to and on-site blower and biofilter. Each air collection line will incorporate a premanufactured wellhead capable of controlling flow and monitoring flow rate, temperature and pressure. Construction of the blower station commenced in December 2002 and installation of piping from the blower station to the biofilter commenced in February 2003.

\subsubsection{Surface Liner}

Vector was retained to provide design, plans and specifications for a surface lining system, including a biofilter for the treatment of the aerobic off-gas.

Since the operation of an aerobic bioreactor at the Yolo County Central Landfill was first considered, two methods of air management for oxygen delivery have been discussed. One method is to push air into the landfill and the other is to apply a vacuum and draw air through the landfill. Both methods have advantages and disadvantages. However, Yolo County has decided that the best alternative is to leave the aerobic cell covered with soil and greenwaste (shredded yard waste), but without an impermeable geomembrane, so that air could be drawn through the waste by applying a vacuum. In this way, air will enter through the cell surface and migrate to horizontal pipelines to which a vacuum is applied. Alternate operations plans could include using some of the installed pipelines as vents and others for vacuum.

Yolo County had intended to cover the aerobic cell with an exposed geomembrane with a biofilter at the top of the cell to provide some treatment of the off-gas. However, the weight of the geomembrane that would have been placed on the aerobic cell along with the weight of a sandbag surface ballast system would result in a pressure equivalent to only 0.17 inches of water. Calculations indicate that the required pressure present in the cell to force the air through the waste, to the top of the cell, and through the biofilter would result in a great deal of ballooning of the surface liner. Additionally, the expected high settlement rate would create a great deal of maintenance difficulties for the geomembrane surface liner.

Yolo County developed a design for a geomembrane surface liner for the aerobic cell and advertised for bids on the construction. The bids received were very expensive and not within the budget of the project. As a result of both the technical and economic difficulties encountered, it was decided that leaving the aerobic cell without a geomembrane liner is the preferred approach. 


\subsubsection{Monitoring}

Temperature, moisture, leachate quantity and quality, and air pressure and composition are monitored through an array of sensors placed within the waste (Image 5-4) and in the leachate collection and recovery system (LCRS).

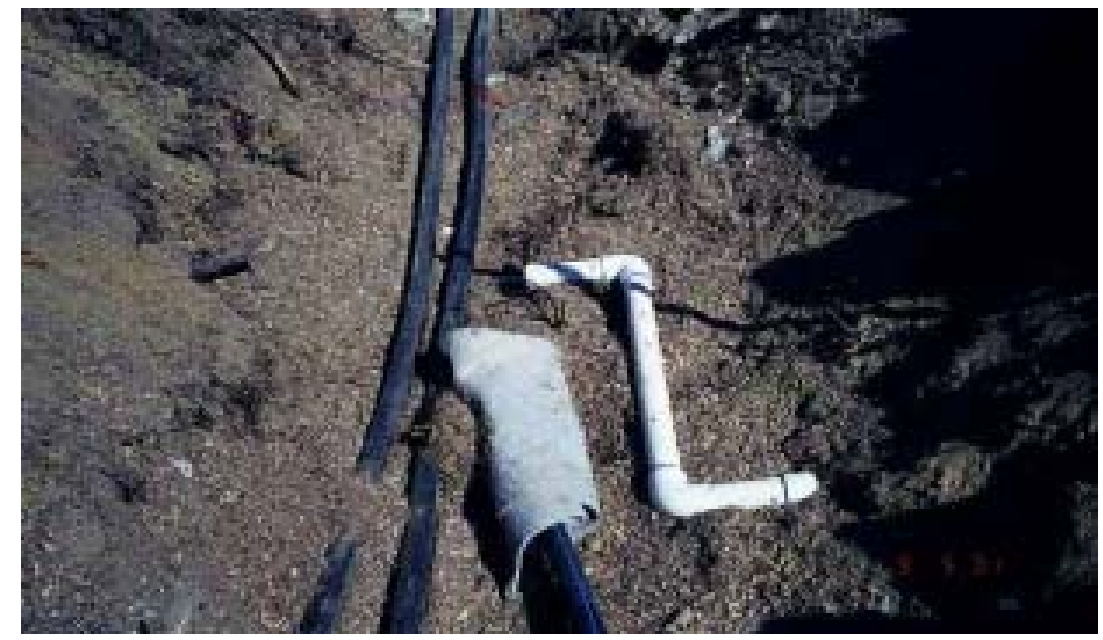

Image 5-4: Moisture, temperature, and tube installation

Each sensor location received a temperature sensor (thermistor), a moisture sensor (a PVC moisture sensor and in some cases a gypsum block) and a linear low-density polyethylene (LLDPE) tube. For protection, each wire and tube was encased in a 1.25-inch-diameter HDPE pipe. Refer to Appendix B, Details 5-2 through 5-5 for sensor location diagrams.

Sensors on instrumentation Layers $0.5,1$, and 2 were placed on a bedding of greenwaste (shredded yard waste), or bin fines (fine pieces of greenwaste). Sensors installed on the primary liner (prior to any waste placement) were placed on the geotextile and covered with pea gravel prior to the placement of the shredded tire operations layer.

\subsubsection{Temperature}

Temperature is monitored with thermistors manufactured by Quality Thermistor, Inc. Thermistors with a temperature range of $0^{\circ} \mathrm{C}$ to $100^{\circ} \mathrm{C}$ were chosen to accommodate the temperature ranges expected in both the anaerobic and aerobic cells. To prevent corrosion, each thermistor was encased in epoxy and set in a stainless steel sleeve. All field wiring connections were made by first soldering the connection, then covering each solder joint with adhesive-lined heat shrink tubing, and then encasing the joint in electrical epoxy. Changes in temperature are measured by the change in thermistor resistivity (ohms). As temperature increases, thermistor resistance decreases.

\subsubsection{Moisture}

Moisture levels are measured with polyvinyl chloride (PVC) moisture sensors and gypsum blocks. Both the PVC moisture sensors and gypsum blocks are read utilizing the same meter. The PVC sensors are perforated 2-inch-diameter PVC pipes with two stainless steel screws spaced 8 inches apart and attached to wires to form a circuit that includes the gravel filled pipe. The PVC sensors were designed by Yolo County and used successfully during the pilot scale 
project. The PVC moisture sensor can provide a general, qualitative assessment of the waste's moisture content. A reading of 0 to 40 equates to no free liquid, 40 to 80 equates to some free liquid, and 80 to 100 means completely saturated conditions.

The gypsum blocks are manufactured by Electronics Unlimited and are typically used for soil moisture determinations in agricultural applications. Gypsum blocks establish equilibrium with the media in which they are placed and are, therefore, reliable at tracking increases in the soil's moisture content. However, the gypsum block can take considerable time to dry and therefore may not reflect the drying of the surrounding environment.

\subsubsection{Leachate Quantity and Quality}

Leachate that is generated from the aerobic cell will drain to a separate leachate sump installed on top of the eastside Module D leachate collection sump (Image 5-5). A dedicated pump is then used to remove the leachate and pump it to one of the on-site leachate storage ponds. A flow meter will measure rate and total volume pumped from the sump.

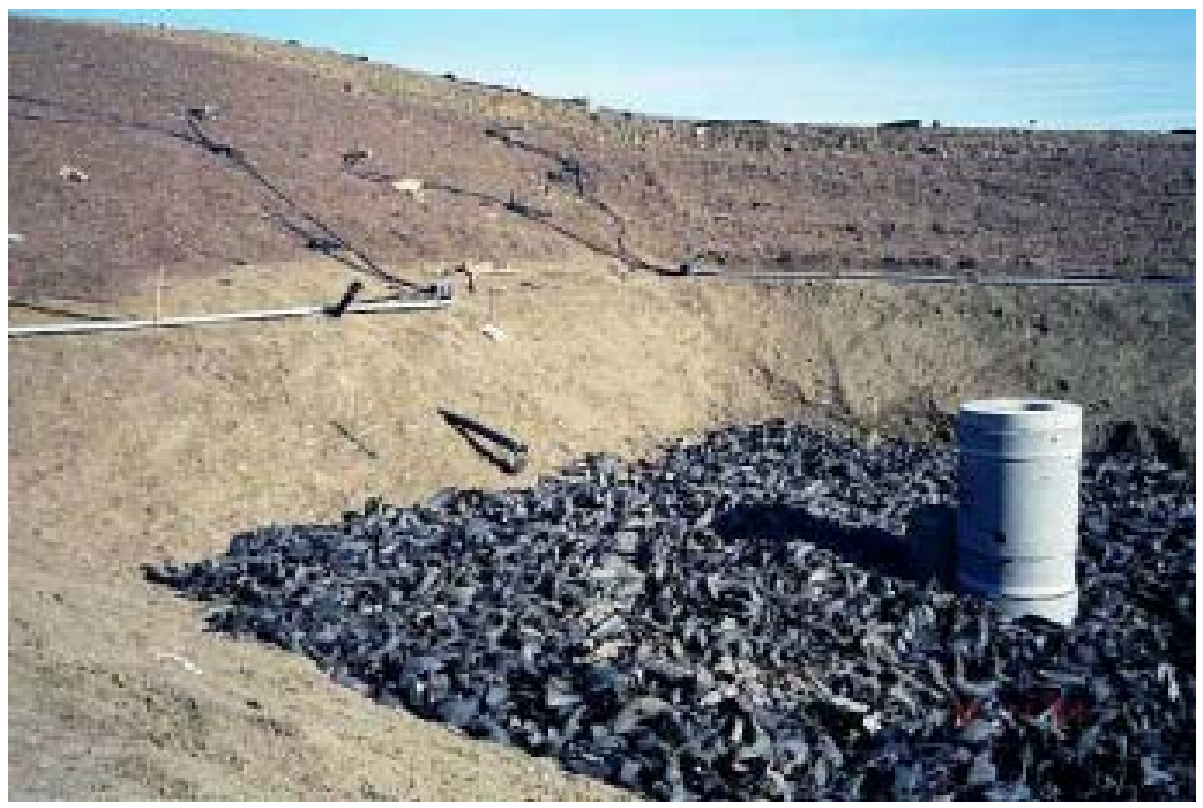

Image 5-5: Aerobic sump installed and ready for backfill

Leachate is monitored for the following field parameters: $\mathrm{pH}$, electrical conductivity, dissolved oxygen, oxidation-reduction potential, and temperature. When leachate is generated in sufficient quantities, the following parameters will be analyzed by a laboratory: dissolved solids, biochemical oxygen demand, chemical oxygen demand, organic carbon, nutrients $\left(\mathrm{NH}_{3}, \mathrm{TKN}\right.$, $\mathrm{TP}$ ), common ions, heavy metals and organic priority pollutants. For the first year, monitoring will be conducted monthly for the first six months and quarterly for the following six months. After the first year, monitoring will be conducted semi-annually $(\mathrm{pH}$, conductivity, and flow rate will continue to be monitored on a monthly basis as required by the State of California's amended Waste Discharge Requirements in Order 5-00-134). 


\subsubsection{Pressure}

Pressure within the aerobic cell is monitored with $1 / 4$-inch inner diameter and $3 / 8$-inch outer diameter LLDPE sampling tubes. Each tube can be attached to a pressure gage and supplemental air source. By first purging the tube with the air source (to remove any liquid blockages), and then reading the pressure, an accurate gas and/or water pressure can be measured at each sensor location.

\subsubsection{Landfill Gas Composition and Flow}

Landfill gas composition and flow are measured from the pre-manufactured well heads utilizing a GEM-500 combustible gas meter, manufactured by LANDTEC. The GEM-500 is capable of measuring methane (either as a percent by volume or percent of the lower explosive limit), carbon dioxide, and oxygen. A reading for "balance" gas is also provided, which is assumed to be nitrogen.

\subsubsection{Waste Sampling}

Yolo County conducted the first waste sampling event for the aerobic cell on June 5, 2002. Waste was sampled to quantify the methane generation potential of the waste. Waste was drilled to an approximate depth of 30 feet with samples taken at 5-foot intervals. Waste will be sampled from the aerobic cell annually for the next two years to monitor the progress of waste decomposition and compare actual methane generation to laboratory methane generation.

\subsubsection{Surface Scan}

Under current federal guidelines (40 CFR 60.752), landfills exceeding a specific size must monitor for methane surface emissions and any reading in excess of 500 PPM (40 CFR 60.755 (c)) requires corrective action to be taken. The Yolo County Central Landfill is not currently required to test for methane surface emissions, however, as part of the FPA, the County has proposed to conduct quarterly surface scans to demonstrate the emissions (or lack of) from a controlled bioreactor landfill.

Methane concentrations are monitored with a model TVA-1000 Flame Ionization Detector (FID)/ Photo Ionization Detector (PID) instrument. Under the FID setting, the TVA-1000 is capable of detecting methane in the parts-per-million (PPM) range and has an accuracy of \pm 2.5 PPM or 25 percent of the reading, whichever is greater. In the event significant methane was detected, the unit could be switched to PID mode to detect volatile organic compounds (VOC). Methane surface concentrations are monitored along the perimeter of the collection area and along a pattern that transverses the landfill at 15 meter intervals. Due to high winds and inclement weather, the surface scan scheduled for December 2002 was postponed until January 2003. The March 2003 aerobic cell surface scan was postponed until April 2003 due to an insufficient supply of hydrogen (needed for the FID) shipped with the instrument. . A summary of the surface scans performed on the aerobic cell is presented below in Table 5-4. 
Table 5-4. Summary of Surface Scans Performed on the Aerobic Cell

\begin{tabular}{|c|l|c|l|}
\hline $\begin{array}{c}\text { Surface } \\
\text { Scan No. }\end{array}$ & \multicolumn{1}{|c|}{ Date } & $\begin{array}{c}\text { Max. Emissions } \\
\text { Detected }\end{array}$ & \multicolumn{1}{|c|}{ Location of Max. Emissions } \\
\hline 1 & April 3, 2002 & $\begin{array}{c}\text { No fugitive } \\
\text { emissions } \\
\text { detected }\end{array}$ & Not applicable \\
\hline 2 & June 6, 2002 & $8 \mathrm{ppm}$ & Along the western perimeter of the cell \\
\hline 3 & September 20, 2002 & $3 \mathrm{ppm}$ & $\begin{array}{l}\text { South face of the cell near the leachate } \\
\text { collection sump }\end{array}$ \\
\hline 4 & January 7, 2003 & $0.9 \mathrm{ppm}$ & $\begin{array}{l}\text { South face of the cell along a gas collection } \\
\text { lateral. }\end{array}$ \\
\hline
\end{tabular}

The extremely low surface emissions detected from the aerobic cell are not surprising given the low moisture content of the waste (very little water has been added) and full scale operation of the cell has not commenced. Once operation begins, future surface scans should be able to demonstrate the surface emission potential of an aerobic bioreactor landfill.

The detection of surface emissions may also be due to landfill operations in nearby areas. While background concentrations were monitored prior to conducting the surface scan, changes in wind currents could have transported methane from adjacent areas. During June 2002 and September 2002, grading and waste filling activities in the adjacent west-side 6-acre area could have promoted the detection of gas emissions in the aerobic cell. Additionally, activities from Module D Phase II construction (which involved exposing waste form an adjacent unit to facilitate base liner installation) could have promoted the detection of gas emissions during the September 2002 surface scan. The surface emissions detected on the south face in January 2003 was due to a loose flex hose along a gas collection lateral that was immediately tightened.

The true methane emissions detected are also a function of the accuracy of the surface scan equipment. The TVA-1000 FID instrument has an accuracy of \pm 25 percent of reading or $\pm 2.5 \mathrm{ppm}$, whichever is greater, from 1.0 to $10,000 \mathrm{ppm}$. Thus many of the surface emissions are outside (below) the accuracy range and thereby assumed to be negligible.

\subsubsection{Operation}

Operation of the aerobic cell as a bioreactor will begin once the air collection system, leachate recirculation systems, and SCADA control systems are complete. At this time, we anticipate bioreactor operation to begin by the end of June 2003.

\subsubsection{Leachate Recirculation}

Initially, large volumes of liquid will be added to bring the waste to field capacity (Image 5-6). Once field capacity has been reached, only enough liquid to maintain field capacity will be added. We anticipate that greater volumes of liquid (compared to the anaerobic cells) will be necessary to maintain field capacity due to the removal of liquid by the air collection system. 


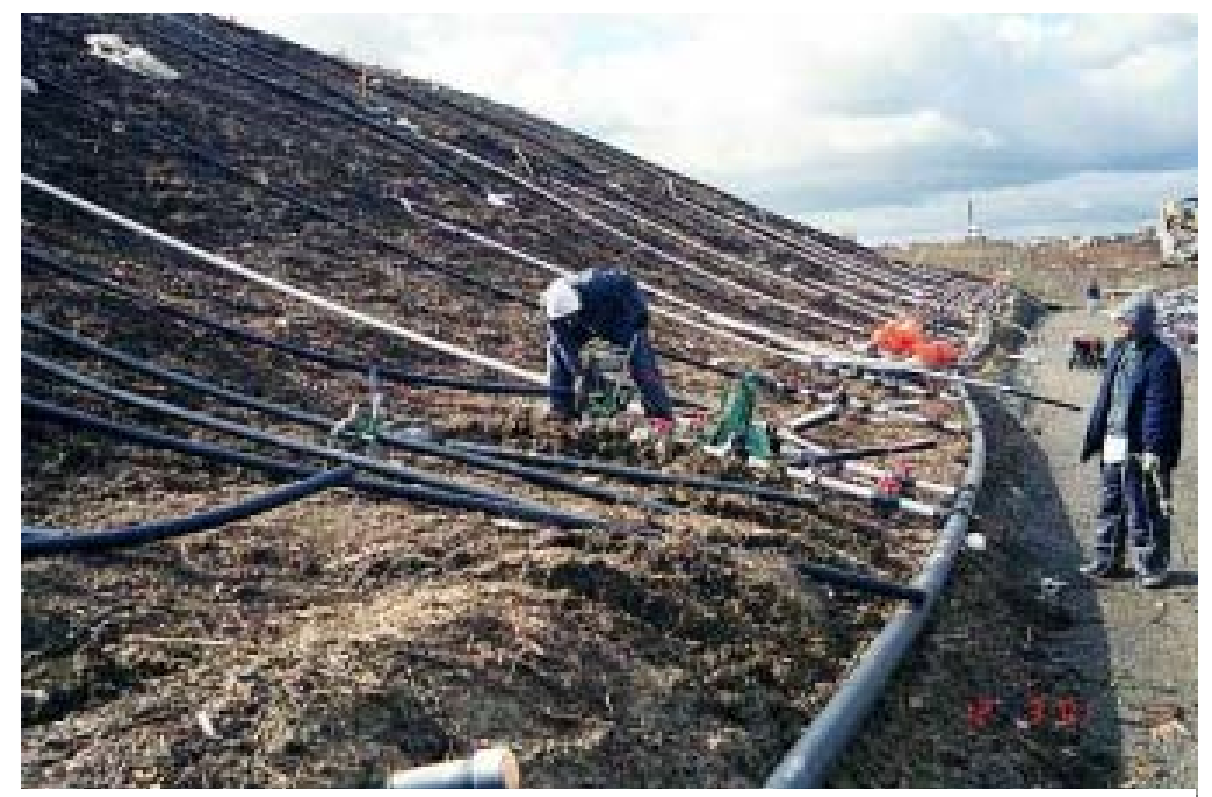

Image 5-6: Aerobic leachate injection header and lateral

\subsubsection{Air Collection}

Air collection will begin as soon as the necessary piping, blower, and biofilter is installed, which is anticipated to be in May 2003.

\subsection{Results And Discussion}

Sensor names are represented numerically by the instrumentation layer in which the sensor is located and by the assigned sensor number. The base layer is represented by a 0 , Layer 1 is represented by a 1 , and so forth. The complete name of the sensor is denoted by the layer number - the sensor number . For example, the second sensor on Layer 1 is named 1-02.

\subsubsection{Temperature}

Temperature is monitored with thermistors manufactured by Quality Thermistor, Inc. Thermistors with a temperature range of $0^{\circ} \mathrm{C}$ to $100^{\circ} \mathrm{C}$ were chosen so they would be able to accommodate the temperature ranges expected in both the anaerobic and aerobic cells. Resistance was measured by the SCADA system located in the instrumentation shed starting in March 2002. Resistance was previously measured manually by connecting the sensor wires to a 26 III Multimeter manufactured by Fluke Corporation.

Temperature results are presented in Appendix C, Figures 5-1 to 5-4. A summary of the results is presented below in Table 5-5 and Figure 5-5. 
Table 5-5. Temperature Summary for the Aerobic Cell

\begin{tabular}{|c|c|c|c|c|c|c|}
\hline & \multicolumn{3}{|c|}{$\begin{array}{c}\text { Previous Reporting Period } \\
(\mathbf{1 0 / 1 / 0 2} \text { to 12/31/02) }\end{array}$} & \multicolumn{3}{c|}{$\begin{array}{c}\text { Current Reporting Period } \\
(\mathbf{0 1 / 0 1 / 0 3} \text { to 03/31/03) }\end{array}$} \\
\hline Layer & $\begin{array}{c}\text { Minimum } \\
\text { Temp. }\left({ }^{\circ} \mathbf{C}\right)\end{array}$ & $\begin{array}{c}\text { Maximum } \\
\text { Temp. }\left({ }^{\circ} \mathbf{C}\right)\end{array}$ & $\begin{array}{c}\text { Average } \\
\text { Temp. }\left({ }^{\circ} \mathbf{C}\right)\end{array}$ & $\begin{array}{c}\text { Minimum } \\
\text { Temp. }\left({ }^{\circ} \mathbf{C}\right)\end{array}$ & $\begin{array}{c}\text { Maximum } \\
\text { Temp. }\left({ }^{\circ} \mathbf{C}\right)\end{array}$ & $\begin{array}{c}\text { Average } \\
\text { Temp. }\left({ }^{\circ} \mathbf{C}\right)\end{array}$ \\
\hline 0 & 30.6 & 61.9 & 44.3 & 25.4 & 61.2 & 41.6 \\
\hline 0.5 & 50.2 & 61.3 & 55.1 & 47.3 & 61.5 & 54.4 \\
\hline 1 & 35.7 & 73.2 & 54.4 & 17.4 & 72.1 & 51.0 \\
\hline 2 & 44.2 & 72.4 & 53.0 & 34.5 & 72.2 & 51.7 \\
\hline
\end{tabular}

Figure 5-5. Average Temperatures for the Aerobic Cell

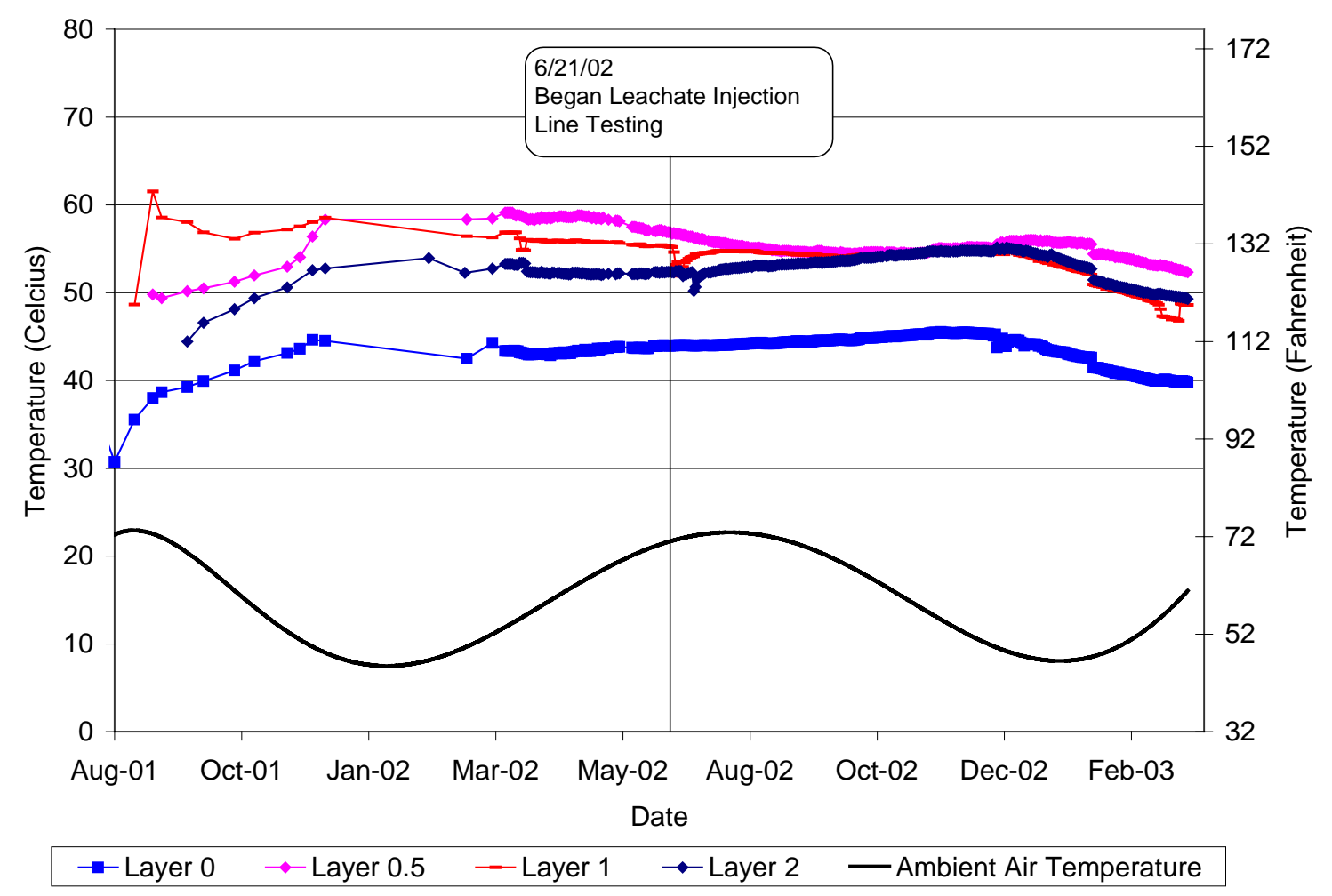

\subsubsection{Moisture}

The SCADA system started electronically measuring moisture in March 2002. Moisture was previously measured manually with a Model MM 4 moisture meter manufactured by Electronics Unlimited. During the pilot scale project, Yolo County conducted laboratory tests with the PVC sensors to determine the relationship between the multimeter readings and the presence of free liquid in the PVC sensor. It was determined that a meter reading of less than 40 corresponded to an absence of free liquid. A reading between 40 and 80 corresponds to the presence of free liquid in the PVC pipe but less than saturated conditions. Readings of greater than 80 indicate saturated conditions; i.e. the PVC sensor is full of liquid. 
PVC moisture results are presented in Appendix C, Figures 5-6 to 5-9. A summary of the results is presented below in Table 5-6 and Figure 5-10.

Table 5-6. PVC Moisture Summary for the Aerobic Cell

\begin{tabular}{|c|c|c|c|c|c|c|}
\hline & \multicolumn{3}{|c|}{$\begin{array}{c}\text { Previous Reporting Period } \\
(\mathbf{1 0 / 1 / 0 2} \text { to 12/31/02) }\end{array}$} & \multicolumn{3}{c|}{$\begin{array}{c}\text { Current Reporting Period } \\
\text { (01/01/03 to 03/31/03) }\end{array}$} \\
\hline Layer & $\begin{array}{c}\text { Minimum } \\
\text { Moisture }\end{array}$ & $\begin{array}{c}\text { Maximum } \\
\text { Moisture }\end{array}$ & $\begin{array}{c}\text { Average } \\
\text { Moisture }\end{array}$ & $\begin{array}{c}\text { Minimum } \\
\text { Moisture }\end{array}$ & $\begin{array}{c}\text { Maximum } \\
\text { Moisture }\end{array}$ & $\begin{array}{c}\text { Average } \\
\text { Moisture }\end{array}$ \\
\hline 0 & 3.0 & 94.8 & 31.5 & 3.2 & 46.9 & 94.8 \\
\hline 0.5 & 76.3 & 94.1 & 79.1 & 80.2 & 94.4 & 87.2 \\
\hline 1 & 10.6 & 90.2 & 46.8 & 10.3 & 89.9 & 56.1 \\
\hline 2 & 7.0 & 89.9 & 49.3 & 6.2 & 90.6 & 58.9 \\
\hline
\end{tabular}

Figure 5-10. Average Moisture Levels for the Aerobic Cell

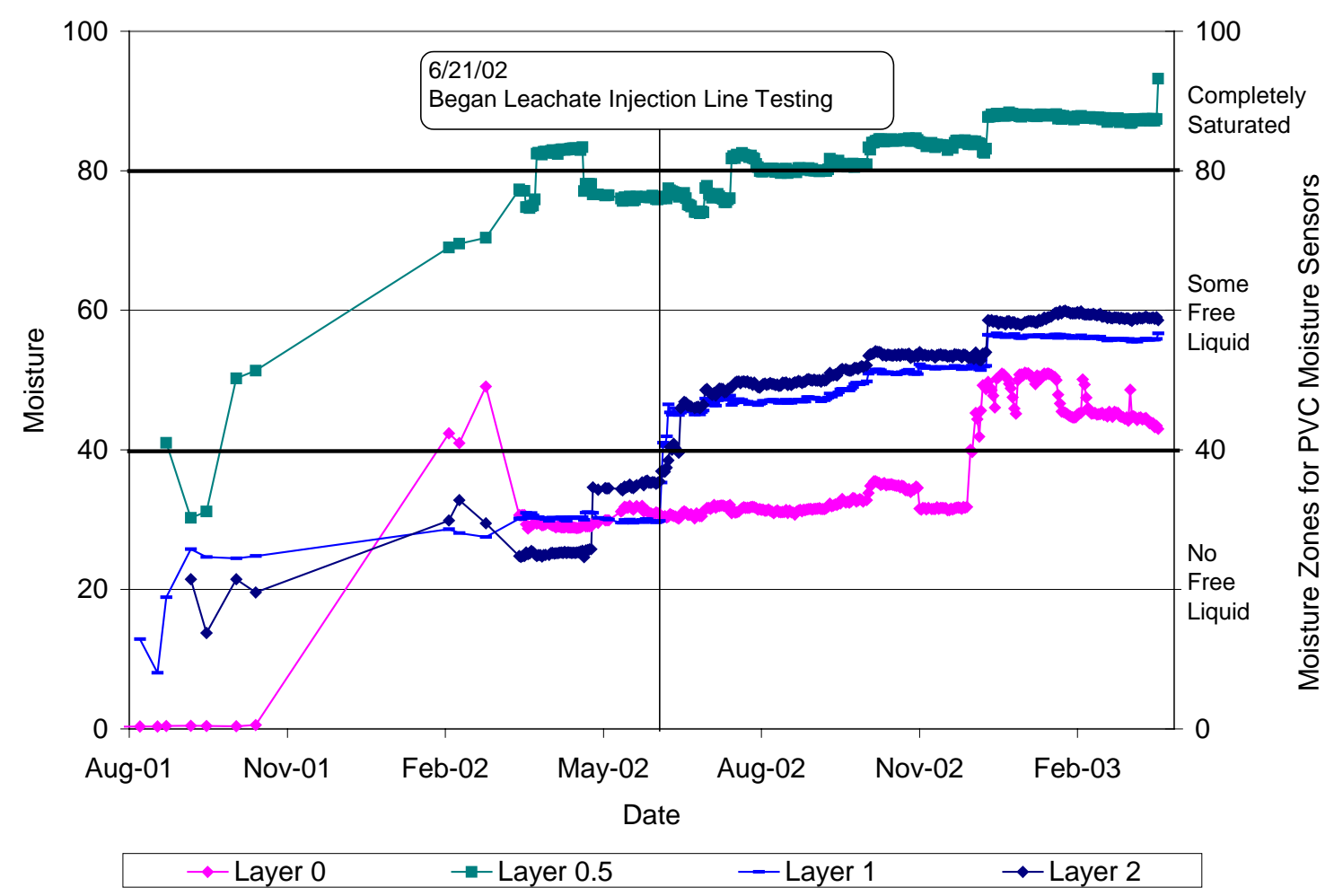

\subsubsection{Leachate Quantity And Quality}

Leachate was last sampled in May 2002 for analytical testing. Analytical results are presented in Appendix E, Table 5-7. Field chemistry and selected analytical results are presented below in Table 5-8. Leachate will be sampled on a monthly basis once liquid addition commences. 
Table 5-8. Field Chemistry for Leachate Sampled from the Aerobic Cell

\begin{tabular}{|l|c|c|c|c|}
\hline PARAMETER & DATE: & $\mathbf{2 / 2 6 / 2 0 0 2}$ & $\mathbf{3 / 2 7 / 2 0 0 2}$ & $\mathbf{5 / 1 4 / 2 0 0 2}$ \\
\hline Field Parameters: & Units & & & \\
\hline PH & & 7.75 & 8.17 & 8.48 \\
\hline Electrical Conductivity & $\mu \mathrm{moh} / \mathrm{cm}$ & 7026 & 7705 & 9048 \\
\hline Oxidation Reduction Potential & $\mathrm{MV}$ & 195 & 195 & 127 \\
\hline Temperature & $\mathrm{C}$ & 15.1 & 15.2 & 21.1 \\
\hline Dissolved Oxygen & $\mathrm{mg} / \mathrm{L}$ & 5.45 & 5.73 & 6.8 \\
\hline Total Dissolved Solids & $\mathrm{ppm}$ & 5673 & $\mathrm{NA}$ & 7448 \\
\hline General Chemistry: & & & & \\
\hline Ammonia as N & $\mathrm{mg} / \mathrm{L}$ & 2.8 & 1.1 & $0.60(\mathrm{tr})$ \\
\hline Bicarbonate & $\mathrm{mg} / \mathrm{L}$ & 1120 & 935 & 1020 \\
\hline BOD & $\mathrm{mg} \mathrm{O} / \mathrm{L}$ & 3.3 & 5 & 89 \\
\hline Chemical Oxygen Demand & $\mathrm{mg} \mathrm{O} / \mathrm{L}$ & 595 & 563 & 602 \\
\hline Chloride & $\mathrm{mg} / \mathrm{L}$ & 1610 & 1800 & 2290 \\
\hline Nitrate/Nitrite as N & $\mathrm{mg} / \mathrm{L}$ & 0.16 & 0.22 & $4.8(\mathrm{tr})$ \\
\hline Total (Non-Volatile) Organic Carbon & $\mathrm{mg} / \mathrm{L}$ & 766 & 149 & 168 \\
\hline Total Alkalinity as CaCO3 & $\mathrm{mg} / \mathrm{L}$ & 1120 & 935 & 1050 \\
\hline Total Dissolved Solids @ 180 C & $\mathrm{mg} / \mathrm{L}$ & 4810 & 5200 & 5640 \\
\hline Total Kjeldahl Nitrogen & $\mathrm{mg} / \mathrm{L}$ & 19.9 & 19.2 & 11.1 \\
\hline Total Sulfide & $\mathrm{mg} / \mathrm{L}$ & $<0.014$ & $0.015(\mathrm{tr})$ & $<0.014$ \\
\hline Dissolved Iron & $\mathrm{mg} / \mathrm{L}$ & 0.32 & $0.084(\mathrm{tr})$ & 0.34 \\
\hline Dissolved Magnesium & $\mathrm{mg} / \mathrm{L}$ & 273 & 260 & 220 \\
\hline Dissolved Potassium & $\mathrm{mg} / \mathrm{L}$ & $\mathrm{NA}$ & 66.1 & 47.8 \\
\hline
\end{tabular}

$\mathrm{NA}=$ Not Analyzed

Analytical results show an increase in several parameters such as BOD, sulfate, chloride, and several metals (i.e. barium, calcium, and manganese, etc.). However, there has also been a decline in ammonia, total organic carbon, and several metals including magnesium, sodium, and VOC's. Additional data is needed for a thorough assessment of the leachate parameters. When leachate is generated in more sufficient quantities, it will be sampled for analytical testing.

\section{MODULE 6D BASE LINER}

The three bioreactor cells share a common composite liner system, designated the Module 6D primary liner. This composite liner system was constructed in 1999 and was designed to exceed the requirements of Title 27 of CCR and Subtitle D of the Federal guidelines.

\subsection{Experimental}

The experimental methods utilized are grouped into two categories: construction and monitoring. Each of these categories is discussed below.

\subsubsection{Construction}

Construction of the Module 6D primary liner system can generally be separated into two tasks: grading and base liner assembly. 


\subsubsection{Grading}

The base layer of Module D was constructed in a ridge and swale configuration, enabling the west-side 6 -acre anaerobic cell to be hydraulically separated from the northeast anaerobic cell and the aerobic cell in the southeast quadrant. The base layer slopes 2 percent inward to two central collection v-notch trenches located on the southeast and southwest side of Module D (Detail 6-1). Each of the trenches drain at 1 percent to their respective leachate collection sumps located at the south side of the module.

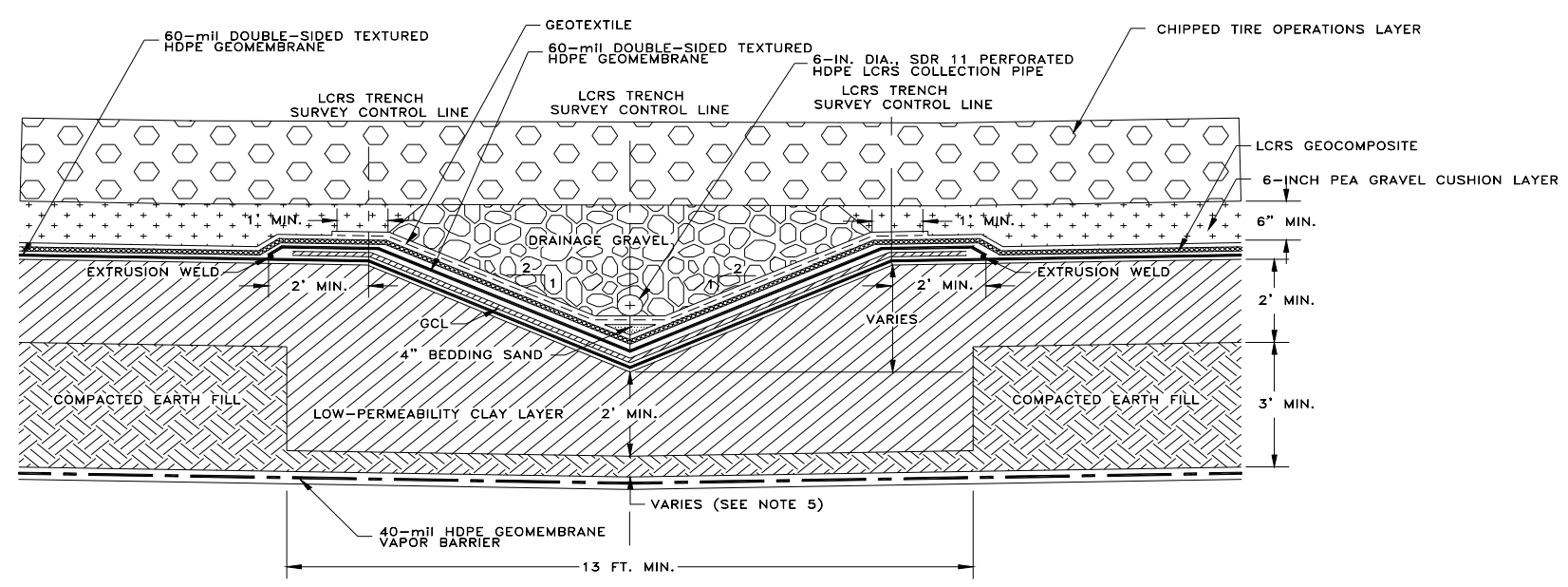

Detail 6-1. Module D Bottom Liner and Leachate Collection Trench Cross-Section

\subsubsection{Base Liner Assembly}

The liner is composed, from top to bottom, of the following materials: an operations/drainage layer consisting of 2 feet of chipped tires (permeability $[\mathrm{k}]>1$ centimeter per second $[\mathrm{cm} / \mathrm{s}]$ ) (Image 6-1), 6-inches of pea gravel, geocomposite drain net, a 60-mil high density polyethylene

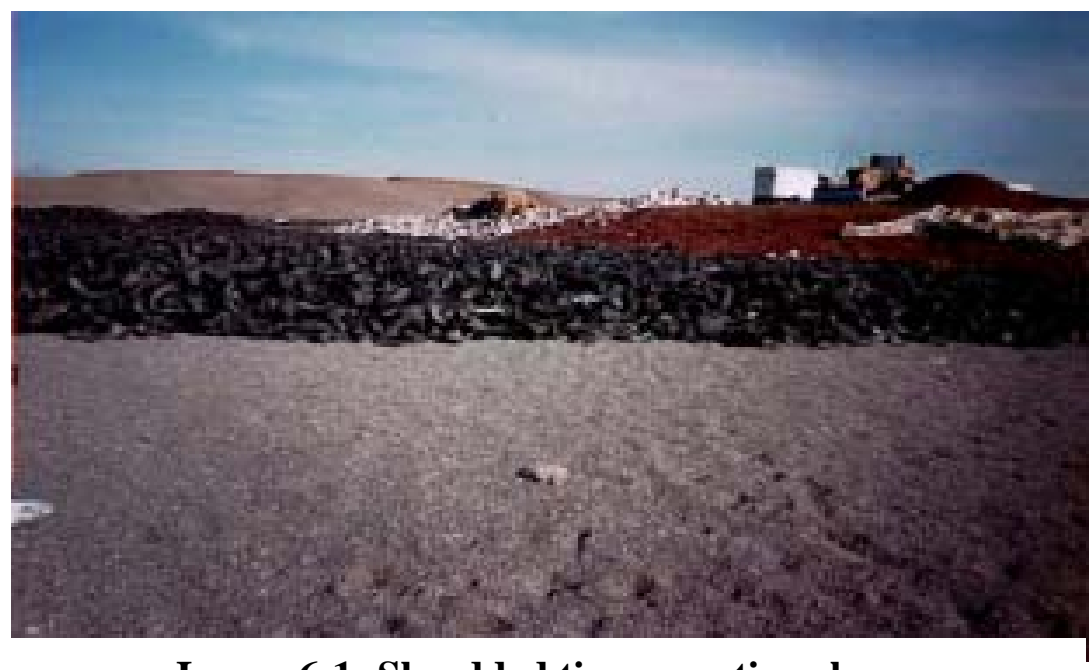

Image 6-1: Shredded tire operations layer 
(HDPE) geomembrane, a 2-foot-thick compacted clay liner $\left(\mathrm{k}<6 \times 10^{-9} \mathrm{~cm} / \mathrm{s}\right), 3$ feet of compacted earth fill ( $\left.<1 \times 10^{-8} \mathrm{~cm} / \mathrm{s}\right)$, a 40-mil HDPE vapor barrier layer, and a clay subgrade with 90-percent (ASTM D1557) relative compaction ${ }^{3}$ (Detail 6-2).

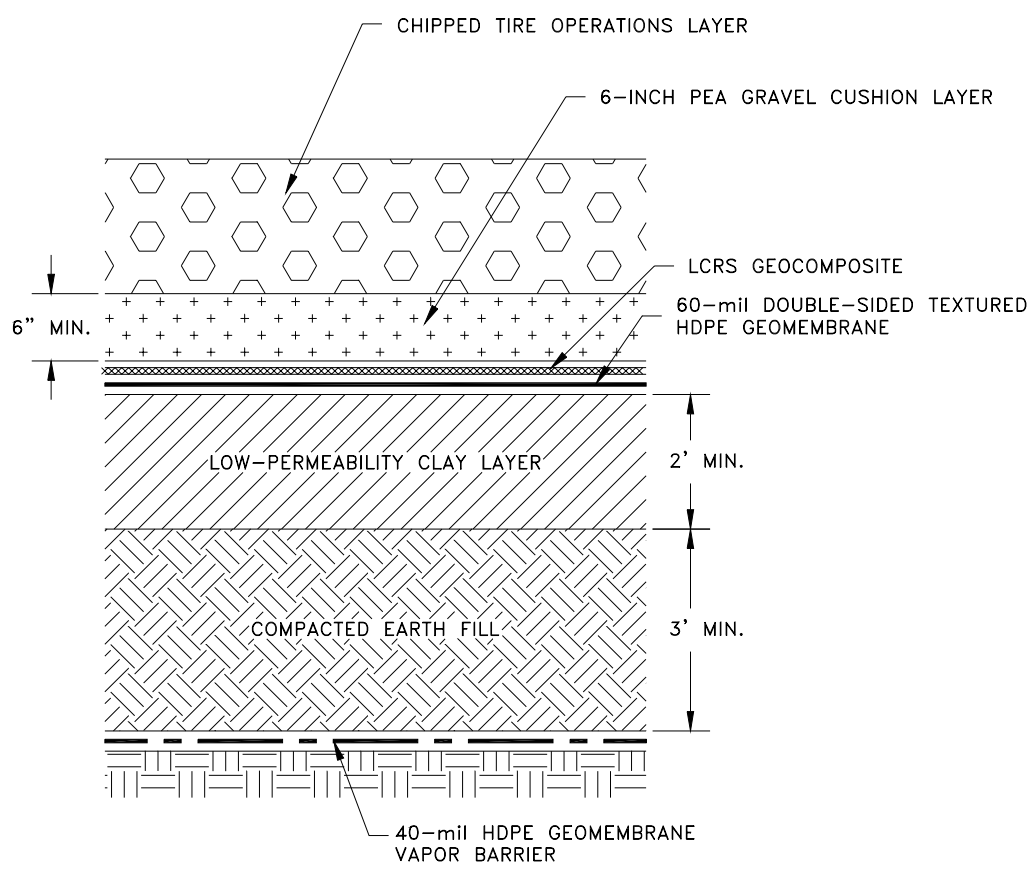

Detail 6-2. Module D Bottom Liner Cross-Section

\subsubsection{Monitoring}

Temperature, moisture, and pressure are monitored through an array of sensors placed within the waste and in the leachate collection and recovery system (LCRS). Each sensor location on the base layer received a temperature sensor (thermistor), a linear low-density polyethylene (LLDPE) tube, and selected locations received a PVC moisture sensor. For protection, each wire and tube was encased in either a 1.25-inch HDPE pipe or run inside the LFG collection piping. Refer to Appendix B, Detail 6-3 for sensor location diagram.

Sensors installed on the primary liner (prior to any waste placement) were placed on geocomposite and covered with pea gravel prior to the placement of the chipped tire operations layer. A summary of sensors installed on the base liner is provided in Appendix A, Table 6-1.

As part of the requirements specified under Waste Discharge Requirements in Order 5-00-134, Yolo County is required to monitor liquid buildup on the liner. Under typical landfilling, liquid buildup on a Class III composite liner system must be maintained to less than 1 foot. In order to gain approval from the California Regional Water Quality Control Board to operate Module 6D as a bioreactor, Yolo County must maintain less than 4-inches of liquid buildup on the Module $6 \mathrm{D}$ primary liner ${ }^{4}$. Head over the liner is monitored through a series of pressure transducers and sampling tubes either in or next to the leachate collection trenches (Appendix C, Figure 6-10). In

\footnotetext{
${ }^{3}$ Golder Associates, "Final Report, Construction Quality Assurance, Yolo County Central Landfill, WMU 6, Module D, Phase 1 Expansion”, December 1999.

${ }^{4}$ California Regional Water Quality Control Board, Central Valley Region, "Waste Discharge Requirements for the Yolo County Central Landfill, No. 5-00-134”, June 16, 2000.
} 
addition, sampling tubes located on the Module 6D liner (designations 0-1 through 0-66) are utilized to monitor head over the liner.

\subsubsection{Temperature}

Temperature is monitored with thermistors manufactured by Quality Thermistor, Inc. Thermistors with a temperature range of $0^{\circ} \mathrm{C}$ to $100^{\circ} \mathrm{C}$ were chosen to accommodate the temperature ranges expected in both the anaerobic and aerobic cells. To prevent corrosion, each thermistor was encased in epoxy and set in a stainless steel sleeve. All field wiring connections were made by first soldering the connection, then covering each solder joint with adhesive-lined heat shrink tubing, and then encasing the joint in electrical epoxy. Changes in temperature are measured by the change in thermistor resistivity (ohms). As temperature increases, thermistor resistance decreases.

\subsubsection{Moisture}

Moisture levels are measured with polyvinyl chloride (PVC) moisture sensors and gypsum blocks. Both the PVC moisture sensors and gypsum blocks are read utilizing the same meter. The PVC sensors are perforated 2-inch-diameter PVC pipes with two stainless steel screws spaced 8 inches apart and attached to wires to form a circuit that includes the gravel filled pipe. The PVC sensors were designed by Yolo County and used successfully during the pilot scale project. The PVC moisture sensor can provide a general, qualitative assessment of the waste's moisture content. A reading of 0 to 40 equates to no free liquid, 40 to 80 equates to some free liquid, and 80 to 100 means completely saturated conditions.

\subsubsection{Leachate Collection Trenches}

Three LLDPE sampling tubes were installed in each of the leachate collection trenches (Image 62). The tubes were installed inside a 2-inch-diameter PVC pipe for protection, and terminate at different points along the trenches. The sampling tubes can be hooked up to the same "Magnahelic" pressure gage, which reads directly in inches-of-water.

Pressure transducers were installed at three locations adjacent to each leachate collection trench. Additionally, tubes were installed that terminate adjacent to each of the pressure transducer locations (Appendix B. Detail 6-2). The pressure transducers provide an output current between 4 and 20 milliamps, which is directly proportional to pressure. The pressure transducers installed on the Module 6D liner are Model PTX 1830 manufactured by Druck, Inc. Their pressure range is 0 to 1 pounds per square inch (psi) and has +0 an accuracy of \pm 1 percent of full scale. 


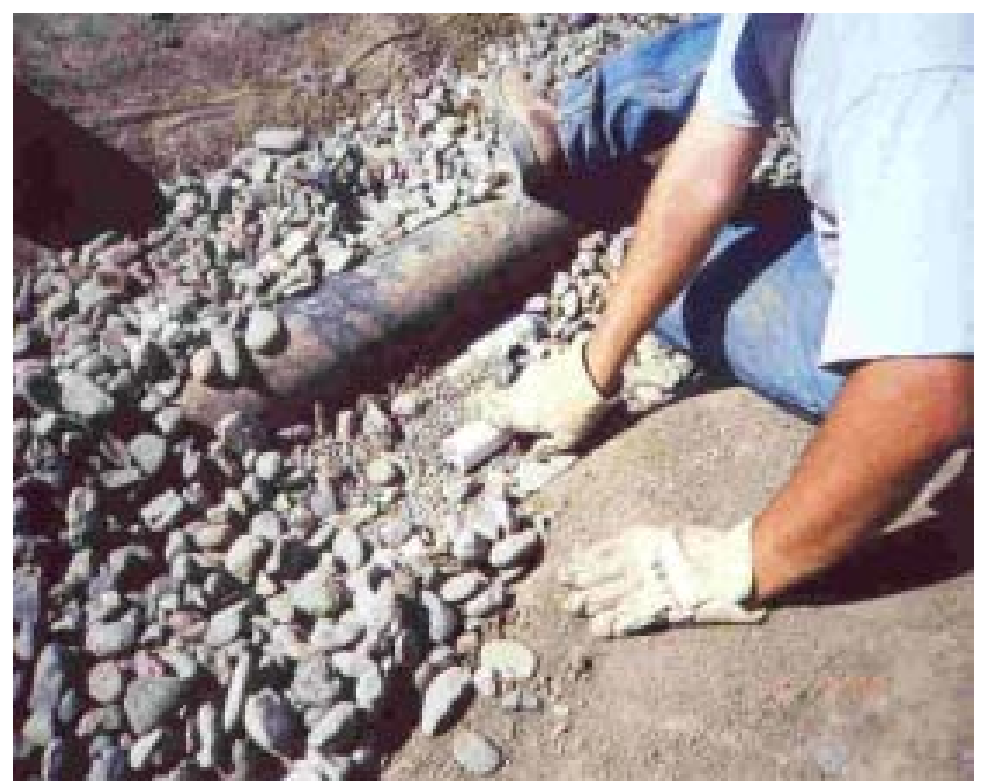

Image 6-2: Pressure tubes installed in LCRS trench

\subsection{Results And Discussion}

Tubes located in the leachate collection trenches are referred to as trench liquid level (TLL) tubes. Pressure transducers and their accompanying tubes that are located adjacent to the leachate collection trenches are denoted as PT or PT-TUBE respectively.

\subsubsection{Temperature}

Temperature is monitored with thermistors manufactured by Quality Thermistor, Inc. Thermistors with a temperature range of $0^{\circ} \mathrm{C}$ to $100^{\circ} \mathrm{C}$ were chosen so they would be able to accommodate the temperature ranges expected in both the anaerobic and aerobic cells. Resistance was measured by the SCADA system located in the instrumentation shed starting in March 2002. Resistance was previously measured manually by connecting the sensor wires to a 26 III Multimeter manufactured by Fluke Corporation.

Temperature results are presented in Appendix C, Figures 6-1 to 6-4. A summary of the results is presented below in Table 6-1 and Figure 6-5.

Table 6-1. Temperature Summary for the Base Liner

\begin{tabular}{|c|c|c|c|c|c|c|}
\hline & \multicolumn{3}{|c|}{$\begin{array}{c}\text { Previous Reporting Period } \\
(1 \mathbf{1} / \mathbf{0 2 - 1 2 / 3 1 / 0 2})\end{array}$} & \multicolumn{3}{c|}{$\begin{array}{c}\text { Current Reporting Period } \\
(\mathbf{0 1 / 0 1 / 0 3} \text { to 03/31/03) }\end{array}$} \\
\hline Location & $\begin{array}{c}\text { Minimum } \\
\text { Temp. }\left({ }^{\circ} \mathbf{C}\right)\end{array}$ & $\begin{array}{c}\text { Maximum } \\
\text { Temp. }\left({ }^{\circ} \mathbf{C}\right)\end{array}$ & $\begin{array}{c}\text { Average } \\
\text { Temp. }\left({ }^{\circ} \mathbf{C}\right)\end{array}$ & $\begin{array}{c}\text { Minimum } \\
\text { Temp. }\left({ }^{\circ} \mathbf{C}\right)\end{array}$ & $\begin{array}{c}\text { Maximum } \\
\text { Temp. }\left({ }^{\circ} \mathbf{C}\right)\end{array}$ & $\begin{array}{c}\text { Average } \\
\text { Temp. }\left({ }^{\circ} \mathbf{C}\right)\end{array}$ \\
\hline Northwest & 11.3 & 30.6 & 27.3 & 8.2 & 30.1 & 24.0 \\
\hline Southwest & 18.6 & 30.2 & 26.1 & 15.8 & 29.1 & 24.0 \\
\hline Northeast & 13.5 & 29.8 & 24.5 & 12.2 & 30.8 & 25.2 \\
\hline Southeast & 13.0 & 33.5 & 24.1 & 10.2 & 34.5 & 24.1 \\
\hline
\end{tabular}


Figure 6-5. Average Temperatures on the Base Liner

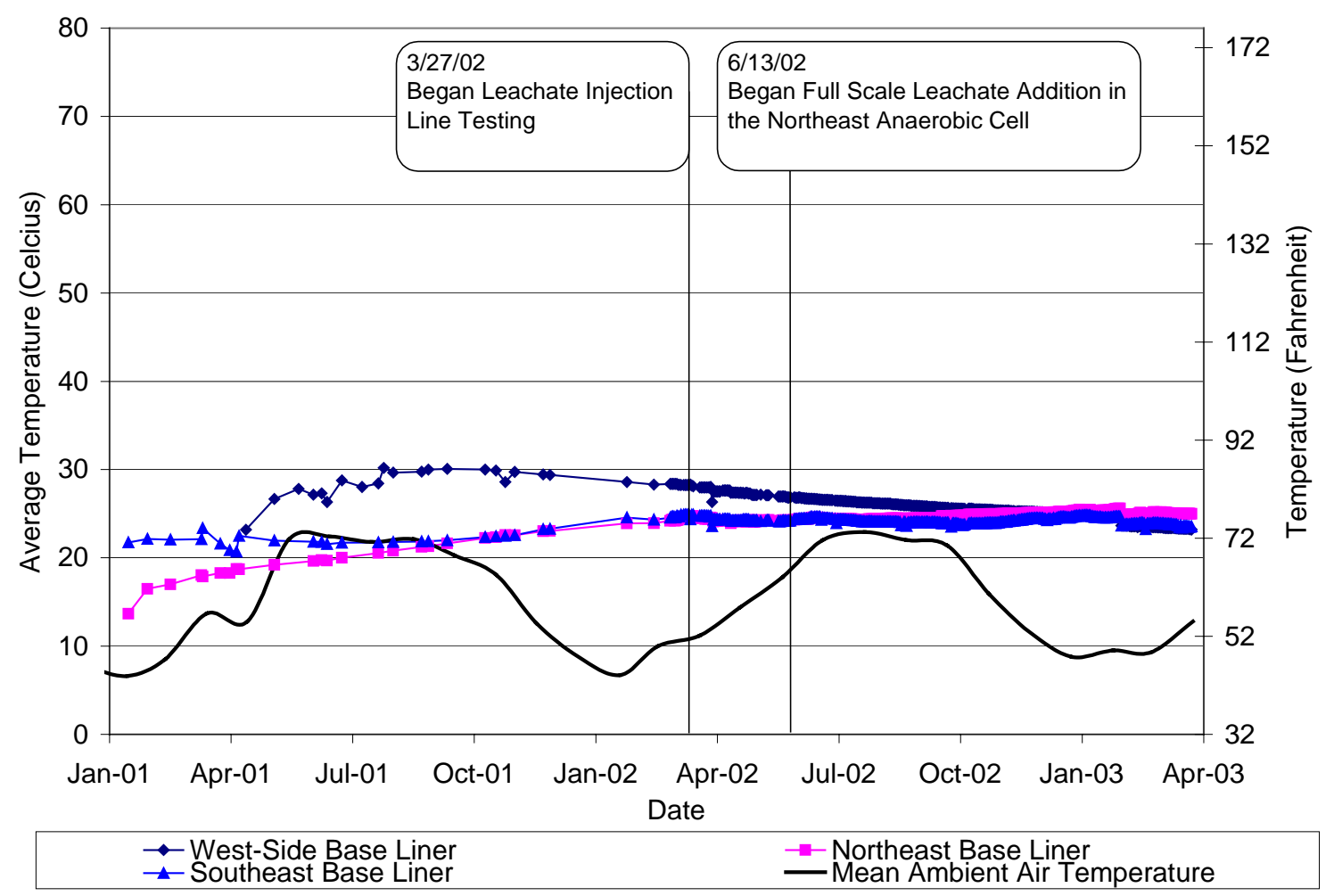

\subsubsection{Moisture}

The SCADA system started electronically measuring moisture in March 2002. Due to a slight variation between how the SCADA system measures moisture compared to the manual meter, moisture readings generally increased a small fraction relative to their previous manually recorded readings. Because moisture data are unitless numbers that give a qualitative assessment rather than a quantitative measure, we feel that this slight change is not significant. Moisture was previously measured manually with a Model MM 4 moisture meter manufactured by Electronics Unlimited. During the pilot scale project, Yolo County conducted laboratory tests with the PVC sensors to determine the relationship between the multimeter readings and the presence of free liquid in the PVC sensor. It was determined that a meter reading of less than 40 corresponded to an absence of free liquid. A reading between 40 and 80 corresponds to the presence of free liquid in the PVC pipe but less than saturated conditions. Readings of greater than 80 indicate saturated conditions; i.e. the PVC sensor is full of liquid.

Moisture results are presented in Appendix C, Figures 6-6 to 6-8. A summary of the results is presented below in Table 6-2 and in Figure 6-9. 
Table 6-2. PVC Moisture Summary for the Base Liner

\begin{tabular}{|c|c|c|c|c|c|c|}
\hline & \multicolumn{3}{|c|}{$\begin{array}{c}\text { Previous Reporting Period } \\
(10 / 1 / 02\end{array}$} & \multicolumn{3}{c|}{$\begin{array}{c}\text { Current Reporting Period } \\
(\mathbf{0 1 / 0 1 / 0 3} \text { to 03/31/03) }\end{array}$} \\
\hline Location & $\begin{array}{c}\text { Minimum } \\
\text { Moisture }\end{array}$ & $\begin{array}{c}\text { Maximum } \\
\text { Moisture }\end{array}$ & $\begin{array}{c}\text { Average } \\
\text { Moisture }\end{array}$ & $\begin{array}{c}\text { Minimum } \\
\text { Moisture }\end{array}$ & $\begin{array}{c}\text { Maximum } \\
\text { Moisture }\end{array}$ & $\begin{array}{c}\text { Average } \\
\text { Moisture }\end{array}$ \\
\hline West-Side & 4.0 & 19.9 & 6.3 & 6.5 & 20.3 & 9.2 \\
\hline Northeast & 22.3 & 94.4 & 42.5 & 26.6 & 88.2 & 47.5 \\
\hline Southeast & 8.3 & 88.2 & 48.2 & 8.8 & 88.2 & 48.9 \\
\hline
\end{tabular}

Figure 6-9. Average Moisture Levels on the Base Liner

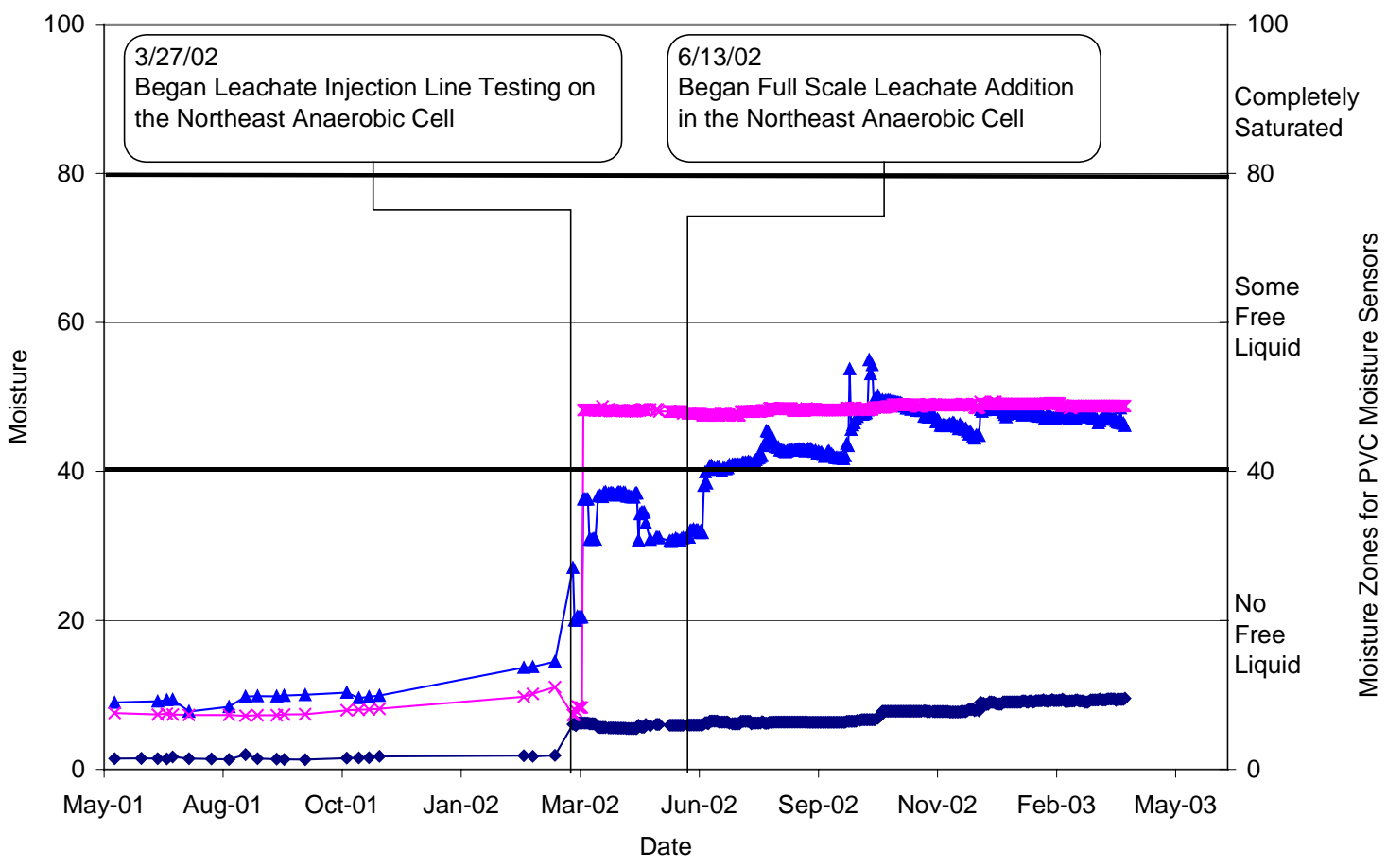

$$
\rightarrow \text { West-Side Base Liner } \quad \rightarrow \text { Northeast Base Liner } \quad * \text { Southeast Base Liner }
$$

\subsubsection{Leachate Collection Trenches}

Liquid level data adjacent to the leachate collection trenches is presented in Appendix C, Figure 6-10. Pressure transducers three and four shows increasing liquid levels that are not supported by data from other sensors. During the next quarter, pressure transducers three and four will be removed and tested. A summary of the results is presented below in Table 6-3. 
Table 6-3. Leachate Level Summary for the Base Liner

\begin{tabular}{|c|c|c|c|c|c|c|}
\hline & \multicolumn{3}{|c|}{$\begin{array}{c}\text { Previous Reporting Period } \\
(\mathbf{1 0 / 0 1 / 0 2} \text { to 12/31/02) }\end{array}$} & \multicolumn{3}{c|}{$\begin{array}{c}\text { Current Reporting Period } \\
\text { (01/01/03 to 03/31/03) }\end{array}$} \\
\hline $\begin{array}{c}\text { Pressure } \\
\text { Transducer }\end{array}$ & $\begin{array}{c}\text { Min. Level } \\
\text { (In. of Water) }\end{array}$ & $\begin{array}{c}\text { Max. Level } \\
\text { (In. of Water) }\end{array}$ & $\begin{array}{c}\text { Avg. Level } \\
\text { (In. of Water) }\end{array}$ & $\begin{array}{c}\text { Min. Level } \\
\text { (In. of Water) }\end{array}$ & $\begin{array}{c}\text { Max. Level } \\
\text { (In. of Water) }\end{array}$ & $\begin{array}{c}\text { Avg. Level } \\
\text { (In. of Water) }\end{array}$ \\
\hline 1 & 0.25 & 0.34 & 0.31 & 0.22 & 0.40 & 0.30 \\
\hline 2 & 0.26 & 0.43 & 0.28 & 0.32 & 0.62 & 0.46 \\
\hline 3 & 0.95 & 1.99 & 0.95 & 1.4 & 2.02 & 1.85 \\
\hline 4 & 0.00 & 0.22 & 0.11 & 0.01 & 1.55 & 0.43 \\
\hline 5 & 0.31 & 0.47 & 0.39 & 0.29 & 0.48 & 0.37 \\
\hline 6 & 0.00 & 0.16 & 0.14 & 0.01 & 0.15 & 0.04 \\
\hline
\end{tabular}

\section{SUPERVISORY CONTROL AND DATA ACQUISITION SYSTEM (SCADA)}

The Supervisory Control and Data Acquisition (SCADA) system is used to monitor the various sensors and control the operation of the bioreactor. The field electronics are linked by radio signal to a computer located in our Woodland office.

\subsection{Hardware Installation}

The data collection hardware has been installed in a shed located at the southern limit of Module 6D. All instrumentation installed in the northeast anaerobic, west-side anaerobic, aerobic, and on the Module 6D composite liner will be connected to an Allen-Bradley central processor which is radio linked to a computer located in our woodland office.

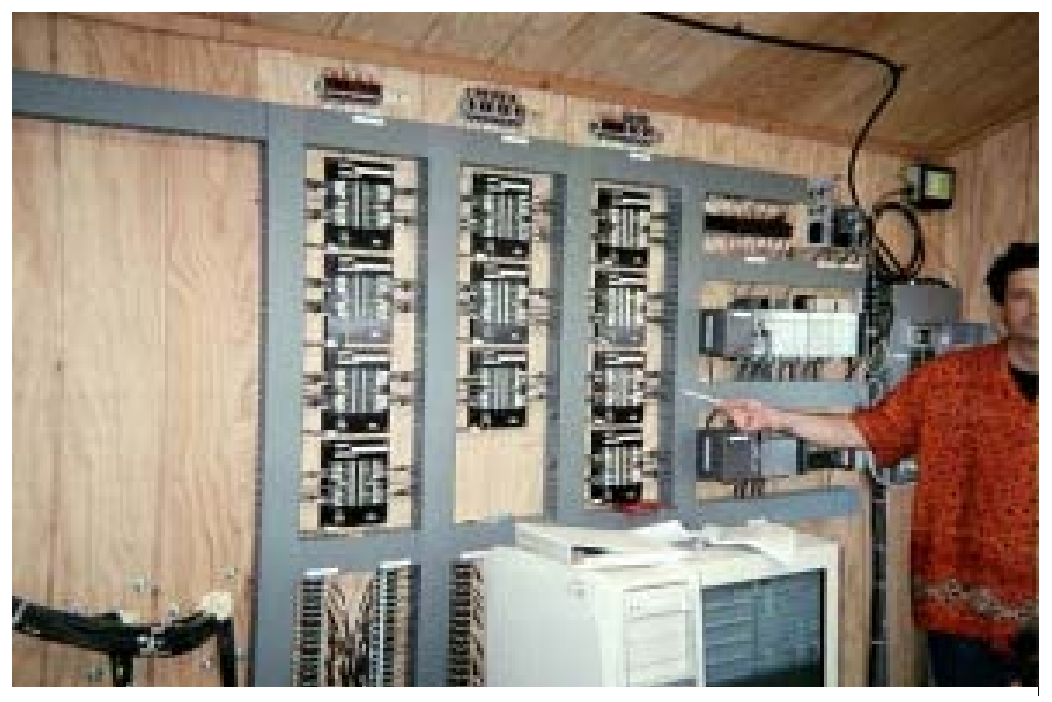

Image 7-1: Completed hardware installation

\subsection{Software Programming}

The SCADA programming using Wonderware software is currently being developed by a consultant, A-TEEM Electrical Engineering. The first phase of the software development is 
complete and encompasses data collection from the instrumentation installed on the Module 6D liner, northeast anaerobic, and south

east aerobic modules. Once the remaining instrumentation in the west-side anaerobic cell has been run the shed, it will be incorporated into the system. The following images provide an overview of the SCADA programming.

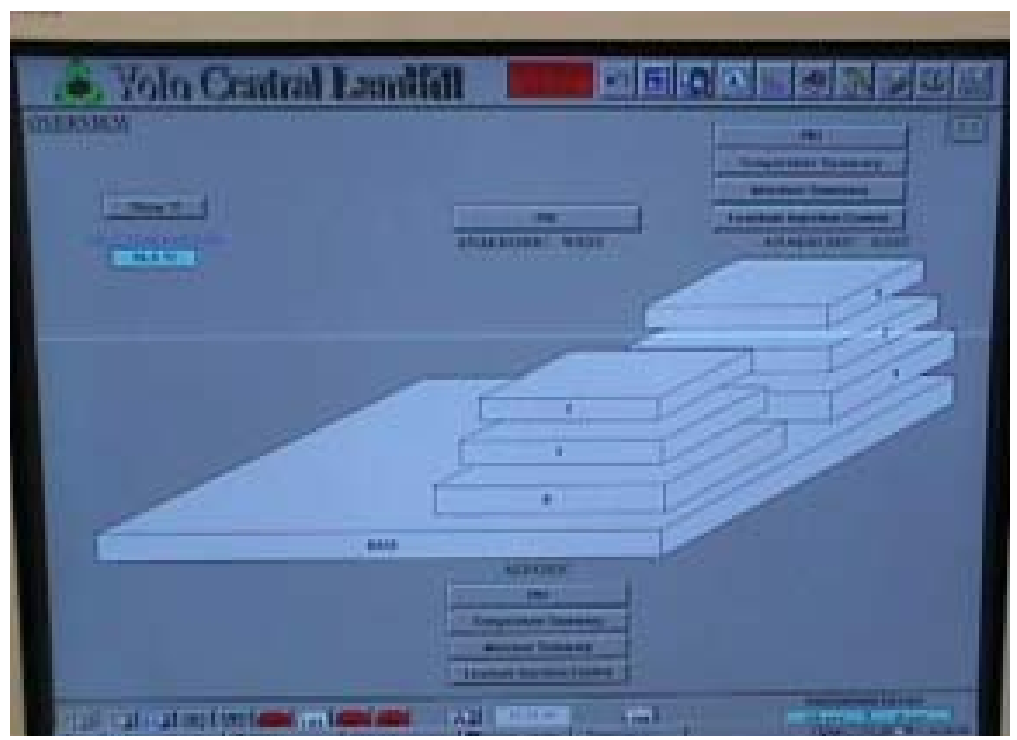

Image 7-2: SCADA overview screen. From here you can access each layer within the bioreactor cells.

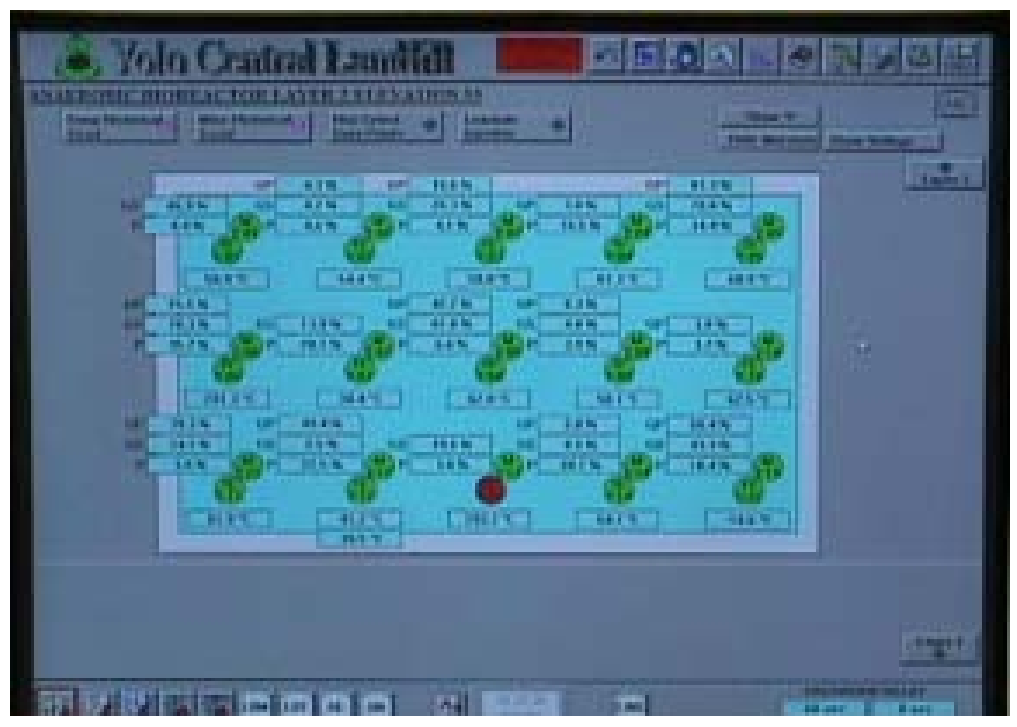

Image 7-3: NE anaerobic cell, layer 2 screen depicting temperature and moisture data. 


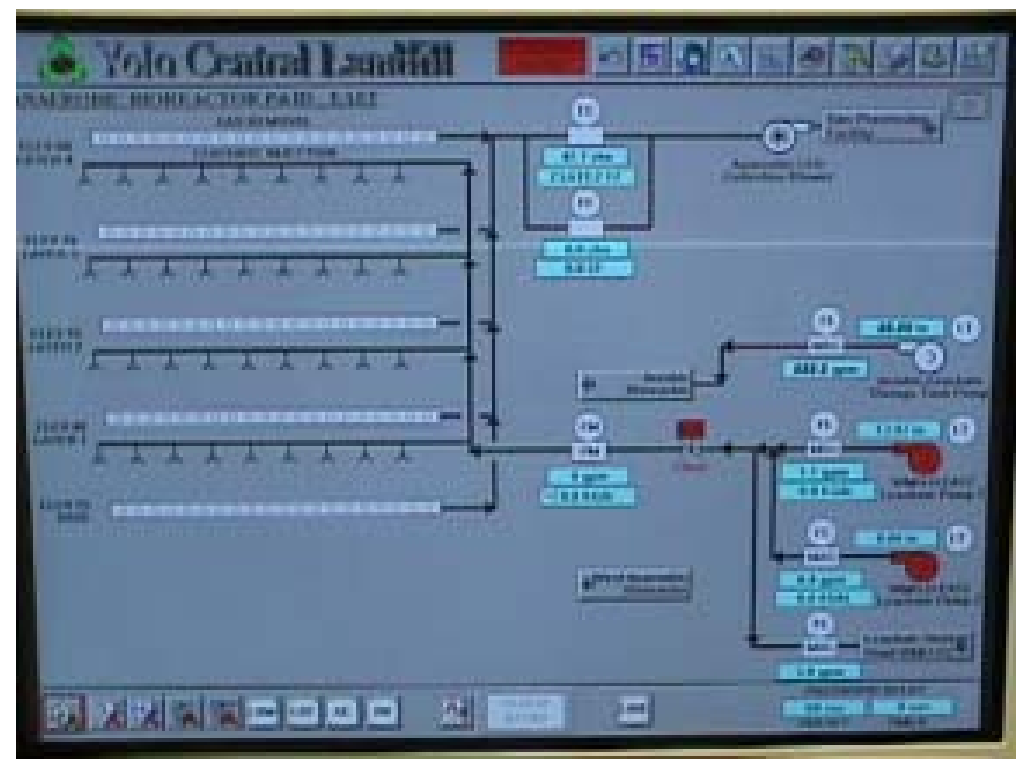

Image 7-4: Piping overview screen, displaying flows from the various meters. This screen can also be used to access leachate injection controls.

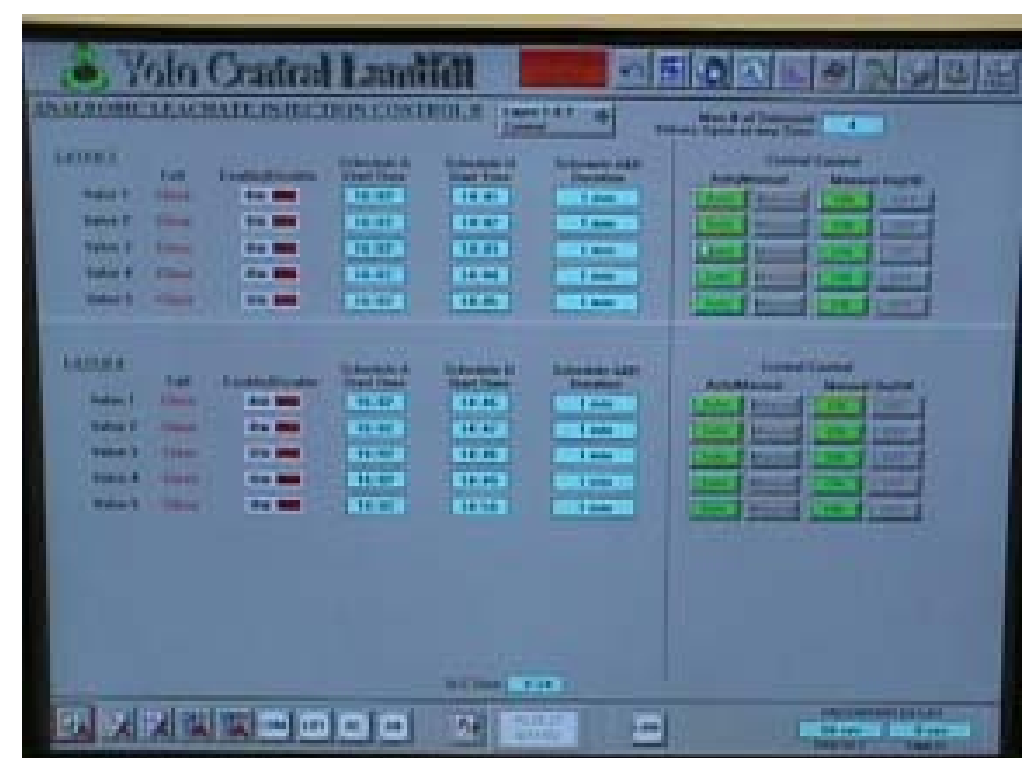

Image 7-5: NE anaerobic bioreactor layer 3 and 4 leachate injection control. 


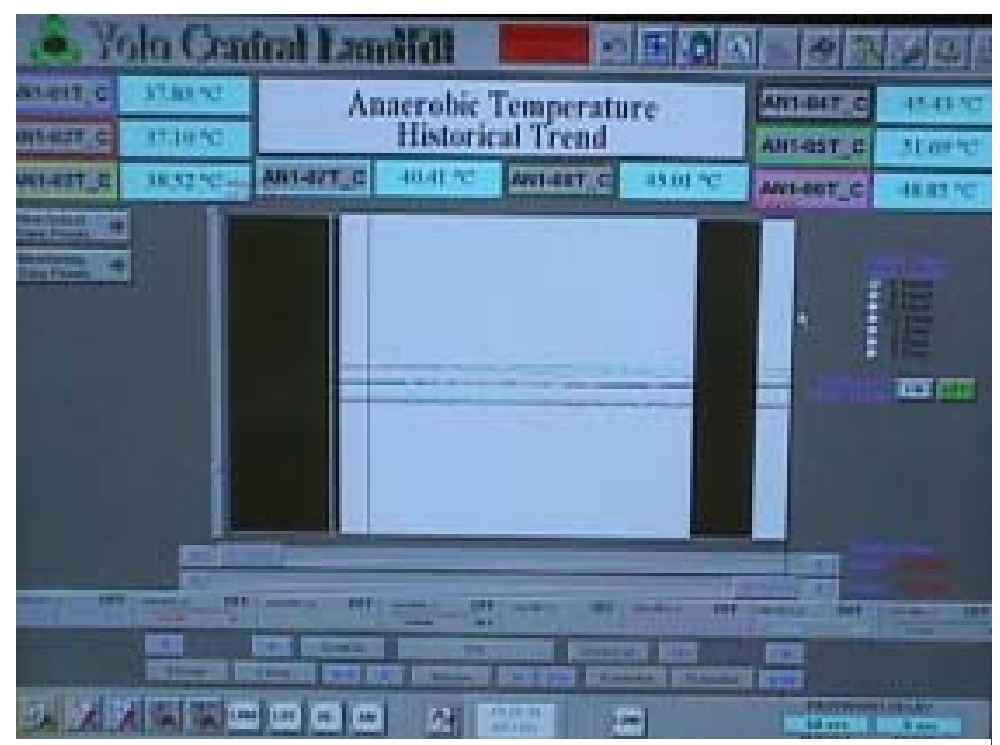

Image 7-6: Historical data can be graphed and displayed directly on the screen.

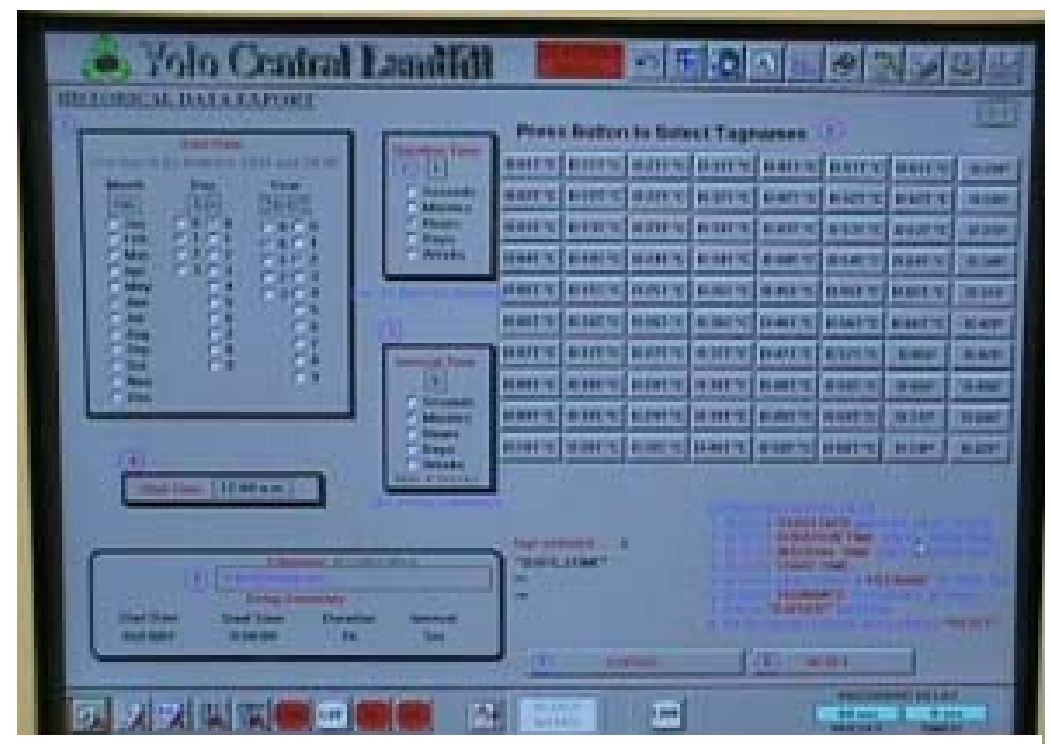

Image 7-7: Historical data export screen. Data is exported to a database for manipulation and graphing 


\section{CONCLUSION}

With the construction complete, and full-scale operation underway, the response of the northeast anaerobic cell is generally as expected. Moisture sensors are indicating that injected liquid is being distributed relatively uniformly. Temperatures within the cell are normal and within the range necessary for anaerobic decomposition.

Gas production has steadily increased over time (and we expect it to continue to increase over the next year). Methane totaling $22.3 \times 10^{6} \mathrm{scf}$ has been removed from 65,104 tons of waste in the northeast cell and $5.3 \times 10^{6} \mathrm{scf}$ has been removed from 166,294 tons of waste in the west-side cell. VOC levels within the landfill gas from the northeast cell have decreased and surface emissions from the module are virtually non-existent.

Fugitive surface emissions from the aerobic cell remain extremely low. Because liquid addition has not commenced in the aerobic cell, its full potential at eliminating fugitive surface emissions has yet to be evaluated. Additionally, methane surface emissions (minus background readings) from the northeast 3.5-acre cell are extremely low, and essentially negligible. Two major items that are responsible for this effective control of surface emissions are the following: 1) The installation of a synthetic cover over the entire cell, and 2) The use of an active landfill gas extraction system. Higher methane emissions have been detected from the west-side anaerobic cell. These emissions are attributed to the west-side cell undergoing waste placement during the surface scans performed from June 2002 to September 2002 and emissions due to unsealed areas were piping penetrates the surface liner. We expect to detect lower fugitive surface emissions in the future due to the completion of the gas extraction system.

Final construction of the aerobic blower facilities continued during this reporting period. The components of the aerobic blower station have been installed and the electrical work associated with the blower station have been completed. Installation of piping from the blower station to the biofilter began in February 2003 and construction of the biofilter is scheduled to begin in April 2003. 


\section{REFERENCES}

1. Vector Engineering, "Design Report for the Surface Liners of the Module D Phase 1 Bioreactors at the Yolo County Central Landfill", October 2001.

2. Yazdani, R., Moore, R. Dahl. K. and D. Augenstein 1998 Yolo County Controlled Landfill Bioreactor Project. Yolo County Public Works and I E M, Inc. Yolo County Public Works and I E M, Inc. report to the Urban Consortium Energy Foundation (UCETF) and the Western Regional Biomass Energy Program, USDOE.

3. Golder Associates, "Final Report, Construction Quality Assurance, Yolo County Central Landfill, WMU 6, Module D, Phase 1 Expansion”, December 1999.

4. California Regional Water Quality Control Board, Central Valley Region, "Waste Discharge Requirements for the Yolo County Central Landfill, No. 5-00-134”, June 16, 2000.

5. Yolo County, IEM, SWANA, EPA, Final Project Agreement for the Yolo County Accelerated Anaerobic and Aerobic Composting (Bioreactor) Project, September 14, 2000.

6. Tchobanoglous et al, "Integrated Solid Waste Management, Engineering Principles and management Issues”, McGraw-Hill, 1993. 
APPENDIX A - EPA XL SCHEDULE AND SUMMARY OF MATERIALS INSTALLED 
Table 1-1. Revised Project XL Delivery Schedule

\begin{tabular}{|c|c|}
\hline Project Task & Delivery Date \\
\hline - RWQCB approved the revised Waste Discharge Requirement Permit & June 22, 2000 \\
\hline - Final draft FPA circulated to stakeholders for comments & June 22,2000 \\
\hline $\begin{array}{ll}\text { - } & \text { Comments received for Final Project Agreement (FPA) } \\
\text { - } & \text { Instrumentation installation began } \\
\end{array}$ & July 3,2000 \\
\hline - Finalize FPA and distribute for signature & July 21,2000 \\
\hline - All parties sign FPA document & September, 2000 \\
\hline - Final Rule for Yolo County XL Project published in Federal Register & August 30, 2001 \\
\hline $\begin{array}{l}\text { First lift of waste completed in the southeast corner of Module 6D. } \\
\text { This lift of waste is to be used as the foundation layer for the aerobic } \\
\text { cell liner. }\end{array}$ & January 2001 \\
\hline - Waste placement begins in the northeast 3.5 acre anaerobic bioreactor & January 2001 \\
\hline - Begin monitoring temperature and moisture of waste & January 2001 \\
\hline $\begin{array}{l}\text { - Begin waste placement in west 6-acre anaerobic cell (waste } \\
\text { placement alternates between the west and northeast anaerobic } \\
\text { bioreactors and the aerobic bioreactor to facilitate placement of } \\
\text { instrumentation, piping, etc.) }\end{array}$ & March 2001 \\
\hline $\begin{array}{l}\text { - Completed construction of aerobic cell liner and begin waste } \\
\text { placement in aerobic cell }\end{array}$ & July 2001 \\
\hline $\begin{array}{l}\text { - Complete the following for the northeast anaerobic } 3.5 \text {-acre cell: } \\
\text { waste placement, instrumentation, leachate injection system, air } \\
\text { injection system, and gas and leachate monitoring }\end{array}$ & September 2001 \\
\hline $\begin{array}{l}\text { - Complete the following for the aerobic bioreactor: waste placement, } \\
\text { instrumentation, data acquisition and control system, leachate } \\
\text { injection system, air management system, gas and leachate } \\
\text { monitoring }\end{array}$ & June 2003 \\
\hline - Begin liquid addition to the northeast 3.5-acre anaerobic cell & November 2001 \\
\hline - Begin liquid addition and air injection in aerobic bioreactor & June 2003 \\
\hline $\begin{array}{l}\text { - Complete the following for the west anaerobic 6-acre cell: waste } \\
\text { placement, instrumentation, data acquisition and control system, } \\
\text { leachate injection system, gas collection system, gas and leachate } \\
\text { monitoring, and cover system }\end{array}$ & October 2002 \\
\hline - Begin liquid injection in the west side 6-acre anaerobic bioreactor & June 2003 \\
\hline - Data collection and reporting will continue & $\begin{array}{l}\text { On-going until waste } \\
\text { stabilization is complete, } \\
\text { but dependent on } \\
\text { sustained funding levels }\end{array}$ \\
\hline
\end{tabular}


Table 3-1. Summary of Data for the Northeast Anaerobic Cell

\begin{tabular}{|c|c|}
\hline Description & Data \\
\hline Footprint & 3.4 acres \\
\hline Average Waste Depth & 35 feet \\
\hline Construction of the Base Liner & 1999 \\
\hline Waste Filling of Cells & $1 / 13 / 2001-8 / 3 / 2001$ \\
\hline Total \# of Waste Lifts & 4 \\
\hline Total Amount of Waste & 65,104 tons \\
\hline Total Amount of Greenwaste ADC ${ }^{1}$ & 11,060 tons \\
\hline Volume of Soil Within the Waste Mass ${ }^{2}$ & 5,970 cubic yards \\
\hline $\begin{array}{l}\text { As-Placed Biodegradable Waste Tonnage }{ }^{3} \\
\text { As-Placed Biodegradable Greenwaste ADC Tonnage }\end{array}$ & $\begin{array}{l}29,600 \text { tons } \\
7,700 \text { tons }\end{array}$ \\
\hline Ratio of Waste to Greenwaste ADC & 5.9 to 1 \\
\hline Ratio of Waste to Greenwaste ADC and Soil & 3.4 to 1 \\
\hline Average Density of Waste & $\begin{array}{l}1,162 \text { pounds per cubic yard, lbs/cy } \\
\text { (does not include soil or ADC) }\end{array}$ \\
\hline $\begin{array}{l}\text { Total \# of Horizontal Gas Collection Lines }{ }^{4} \\
\text { Layer } 1 \\
\text { Layer } 2 \\
\text { Layer } 3 \\
\text { Layer } 4\end{array}$ & $\begin{array}{ll}17 & \text { Spacing of approximately } \\
6 & 40 \text { feet on center } \\
5 & \\
3 & \\
3 & \\
\end{array}$ \\
\hline $\begin{array}{l}\text { Total \# of Liquid Addition Lines (HDPE Pipe) } \\
\text { Layer } 1 \\
\text { Layer } 2 \\
\text { Layer } 3 \\
\text { Layer } 4\end{array}$ & $\begin{array}{ll}25 & \text { Spacing of approximately } \\
8 & 40 \text { feet on center } \\
7 & \\
5 & \\
5 & \\
\end{array}$ \\
\hline $\begin{array}{l}\text { Total Amount of Liquid Addition Piping } \\
\text { Layer } 1 \\
\text { Layer } 2 \\
\text { Layer } 3 \\
\text { Layer } 4 \\
\end{array}$ & $\begin{array}{l}7,990 \text { feet } \\
3,080 \text { feet } \\
2,450 \text { feet } \\
1,500 \text { feet } \\
960 \text { feet }\end{array}$ \\
\hline $\begin{array}{l}\text { Total \# of } 3 / 32 \text { inch Diameter Holes in Injection Line } \\
\text { Layer } 1 \\
\text { Layer } 2 \\
\text { Layer } 3 \\
\text { Layer } 4 \\
\end{array}$ & $\begin{array}{l}337 \\
145 \\
93 \\
55 \\
44\end{array}$ \\
\hline Surface Liner & 36-mil ${ }^{6}$ Reinforced Polypropylene \\
\hline
\end{tabular}

${ }^{1}$ ADC-Alternative Daily Cover

${ }^{2}$ This is an estimate

${ }^{3}$ Calculated using biodegradable fractions from Tchobanoglous et, al. (1993)

${ }^{4}$ Refer to Table 3 for a complete description of gas collection lines

${ }^{5}$ High Density Polyethylene, HDPE

${ }^{6} 1$-mil is equivalent to 0.001 inches and refers to the thickness of the liner 
Table 3-2. Summary of Sensors for the Anaerobic Cells

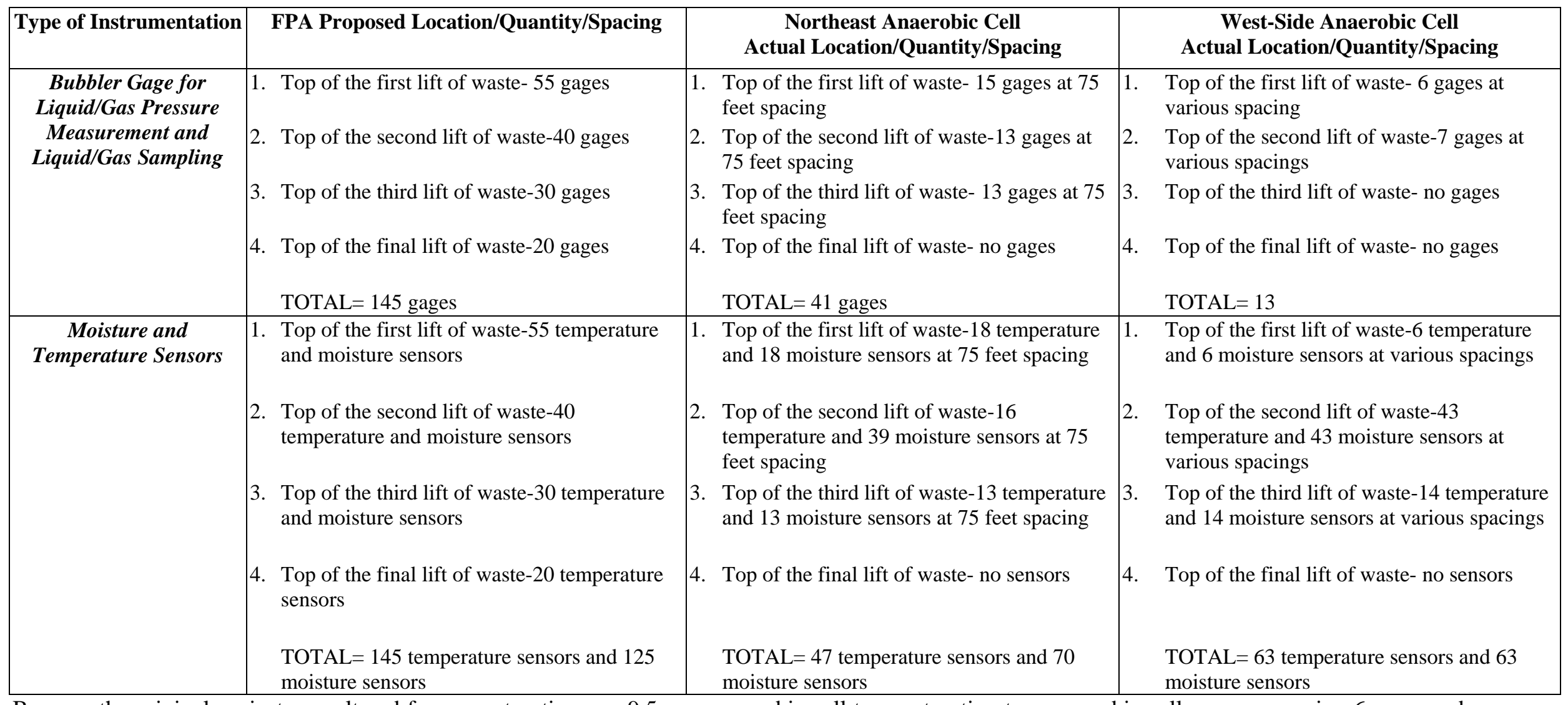

Because the original project was altered from constructing one 9.5-acre anaerobic cell to constructing two anaerobic cells, one occupying 6-acres and one occupying 3.5-acres, waste placement area was lost in the valley separating the two anaerobic cells. This resulted in the installation of fewer sensors over the 9.5 -acre area than initially proposed. 
Table 3-3. Summary of Gas Collection Lines for the Northeast Anaerobic Cell

\begin{tabular}{|c|c|c|}
\hline $\begin{array}{c}\text { Gas } \\
\text { Collection } \\
\text { Line }^{1} \\
\end{array}$ & Description & Spacing \\
\hline 1-G1 & Alternating 4 and 6 inch schedule $80 \mathrm{PVC}^{2}$. & 50' from west toe \\
\hline $1-\mathrm{G} 2$ & $\begin{array}{l}\text { Shredded tires with pipe at ends. The north end is } 40 \text { feet of schedule } 40 \\
\text { PVC with a } 10 \text { foot section of } 3 \text { inch perforated schedule } 80 \text { PVC. The south } \\
\text { end is } 40 \text { feet of } 4 \text { inch schedule } 80 \text { PVC, } 5 \text { feet of } 3 \text { inch schedule } 80 \text { PVC, } \\
\text { and } 10 \text { feet of perforated HDPE. }\end{array}$ & 40' from 1-G1-NE \\
\hline $1-\mathrm{G} 3$ & Alternating 4 and 6 inch schedule 80 PVC. & 40' from 1-G2-NE \\
\hline $1-\mathrm{G} 4$ & $\begin{array}{l}\text { Shredded tires with PVC pipe at ends. The south end is } 40 \text { feet of } 4 \text { inch } \\
\text { schedule } 80 \text { PVC and } 10 \text { feet of } 6 \text { inch schedule } 80 \text { PVC. The north end is } \\
40 \text { feet of } 4 \text { inch schedule } 40 \text { PVC. }\end{array}$ & $40^{\prime}$ from $1-\mathrm{G} 3-\mathrm{NE}$ \\
\hline 1-G5 & $\begin{array}{l}\text { Shredded tires with PVC pipes at ends. The south end is } 40 \text { feet of } 4 \text { inch } \\
\text { schedule } 80 \text { PVC, } 10 \text { feet of } 6 \text { inch schedule } 80 \text { PVC, } 20 \text { feet of } 4 \text { inch } \\
\text { schedule } 80 \text { PVC, and } 5 \text { feet of } 24 \text { inch corrugated HDPE. The north end is } \\
40 \text { feet of } 4 \text { inch schedule } 40 \text { PVC. }\end{array}$ & 40' from $1-\mathrm{G} 4-\mathrm{NE}$ \\
\hline $1-\mathrm{G} 6$ & $\begin{array}{l}\text { Shredded tires with PVC pipes at ends. The south end is } 40 \text { feet of } 4 \text { inch } \\
\text { schedule } 80 \text { PVC, } 20 \text { feet of } 3 \text { inch perforated schedule } 80 \text { PVC, } 10 \text { feet of } 6 \\
\text { inch schedule } 80 \text {, and } 20 \text { feet of } 3 \text { inch perforated schedule } 80 \text { PVC. The } \\
\text { north end is } 40 \text { feet of } 4 \text { inch schedule } 40 \text { PVC. }\end{array}$ & 40' from $1-\mathrm{G} 5-\mathrm{NE}$ \\
\hline 2-G1 & $\begin{array}{l}\text { Shredded tires with PVC pipes at ends. The south end is } 40 \text { feet of } 4 \text { inch } \\
\text { schedule } 80,10 \text { feet of } 6 \text { inch schedule } 80 \text {, and } 10 \text { feet of } 4 \text { inch schedule } 80 \\
\text { PVC. The north end is } 40 \text { feet of } 4 \text { inch schedule } 40 \text { PVC. }\end{array}$ & 30 ' from West toe \\
\hline $2-\mathrm{G} 2$ & $\begin{array}{l}\text { Alternating } 4 \text { and } 6 \text { inch schedule } 80 \text { PVC pipe for the entire length with } 40 \\
\text { feet of } 4 \text { inch at the north and south end. }\end{array}$ & $40^{\prime}$ from 2-G1-NE \\
\hline 2-G3 & $\begin{array}{l}\text { Shredded tires with PVC pipe at the ends. The north end is } 40 \text { feet of } 4 \text { inch } \\
\text { schedule } 40 \text { PVC. The south end } 40 \text { feet of } 4 \text { inch schedule } 80 \text { PVC, } 20 \text { feet } \\
\text { of } 3 \text { inch schedule } 80 \text { PVC, } 10 \text { feet of } 6 \text { inch schedule } 80 \text { PVC, and } 20 \text { feet } 3 \\
\text { inch perforated schedule } 80 \text { PVC. }\end{array}$ & $40^{\prime}$ from $2-\mathrm{G} 2-\mathrm{NE}$ \\
\hline $2-\mathrm{G} 4$ & $\begin{array}{l}\text { Alternating } 6 \text { and } 3 \text { inch schedule } 80 \text { PVC pipe. The south end is } 4 \text { inch } \\
\text { schedule } 80 \text { PVC and the north end is } 4 \text { inch schedule } 40 \text { PVC. }\end{array}$ & $40^{\prime}$ from $2-\mathrm{G} 3-\mathrm{NE}$ \\
\hline 2-G5 & $\begin{array}{l}\text { Shredded tires with pipe at the ends. The north end is } 40 \text { feet of } 4 \text { inch } \\
\text { schedule } 40 \text { PVC. The south end is } 40 \text { feet of } 4 \text { inch schedule } 80 \text { PVC, } 20 \\
\text { feet of } 3 \text { inch schedule } 80 \text { PVC, } 20 \text { feet of } 4 \text { inch schedule } 80 \text { PVC, and } 10 \\
\text { feet of } 12 \text { inch corrugated } \text { HDPE }^{3} \text {. }\end{array}$ & $40^{\prime}$ from 2-G4-NE \\
\hline $3-\mathrm{G} 1$ & $\begin{array}{l}\text { Shredded tires with PVC pipe at the ends. The north end is } 40 \text { feet of } 4 \text { inch } \\
\text { schedule } 40 \text { PVC. The south end is } 40 \text { feet } 4 \text { inch schedule } 80 \text { and } 20 \text { feet of } \\
8 \text { inch schedule } 40 \text {. }\end{array}$ & 45 ' from west toe \\
\hline $3-\mathrm{G} 2$ & $\begin{array}{l}\text { Shredded tires with PVC pipe at the ends. The north end is } 40 \text { feet of } 4 \text { inch } \\
\text { schedule } 40 \text { VC. The south end is } 40 \text { feet of } 4 \text { inch schedule } 80 \text { PVC, } 20 \\
\text { feet of } 8 \text { inch HDPE, and } 40 \text { feet of } 6 \text { inch HDPE. }\end{array}$ & $45^{\prime}$ from 3-G1-NE \\
\hline $3-\mathrm{G} 3$ & $\begin{array}{l}\text { Shredded tires with PVC pipe at the ends. The north end is } 40 \text { feet of } 4 \text { inch } \\
\text { schedule } 40 \text { PVC. The south end is } 40 \text { feet of } 4 \text { inch schedule } 80 \text { PVC, } 20 \\
\text { feet of } 6 \text { inch schedule } 40 \text { PVC, and } 10 \text { feet of } 12 \text { inch corrugated HDPE. }\end{array}$ & $35^{\prime}$ from $3-\mathrm{G} 2-\mathrm{NE}$ \\
\hline
\end{tabular}

${ }^{\mathrm{T}}$ Gas Collection Line Nomenclature: Layer \# - G (for gas) and gas line \#

${ }^{2}$ Polyvinyl chloride, PVC

${ }^{3}$ High Density Polyethylene, HDPE 
Table 4-1. Summary of Data for the West-Side Anaerobic Cell

\begin{tabular}{|c|c|}
\hline Description & Data \\
\hline Footprint & 6 acres \\
\hline Average Waste Depth & 35 feet \\
\hline Construction of the Base Liner & 1999 \\
\hline Waste Filling of Cells & $3 / 8 / 2001-8 / 31 / 2002$ \\
\hline Total \# of Waste Lifts & 4 \\
\hline Total Amount of Waste & 166,294 tons \\
\hline Total Amount of Greenwaste ADC ${ }^{1}$ & 27,570 tons \\
\hline $\begin{array}{l}\text { Total \# of Horizontal Gas Collection Lines }{ }^{2} \\
\text { Layer } 1 \\
\text { Layer } 2 \\
\text { Layer } 3 \\
\text { Layer } 4\end{array}$ & $\begin{array}{ll}18 & \text { Spacing of approximately } \\
0 & 80 \text { feet on center } \\
9 & \text { (Layer } 4 \text { spacing of } \\
7 & \text { approximately } 50 \text { feet) } \\
2 & \\
\end{array}$ \\
\hline $\begin{array}{l}\text { Total \# of Liquid Addition Lines (HDPE Pipe) } \\
\text { Layer } 1 \\
\text { Layer } 2 \\
\text { Layer } 3 \\
\text { Layer } 4\end{array}$ & $\begin{array}{ll}27 & \text { Spacings vary } \\
0 & \\
17 & \\
7 & \\
3 & \\
\end{array}$ \\
\hline $\begin{array}{l}\text { Total Amount of Liquid Addition Piping } \\
\text { Layer } 1 \\
\text { Layer } 2 \\
\text { Layer } 3 \\
\text { Layer } 4\end{array}$ & $\begin{array}{l}7,185 \text { feet } \\
0 \text { feet } \\
4,350 \text { feet } \\
1,185 \text { feet } \\
1,650 \text { feet }\end{array}$ \\
\hline $\begin{array}{l}\text { Total \# of } 3 / 32 \text { and } 1 / 8 \text { inch Diameter Holes in Injection Line } \\
\text { Layer } 1 \\
\text { Layer } 2 \\
\text { Layer } 3 \\
\text { Layer } 4\end{array}$ & $\begin{array}{l}321 \\
0 \\
122 \\
62 \\
137 \\
\end{array}$ \\
\hline Surface Liner & 40-mil ${ }^{4}$ LLDPE $^{5}$ geomembrane \\
\hline $\begin{array}{l}\text { ADC-Alternative Daily Cover } \\
{ }^{1} \text { Refer to Table } 3 \text { for a complete description of gas collection } 1 \\
3 \text { High Density Polyethylene, HDPE } \\
{ }^{4} 1 \text {-mil is equivalent to } 0.001 \text { inches and refers to the thickness } \\
5 \text { Linear Low Density Polyproplyene }\end{array}$ & e liner \\
\hline
\end{tabular}


Table 4-2. Summary of Gas Collection Lines for the West-Side Anaerobic Cell

\begin{tabular}{|c|c|c|}
\hline $\begin{array}{c}\text { Gas } \\
\text { Collection } \\
\text { Line }^{1}\end{array}$ & Description & Spacing \\
\hline $2-\mathrm{G} 1$ & $\begin{array}{l}\text { Shredded tires with pipe at ends. The east end is } 45 \text { feet of } 4 \text { inch schedule } 80 \mathrm{PVC}^{2}, 10 \text { feet of } 6 \\
\text { inch schedule } 80 \mathrm{PVC} \text {, and } 10 \text { feet of } 4 \text { inch schedule } 80 \text { PVC. The west end is } 50 \text { feet of } 4 \text { inch } \\
\text { schedule } 80 \text { PVC, } 10 \text { feet of } 6 \text { inch schedule } 80 \text { PVC, and } 10 \text { feet of } 4 \text { inch schedule } 80 \text { PVC. }\end{array}$ & $80^{\prime}$ from 2-G2 \\
\hline $2-\mathrm{G} 2$ & $\begin{array}{l}\text { Shredded tires with pipe at ends. The east end is } 40 \text { feet of } 4 \text { inch schedule } 40 \text { PVC, } 10 \text { feet of } 6 \\
\text { inch schedule } 80 \text { PVC, and } 10 \text { feet of } 4 \text { inch schedule } 80 \text { PVC. The west end is } 40 \text { feet of } 4 \text { inch } \\
\text { schedule } 40 \text { PVC, } 10 \text { feet of } 6 \text { inch schedule } 80 \text { PVC, and } 10 \text { feet of } 4 \text { inch schedule } 80 \text { PVC. }\end{array}$ & 80 ' from $2-\mathrm{G} 3$ \\
\hline 2-G3 & $\begin{array}{l}\text { Shredded tires with pipe on ends. The east and west ends are } 40 \text { feet of } 4 \text { inch schedule } 80 \text { PVC, } \\
10 \text { feet of } 6 \text { inch schedule } 80 \text { PVC, } 10 \text { feet of } 4 \text { inch schedule } 80 \text { PVC, } 10 \text { feet of } 6 \text { inch schedule } \\
80 \text { PVC, and } 10 \text { feet of } 4 \text { inch schedule } 80 \text { PVC. }\end{array}$ & $80^{\prime}$ from 2-G4 \\
\hline $2-\mathrm{G} 4$ & $\begin{array}{l}\text { Shredded tires with pipe on ends. The east end is } 20 \text { feet of } 4 \text { inch schedule } 80 \text { PVC, } 10 \text { feet of } 6 \\
\text { inch schedule } 80 \text { PVC, } 10 \text { feet of } 4 \text { inch schedule } 80 \text { PVC, } 10 \text { feet of } 6 \text { inch schedule } 80 \text { PVC, } \\
\text { and } 10 \text { feet of } 4 \text { inch schedule } 80 \text { PVC. The west end is } 20 \text { feet of } 4 \text { inch schedule } 80 \text { PVC, } 10 \\
\text { feet of } 6 \text { inch schedule } 80 \text { PVC, } 10 \text { feet of } 4 \text { inch schedule } 80 \text { PVC, } 10 \text { feet of } 6 \text { inch schedule } 80 \\
\text { PVC, } 10 \text { feet of } 4 \text { inch schedule } 80 \text { PVC, and } 20 \text { feet of } 24 \text { inch corrugated metal pipe. }\end{array}$ & $80^{\prime}$ from 2-G5 \\
\hline 2-G5 & $\begin{array}{l}\text { Alternating } 10 \text {-foot lengths of } 4 \text { inch schedule } 40 \text { electrical conduit and } 6 \text { inch corrugated metal. } \\
\text { The east end is } 40 \text { feet of } 4 \text { inch schedule } 40 \text { PVC, } 10 \text { feet of } 6 \text { inch schedule } 80 \text { PVC, and } 10 \text { feet } \\
\text { of } 4 \text { inch schedule } 80 \text { PVC. The west end is } 40 \text { feet of schedule } 80 \text { PVC and } 10 \text { feet of } 6 \text { inch } \\
\text { schedule } 40 \text { electrical conduit. }\end{array}$ & 80' from 2-G6 \\
\hline 2-G6 & $\begin{array}{l}\text { Shredded tires with pipe at ends. The east end is } 40 \text { feet of } 4 \text { inch schedule } 40 \text { PVC, } 10 \text { feet of } 6 \\
\text { inch schedule } 80 \text { PVC, and } 10 \text { feet of } 4 \text { inch schedule } 80 \text { PVC. The west end is } 40 \text { feet of } 4 \text { inch } \\
\text { schedule } 40 \text { PVC, } 10 \text { feet of } 12 \text { inch schedule } 40 \text { PVC, } 10 \text { feet of } 4 \text { inch schedule } 80 \text { PVC, } 10 \text { feet } \\
\text { of } 12 \text { inch schedule } 40 \text { PVC, and } 10 \text { feet of } 4 \text { inch schedule } 80 \text { PVC. }\end{array}$ & $80^{\prime}$ from 2-G7 \\
\hline $2-\mathrm{G} 7$ & $\begin{array}{l}\text { Shredded tires with pipe on ends. The east end is } 40 \text { feet of } 4 \text { inch schedule } 40 \text { PVC, } 10 \text { feet of } 6 \\
\text { inch schedule } 80 \text { PVC, and } 10 \text { feet of } 4 \text { inch schedule } 80 \text { PVC. The west end is } 40 \text { feet of } 4 \text { inch } \\
\text { schedule } 80 \text { PVC, } 10 \text { feet of } 6 \text { inch schedule } 80 \text { PVC, and six sets of alternating } 10 \text { foot lengths of } \\
4 \text { inch schedule } 80 \text { PVC telescoped with } 12 \text { inch schedule } 40 \text { PVC. }\end{array}$ & 80 'from 2-G8 \\
\hline $2-G 8$ & Same as 2-G2 & $80^{\prime}$ from 2-G9 \\
\hline 2-G9 & Same as 2-G2 & 40 'from south toe \\
\hline $3-\mathrm{G} 1$ & $\begin{array}{l}\text { Shredded tires with pipe on west end. No pipe on east end. The west end is } 40 \text { feet of } 4 \text { inch } \\
\text { schedule } 80 \text { PVC, and three sets of alternating } 10 \text { foot lengths of } 6 \text { inch schedule } 80 \text { PVC } \\
\text { telescoped with } 4 \text { inch schedule } 80 \text { PVC. }\end{array}$ & 80' from 3-G2 \\
\hline $3-\mathrm{G} 2$ & Same as 3-G1 & $80^{\prime}$ from $3-\mathrm{G} 3$ \\
\hline 3 -G3 & Same as 3-G1 & 80 ' from 3-G4 \\
\hline $3-\mathrm{G} 4$ & Same as 3-G1 & 80 from 3-G5 \\
\hline 3 -G5 & Same as 3-G1 & 80 ' from 3-G6 \\
\hline 3-G6 & $\begin{array}{l}\text { Shredded tires with pipe on west end. No pipe on east end. The west end is } 50 \text { feet of } 4 \text { inch } \\
\text { schedule } 80 \text { PVC, and } 60 \text { feet of alternating } 10 \text { foot lengths of } 6 \text { inch and } 4 \text { inch schedule } 80 \\
\text { PVC. }\end{array}$ & 80 ' from 3-G7 \\
\hline 3-G7 & Same as 3-G1 & $\begin{array}{l}40 \text { from south } \\
\text { toe }\end{array}$ \\
\hline 4-G1 & $\begin{array}{l}\text { Shredded tires with pipe on ends. The north and south ends are } 3 \text { sets of alternating } 10 \text { foot } \\
\text { lengths of } 6 \text { inch schedule } 80 \text { PVC and } 6 \text { inch schedule } 40 \text { PVC, and one additional10 foot length } \\
\text { of } 6 \text { inch schedule } 80 \text { PVC. }\end{array}$ & $\begin{array}{l}40^{\prime} \text { from south } \\
\text { toe }\end{array}$ \\
\hline 4-G2 & Same as 4-G1 & 50 from 4-G1 \\
\hline
\end{tabular}

${ }^{1}$ Gas Collection Line Nomenclature: Layer \#-G (for gas) and line \#

${ }^{2}$ Polyvinyl chloride, PVC 
Table 5-1. Summary of Data for the Aerobic Cell

\begin{tabular}{|c|c|c|}
\hline Description & \multicolumn{2}{|c|}{ Data } \\
\hline Footprint & \multicolumn{2}{|c|}{2.3 acres } \\
\hline Average Waste Depth & \multicolumn{2}{|c|}{30 feet } \\
\hline Construction of the Base Liner & \multicolumn{2}{|c|}{ August 2001} \\
\hline Waste Filling of Cells & \multicolumn{2}{|c|}{$8 / 8 / 2001-9 / 26 / 2001$} \\
\hline Total \# of Waste Lifts & \multicolumn{2}{|c|}{3} \\
\hline Total Amount of Waste & \multicolumn{2}{|c|}{11,942 tons } \\
\hline Total Amount of Greenwaste ADC ${ }^{1}$ & \multicolumn{2}{|c|}{2,169 tons } \\
\hline $\begin{array}{l}\text { Total \# of Corrugated Metal Pipe Horizontal Air Collection Lines } \\
\text { Layer } 1 \\
\text { Layer } 2\end{array}$ & $\begin{array}{l}6 \\
3 \\
3\end{array}$ & Spacings vary. \\
\hline $\begin{array}{l}\text { Total \# of CPVC }{ }^{2} \text { Pipe Horizontal Air Collection Lines } \\
\text { Layer } 1 \\
\text { Layer } 2\end{array}$ & $\begin{array}{l}5 \\
3 \\
2\end{array}$ & Spacings vary. \\
\hline $\begin{array}{l}\text { Total Amount of Air Collection Lines }{ }^{3} \\
\text { Layer } 1 \\
\text { Layer } 2\end{array}$ & $\begin{array}{l}1,6 \\
1,1 \\
560\end{array}$ & $\begin{array}{l}\text { feet } \\
\text { feet } \\
\text { et }\end{array}$ \\
\hline $\begin{array}{l}\text { Total \# of HDPE }{ }^{4} \text { Pipe Liquid Addition Lines } \\
\text { Layer } 1 \\
\text { Layer } 2 \\
\text { Layer } 3\end{array}$ & $\begin{array}{l}21 \\
10 \\
8 \\
3\end{array}$ & $\begin{array}{l}\text { Spacings approximately } \\
40 \text { feet on center to } \\
\text { alternate with CPVC pipe } \\
\text { for liquid addition lines. }\end{array}$ \\
\hline $\begin{array}{l}\text { Total \# of CPVC Pipe Liquid Addition Lines } \\
\text { Layer } 1 \\
\text { Layer } 2\end{array}$ & & $\begin{array}{l}\text { Spacings of approximately } \\
40 \text { feet on center to alternate } \\
\text { with HDPE pipe } \\
\text { for liquid addition lines. }\end{array}$ \\
\hline $\begin{array}{l}\text { Total Amount of Liquid Addition Piping } \\
\text { Layer } 1 \\
\text { Layer } 2 \\
\text { Layer } 3\end{array}$ & $\begin{array}{l}4,7 \\
2,8 \\
1,4 \\
510\end{array}$ & $\begin{array}{l}\text { feet } \\
\text { feet } \\
\text { feet } \\
\text { et }\end{array}$ \\
\hline $\begin{array}{l}\text { Total \# of } 3 / 32 \text { inch Diameter Holes in Injection Lines } \\
\text { Layer } 1 \\
\text { Layer } 2 \\
\text { Layer } 3\end{array}$ & $\begin{array}{l}326 \\
186 \\
97 \\
43\end{array}$ & \\
\hline
\end{tabular}

${ }^{\mathrm{A}}$ ADC-Alternative Daily Cover

${ }^{2}$ Chlorinated Polyvinyl Chloride, CPVC

${ }^{3}$ Refer to table A for a complete description of air collection lines

${ }^{4}$ High Density Polyethylene, HDPE 
Table 5-2. Summary of Sensors for the Aerobic Cell

\begin{tabular}{|c|c|c|}
\hline $\begin{array}{c}\text { Type of } \\
\text { Instrumentation }\end{array}$ & $\begin{array}{c}\text { FPA Proposed } \\
\text { Location/Quantity/Spacing }\end{array}$ & $\begin{array}{c}\text { Aerobic Cell Actual } \\
\text { Location/Quantity/Spacing }\end{array}$ \\
\hline $\begin{array}{c}\text { Pressure } \\
\text { Transducers }\end{array}$ & $\begin{array}{l}\text { 1. Two over the primary liner at } 200 \\
\text { feet spacing } \\
\text { 2. One within the leachate collection } \\
\text { sump }\end{array}$ & $\begin{array}{l}\text { 1. Two over the primary liner at } 200 \text { feet } \\
\text { spacing } \\
\text { 2. One within the leachate collection sump }\end{array}$ \\
\hline $\begin{array}{l}\text { Bubbler Gage for } \\
\text { Liquid/Gas } \\
\text { Pressure } \\
\text { Measurement and } \\
\text { Liquid/Gas } \\
\text { Sampling }\end{array}$ & $\begin{array}{l}\text { 1. Top of the aerobic bottom liner- } 48 \\
\text { gages at } 50 \text { feet spacing } \\
\text { 2. Top of the first lift of waste- } 24 \\
\text { gages } \\
\text { 3. Top of the second lift of waste- } 20 \\
\text { gages } \\
\text { 4. Top of the final lift of waste- } 20 \\
\text { gages } \\
\text { TOTAL }=112 \text { gages }\end{array}$ & $\begin{array}{l}\text { 1. Top of the aerobic bottom liner- } 12 \\
\text { gages at } 75 \text { feet spacing } \\
\text { 2. Top of the first lift of waste- } 26 \text { gages } \\
\text { 3. Top of the second lift of waste- } 16 \\
\text { gages } \\
\text { 4. Top of the final lift of waste- no gages }\end{array}$ \\
\hline $\begin{array}{l}\text { Moisture and } \\
\text { Temperature } \\
\text { Sensors }\end{array}$ & $\begin{array}{l}\text { 1. Top of the aerobic bottom liner- } 48 \\
\text { temperature and } 12 \text { moisture } \\
\text { sensors } \\
\text { 2. Between bottom liner and the top of } \\
\text { the first lift of waste- no sensors } \\
\text { 3. Top of the first lift of waste- } 24 \\
\text { temperature and moisture sensors } \\
\text { 4. Top of the second lift of waste-20 } \\
\text { temperature and moisture sensors } \\
\text { 5. Top of the final lift of waste-20 } \\
\text { temperature and moisture sensors }\end{array}$ & $\begin{array}{l}\text { 1. Top of the aerobic bottom liner- } 12 \\
\text { temperature and } 2 \text { moisture sensors at } \\
75 \text { feet spacing } \\
\text { 2. Between bottom liner and the top of the } \\
\text { first lift of waste- } 3 \text { temperature sensors } \\
\text { and } 3 \text { moisture sensors at various } \\
\text { spacings. } \\
\text { 3. Top of the first lift of waste- } 26 \\
\text { temperature and } 26 \text { moisture sensors at } \\
\text { various spacings } \\
\text { 4. Top of the second lift of waste- } 18 \\
\text { temperature and } 21 \text { moisture sensors at } \\
\text { various spacings } \\
\text { 5. Top of the final lift of waste-no } \\
\text { temperature or moisture sensors }\end{array}$ \\
\hline & $\begin{array}{l}\text { TOTAL }=112 \text { temperature sensors } \\
\text { and } 76 \text { moisture sensors }\end{array}$ & $\begin{array}{l}\text { TOTAL }=59 \text { temperature sensors and } \\
52 \text { moisture sensors }\end{array}$ \\
\hline
\end{tabular}


Table 5-3. Summary of Air Collection Lines for the Aerobic Cell

\begin{tabular}{|c|c|c|}
\hline Air Collection Line & Description & Spacing \\
\hline $1-\mathrm{A} 1$ & $\begin{array}{l}\text { Alternating } 10 \text { foot lengths of } 4 \text { and } 6 \text { inch schedule } 80 \\
\text { CPVC }^{2} \text {. }\end{array}$ & 30' from west toe \\
\hline $1-\mathrm{A} 2$ & $\begin{array}{l}\text { Alternating } 10 \text { foot lengths of } 6 \text { and } 8 \text { inch corrugated } \\
\text { metal pipe. }\end{array}$ & $40^{\prime}$ from $1-\mathrm{A} 1-\mathrm{SE}$ \\
\hline $1-\mathrm{A} 3$ & $\begin{array}{l}\text { Alternating } 10 \text { foot lengths of } 6 \text { and } 8 \text { inch corrugated } \\
\text { metal pipe. }\end{array}$ & 40’ from 1-A2-SE \\
\hline $1-\mathrm{A} 4$ & $\begin{array}{l}\text { Alternating } 10 \text { foot lengths of } 4 \text { and } 6 \text { inch schedule } 80 \\
\text { CPVC. }\end{array}$ & 40’ from $1-\mathrm{A} 3-\mathrm{SE}$ \\
\hline $1-\mathrm{A} 5$ & $\begin{array}{l}\text { Alternating } 10 \text { foot lengths of } 6 \text { and } 8 \text { inch corrugated } \\
\text { metal pipe. }\end{array}$ & 40' from 1-A4-SE \\
\hline $1-\mathrm{A} 6$ & $\begin{array}{l}\text { Alternating } 10 \text { foot lengths of } 4 \text { and } 6 \text { inch schedule } 80 \\
\text { CPVC. }\end{array}$ & 40 from $1-\mathrm{A} 5-\mathrm{SE}$ \\
\hline $2-\mathrm{A} 1$ & $\begin{array}{l}\text { Alternating } 10 \text { foot lengths of } 6 \text { and } 8 \text { inch corrugated } \\
\text { metal pipe. }\end{array}$ & $25^{\prime}$ from west toe \\
\hline $2-\mathrm{A} 2$ & $\begin{array}{l}\text { Alternating } 10 \text { foot lengths of } 4 \text { and } 6 \text { inch schedule } 80 \\
\text { CPVC. }\end{array}$ & 40' from 2-A1-SE \\
\hline $2-\mathrm{A} 3$ & $\begin{array}{l}\text { Alternating } 10 \text { foot lengths of } 6 \text { and } 8 \text { inch corrugated } \\
\text { metal pipe. }\end{array}$ & 40' from 2-A2-SE \\
\hline $2-\mathrm{A} 4$ & $\begin{array}{l}\text { Alternating } 10 \text { foot lengths of } 4 \text { and } 6 \text { inch schedule } 80 \\
\text { CPVC. }\end{array}$ & 40' from 2-A3-SE \\
\hline $2-\mathrm{A} 5$ & $\begin{array}{l}\text { Alternating } 10 \text { foot lengths of } 6 \text { and } 8 \text { inch corrugated } \\
\text { metal pipe. }\end{array}$ & 40' from 2-A4-SE \\
\hline
\end{tabular}

${ }^{1}$ Air Collection Line Nomenclature: Layer \# - A (for air) and air collection line \#

${ }^{2}$ Chlorinated Polyvinyl Chloride, PVC

Table 6-1. Summary of Sensors for the Module 6D Base Liner

\begin{tabular}{|c|c|c|}
\hline $\begin{array}{c}\text { Type of } \\
\text { Instrumentation }\end{array}$ & $\begin{array}{c}\text { FPA Proposed } \\
\text { Location/Quantity/Spacing }\end{array}$ & $\begin{array}{l}\text { Module 6D Base Liner Actual } \\
\text { Location/Quantity/Spacing }\end{array}$ \\
\hline $\begin{array}{c}\text { Pressure } \\
\text { Transducer }\end{array}$ & $\begin{array}{l}\text { 1. Eight over the primary liner near } \\
\text { the LCRS trench at } 200 \text { feet } \\
\text { spacing } \\
\text { 2. Two over the primary liner within } \\
\text { the leachate collection sumps }\end{array}$ & $\begin{array}{l}\text { 1. Six over the primary liner at } 200 \text { feet } \\
\text { spacing (three near the west LCRS } \\
\text { and three near the east LCRS) } \\
\text { 2. Four over the primary liner within the } \\
\text { leachate collection sumps }\end{array}$ \\
\hline $\begin{array}{l}\text { Bubbler Gage for } \\
\text { Liquid/Gas } \\
\text { Pressure } \\
\text { Measurement and } \\
\text { Liquid/Gas } \\
\text { Sampling }\end{array}$ & $\begin{array}{l}\text { Top of primary bottom liner- } 66 \\
\text { gages at } 75 \text { feet spacing }\end{array}$ & $\begin{array}{l}\text { Top of primary bottom liner- } 66 \text { gages } \\
\text { at } 75 \text { feet spacing }\end{array}$ \\
\hline $\begin{array}{c}\text { Moisture and } \\
\text { Temperature } \\
\text { Sensors }\end{array}$ & $\begin{array}{l}\text { Top of primary bottom liner- } 66 \\
\text { temperature sensors at } 75 \text { feet } \\
\text { spacing and } 12 \text { moisture sensors }\end{array}$ & $\begin{array}{l}\text { Top of primary bottom liner- } 66 \\
\text { temperature sensors at } 75 \text { feet spacing } \\
\text { and } 12 \text { moisture sensors }\end{array}$ \\
\hline
\end{tabular}


APPENDIX B - PIPING AND INSTRUMENTATION PLAN 


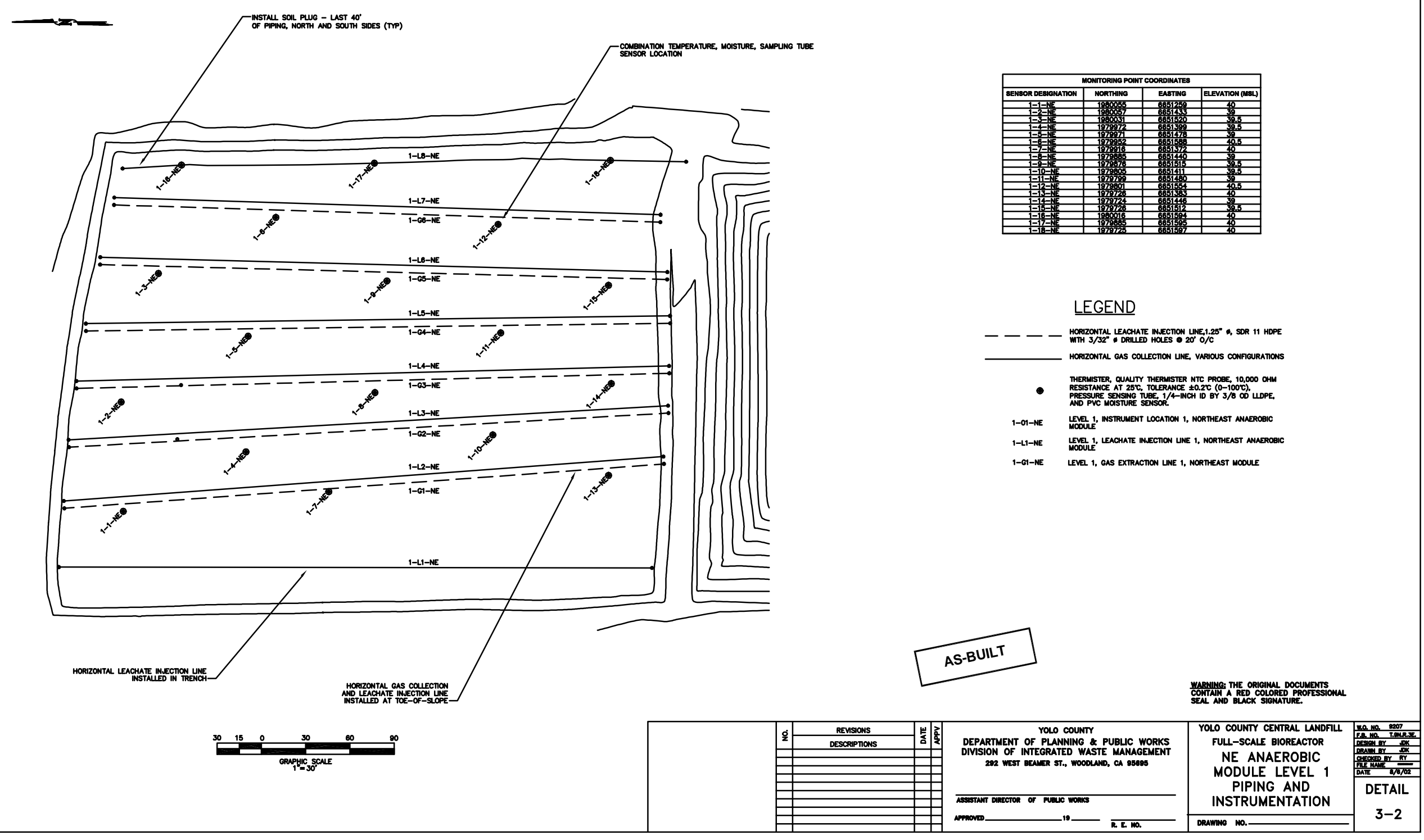




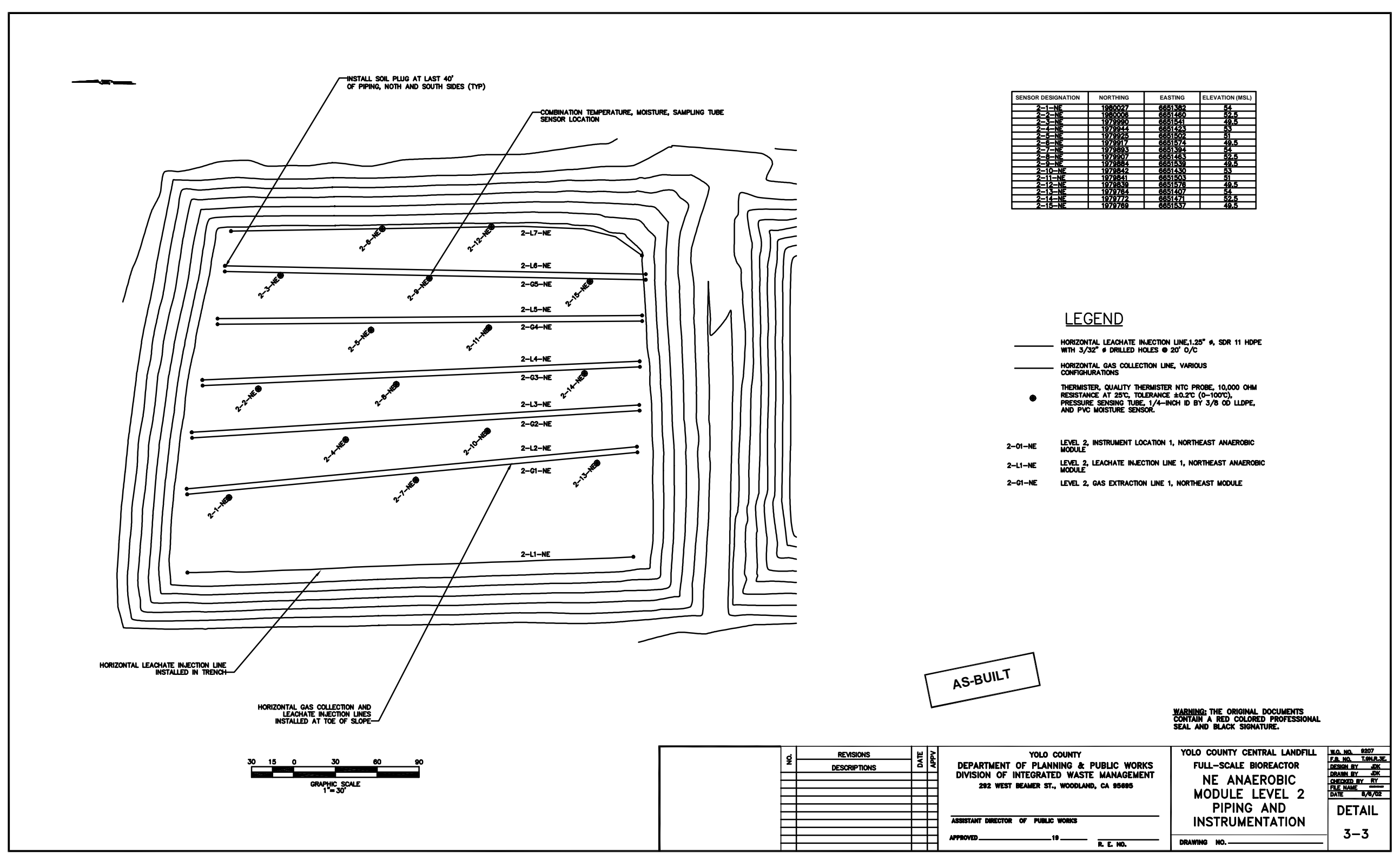



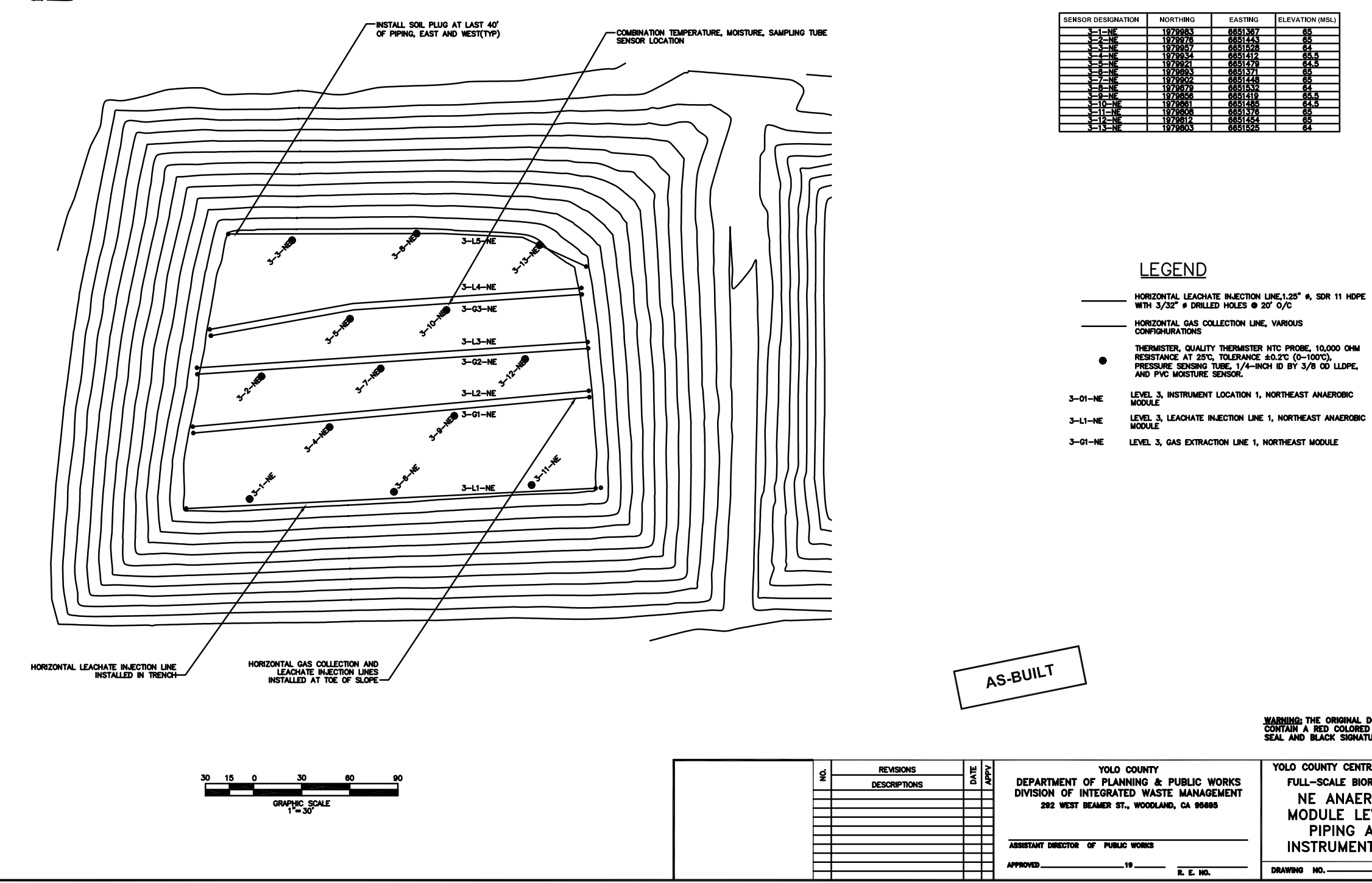

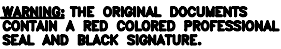

YOLO COUNTY CENTRAL UNOFILI FULL-SCALE BIOREACTOR

PIPING AND

INSTRUMENTATION

oummo no. 


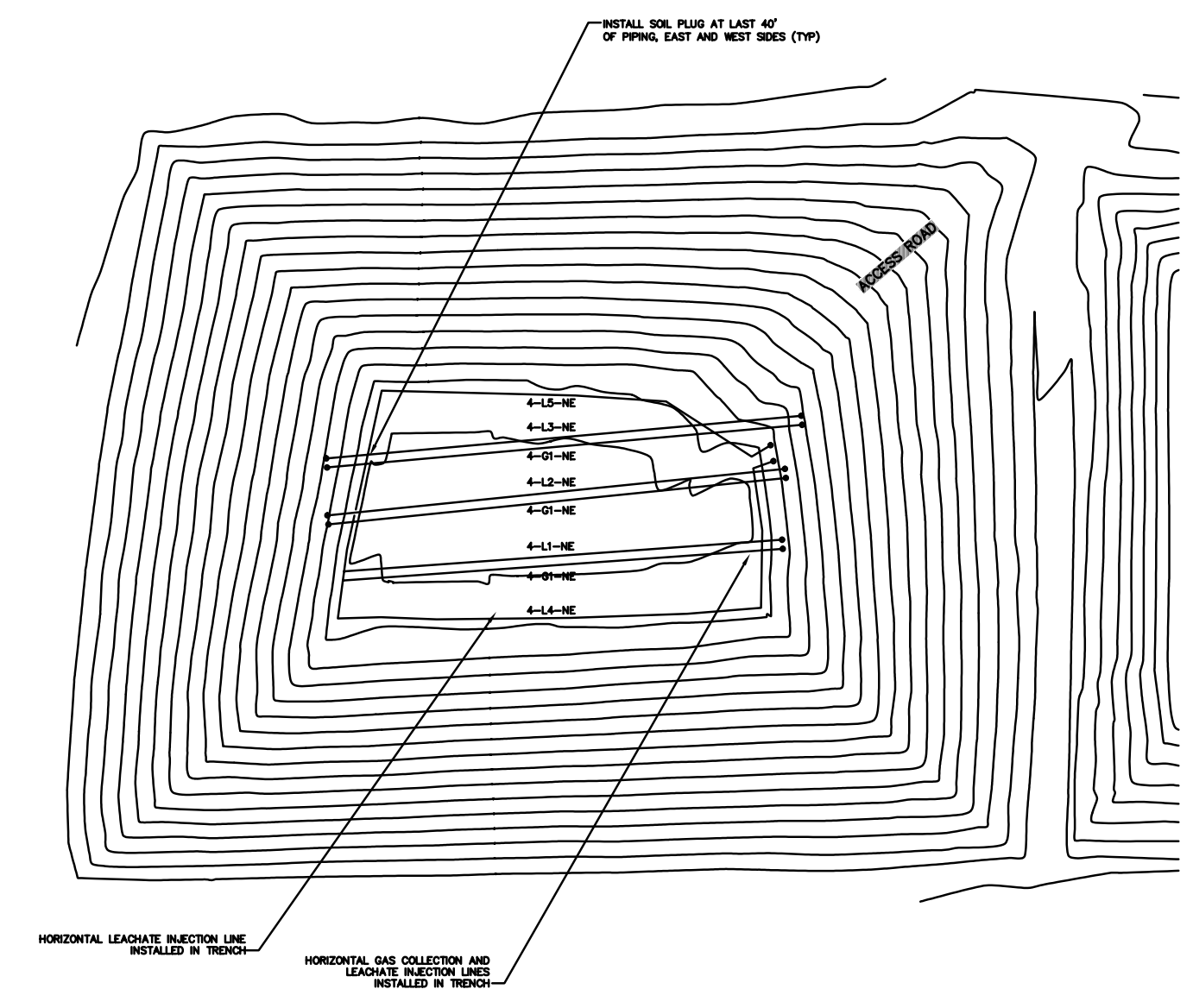

LEGEND

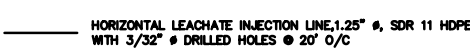

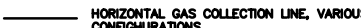

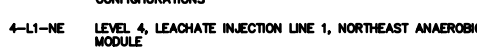

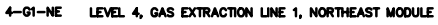

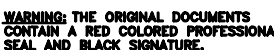
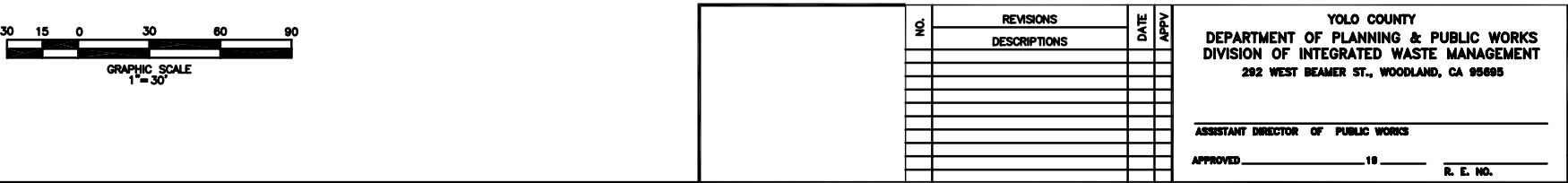

YOO COUNTY CENTRAL LANDO FULL-SCALE BIOREACTOR NE ANAEROBIC MODULE LEVEL INSTRUMENTATION INSTRUM 


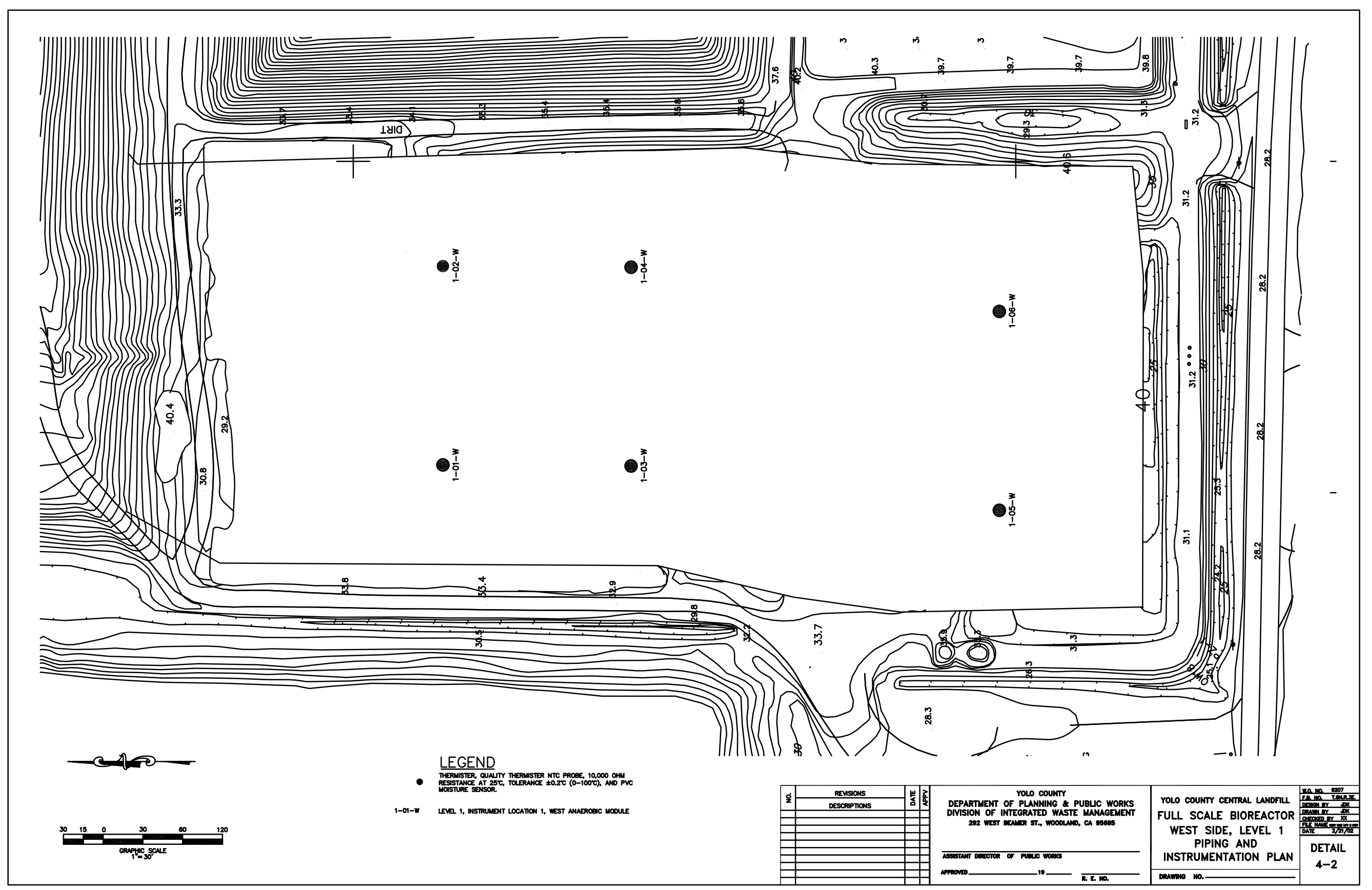




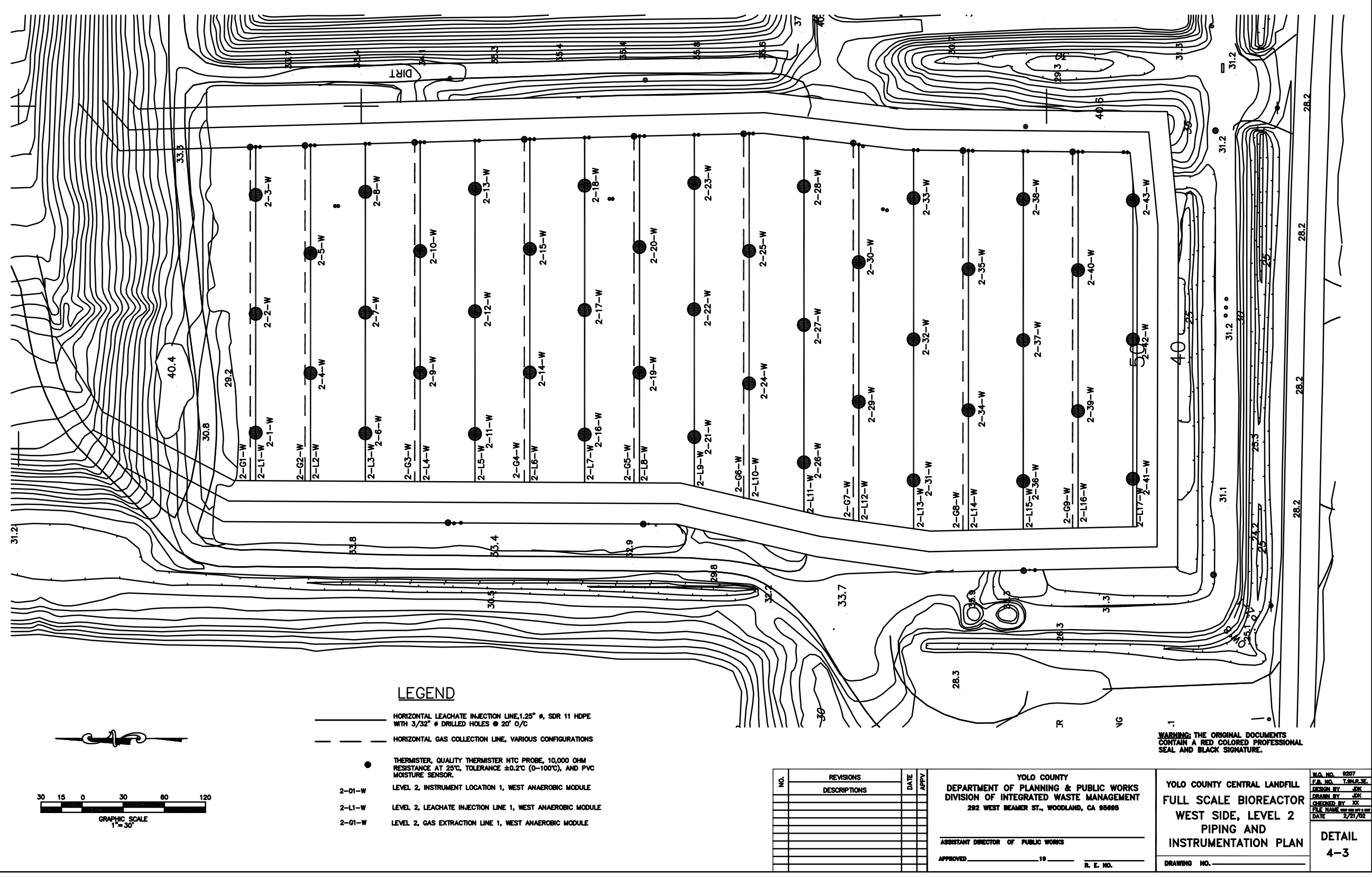




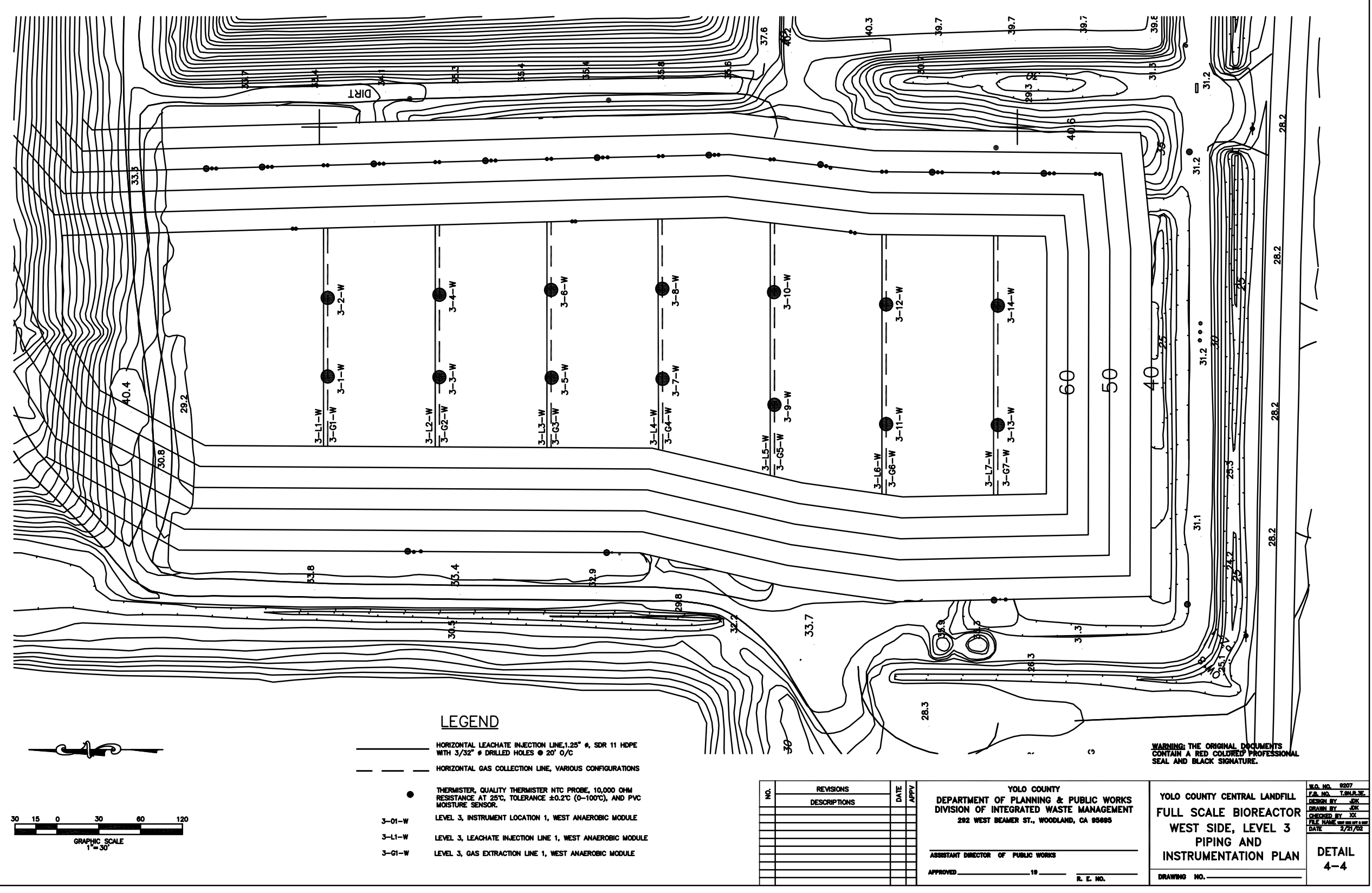




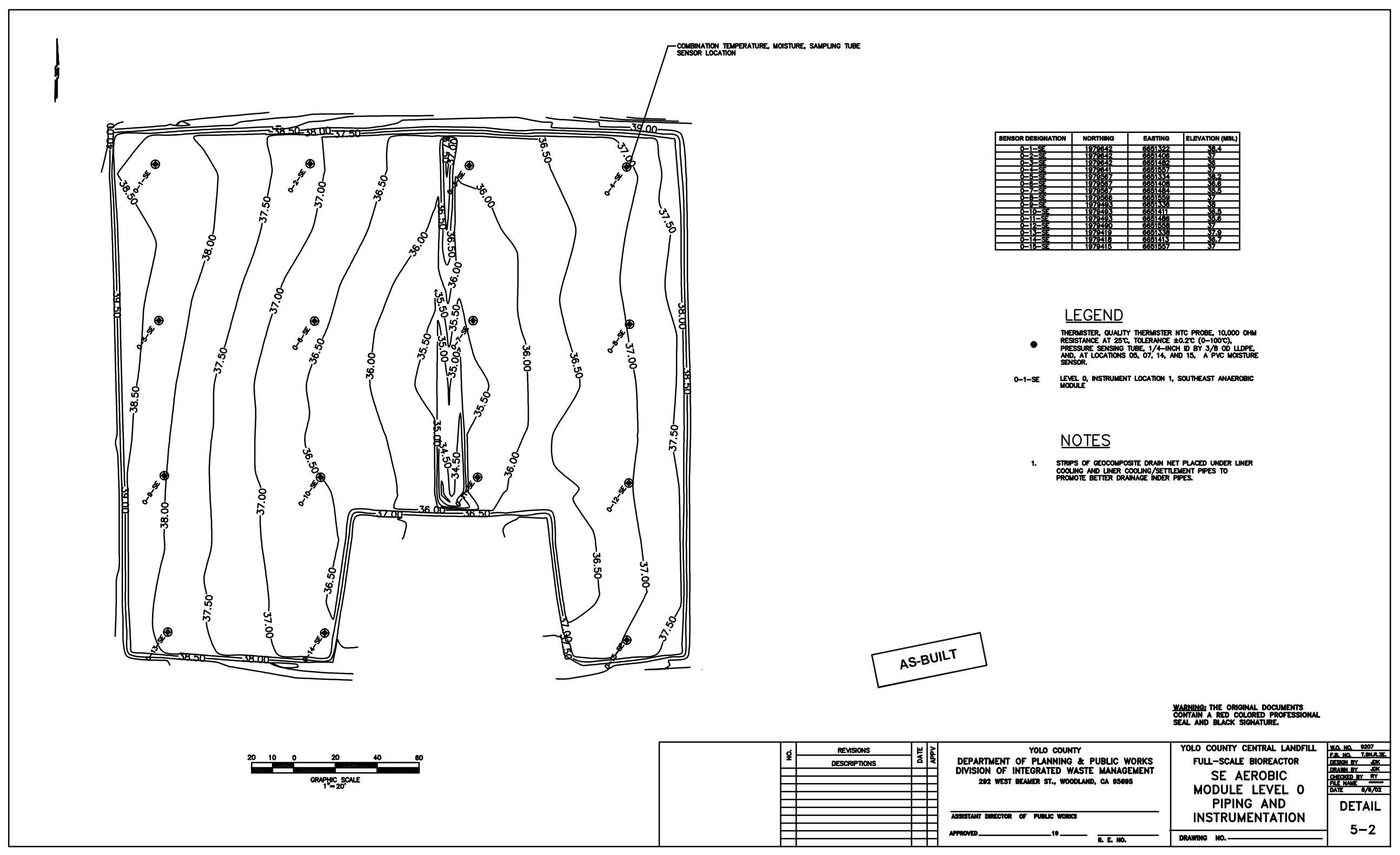




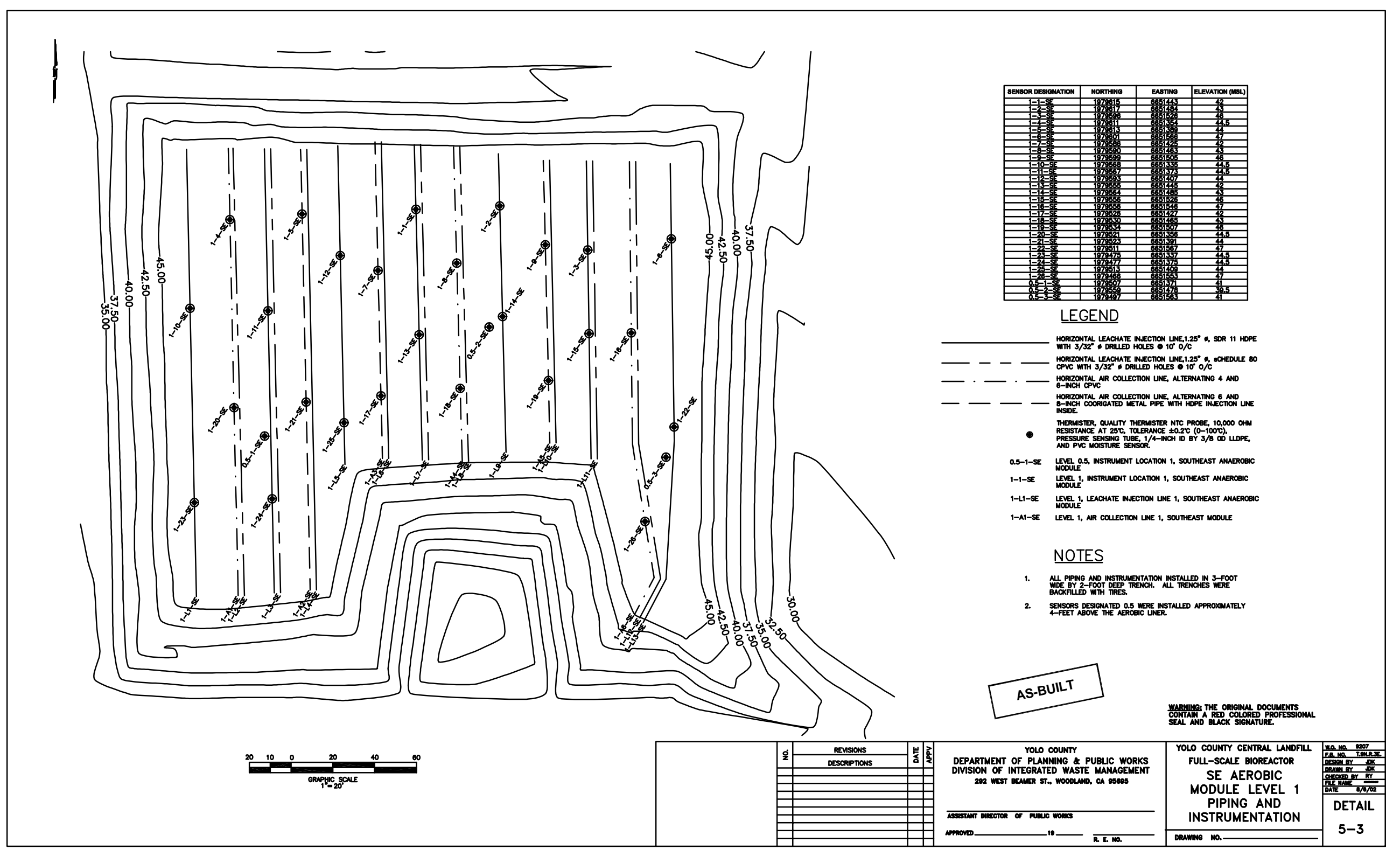




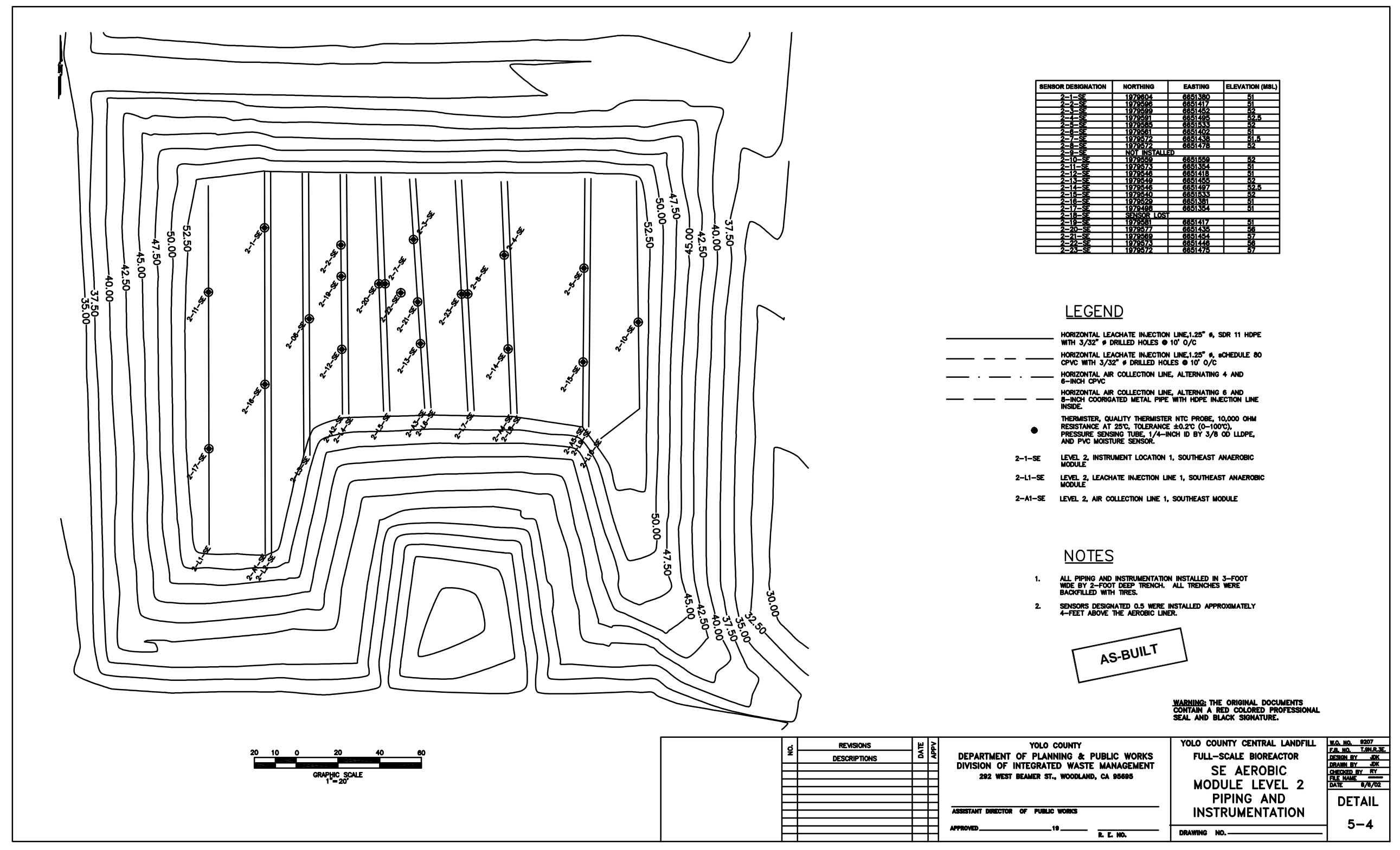




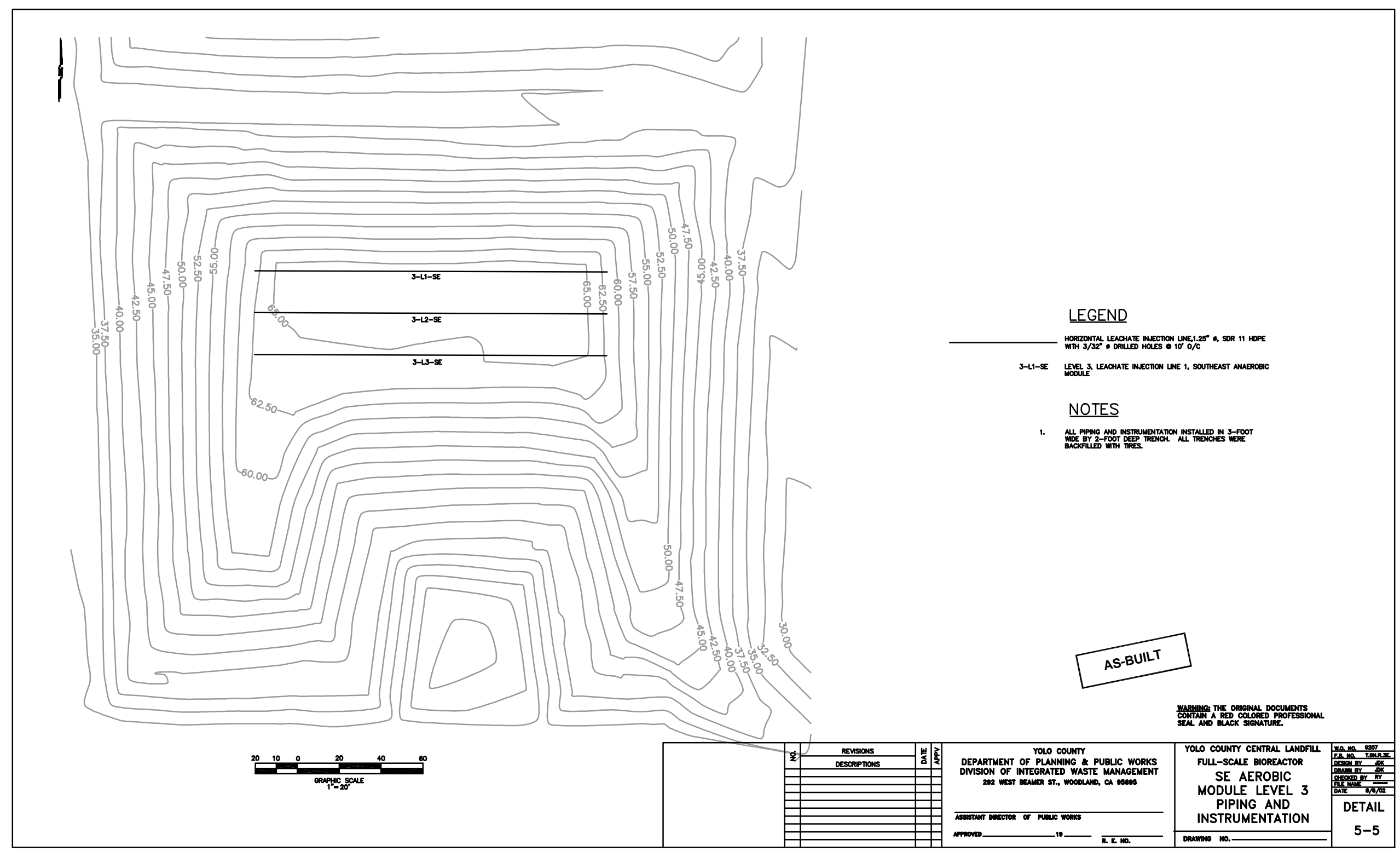




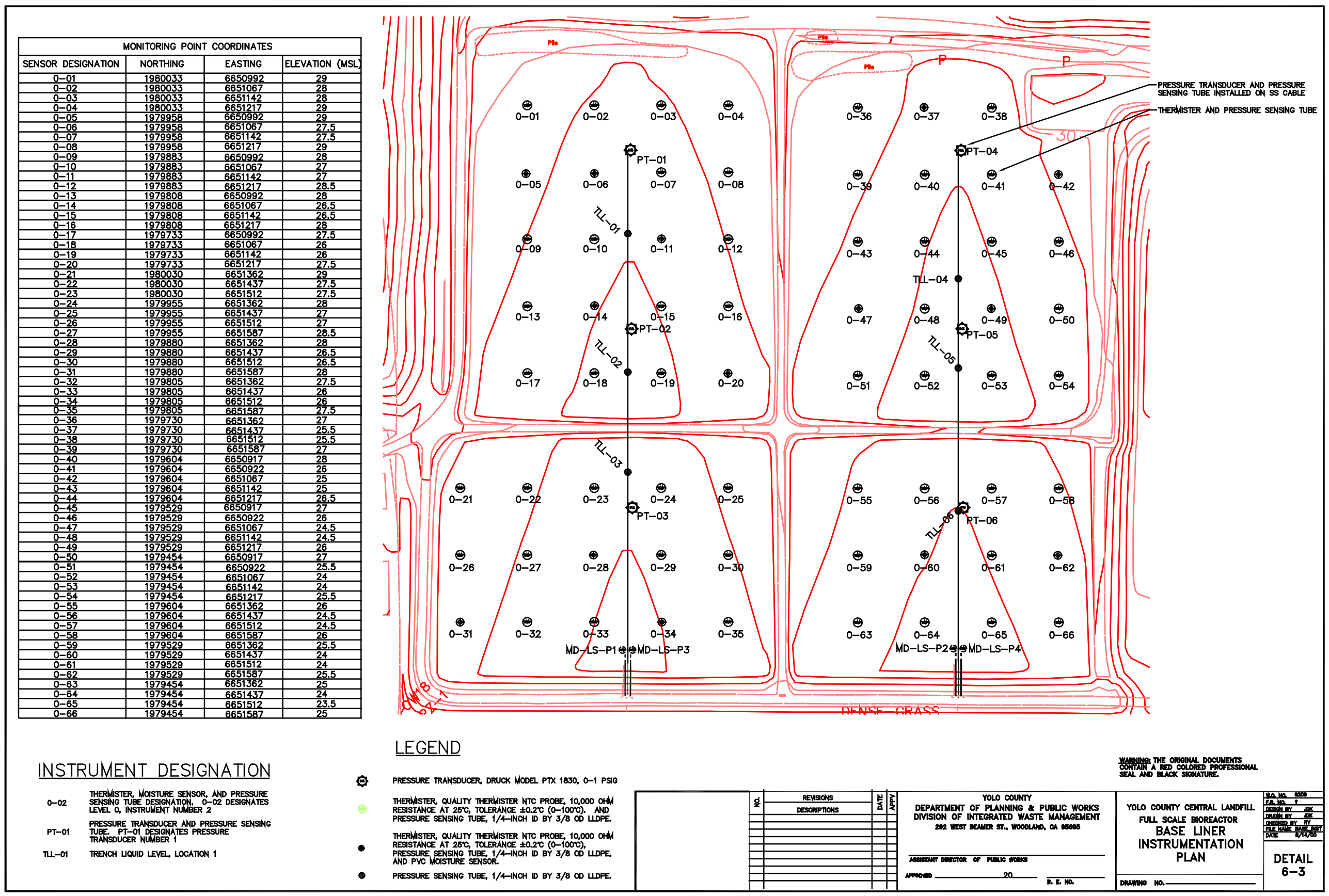


APPENDIX C - GRAPHS 
Figure 3-1. Northeast Anaerobic Cell Liquid Recirculation and Addition Volumes

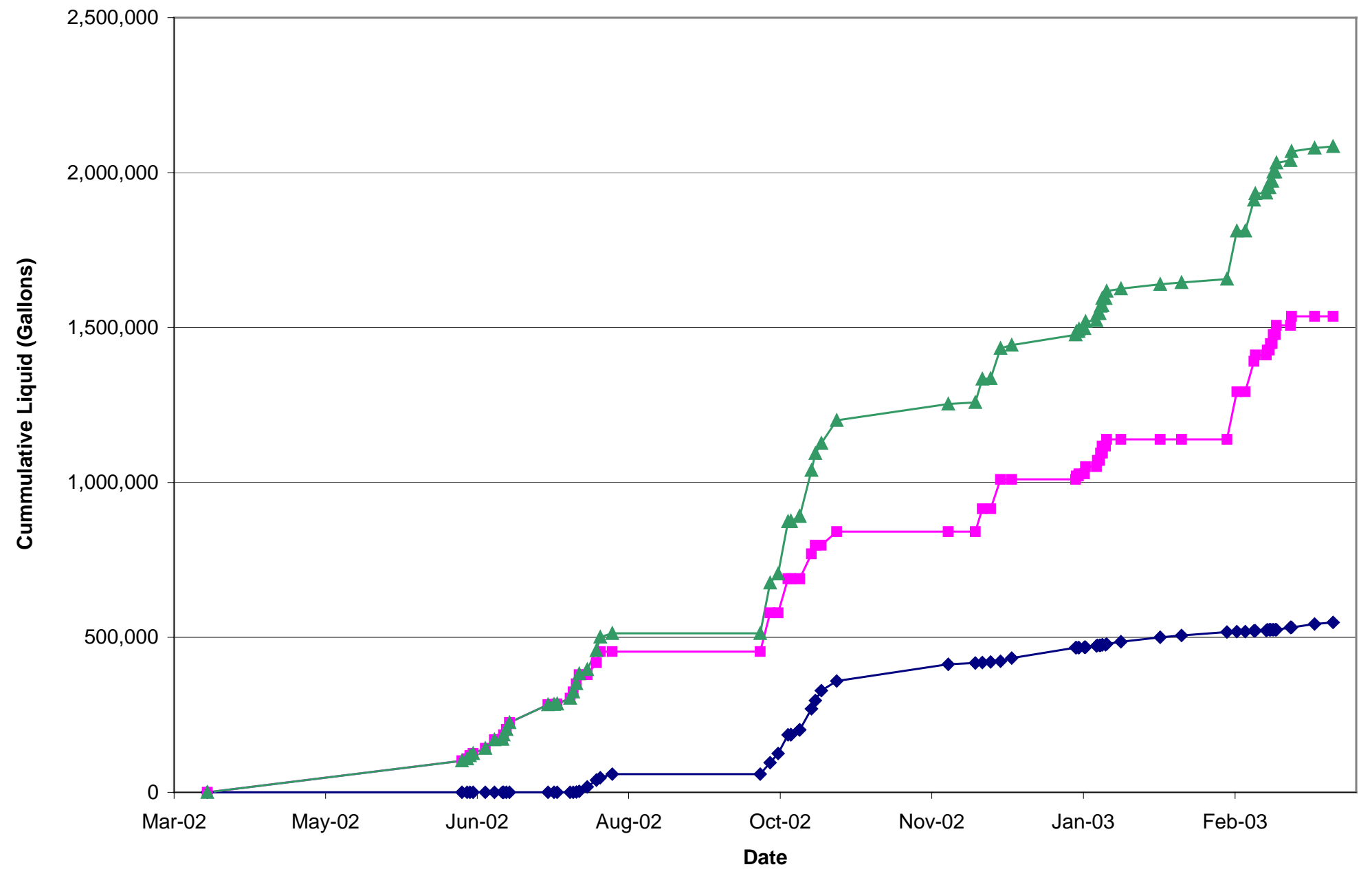

$\neg$ Leachate Recirculated $\rightarrow$ Supplemental Liquid Added $\rightarrow$ Total Liquid Added: Supplemetal Liquid plus Recirculated Leachate Between September 24, 2002 and October 4, 2002 35,460 gallons of liquid was removed from the sump during injection line cleaning. 
Figure 3-2. Northeast Anaerobic Cell Layer 1 Temperature Readings

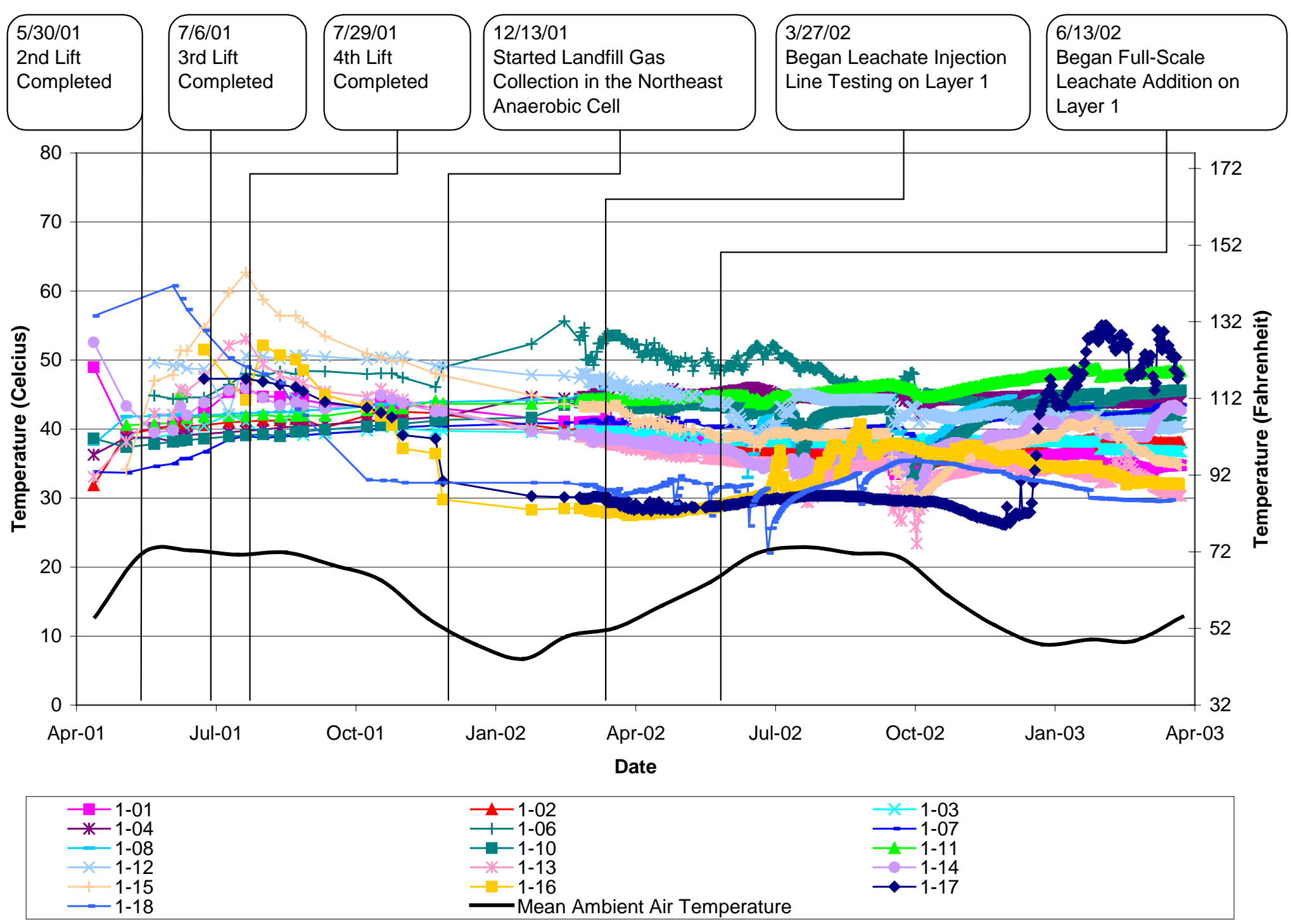


Figure 3-3. Northeast Anaerobic Cell Layer 2 Temperature Readings

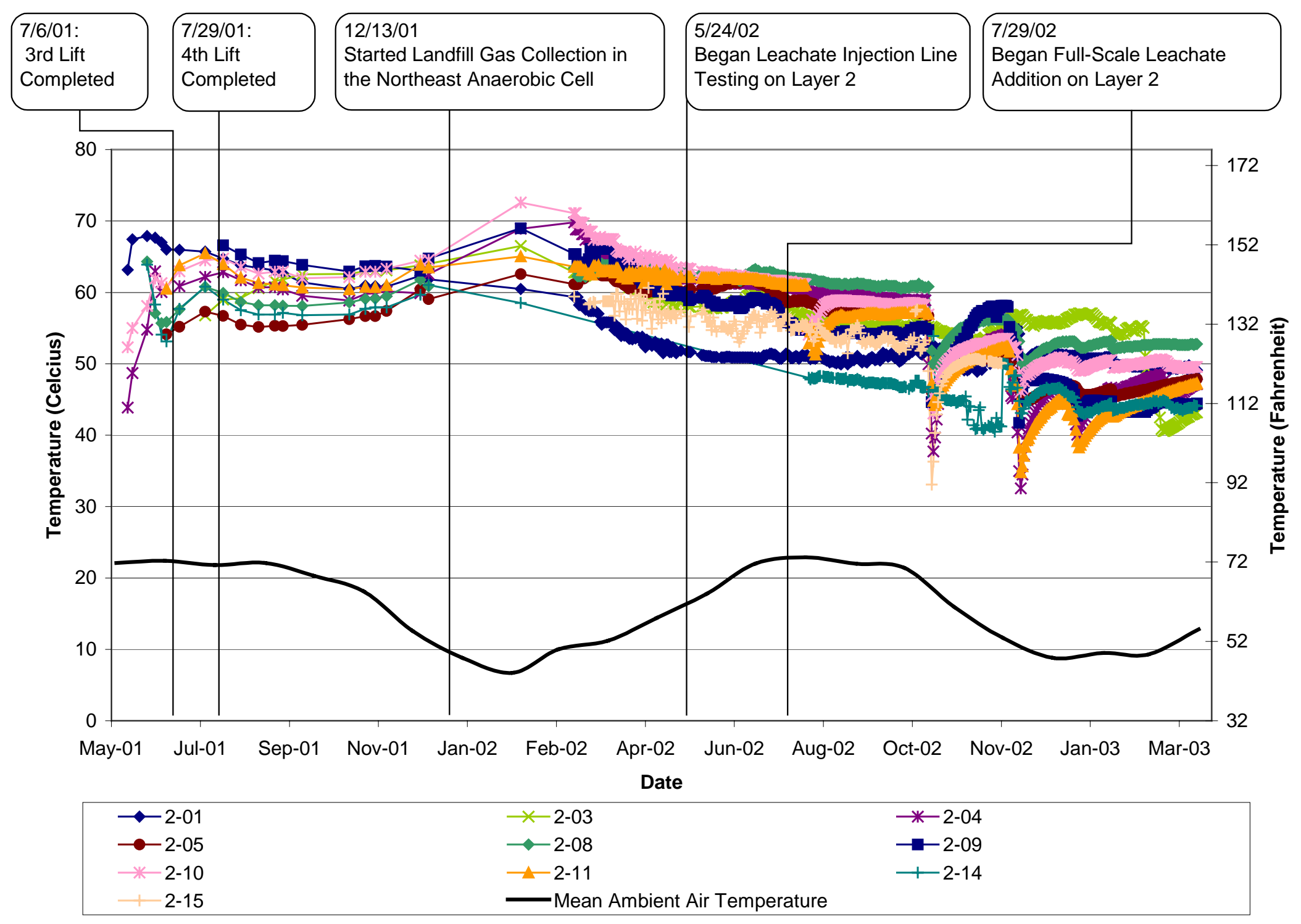


Figure 3-4. Northeast Anaerobic Cell Layer 3 Temperature Readings

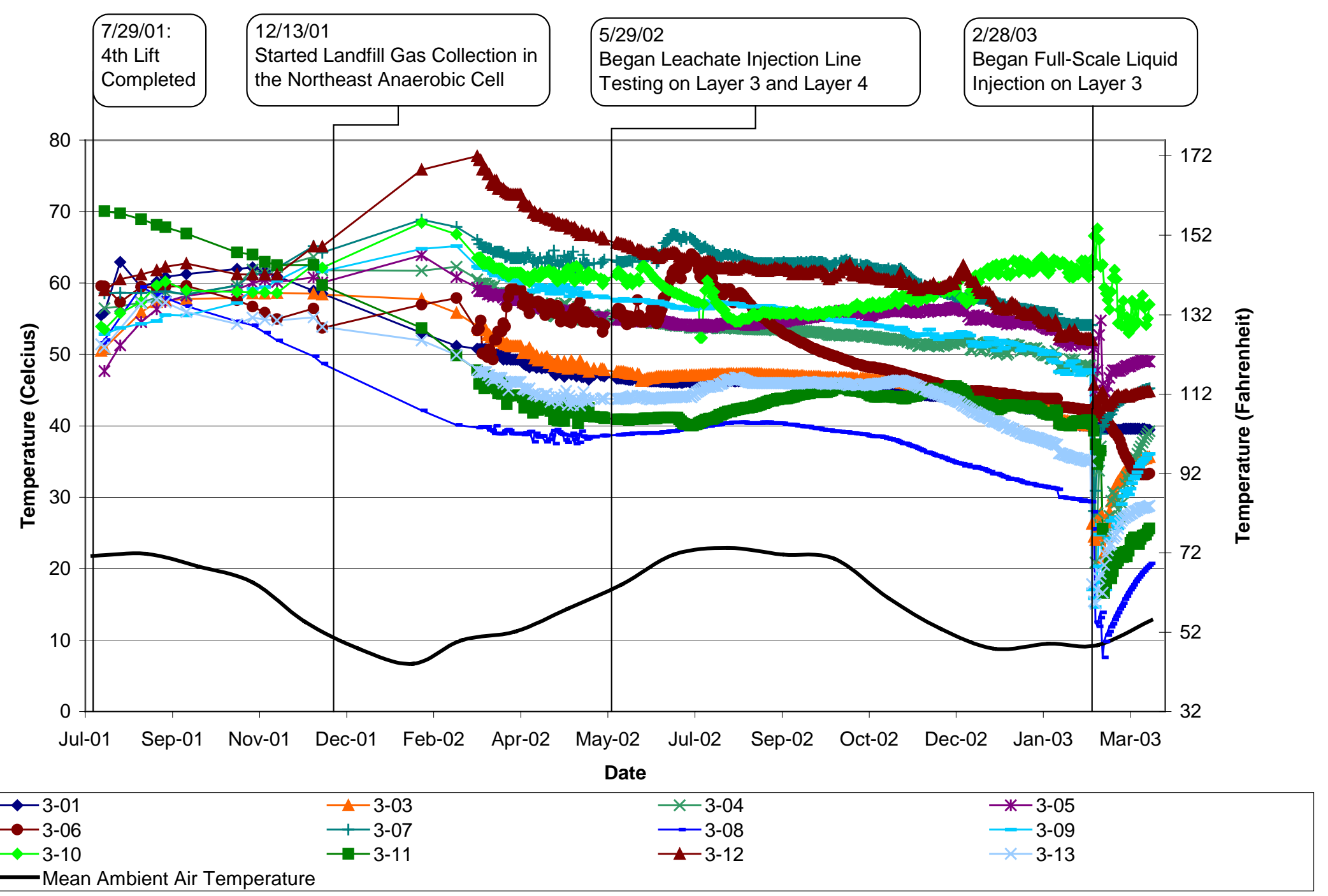


Figure 3-5. Northeast Anaerobic Cell Selected Temperature Readings

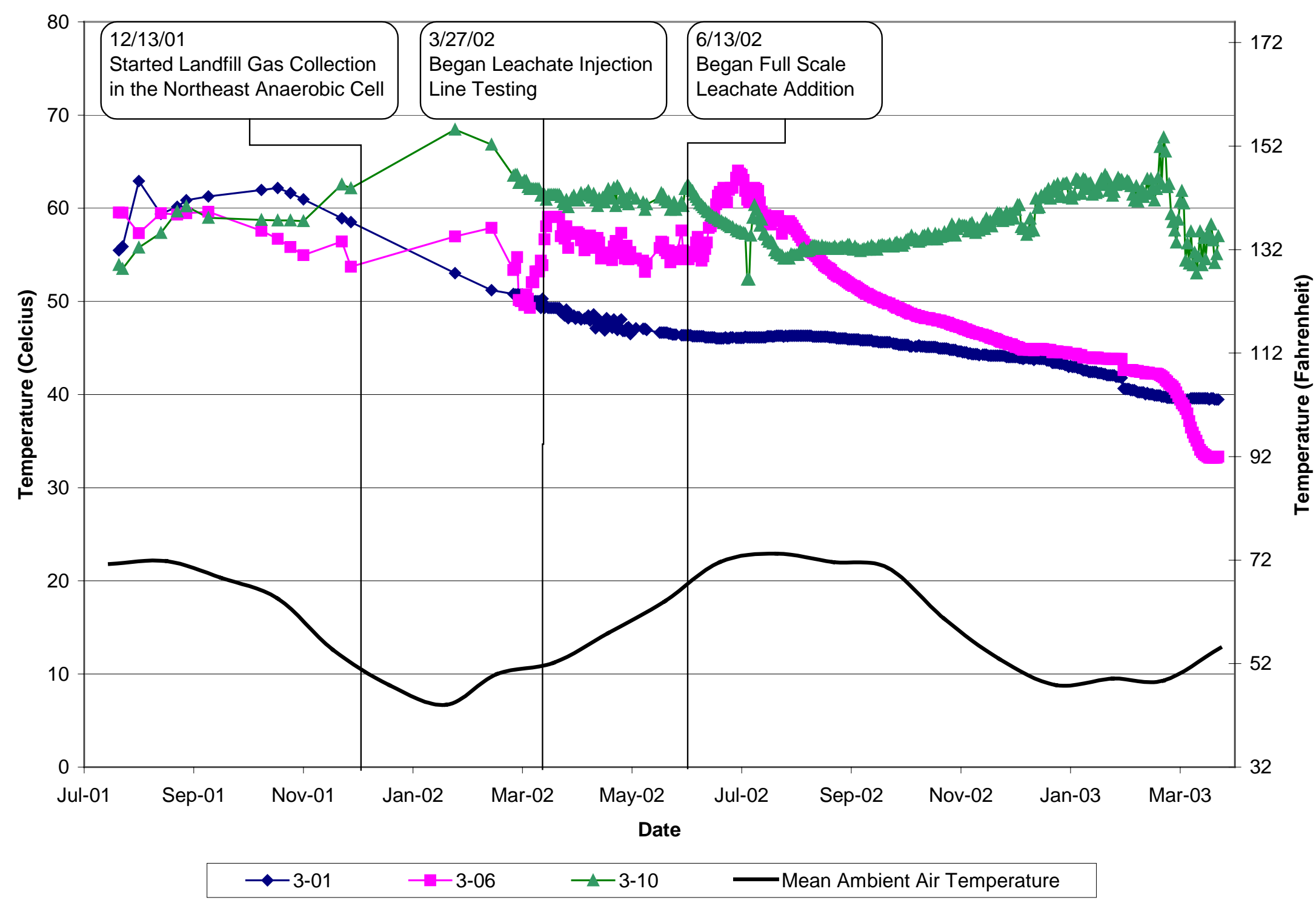


Figure 3-7. Northeast Anaerobic Cell Layer 1 PVC Moisture Readings

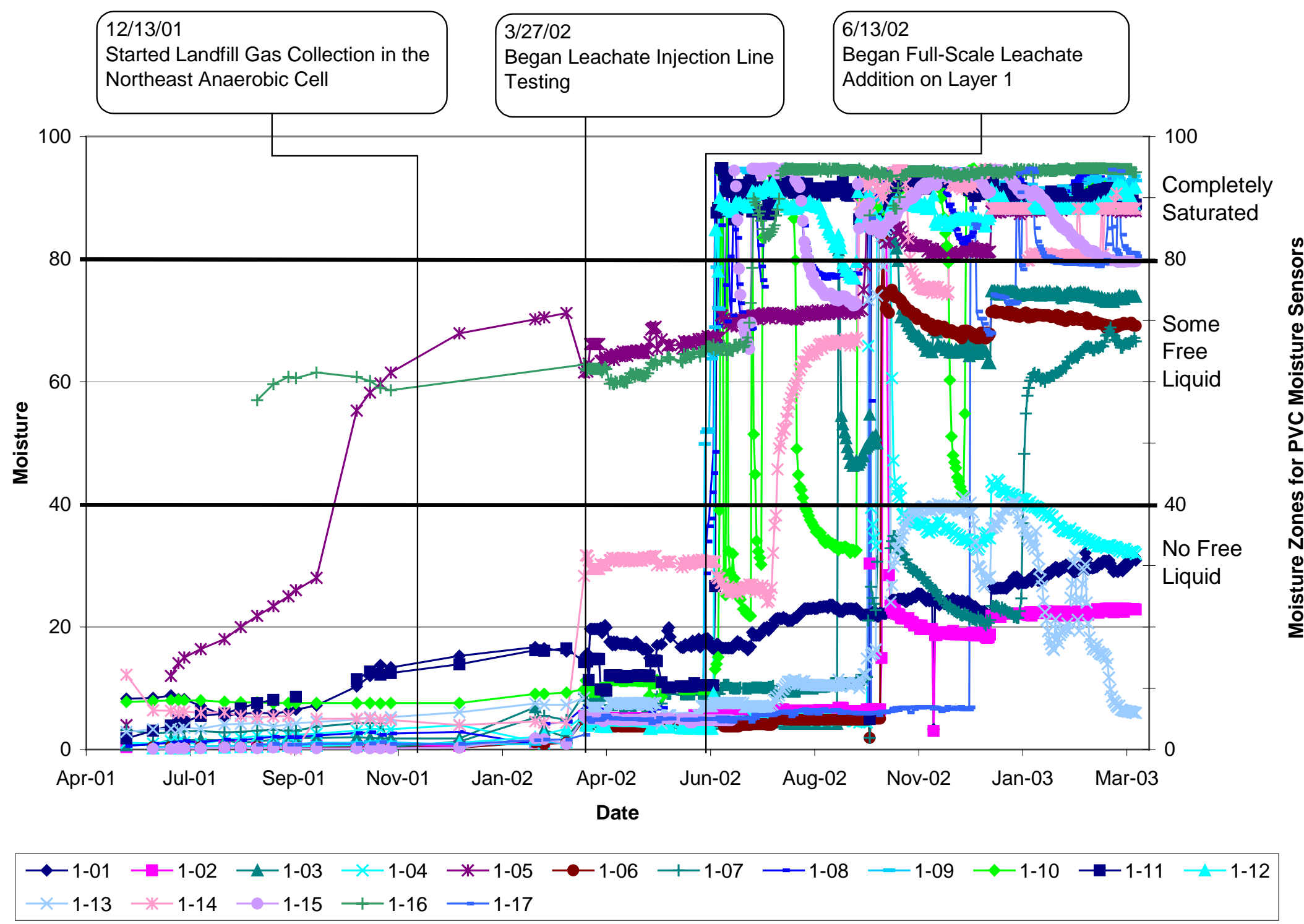

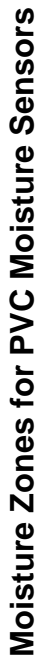


Figure 3-8. Northeast Anaerobic Cell Layer 2 PVC Moisture Readings

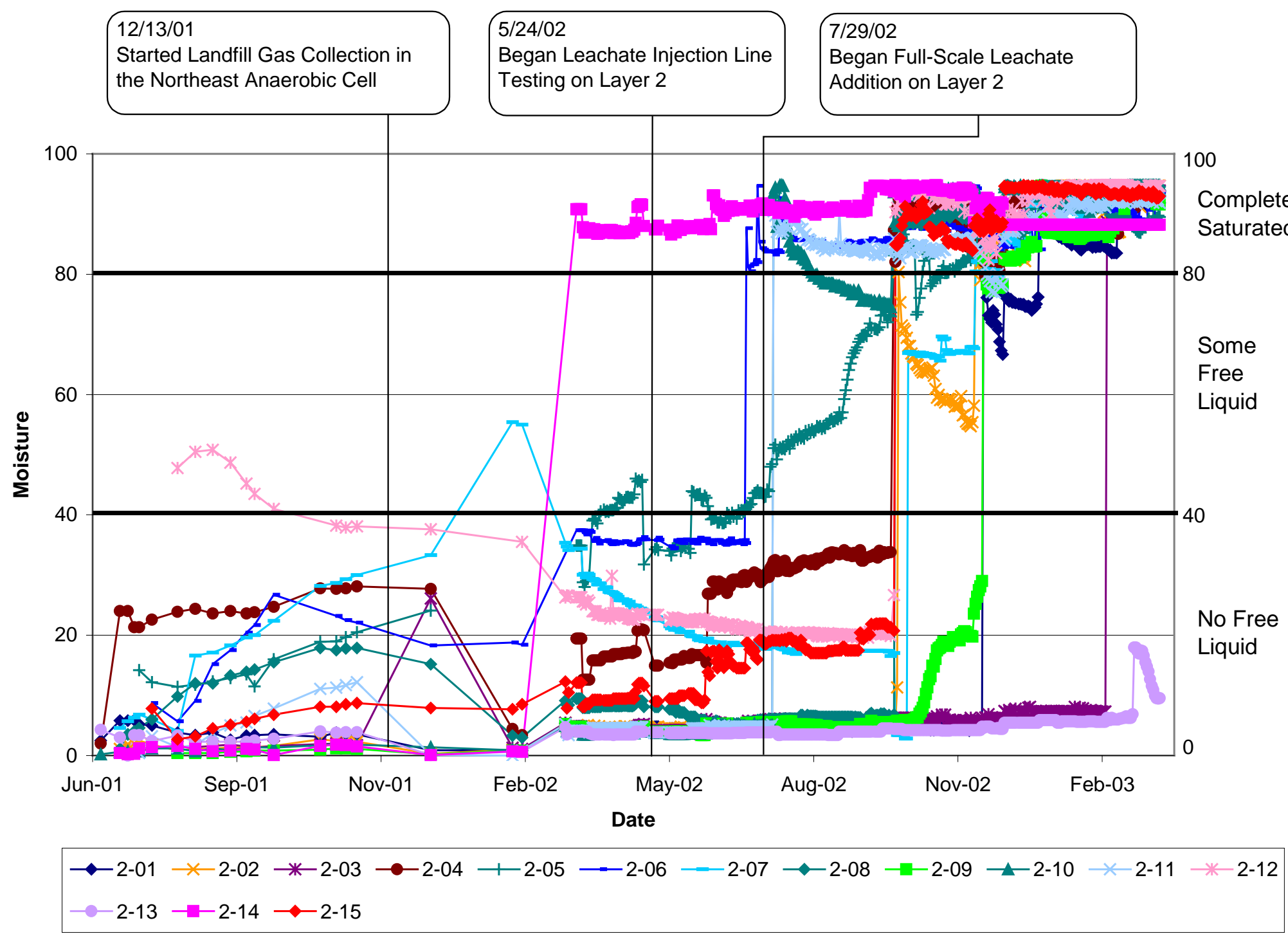

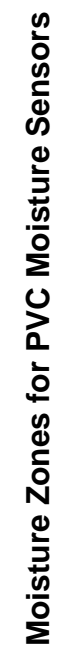


Figure 3-9. Northeast Anaerobic Cell Layer 2 Gypsum in Plaster Moisture Readings

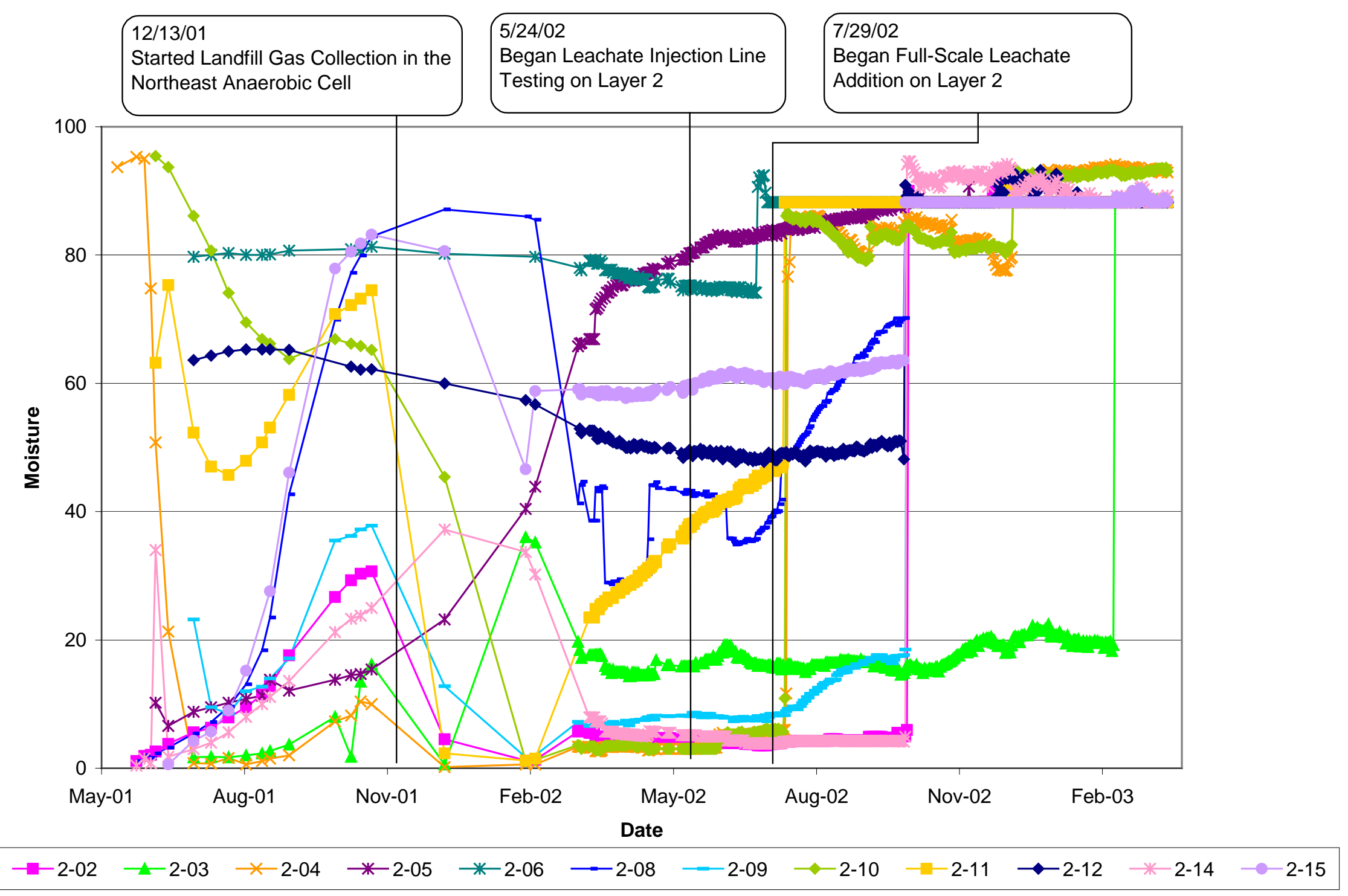


Figure 3-10. Northeast Anaerobic Cell Layer 2 Gypsum in Soil Moisture Readings

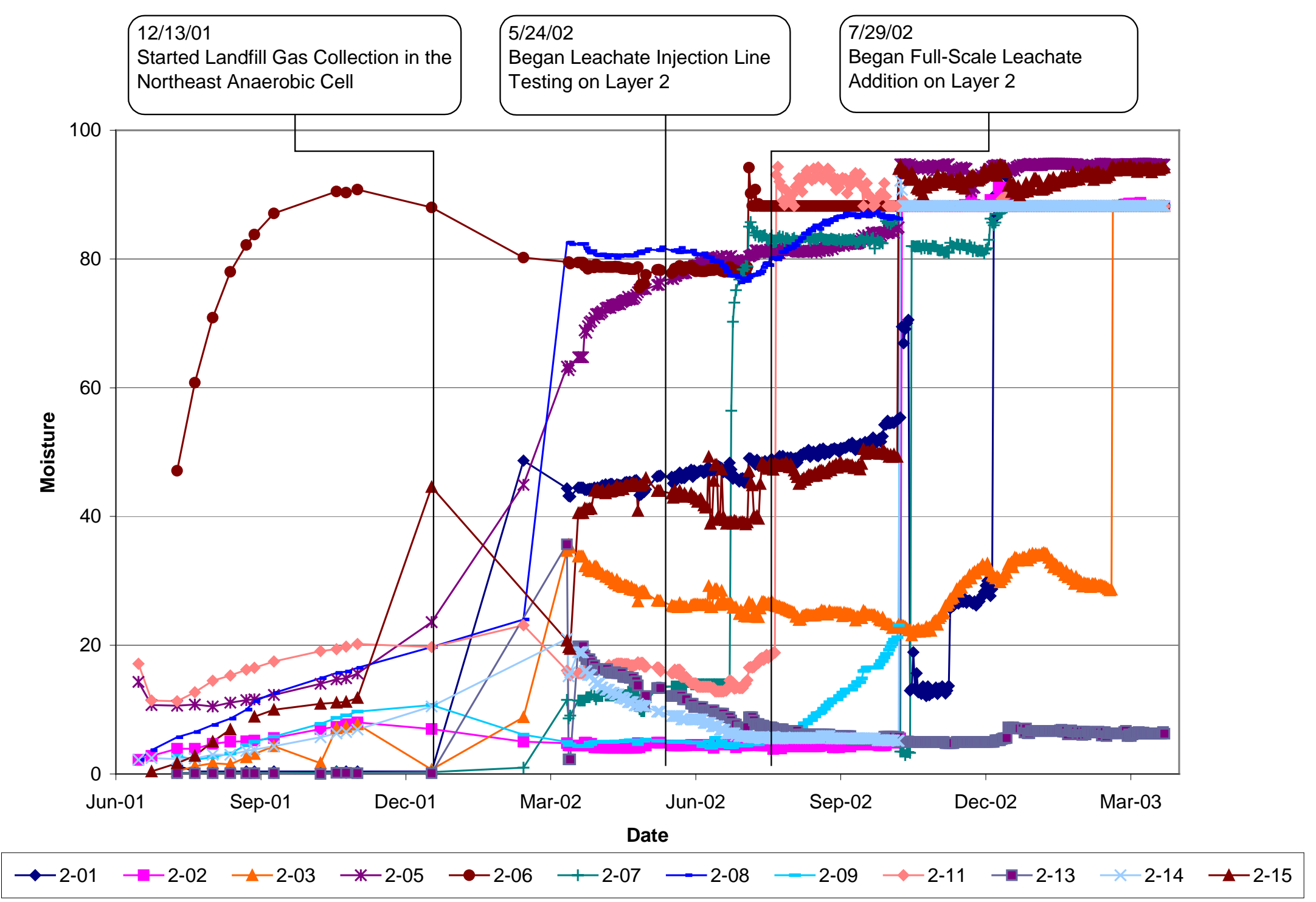


Figure 3-11. Northeast Anaerobic Cell Layer 3 PVC Moisture Readings

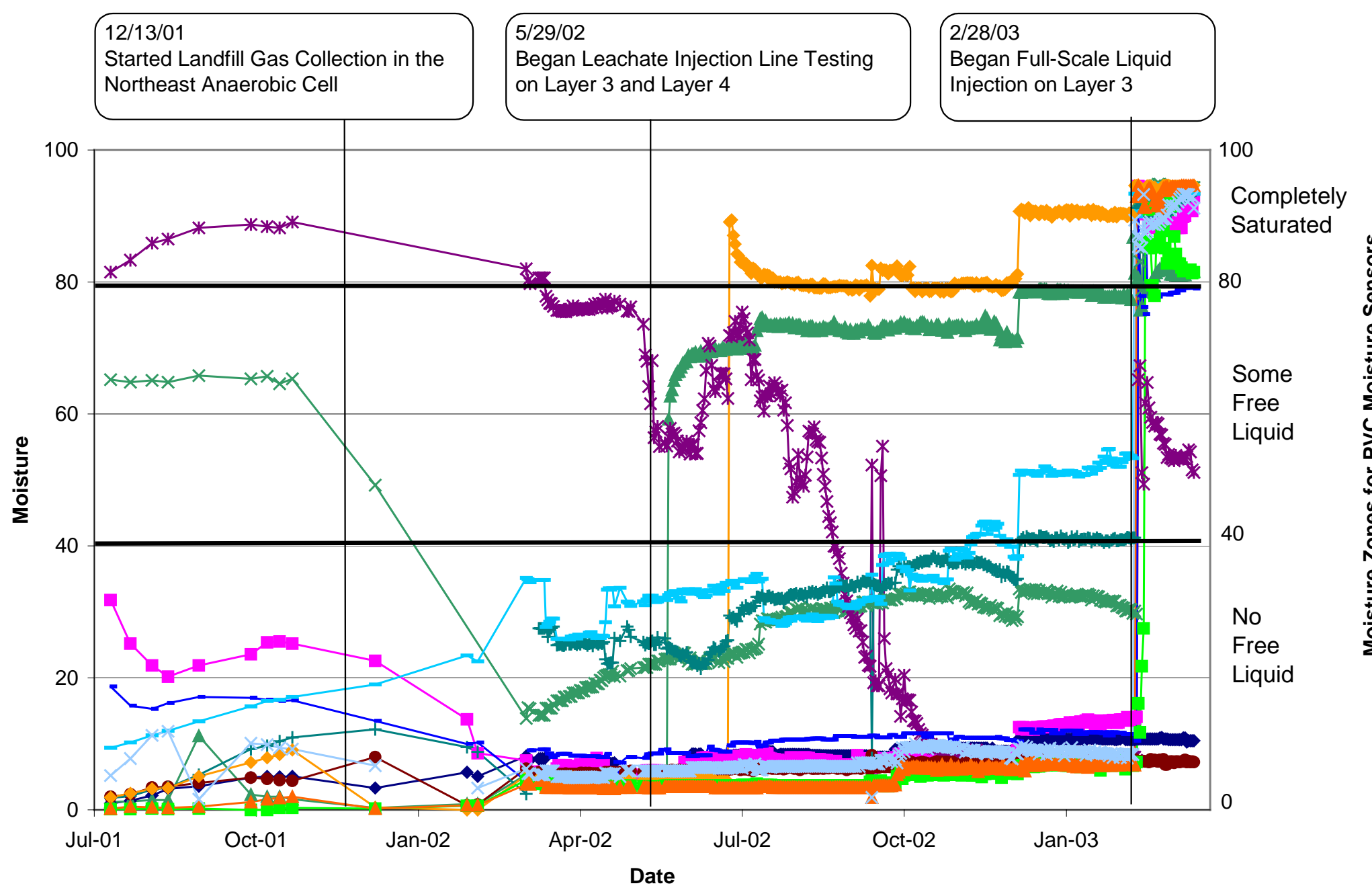


Figure 3-13. Northeast Anaerobic Cell Landfill Gas Concentrations from Header Line

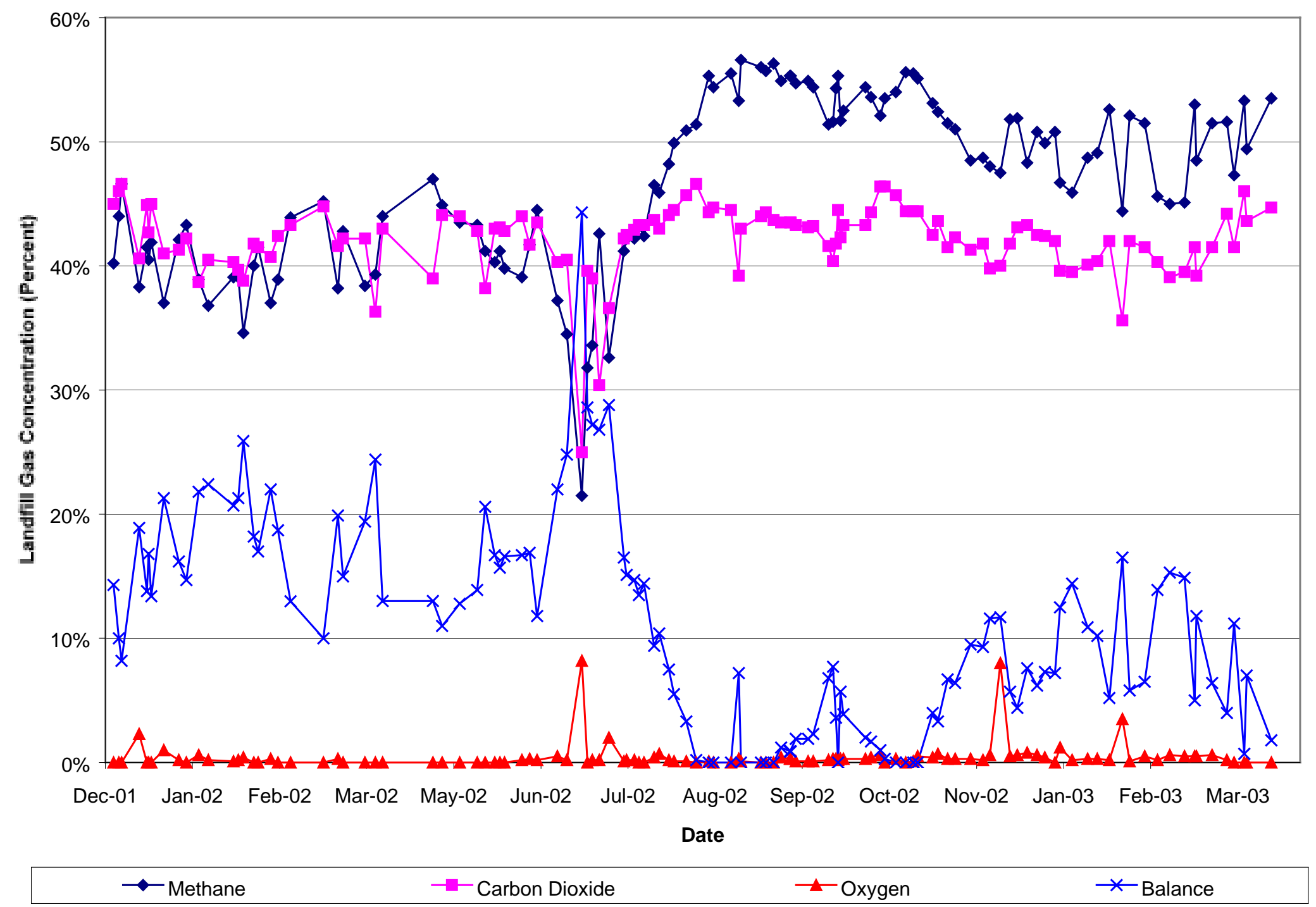


Figure 3-14. Northeast Anaerobic Cell Landfill Gas Flow Rate

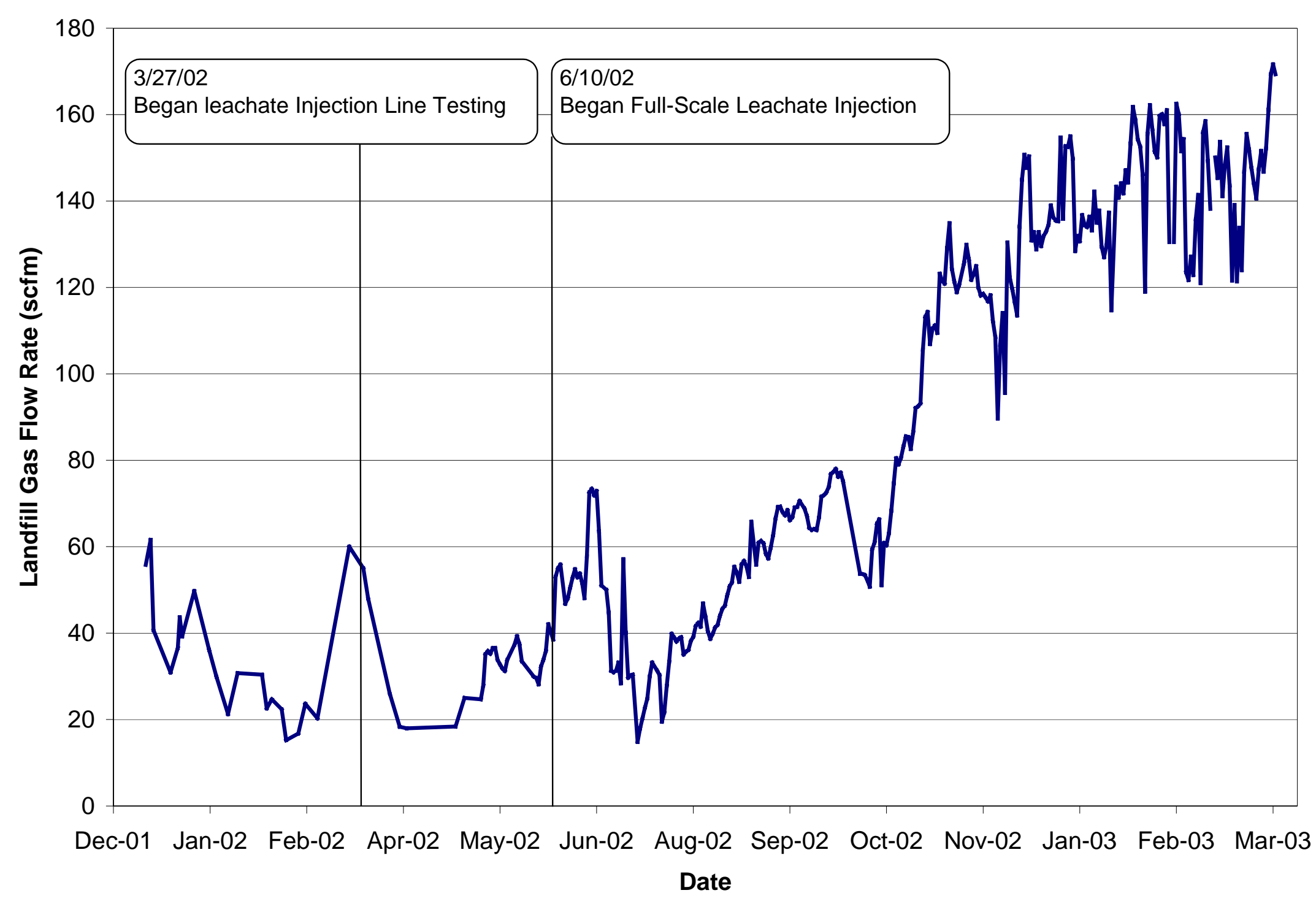




\section{Figure 3-15. Northeast Anaerobic Cell Cumulative Methane}

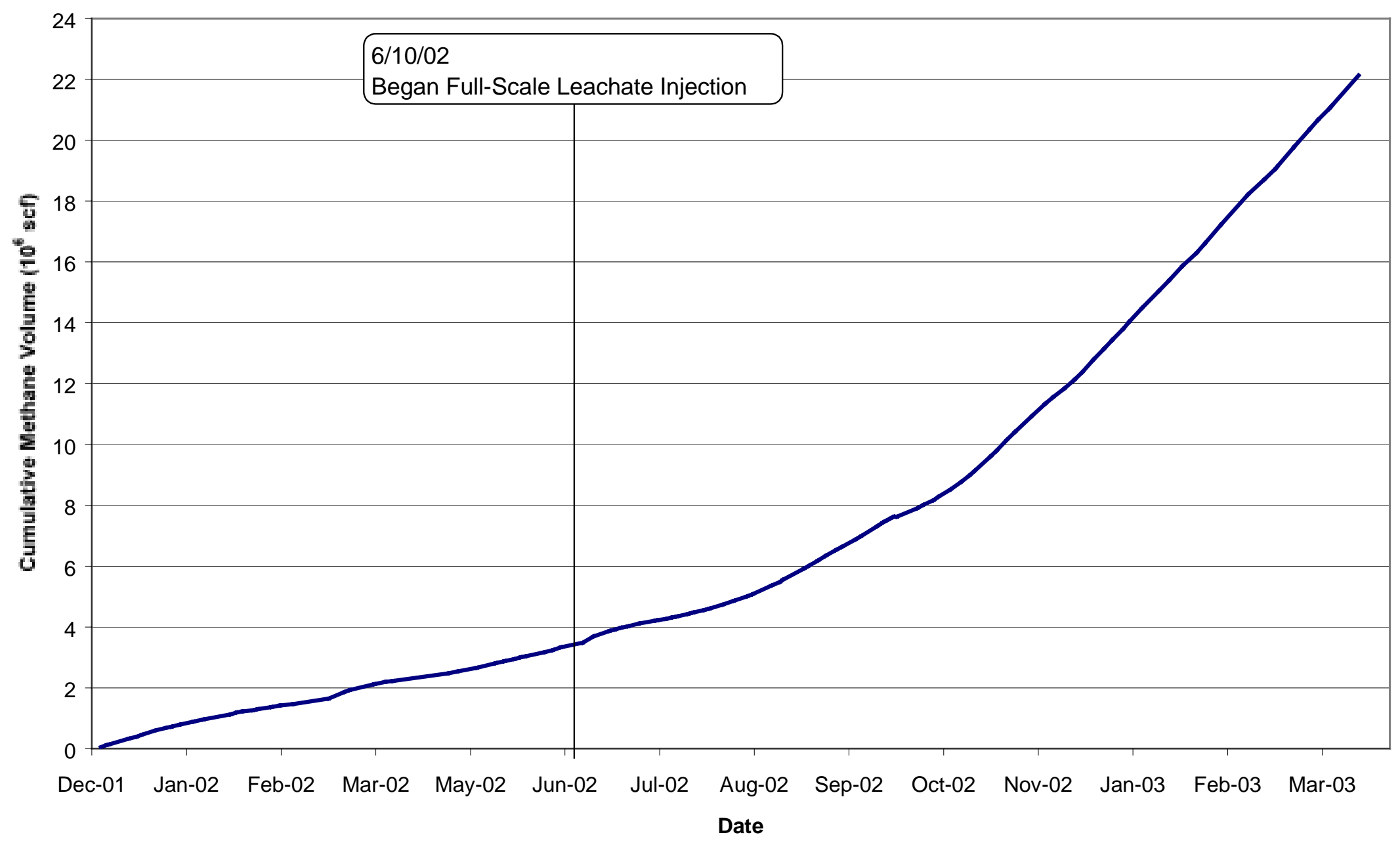


Figure 3-16. Cumulative Methane from the Northeast Anaerobic Cell and the Enhanced Cell from the Pilot Scale Project

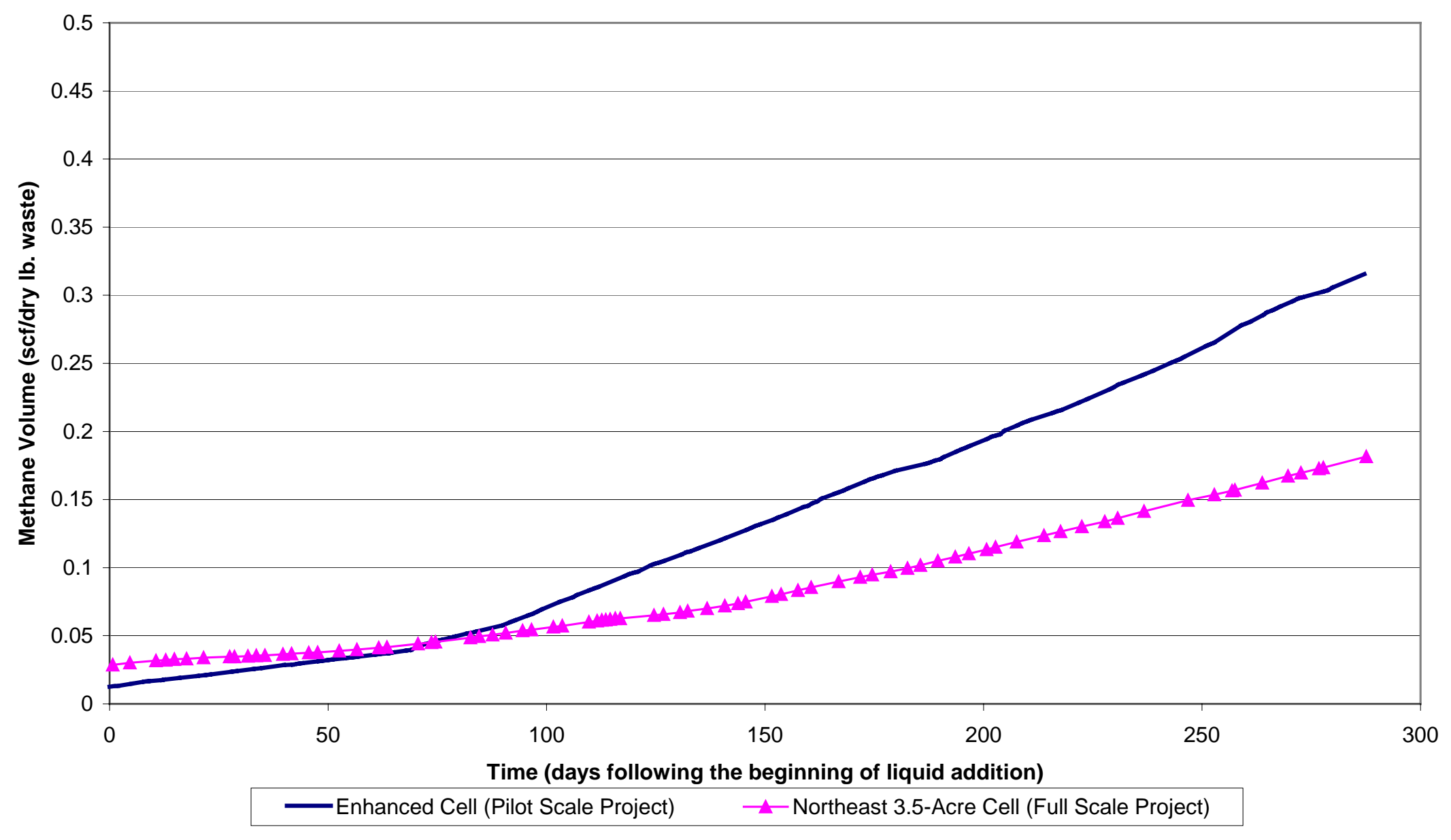


Figure 4-1. West-Side Anaerobic Cell Layer 1 Temperature Readings

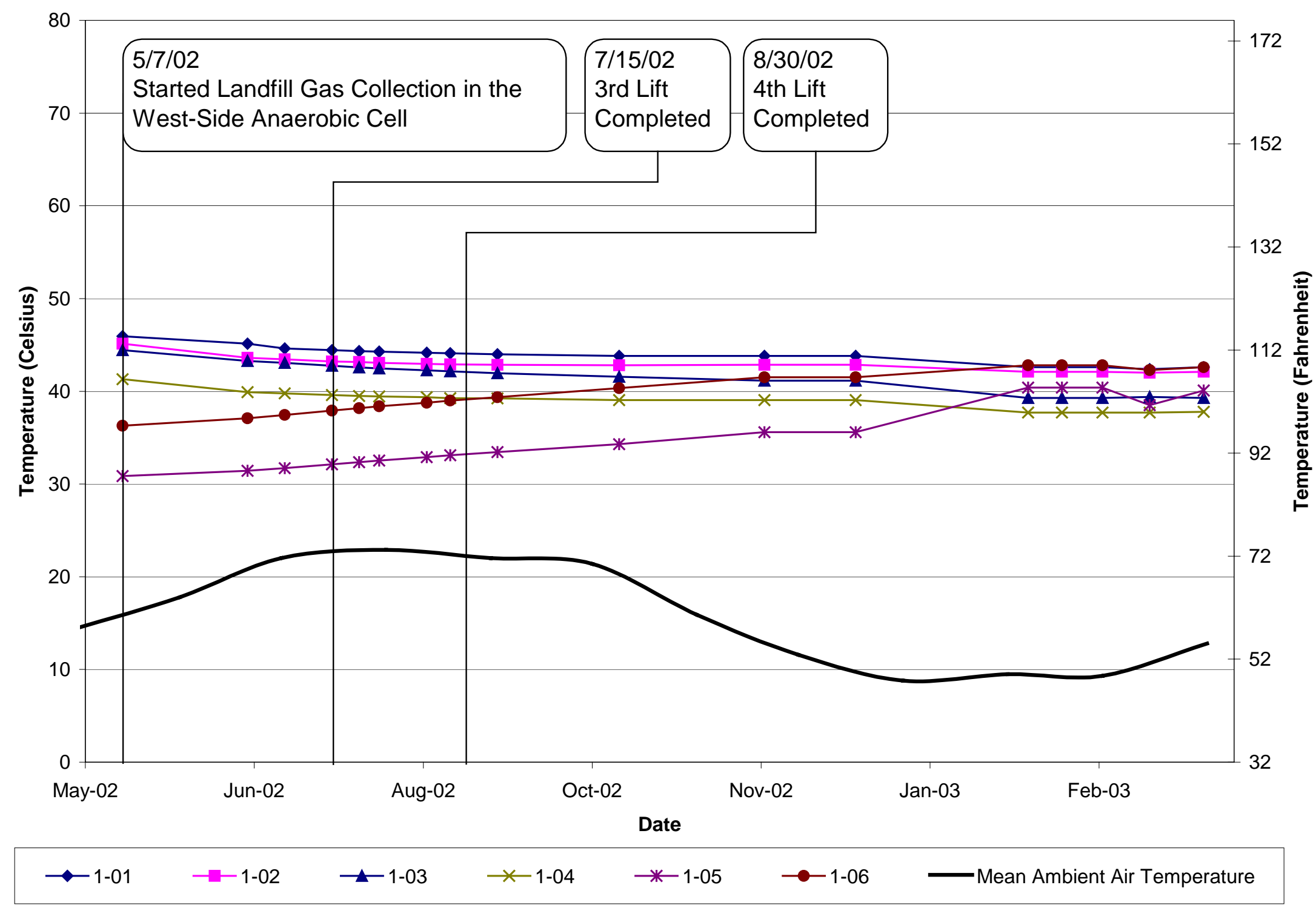


Figure 4-2. West-Side Anaerobic Cell Layer 2 Temperature Readings

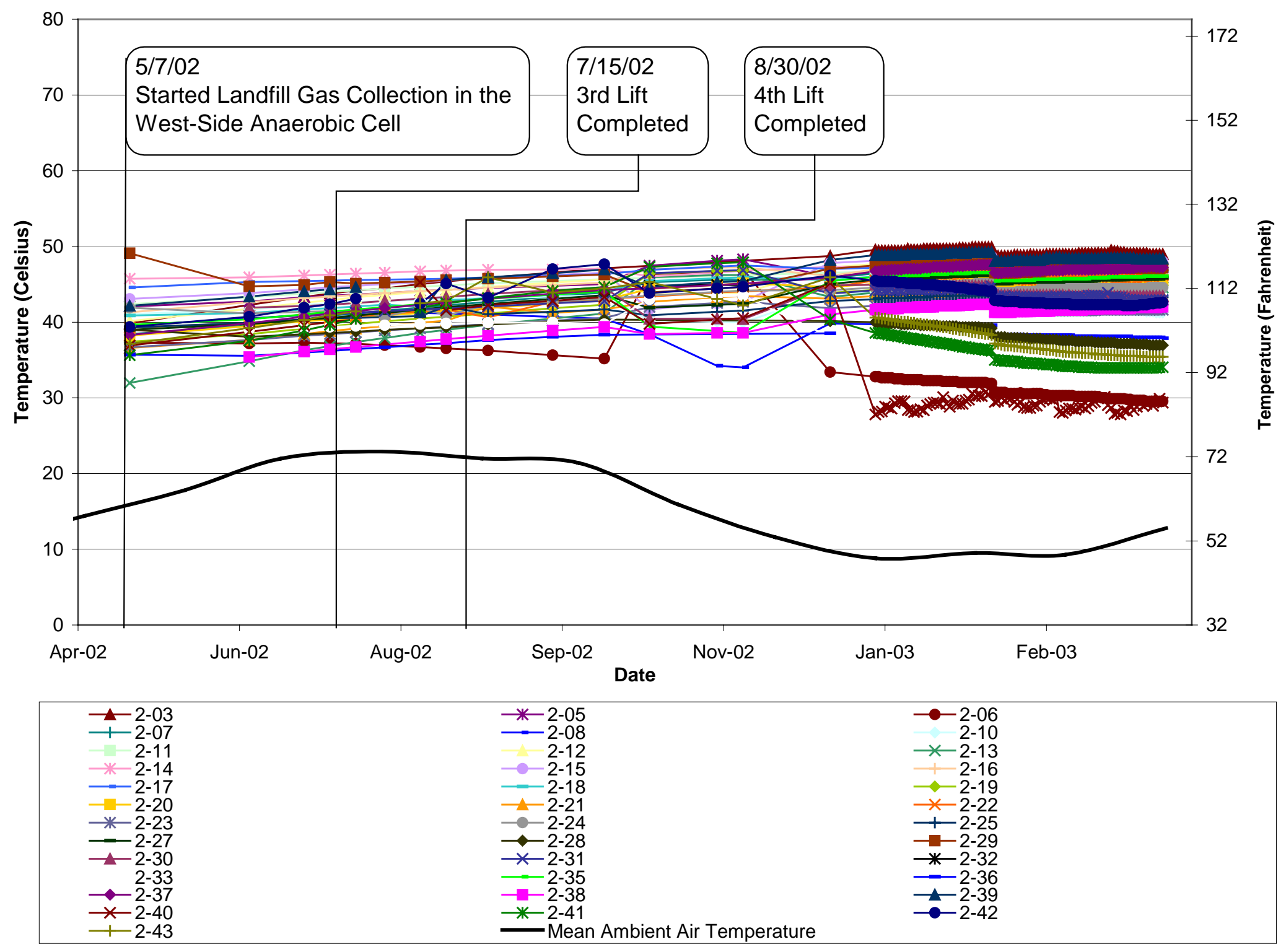


Figure 4-3. West-Side Anaerobic Cell Layer 3 Temperature Readings

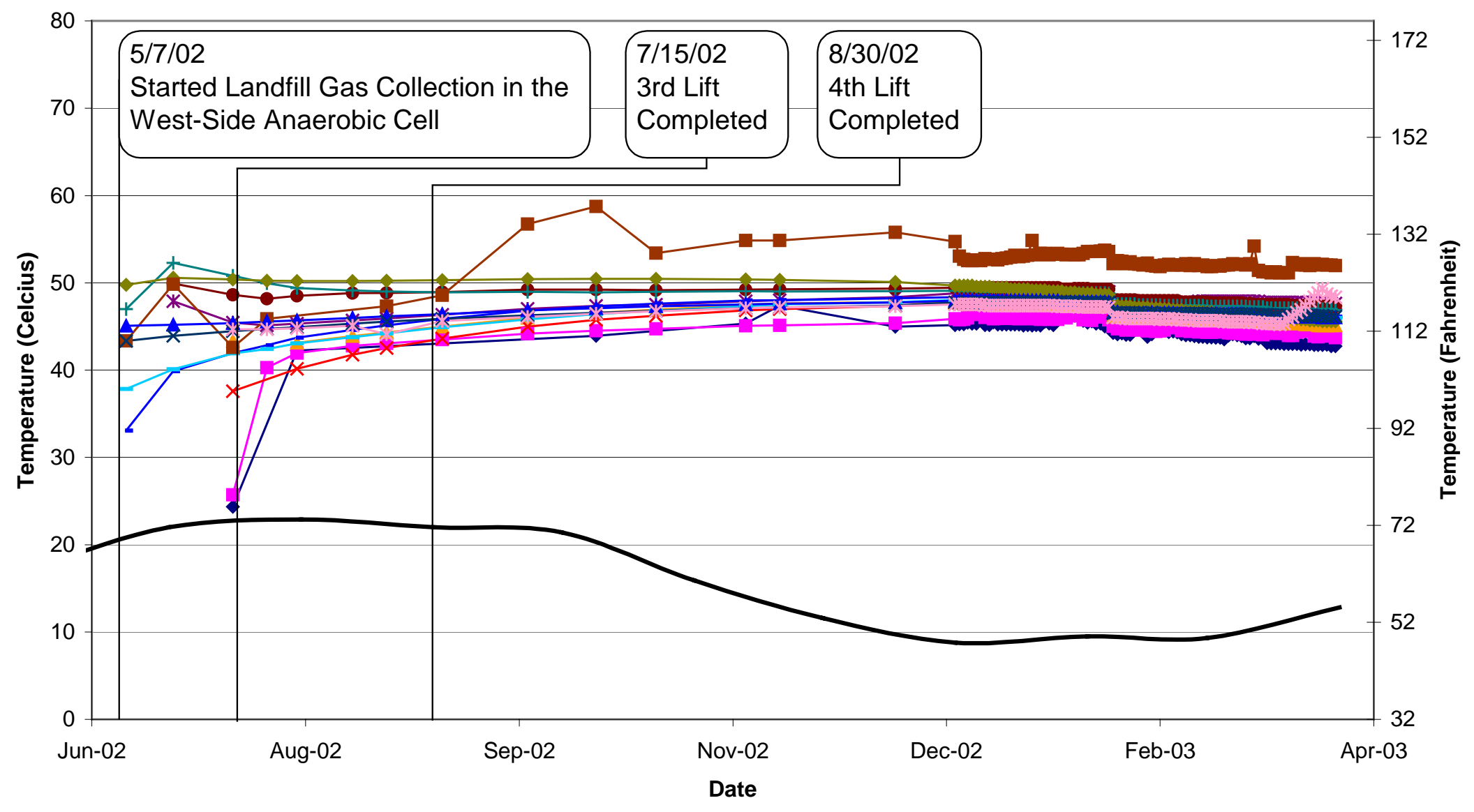

\begin{tabular}{|c|c|c|}
\hline $\begin{array}{r}r-3-01 \\
\times \quad 3-04 \\
+3-07 \\
-\quad 3-10 \\
\times \quad 3-13\end{array}$ & $\begin{array}{l}-3-02 \\
\rightarrow-3-05 \\
--3-08 \\
--3-11 \\
-3-14\end{array}$ & $\begin{array}{r}-3-03 \\
--3-06 \\
-3-09 \\
--3-12 \\
- \text { Mean Ambient Air Temperature }\end{array}$ \\
\hline
\end{tabular}


Figure 4-5. West-Side Anaerobic Cell Layer 1 PVC Moisture Readings

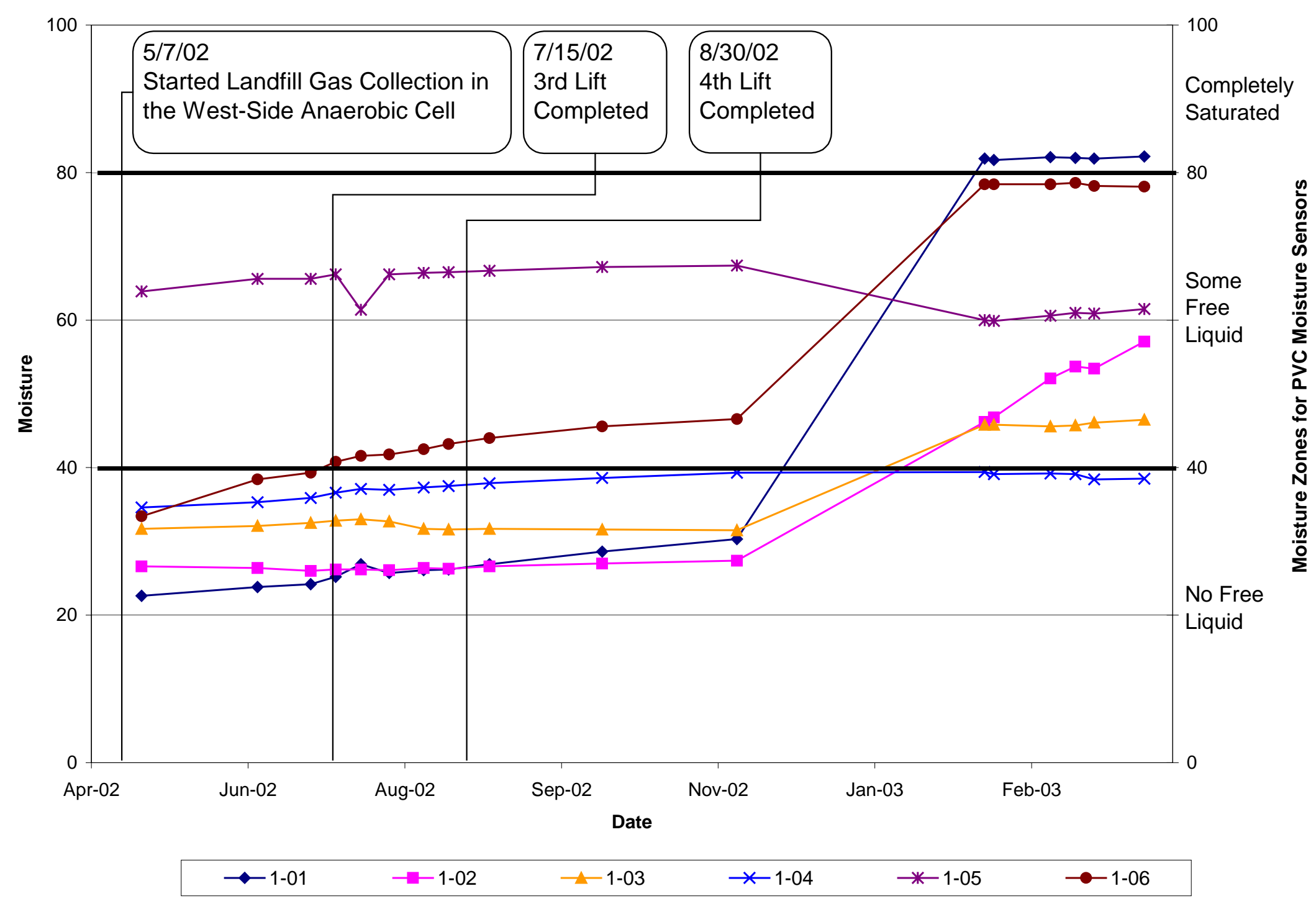


Figure 4-6. West-Side Anaerobic Cell Layer 2 PVC Readings

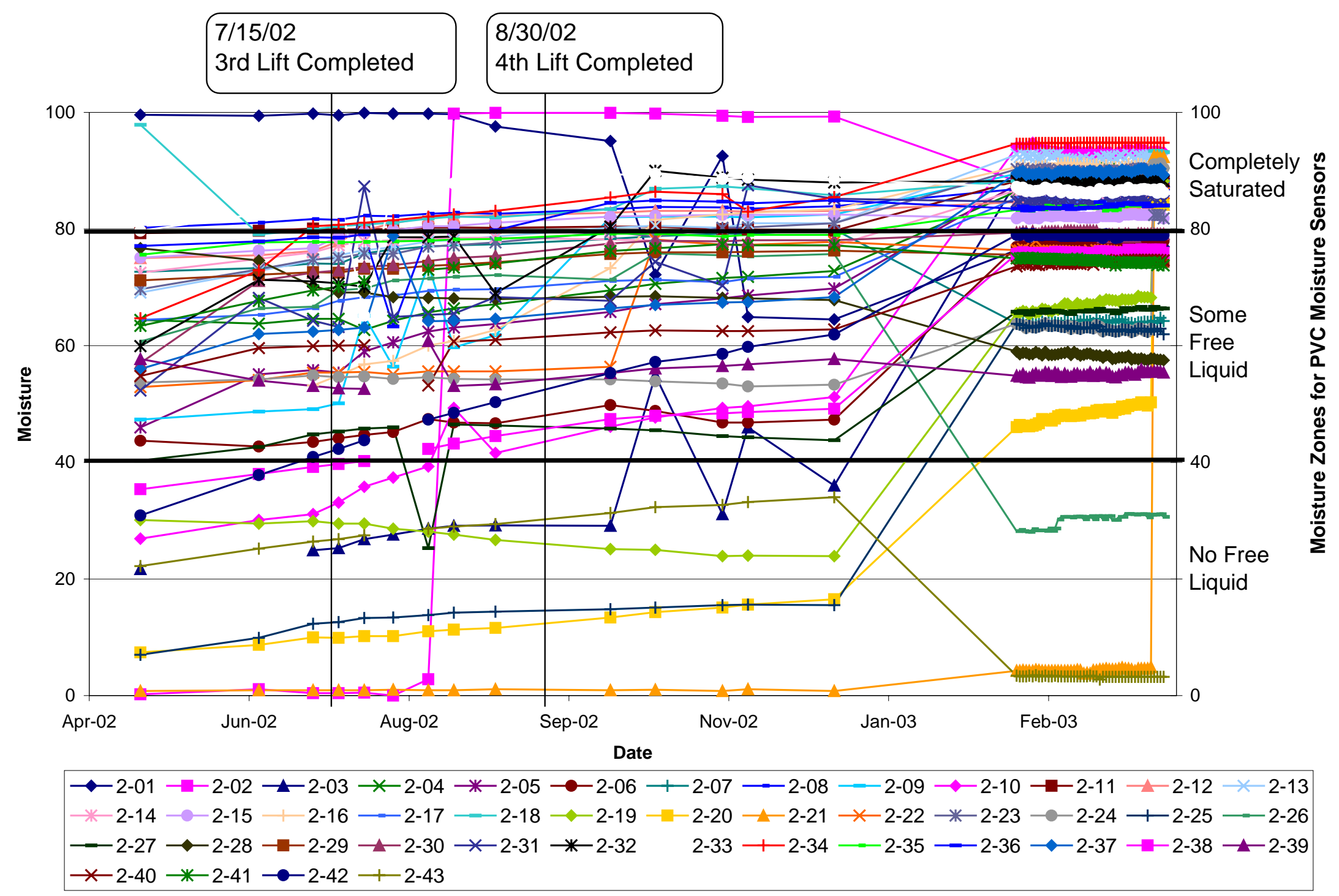


Figure 4-7. West-Side Anaerobic cell Layer 3 PVC Moisture Readings

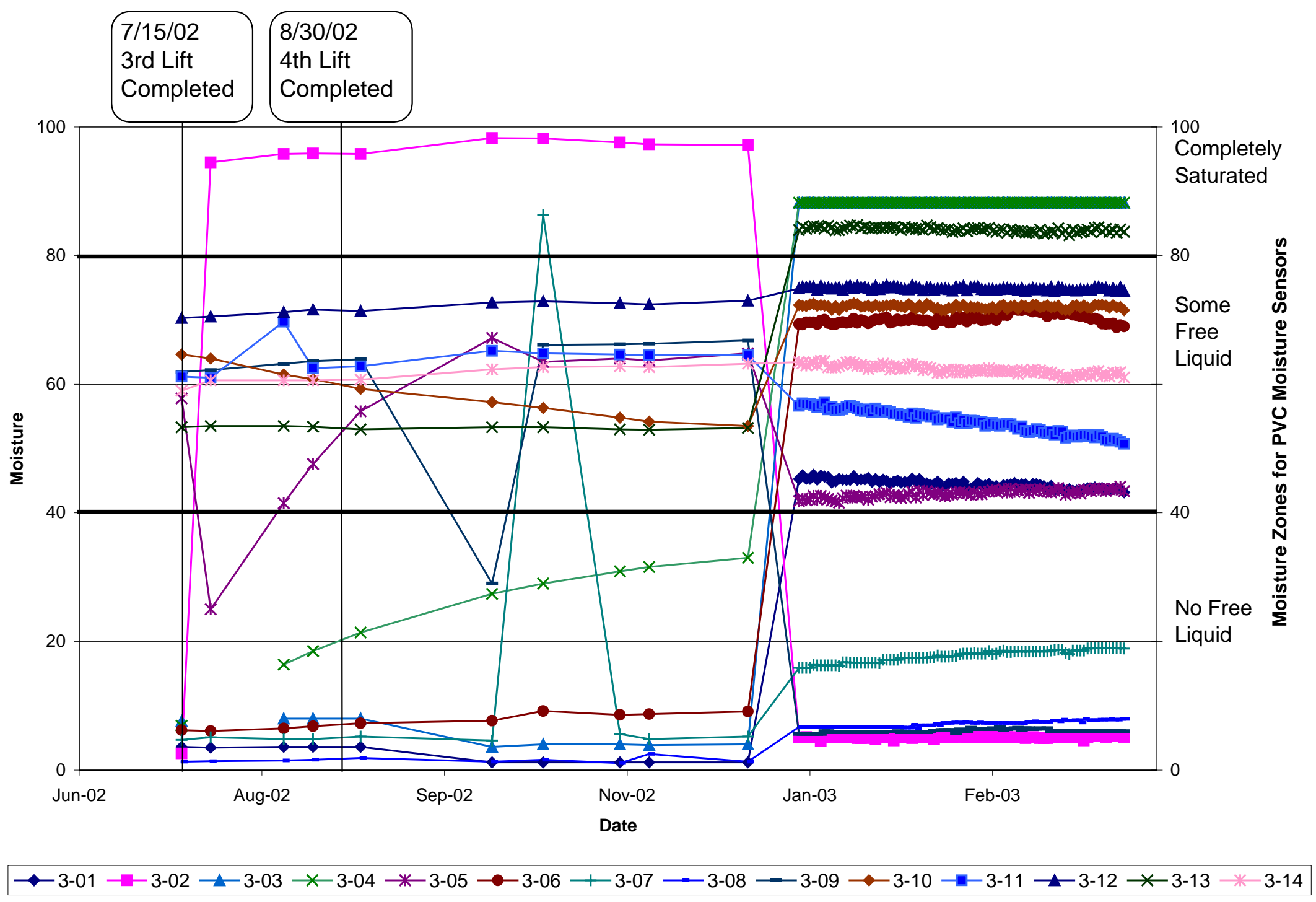


Figure 4-9. West-Side Anaerobic Cell Landfill Gas Concentrations from Header Line

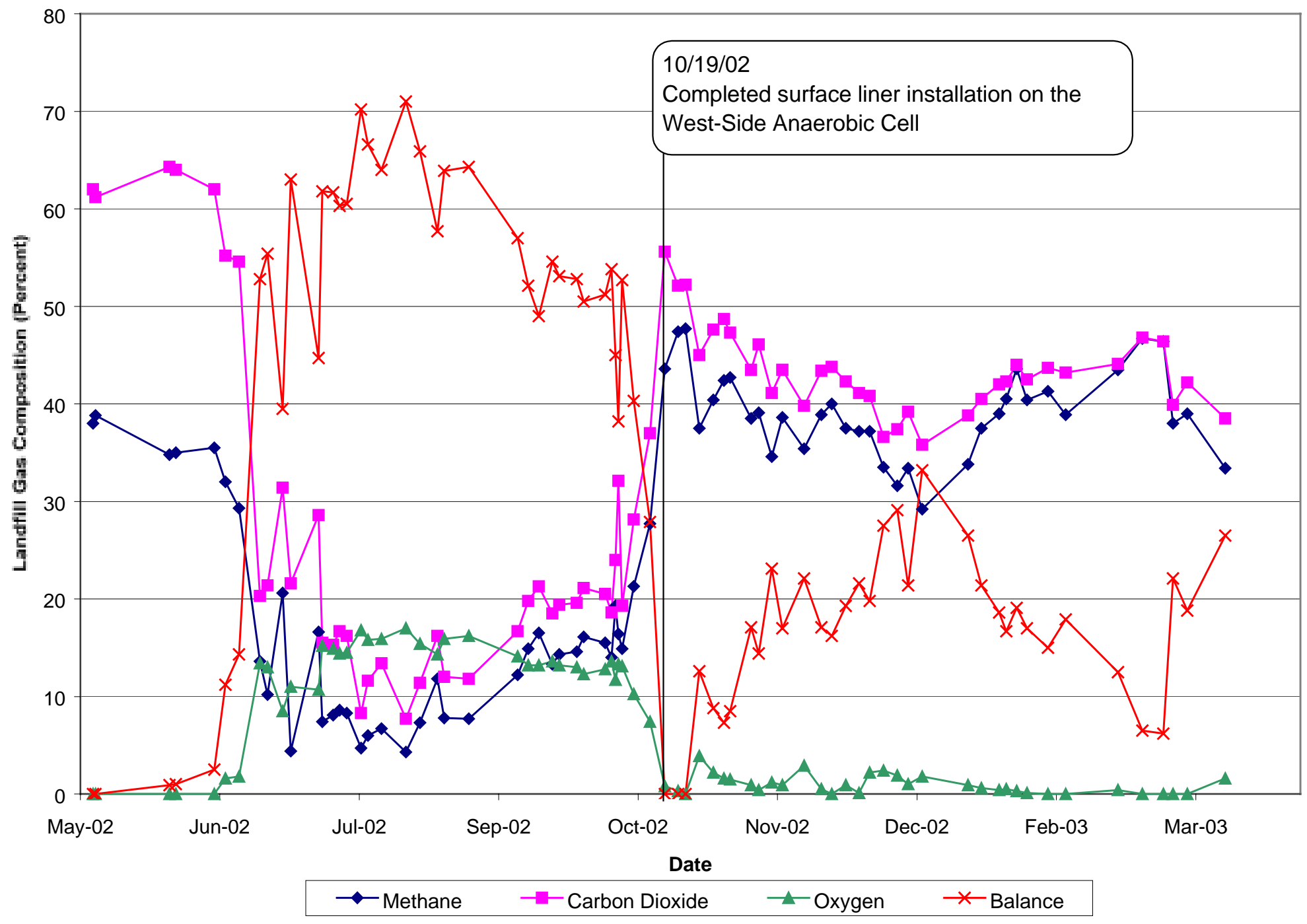


Figure 4-10. West-Side Anaerobic Cell Landfill Gas Flow Rate

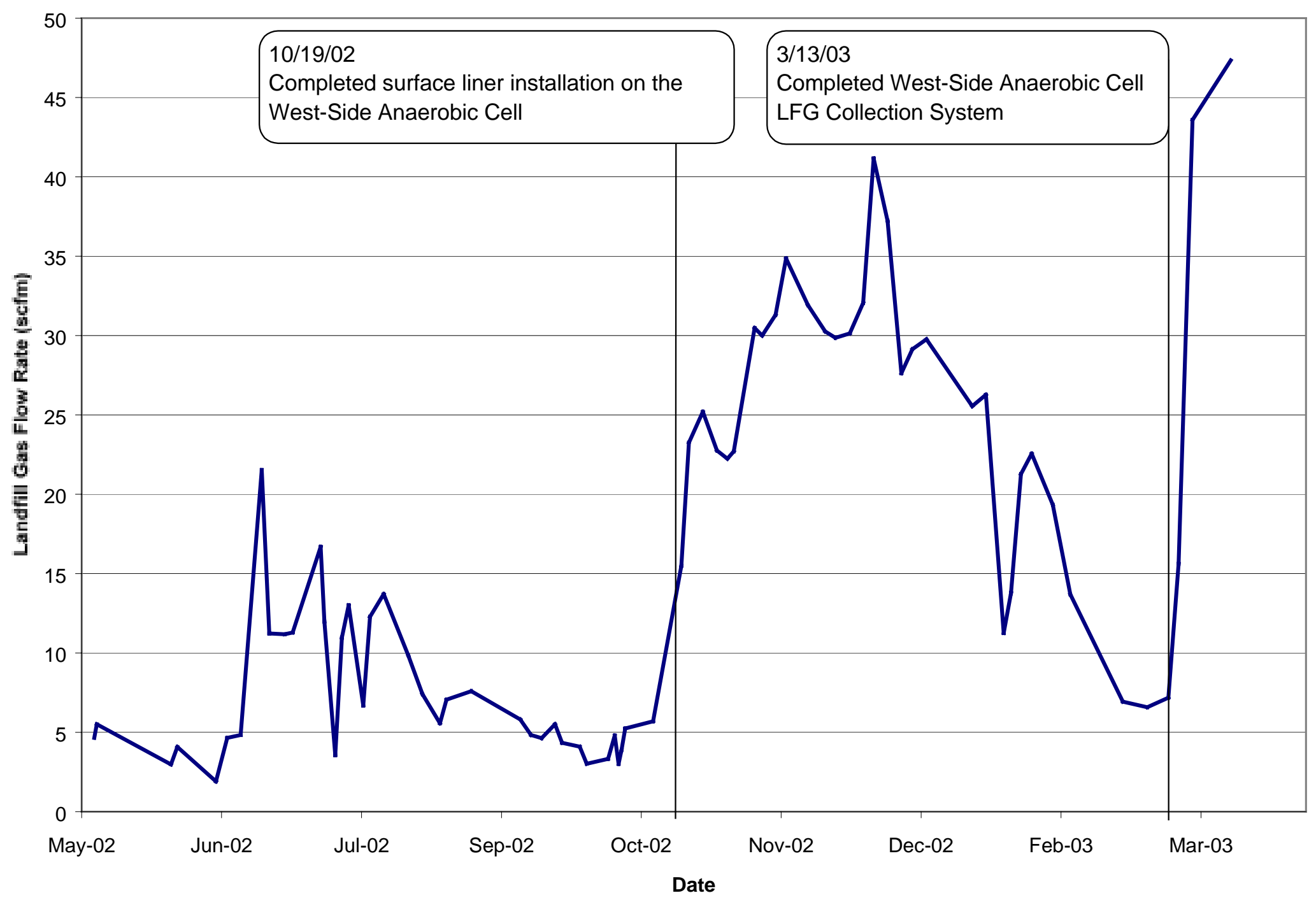


Figure 4-11. West-Side Anaerobic Cell Cumulative Methane

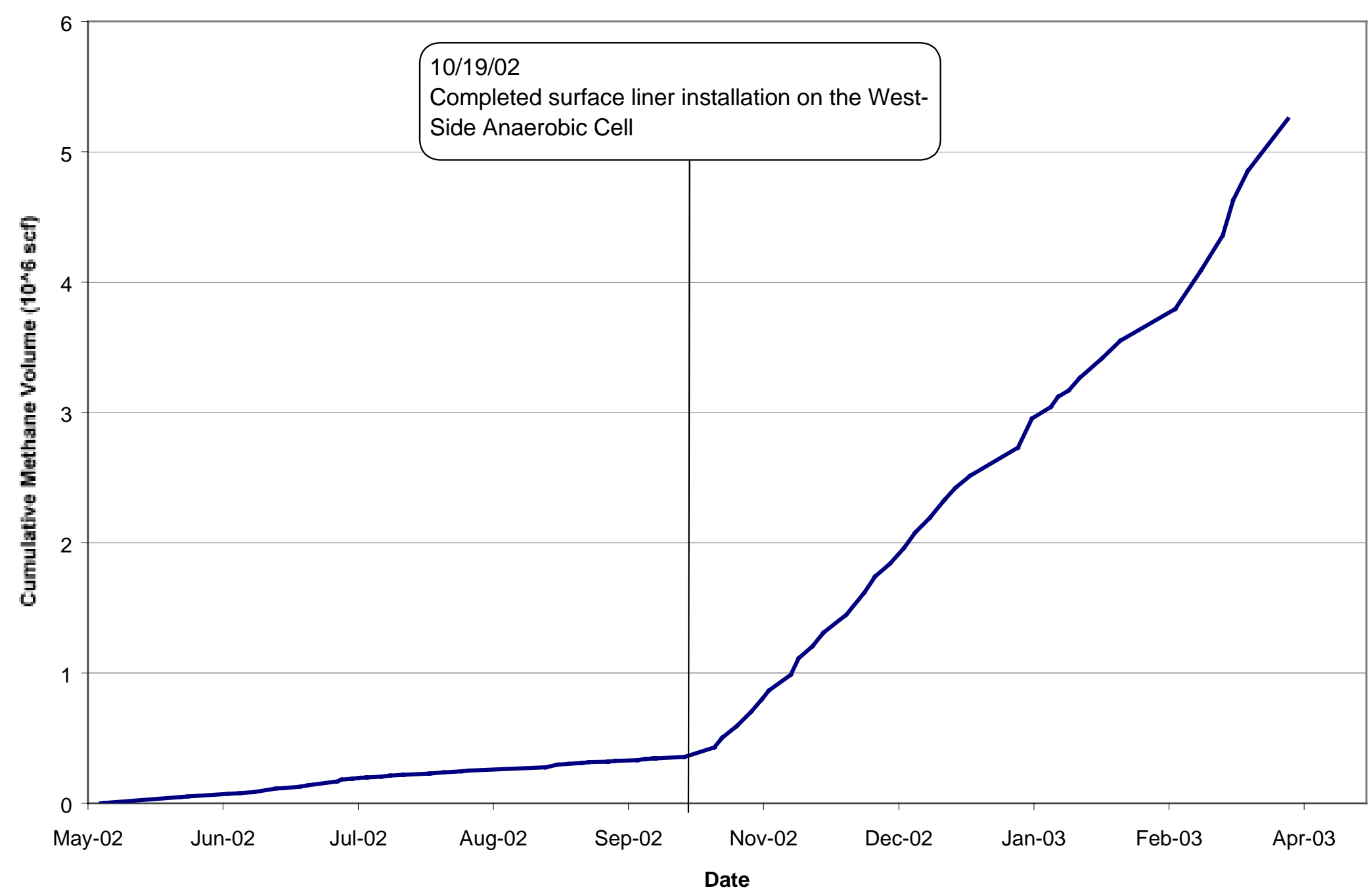


Figure 4-12. Cumulative Leachate Removed from the West-Side Leachate Collection and Removal System (LCRS)

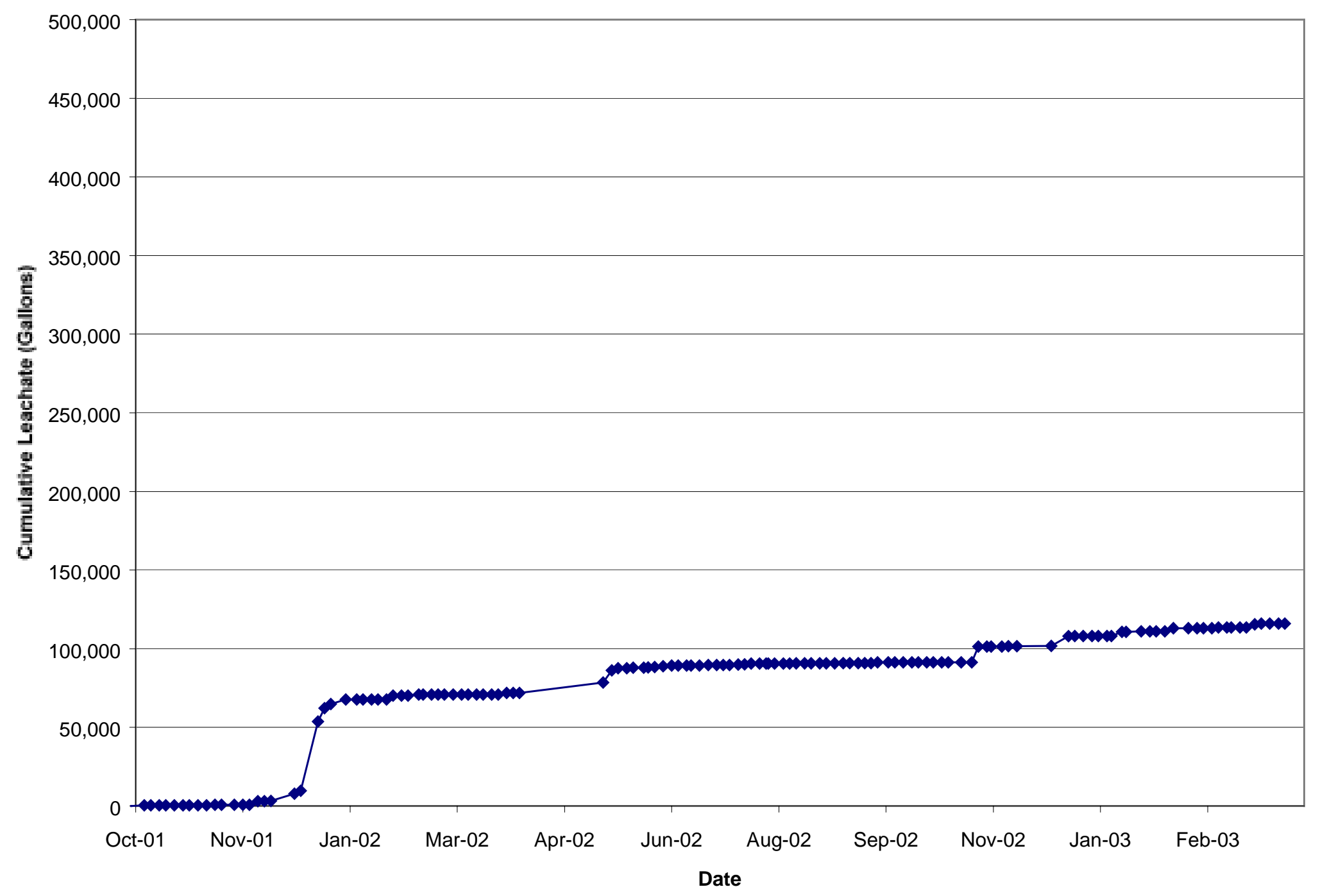


Figure 5-1. Aerobic Cell Base Liner Temperature Readings

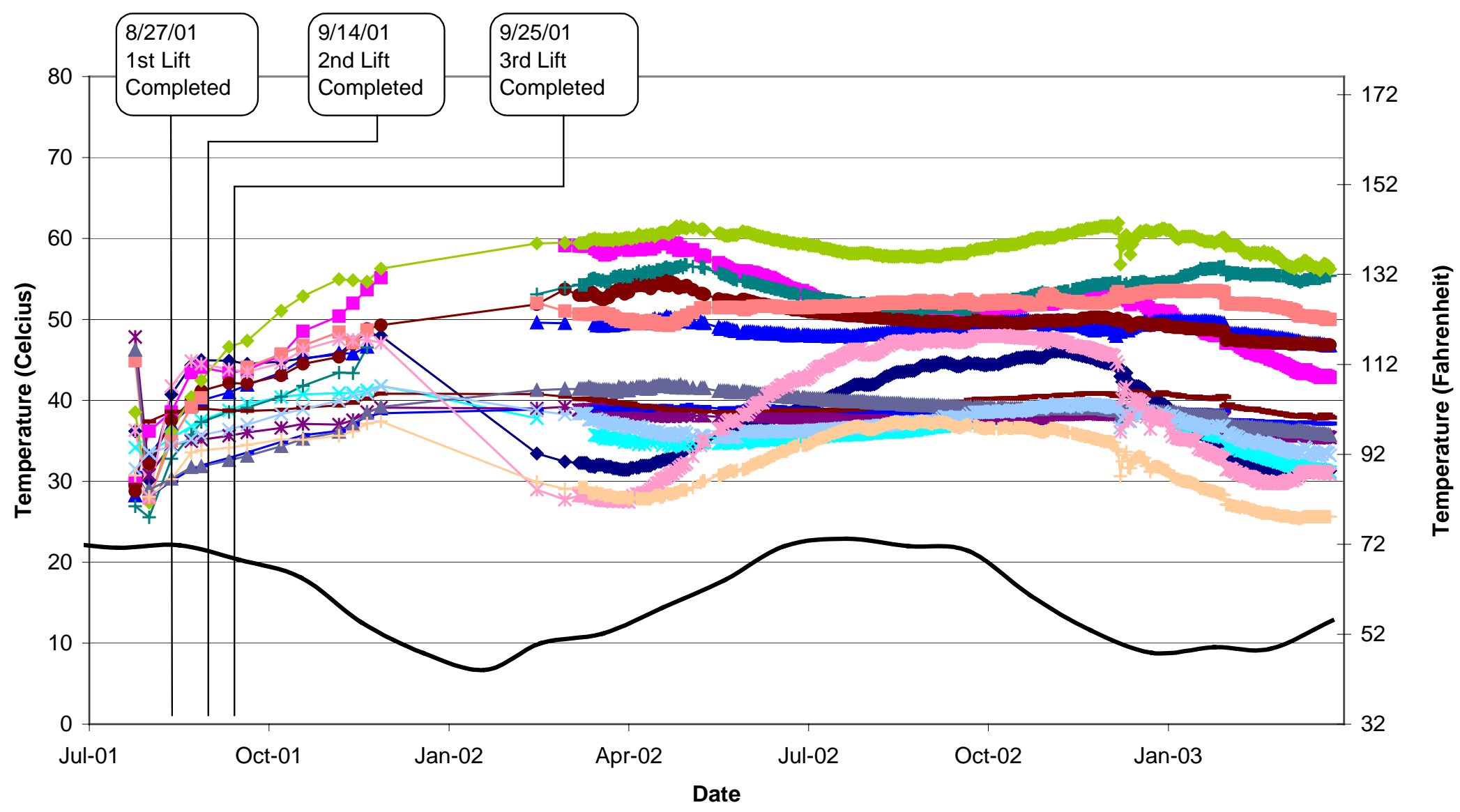

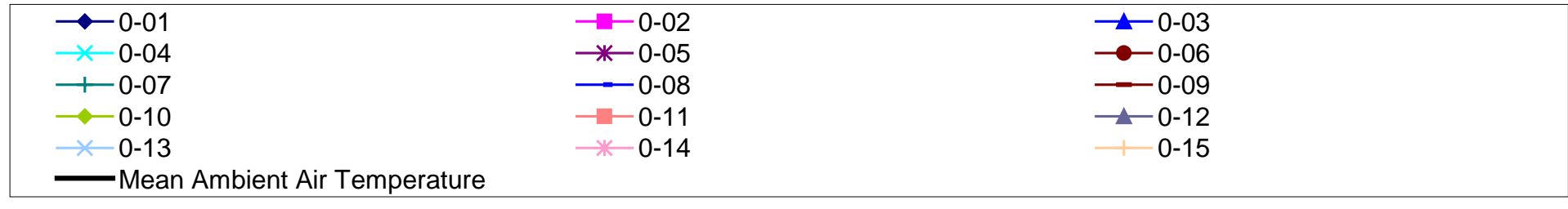


Figure 5-2. Aerobic Cell Layer 0.5 Temperature Readings

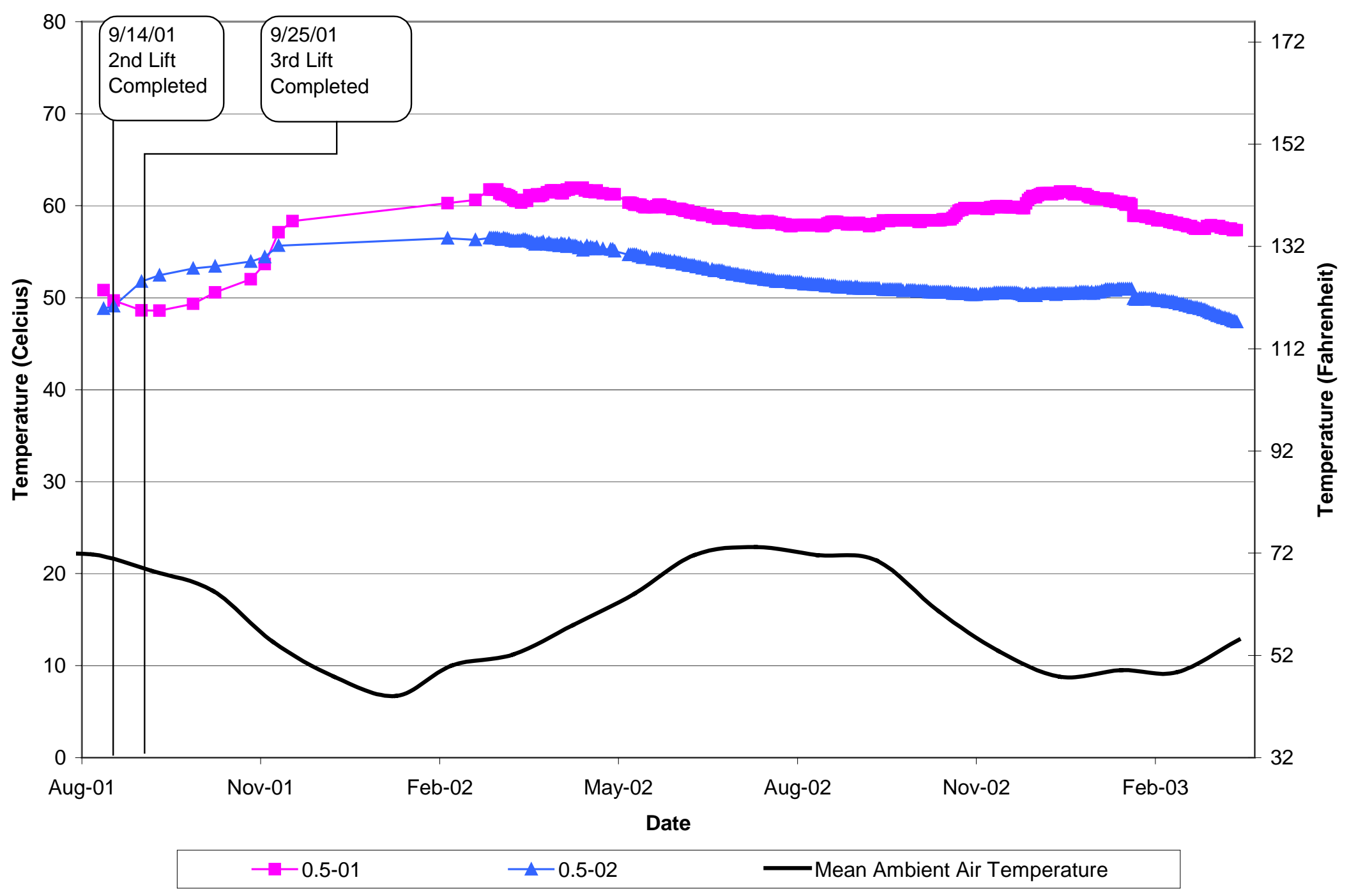


Figure 5-3. Aerobic Cell Layer 1 Temperature Readings

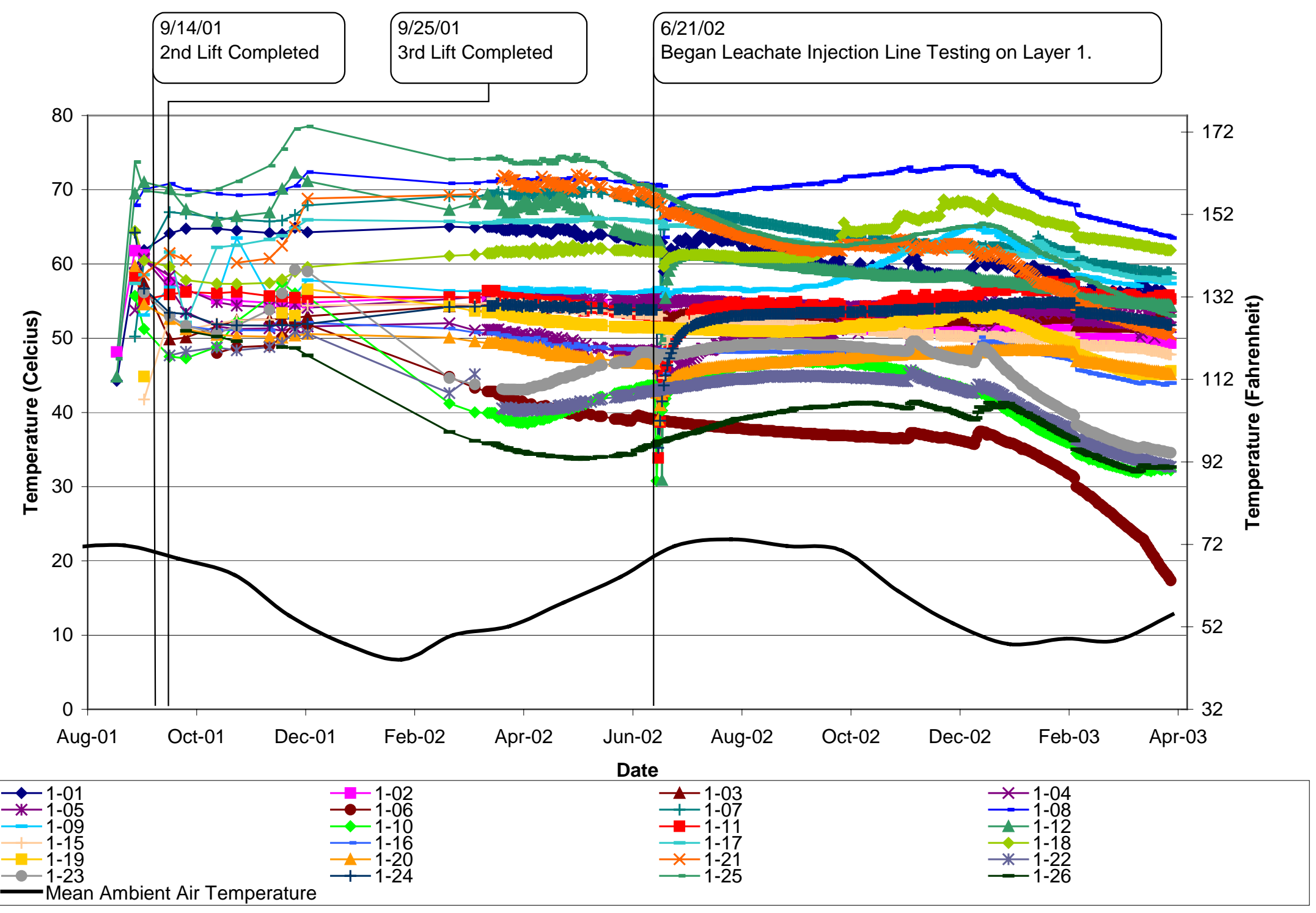


Figure 5-4. Aerobic Cell Layer 2 Temperature Readings

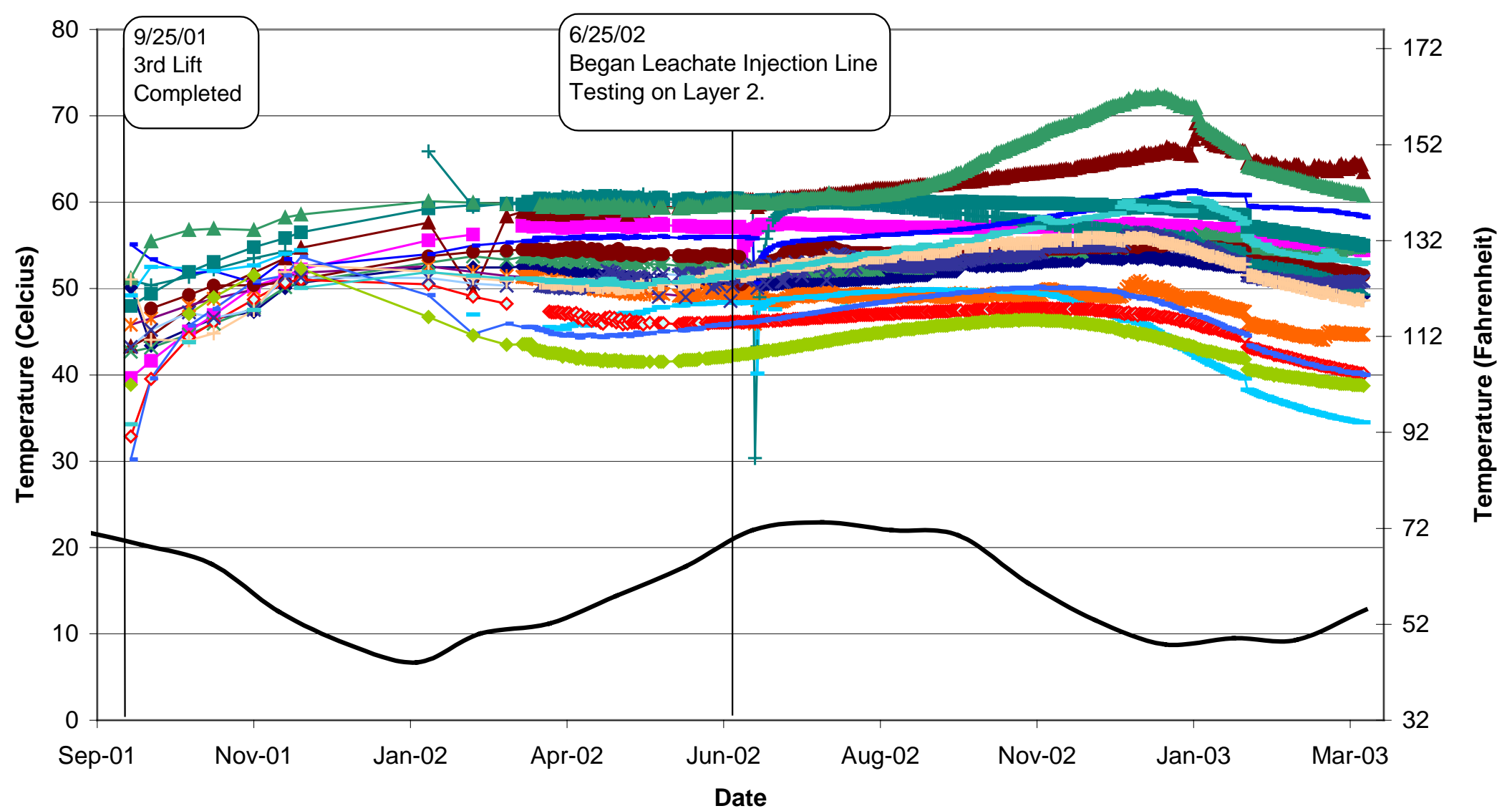

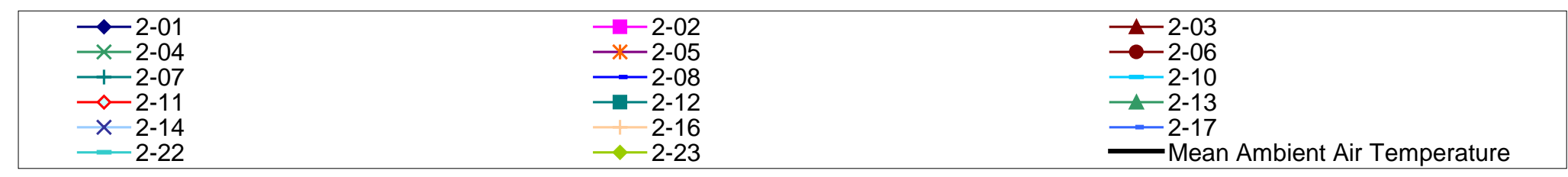


Figure 5-6. Aerobic Cell Base Liner PVC Moisture Readings

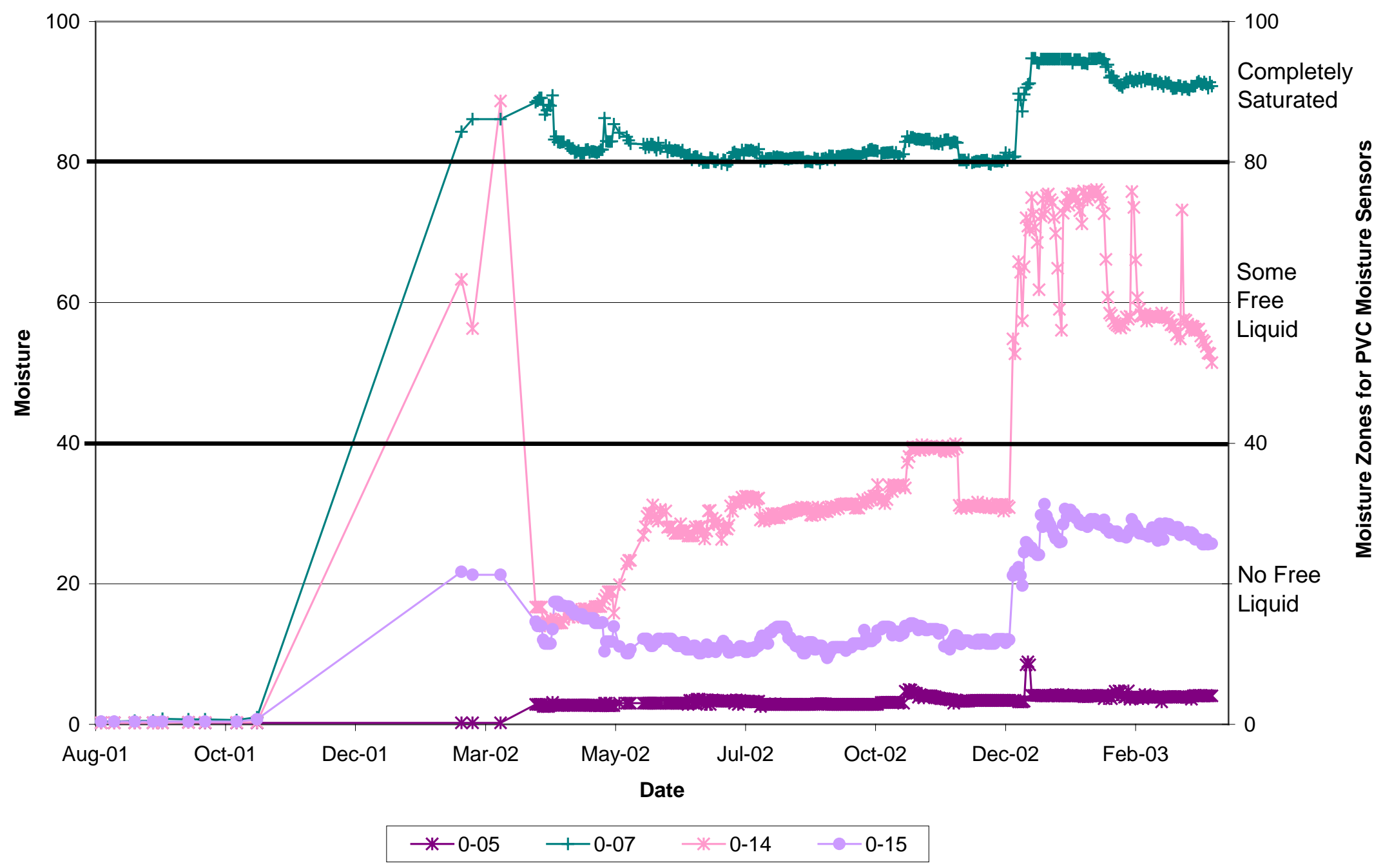


Figure 5-7. Aerobic Cell Layer 0.5 PVC Moisture Readings

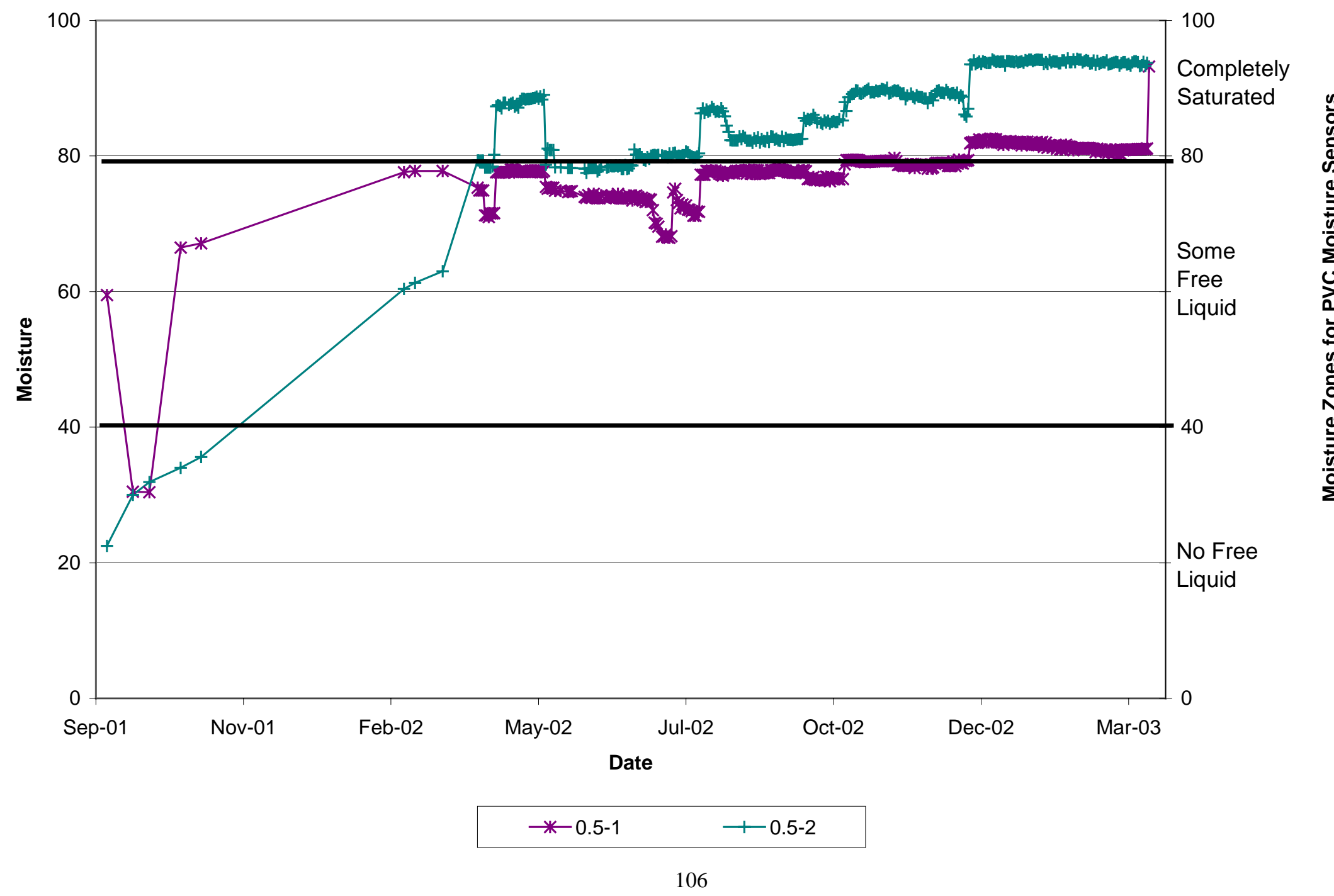


Figure 5-8. Aerobic Cell Layer 1 PVC Moisture Readings

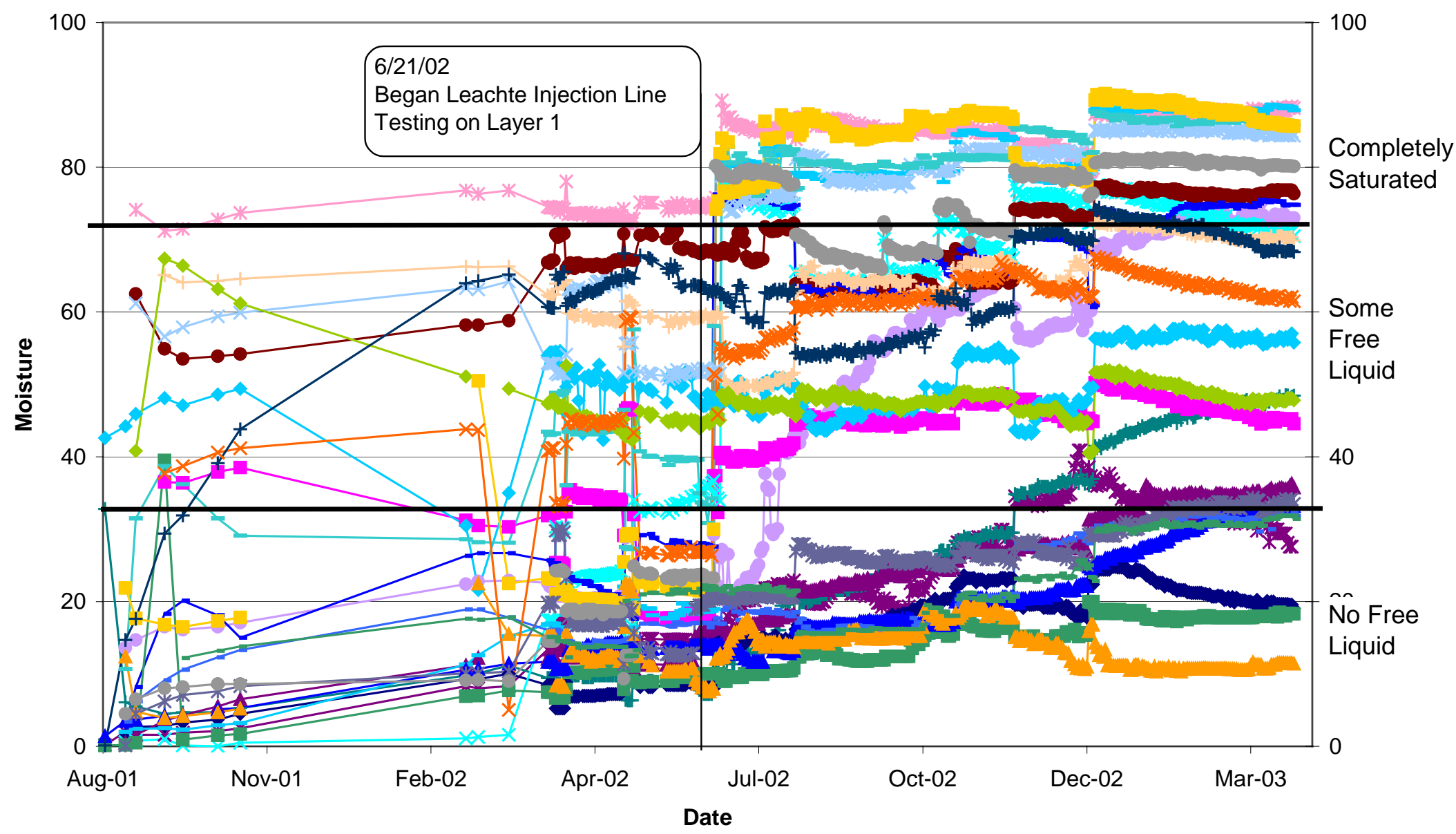

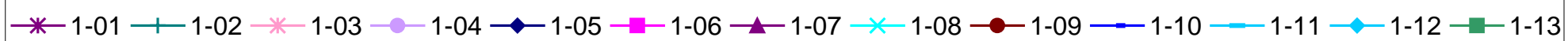

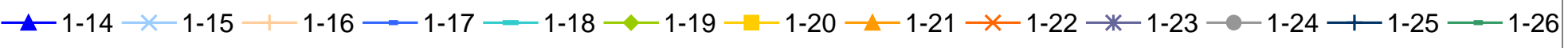


Figure 5-9. Aerobic Cell Layer 2 PVC Moisture Readings

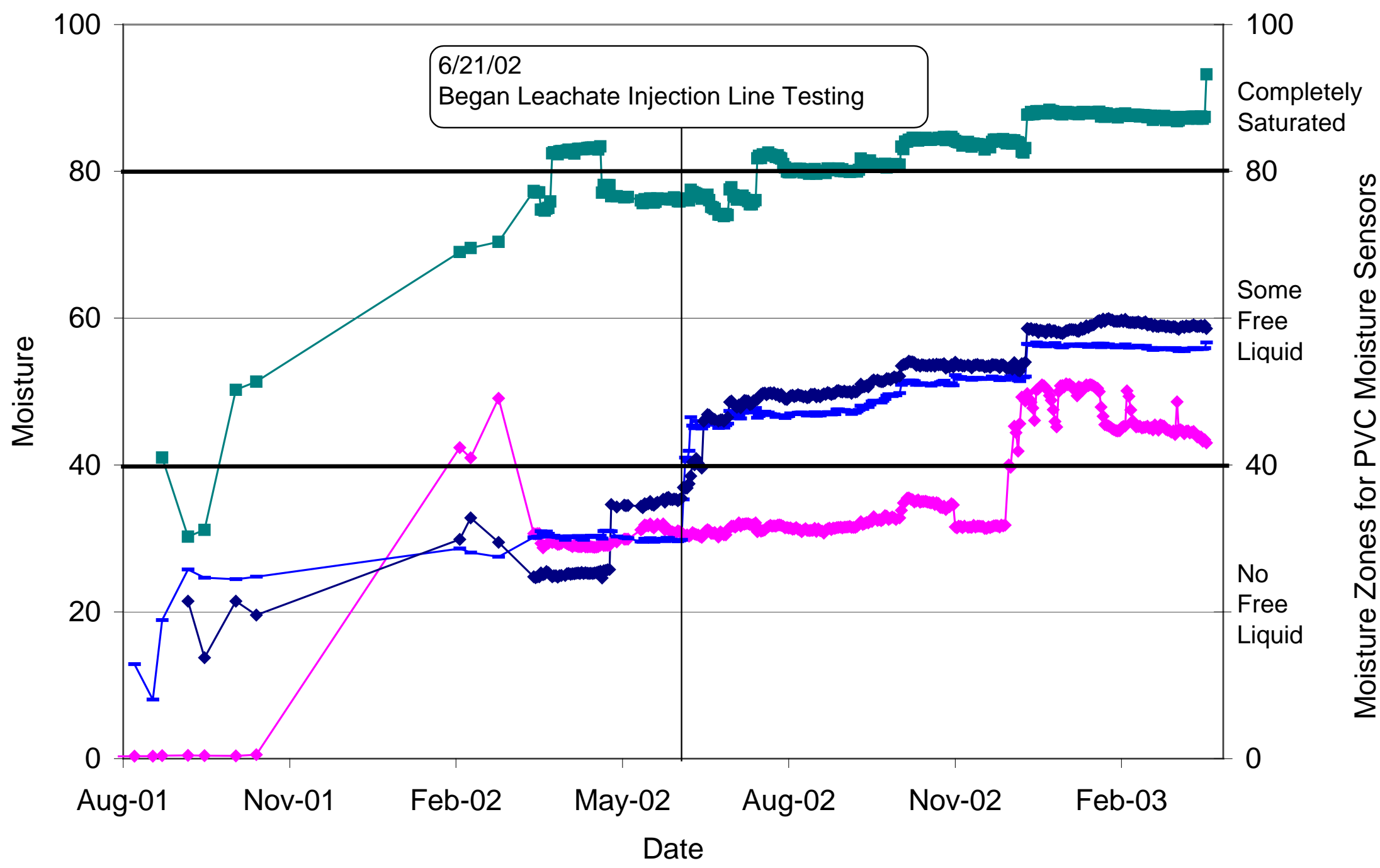

$\rightarrow$ Layer $0 \quad \rightarrow$ Layer $0.5 \quad-$ Layer $1 \quad \rightarrow$ Layer 2


Figure 6-1. Module D Base Liner Temperature Readings (Northwest Quadrant)

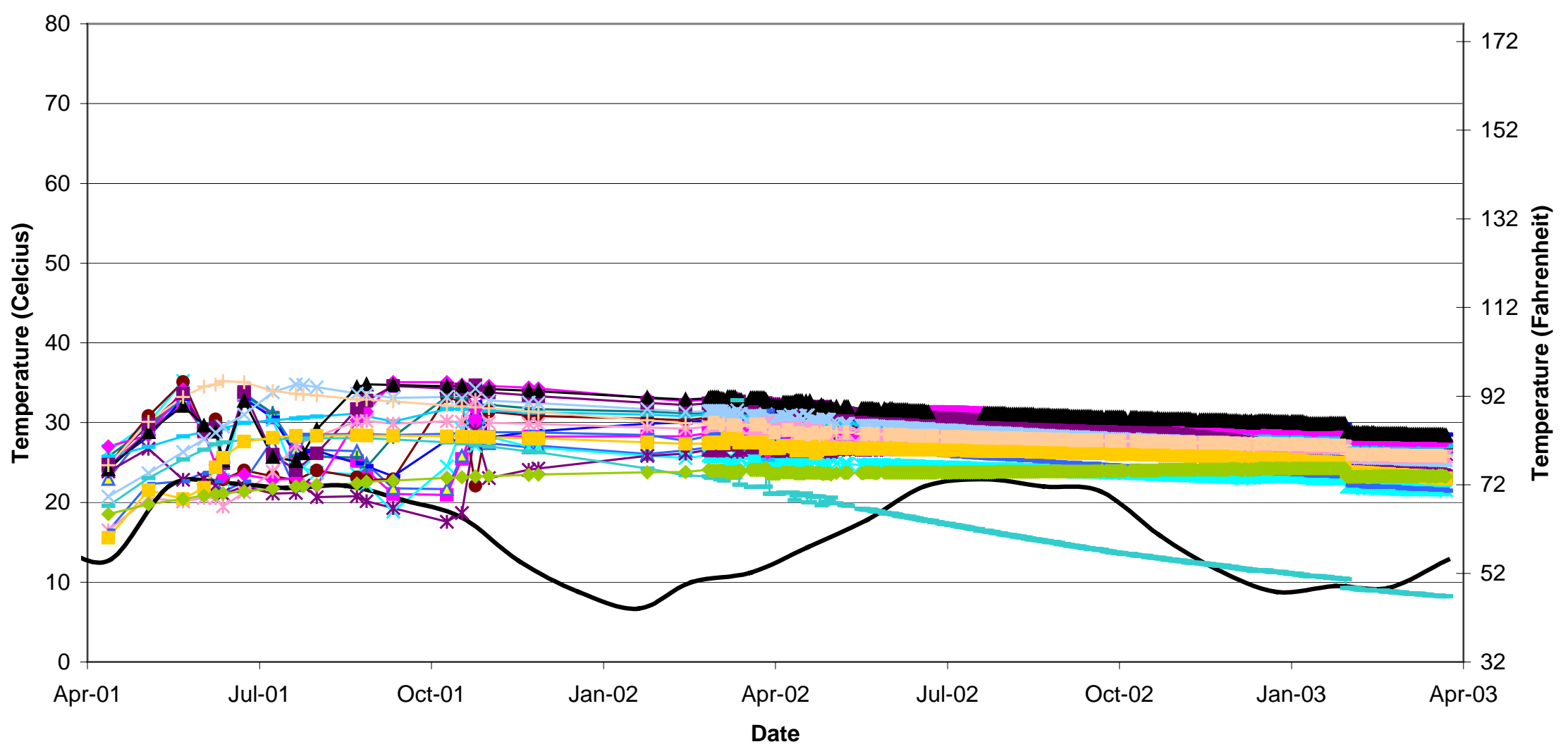

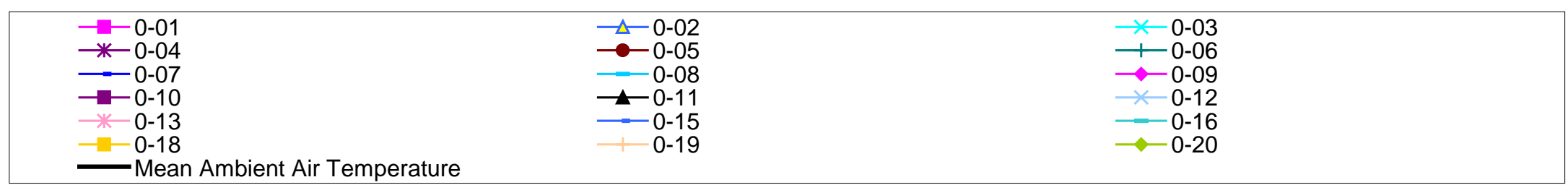


Figure 6-2. Module D Base Liner Temperature Readings (Southwest Quadrant)

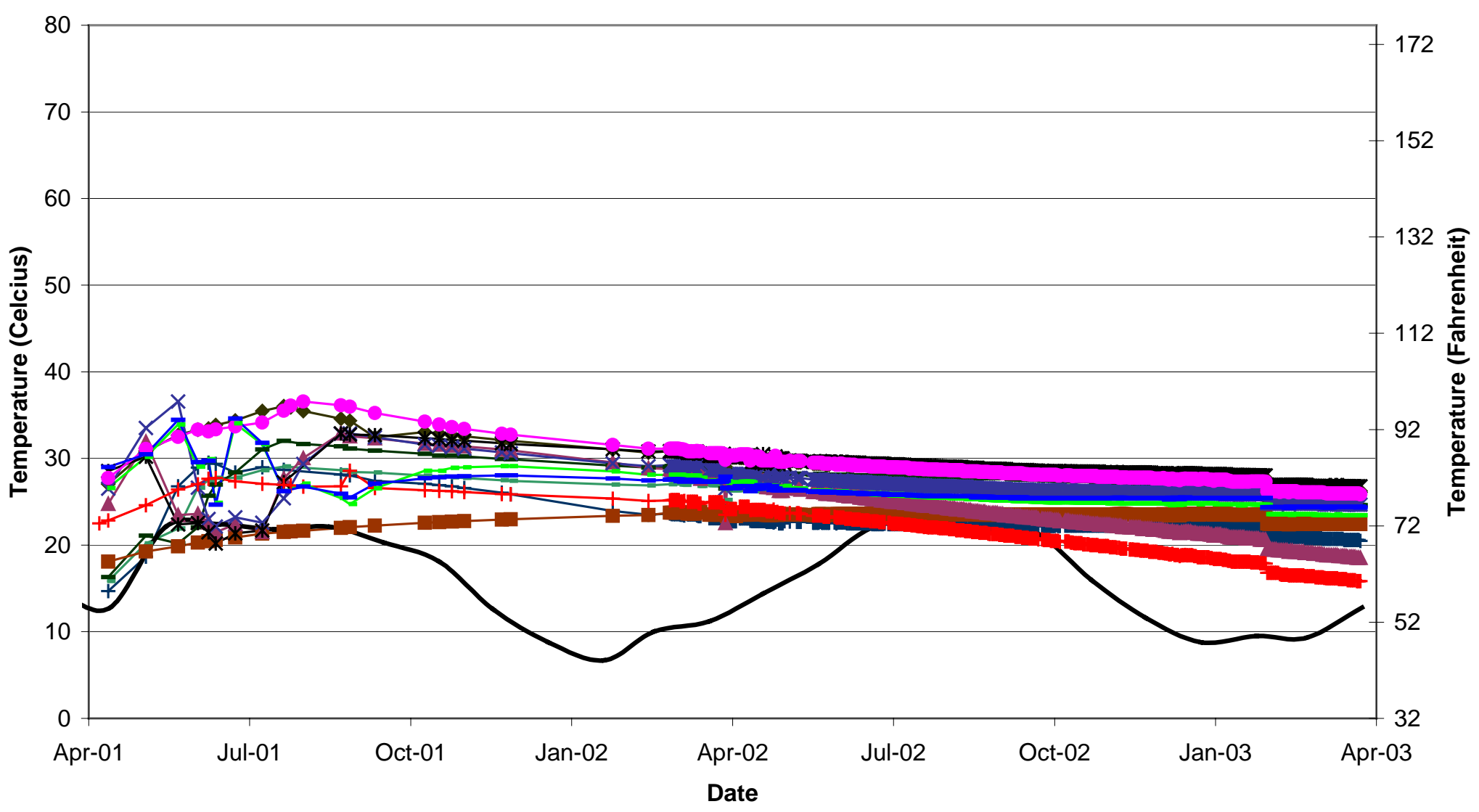

\begin{tabular}{|c|c|c|}
\hline$-0-21$ & $=-0-22$ & $-0-23$ \\
\hline$\neg 0-24$ & $\rightarrow-0-25$ & $-0-26$ \\
\hline$\times 0-27$ & $\rightarrow 0-28$ & $\rightarrow 0-29$ \\
\hline$-0-30$ & $=0-31$ & $-0-32$ \\
\hline
\end{tabular}


Figure 6-3. Module D Base Liner Temperature Readings (Northeast Quadrant)

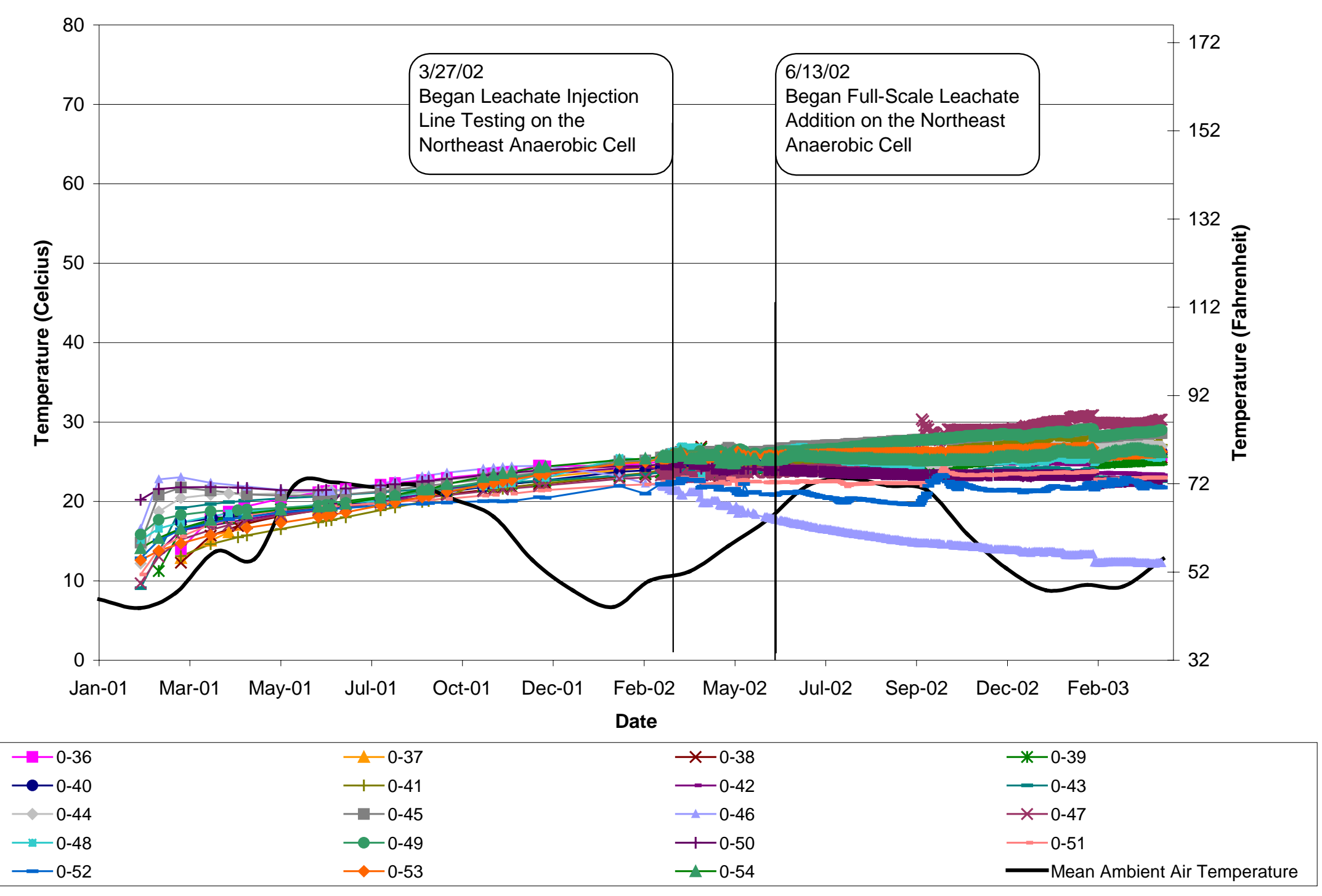


Figure 6-4. Module D Base Liner Temperature Readings (Southeast Quadrant)

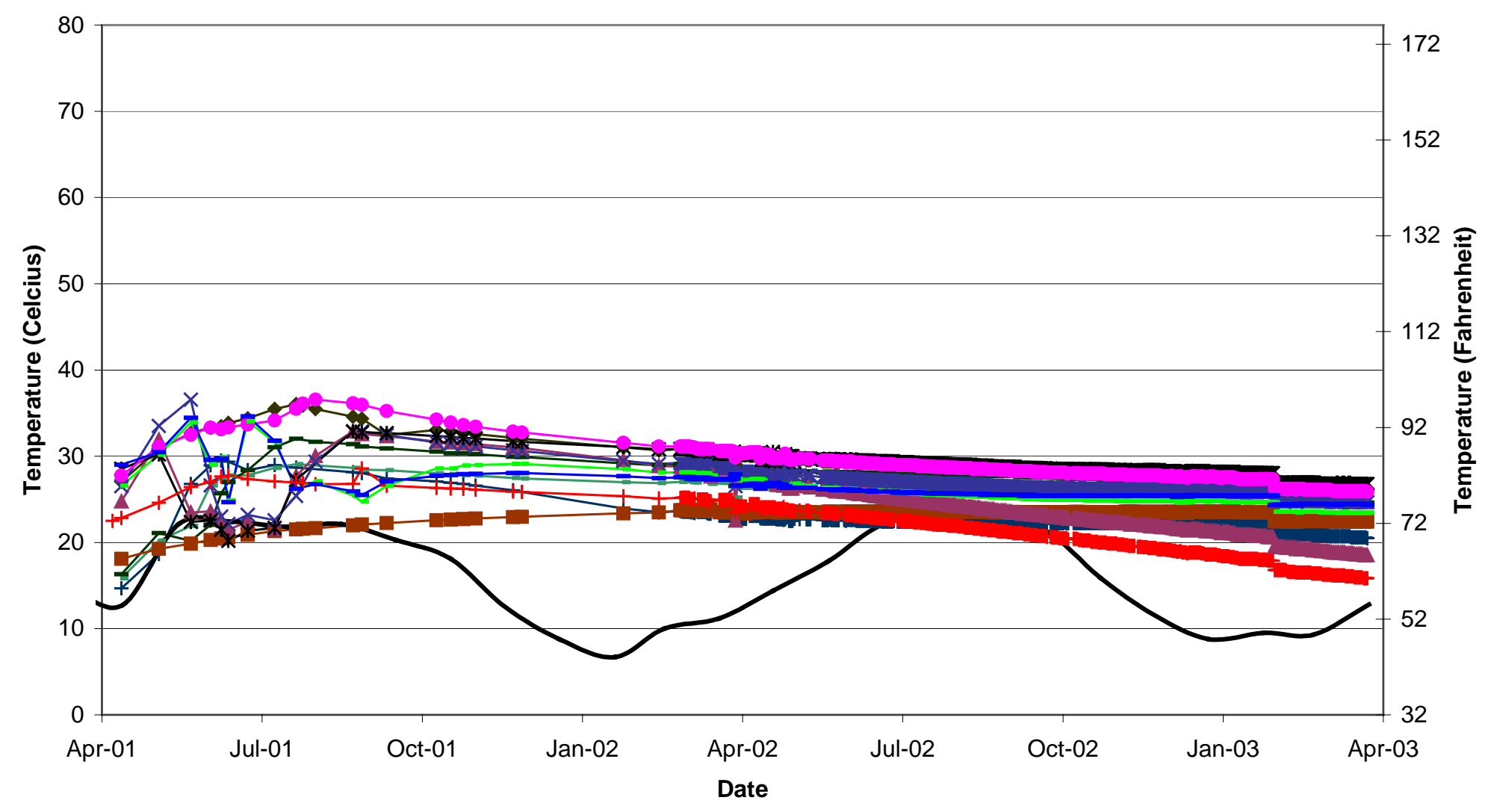

\begin{tabular}{lll|}
\hline$\rightarrow 0-21$ & $=0-22$ & $-0-23$ \\
$\rightarrow-0-24$ & $\rightarrow-0-25$ & $\square-0-26$ \\
$\rightarrow 0-27$ & $\because-0-28$ & $\square-29$ \\
$\longrightarrow 0-30$ & $-0-31$ & $-0-32$ \\
\hline Mean Ambient Air Temperature & & \\
\hline
\end{tabular}


Figure 6-6. Module D Base Liner PVC Moisture Readings (Northwest and Southwest Quadrants)

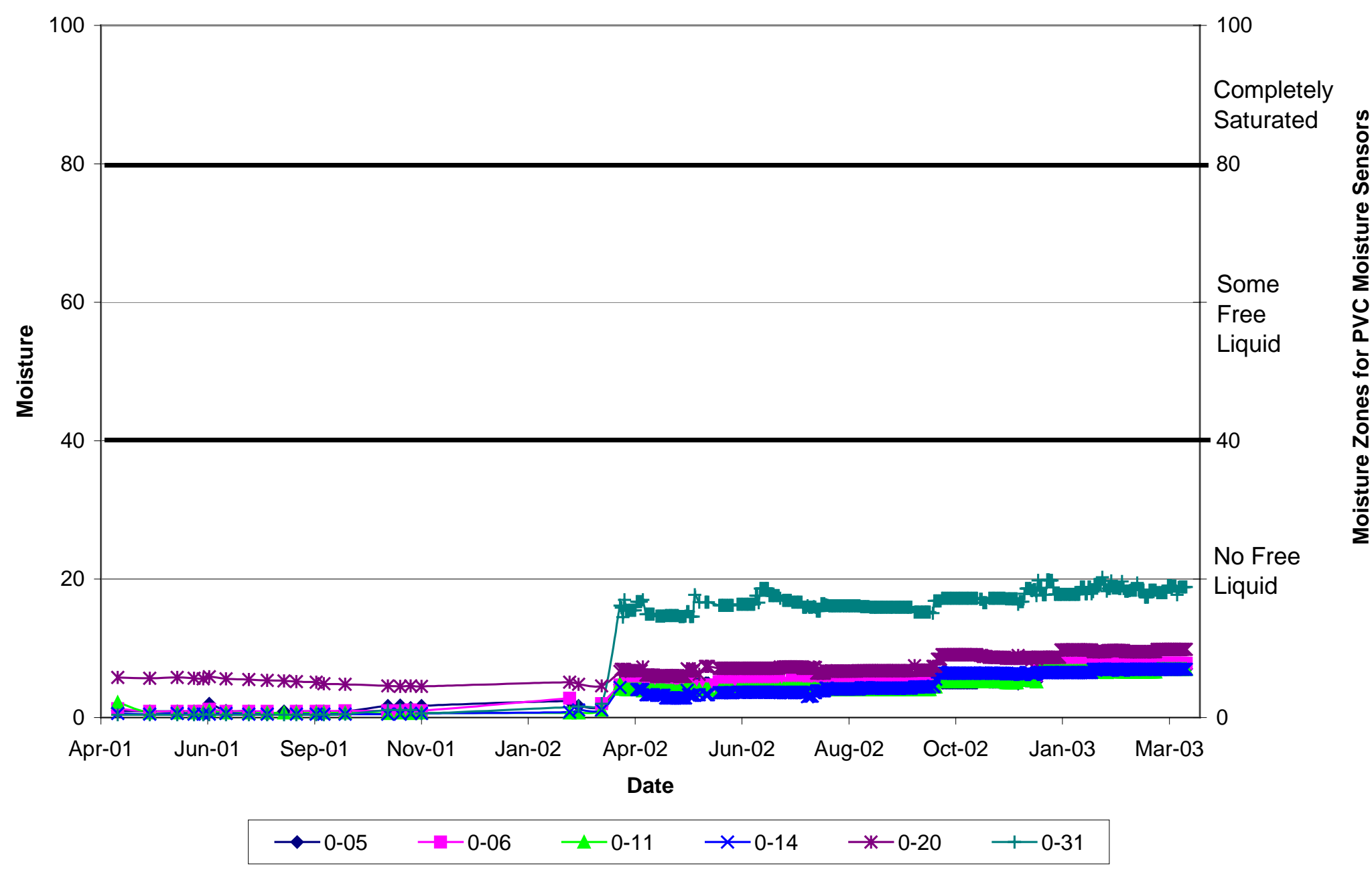


Figure 6-7. Module D Base Liner PVC Moisture Readings (Northeast Quadrant)

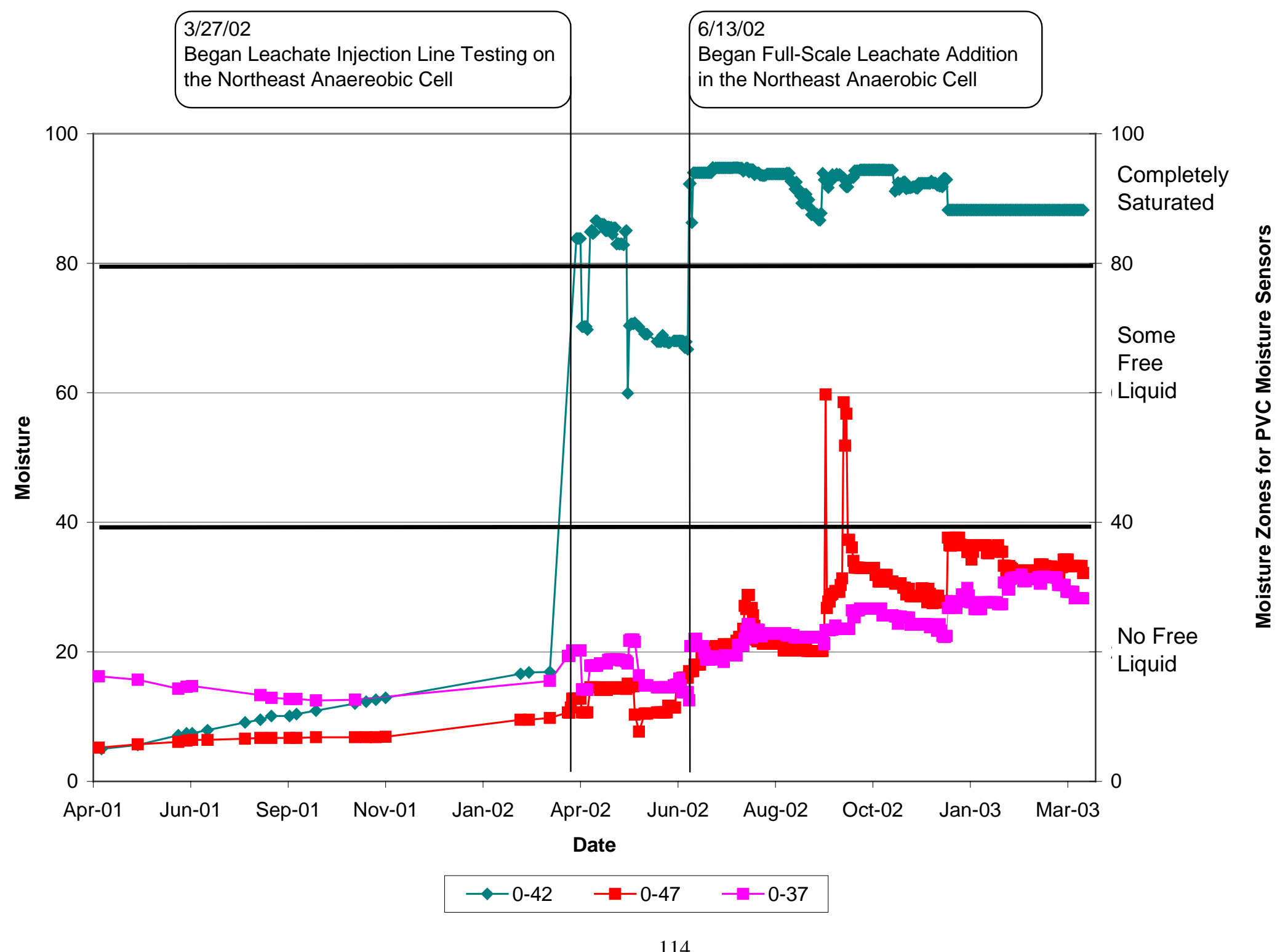


Figure 6-8. Module D Base Liner PVC Moisture Readings (Southeast Quadrant)

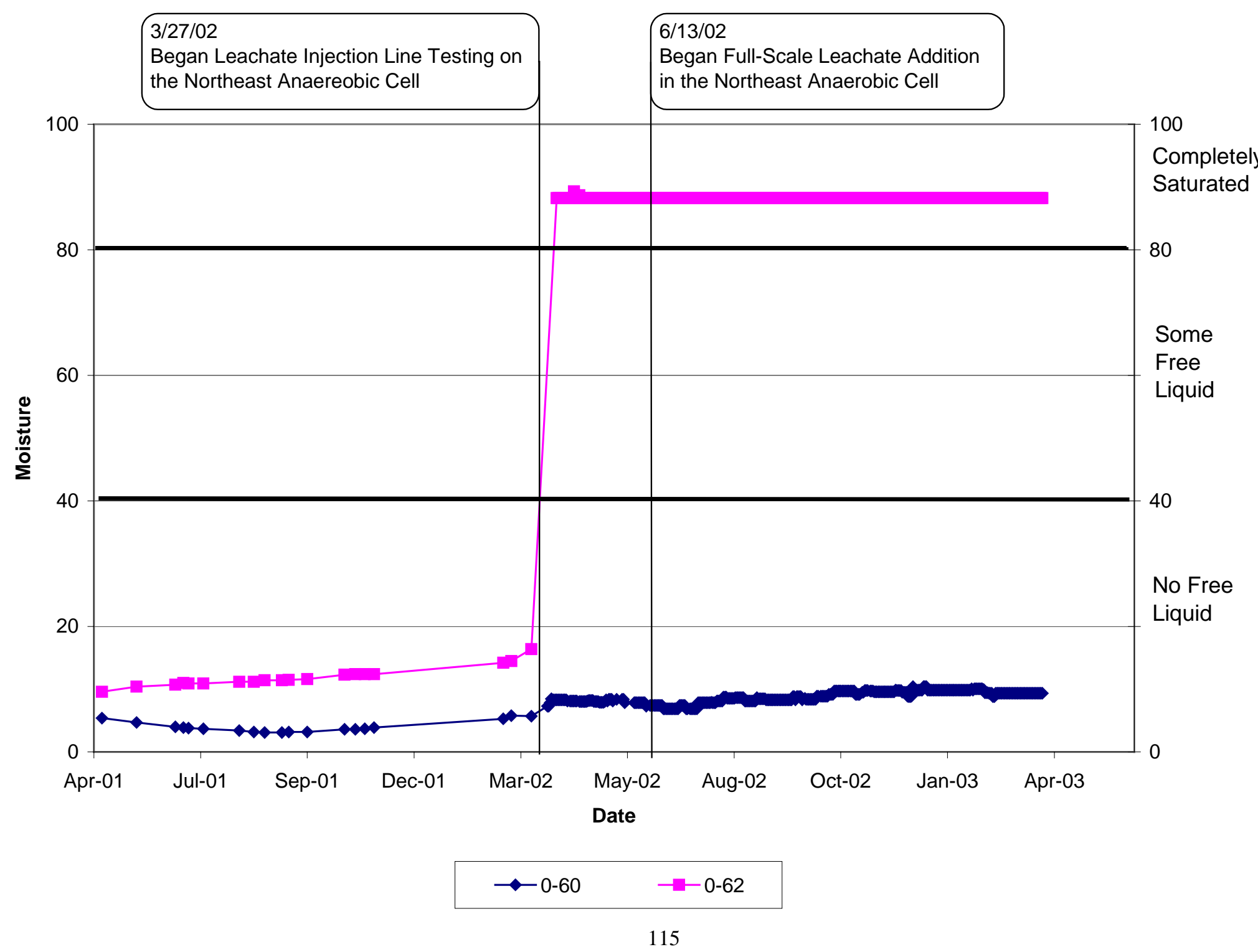


Figure 6-10. Module D Base Liner Pressure Transducers and Adjacent Tubes

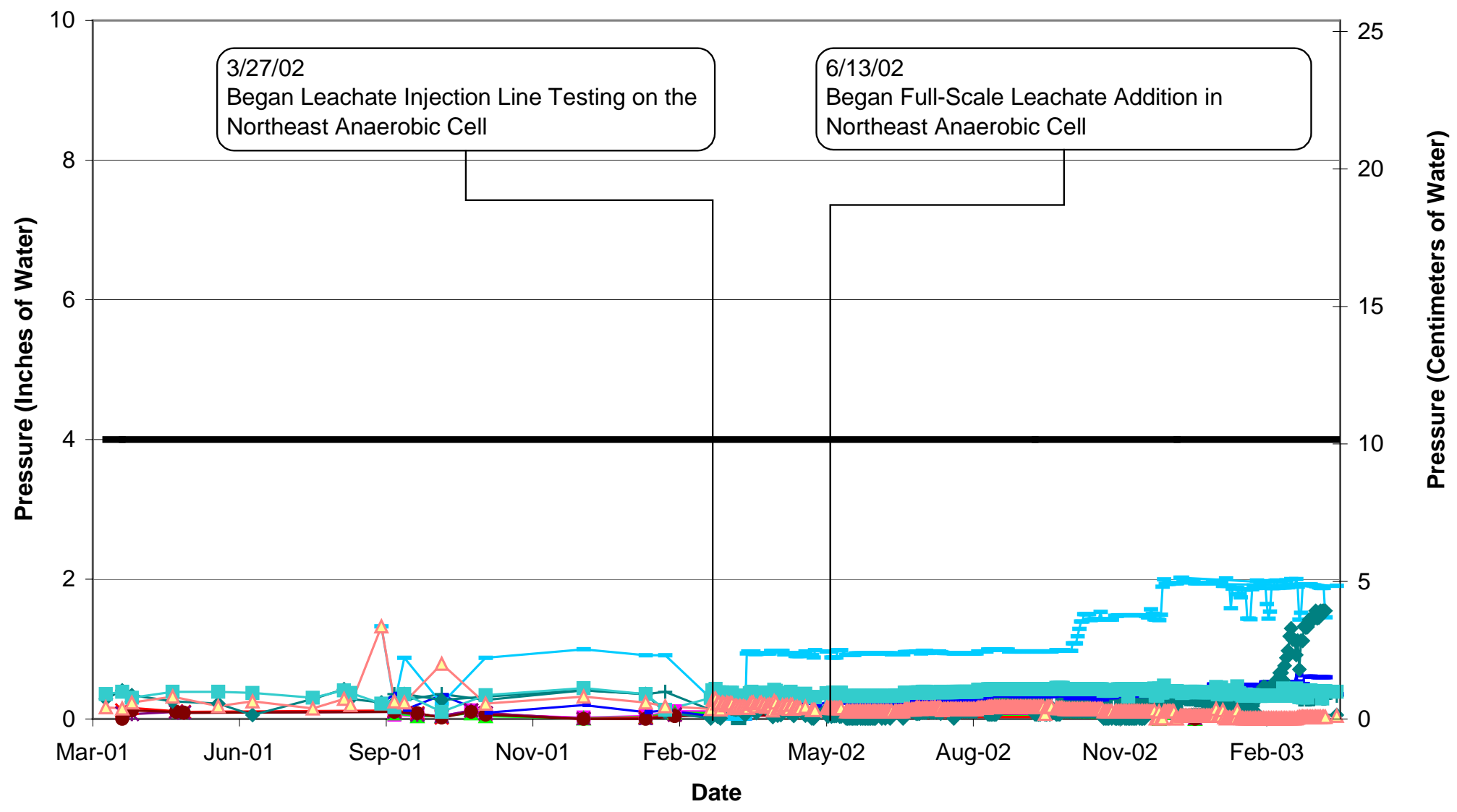

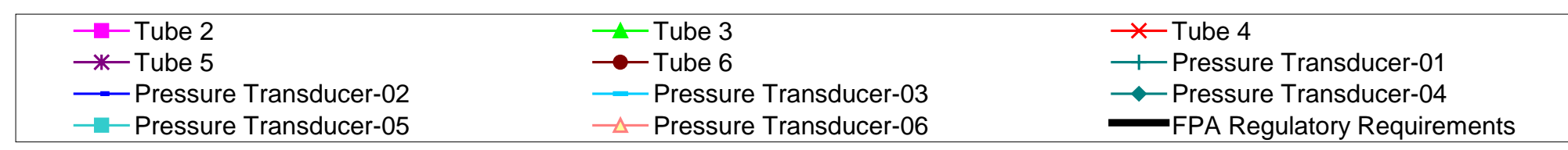


APPENDIX D - LANDFILL GAS LABORATORY CHEMISTRY 
Table 3-8. Analytical Results for Landfill Gas Sampled from Module D

\begin{tabular}{|c|c|c|c|c|c|c|c|c|c|}
\hline \multirow[b]{2}{*}{ GAS ANALYSIS PARAMETERS } & \multirow[b]{2}{*}{ DATE: } & \multicolumn{3}{|c|}{ Northeast Anaerobic Cell } & \multirow[b]{2}{*}{$12 / 5 / 2002$} & \multirow[b]{2}{*}{$3 / 18 / 2003$} & \multicolumn{2}{|c|}{ West-Side Anaerobic Cell } & \multirow{2}{*}{\begin{tabular}{|c|} 
Aerobic Cell \\
$3 / 18 / 2003$ \\
\end{tabular}} \\
\hline & & $3 / 8 / 2002$ & $5 / 29 / 2002$ & $8 / 29 / 2002$ & & & $5 / 29 / 2002$ & $3 / 18 / 2003$ & \\
\hline Method CFR60 EPA 25C Mod: & Units & & & & & & & & \\
\hline Methane & $\mathrm{ppm}$ & 280,000 & 280,000 & 460,000 & 400,000 & 390,000 & 230,000 & 180,000 & 100,000 \\
\hline Total Non-Methane Hydocarbons as Methane & $\mathrm{ppm}$ & 10,000 & 9,500 & 6,200 & 3,000 & 1,600 & 5,100 & 2,200 & 7,700 \\
\hline \multicolumn{10}{|l|}{ Method CFR60A EPA 15/16: } \\
\hline Dimethyl Sulfide & ppm & 18 & 12 & 11 & 4.5 & 2.7 & 5.2 & 5 & 10 \\
\hline Hydrogen Sulfide & $\mathrm{ppm}$ & ND & ND & 1.8 & 220 & 160 & ND & 66 & ND \\
\hline Carbonyl Sulfide & $\mathrm{ppm}$ & $\mathrm{ND}$ & ND & ND & 0.47 & 0.43 & $\mathrm{ND}$ & 0.91 & $\mathrm{ND}$ \\
\hline Methyl Mercaptan & $\mathrm{ppm}$ & ND & ND & 0.38 & 0.87 & 0.44 & ND & 1.3 & 1 \\
\hline Ethyl Mercaptan & $\mathrm{ppm}$ & ND & ND & ND & ND & ND & ND & ND & $\mathrm{ND}$ \\
\hline Carbon Disulfide & ppm & 0.64 & 0.54 & $\mathrm{ND}$ & ND & $\mathrm{ND}$ & $\mathrm{ND}$ & 0.89 & ND \\
\hline Dimethyl Disulfide & $\mathrm{ppm}$ & 0.52 & ND & $\mathrm{ND}$ & $\mathrm{ND}$ & $\mathrm{ND}$ & $\mathrm{ND}$ & ND & 0.84 \\
\hline \multicolumn{10}{|l|}{ Method CFR60 EPA 3C: } \\
\hline Carbon Dioxide & $\%$ & 41 & 41 & 43 & 37 & 40 & 68 & 19 & 24 \\
\hline Carbon Monoxide & $\%$ & ND & ND & ND & ND & $\mathrm{ND}$ & ND & ND & $\mathrm{ND}$ \\
\hline Methane & $\%$ & 28 & 28 & 46 & 40 & 39 & 23 & 18 & 10 \\
\hline Nitrogen & $\%$ & 26 & 27 & 6.9 & 20 & 15 & 11 & 49 & 62 \\
\hline Oxygen & $\%$ & 0.83 & 0.21 & 0.26 & 1.9 & 1.5 & ND & 11 & 1.9 \\
\hline \multicolumn{10}{|l|}{ Method EPA-2 TO -15: } \\
\hline Dichlorodifluormethane & $\mathrm{ppb}$ & 7,900 & 6,400 & 1,400 & 1,300 & 1,200 & 17,000 & 3,800 & 1,400 \\
\hline Chloromethane & $\mathrm{ppb}$ & ND & $\mathrm{ND}$ & ND & ND & $\mathrm{ND}$ & ND & ND & ND \\
\hline 1,2-Dichloro-1,1,2,2-tetrafluoroethane & $\mathrm{ppb}$ & ND & 400 & 320 & 110 & 85 & 1,100 & 340 & ND \\
\hline Vinyl Chloride & $\mathrm{ppb}$ & $\mathrm{ND}$ & 950 & 3,600 & 4,000 & 1,200 & 1,200 & 170 & ND \\
\hline Bromomethane & $\mathrm{ppb}$ & ND & ND & ND & ND & ND & $\mathrm{ND}$ & ND & ND \\
\hline Chloroethane & $\mathrm{ppb}$ & 1,100 & 820 & 550 & 360 & 170 & 780 & 320 & ND \\
\hline Trichlorofluoromethane & $\mathrm{ppb}$ & 620 & 430 & 280 & 130 & 92 & 7,900 & 370 & ND \\
\hline 1,1-Dichlorethene & $\mathrm{ppb}$ & ND & ND & ND & ND & ND & ND & 440 & 580 \\
\hline Carbon Disulfide & $\mathrm{ppb}$ & ND & ND & ND & ND & ND & ND & ND & ND \\
\hline 1,1,2-Trichloro-1,2,2-trifluoroethane & $\mathrm{ppb}$ & ND & ND & ND & ND & ND & 960 & ND & ND \\
\hline
\end{tabular}




\begin{tabular}{|c|c|c|c|c|c|c|c|c|c|}
\hline Acetone & $\mathrm{ppb}$ & 54,000 & 28,000 & 22,000 & 10,000 & 4,300 & 13,000 & 16,000 & 50,000 \\
\hline Methylene Chloride & $\mathrm{ppb}$ & 14,000 & 8,200 & 3,900 & 1,200 & 300 & 4,800 & 3,500 & 1,700 \\
\hline trans-1,2-Dichloroethene & $\mathrm{ppb}$ & ND & ND & ND & ND & ND & ND & ND & ND \\
\hline 1,1-Dichloroethane & $\mathrm{ppb}$ & 1,600 & 1,000 & 850 & 340 & 130 & 880 & 440 & $\mathrm{ND}$ \\
\hline Vinyl Acetate & $\mathrm{ppb}$ & ND & ND & $\mathrm{ND}$ & ND & $\mathrm{ND}$ & $\mathrm{ND}$ & $\mathrm{ND}$ & ND \\
\hline cis-1,2-Dichloroethene & $\mathrm{ppb}$ & ND & 240 & 670 & 760 & 520 & $\mathrm{ND}$ & 290 & ND \\
\hline 2-Butanone (MEK) & $\mathrm{ppb}$ & 38,000 & 28,000 & 29,000 & 9,500 & 3,800 & 6,000 & 23,000 & 28,000 \\
\hline Chloroform & $\mathrm{ppb}$ & ND & ND & ND & ND & ND & ND & ND & ND \\
\hline 1,1,1-Trichloroethane & $\mathrm{ppb}$ & $\mathrm{ND}$ & $\mathrm{ND}$ & ND & ND & 42 & 680 & $\mathrm{ND}$ & ND \\
\hline Carbon Tetrachloride & $\mathrm{ppb}$ & ND & ND & ND & ND & ND & ND & ND & ND \\
\hline Benzene & $\mathrm{ppb}$ & 1,700 & 1,800 & 1,500 & 960 & 380 & 490 & 980 & 1,300 \\
\hline 1,2-Dichloroethane & $\mathrm{ppb}$ & ND & ND & ND & ND & ND & 120 & ND & 220 \\
\hline Trichloroethene & $\mathrm{ppb}$ & 1,700 & 1,300 & 1,200 & 620 & 260 & 220 & 860 & 620 \\
\hline 1,2-Dichloropropane & $\mathrm{ppb}$ & ND & ND & ND & ND & ND & ND & ND & ND \\
\hline Bromoodichloromethane & $\mathrm{ppb}$ & $\mathrm{ND}$ & ND & ND & ND & ND & ND & $\mathrm{ND}$ & ND \\
\hline cis-1,3-Dichloropropene & $\mathrm{ppb}$ & ND & ND & ND & ND & ND & $\mathrm{ND}$ & $\mathrm{ND}$ & ND \\
\hline 4-Methyl-2-Pentanone (MIBK) & $\mathrm{ppb}$ & 10,000 & 9,700 & 8,100 & 2,500 & 760 & 5,400 & 4,500 & 14,000 \\
\hline Toluene & $\mathrm{ppb}$ & 31,000 & 26,000 & 25,000 & 19,000 & 8,400 & 3,400 & 21,000 & 20,000 \\
\hline trans-1,3-Dichloropropene & $\mathrm{ppb}$ & ND & ND & ND & ND & ND & ND & ND & ND \\
\hline 1,1,2-Trichloroethane & $\mathrm{ppb}$ & ND & $\mathrm{ND}$ & ND & ND & ND & ND & ND & $\mathrm{ND}$ \\
\hline Tetrachloroethene & $\mathrm{ppb}$ & 2,300 & 2,200 & 1,600 & 1,000 & 480 & 350 & 1,100 & 1,500 \\
\hline 2-Hexanone & $\mathrm{ppb}$ & $\mathrm{ND}$ & $\mathrm{ND}$ & $\mathrm{ND}$ & $\mathrm{ND}$ & ND & $\mathrm{ND}$ & $\mathrm{ND}$ & ND \\
\hline Dibromochloromethane & $\mathrm{ppb}$ & $\mathrm{ND}$ & ND & ND & ND & ND & ND & ND & ND \\
\hline 1,2-Dibromoethane (EDB) & $\mathrm{ppb}$ & ND & ND & ND & ND & ND & ND & ND & ND \\
\hline Chlorobenzene & $\mathrm{ppb}$ & ND & ND & ND & ND & ND & ND & ND & ND \\
\hline Ethylbenzene & $\mathrm{ppb}$ & 2,800 & 3,200 & 3,000 & 3,100 & 1,800 & 170 & 5,100 & 2,300 \\
\hline Total Xylenes & $\mathrm{ppb}$ & 9,400 & 11,000 & 9,700 & 9,700 & 5,200 & 480 & 14,000 & 6,500 \\
\hline Styrene & $\mathrm{ppb}$ & 700 & 930 & 950 & 980 & 350 & ND & 890 & 310 \\
\hline Bromoform & $\mathrm{ppb}$ & ND & ND & ND & $\mathrm{ND}$ & ND & ND & ND & $\mathrm{ND}$ \\
\hline 1,1,2,2-Tetrachloroethane & $\mathrm{ppb}$ & ND & ND & ND & ND & ND & ND & ND & ND \\
\hline Benzyl Chloride & $\mathrm{ppb}$ & $\mathrm{ND}$ & ND & ND & ND & ND & ND & $\mathrm{ND}$ & $\mathrm{ND}$ \\
\hline 4-Ethyltoluene & $\mathrm{ppb}$ & ND & 930 & 710 & 980 & 470 & ND & 590 & 500 \\
\hline
\end{tabular}




\begin{tabular}{|c|c|c|c|c|c|c|c|c|c|}
\hline 1,3,5-Trimethylbenzene & $\mathrm{ppb}$ & ND & 290 & 260 & 390 & 170 & ND & 230 & ND \\
\hline 1,2,4-Trimethylbenzene & $\mathrm{ppb}$ & ND & 760 & 640 & 840 & 380 & ND & 370 & 370 \\
\hline 1,3-Dichlorobenzene & $\mathrm{ppb}$ & ND & ND & ND & ND & ND & ND & ND & ND \\
\hline 1,4-Dichlorobenzene & $\mathrm{ppb}$ & ND & 270 & 190 & 280 & 66 & ND & ND & ND \\
\hline 1,2-Dichlorobenzene & $\mathrm{ppb}$ & ND & ND & ND & ND & ND & ND & ND & ND \\
\hline 1,2,4-Trichlorobenzene & $\mathrm{ppb}$ & ND & ND & $\mathrm{ND}$ & ND & $\mathrm{ND}$ & ND & $\mathrm{ND}$ & ND \\
\hline Hexachlorobutadiene & $\mathrm{ppb}$ & ND & ND & ND & ND & ND & ND & $\mathrm{ND}$ & ND \\
\hline
\end{tabular}

\section{Footnotes:}

$\mathrm{ND}=$ Not Detected 
APPENDIX E - LEACHATE LABORATORY CHEMISTRY 
Table 3-9. Field Chemistry and Analytical Results for Leachate Sampled from the Northeast Anaerobic Cell

\begin{tabular}{|c|c|c|c|c|c|c|c|c|c|c|}
\hline PARAMETER & Date: & $2 / 14 / 2002$ & $3 / 27 / 2002$ & $5 / 14 / 2002$ & $6 / 20 / 2002$ & $7 / 23 / 2002$ & $8 / 13 / 2002$ & $9 / 26 / 2002$ & $10 / 17 / 2002$ & $2 / 26 / 2003$ \\
\hline \multicolumn{11}{|l|}{ Field Parameters: } \\
\hline $\mathrm{pH}$ & & 7.13 & 7.55 & 7.40 & 7.60 & 7.44 & 7.48 & 7.47 & 7.35 & 8.16 \\
\hline Electrical Conductivity & $\mu \mathrm{S}$ & 6583 & 6173 & 6095 & 4054 & 11510 & 15860 & 12440 & 10230 & 9351 \\
\hline Oxidation Reduction Potential & $\mathrm{mV}$ & -119 & -12 & 80 & 94 & -7 & 43 & -35 & -25 & 160 \\
\hline Temperature & $\mathrm{C}$ & 19.9 & 21.5 & 25.9 & 26.5 & 30.5 & 30.5 & 28.4 & 26.0 & 23.5 \\
\hline Dissolved Oxygen & $\mathrm{mg} / \mathrm{L}$ & 0.65 & 2.13 & 1.4 & 2.04 & 0.33 & 1.31 & 3.66 & 2.96 & 6 \\
\hline Total Dissolved Solids & ppm & 5244 & 4860 & 4059 & 3062 & 9740 & 14050 & 10770 & 8640 & 7850 \\
\hline \multicolumn{11}{|l|}{ General Chemistry: } \\
\hline Bicarbonate Alkalinity & $\mathrm{mg} / \mathrm{L}$ & 1740 & 1550 & 1760 & 1110 & 3740 & 5150 & 3960 & 4010 & 2680 \\
\hline Carbonate Alkalinity & $\mathrm{mg} / \mathrm{L}$ & $<5.0$ & $<5.0$ & $<5.0$ & $<5.0$ & $<5.0$ & $<5.0$ & $<5.0$ & $<5.0$ & $<5.0$ \\
\hline Total Alkalinity as $\mathrm{CO}_{3}$ & $\mathrm{mg} / \mathrm{L}$ & 1740 & 1550 & 1760 & 1110 & 3740 & 5150 & 3960 & 4010 & 2680 \\
\hline BOD & $\mathrm{mg} \mathrm{O} / \mathrm{L}$ & 20 & 34 & 19 & 10 & 200 & 490 & 1400 & 3000 & 44 \\
\hline Chemical Oxygen Demand & $\mathrm{mg} \mathrm{O} / \mathrm{L}$ & 633 & 488 & 791 & 196 & 1620 & 2820 & 2830 & 1810 & 120 \\
\hline Chloride & \begin{tabular}{|l|}
$\mathrm{mg} / \mathrm{L}$ \\
\end{tabular} & 1070 & 1100 & 1030 & 617 & 1950 & 2830 & 1870 & 1380 & 1470 \\
\hline Hydroxide & $\mathrm{mg} / \mathrm{L}$ & $<5.0$ & $<5.0$ & $<5.0$ & $<5.0$ & $<5.0$ & $<5.0$ & $<5.0$ & $<5.0$ & $<5.0$ \\
\hline Ammonia as $\mathrm{N}$ & $\mathrm{mg} / \mathrm{L}$ & 30 & 24.4 & 26.3 & 13.5 & 131 & 264 & 255 & 289 & 132 \\
\hline Nitrate-Nitrite as $\mathrm{N}$ & $\mathrm{mg} / \mathrm{L}$ & $<0.03$ & 0.43 & $<1.5$ & $<0.015$ & 0.061 & $0.22(\mathrm{tr})$ & 1.4 & $<0.009$ & 17.3 \\
\hline Total Kjeldahl Nitrogen & $\mathrm{mg} / \mathrm{L}$ & 53.1 & 71 & 40 & 21.8 & 201 & 354 & 326 & 358 & 222 \\
\hline Sulfate & $\mathrm{mg} / \mathrm{L}$ & 322 & 210 & 94.3(tr) & 256 & 5.3 & $8.2(\mathrm{tr})$ & 155 & 7 & 315 \\
\hline Total Dissolved Solids @ 180 C & $\mathrm{mg} / \mathrm{L}$ & 4440 & 3960 & 3700 & 2500 & 7800 & 9860 & 8000 & 6680 & 5720 \\
\hline Total (Non-Volatile) Organic Carbon & $\mathrm{mg} / \mathrm{L}$ & 202 & 147 & 123 & 68.8 & 544 & 713 & 943 & 588 & 325 \\
\hline Total Phosphorus & $\mathrm{mg} / \mathrm{L}$ & 1.9 & 1.3 & 1.1 & 1.6 & 1.9 & 2.7 & 3.7 & 3.4 & 1.8 \\
\hline Total Sulfide & $\mathrm{mg} / \mathrm{L}$ & 1.3 & 0.18 & 1.3 & 0.74 & 1.2 & 2.5 & 1.1 & 1.4 & 0.034 (tr) \\
\hline \multicolumn{11}{|l|}{ Metals: } \\
\hline Dissolved Aluminum & $\mathrm{mg} / \mathrm{L}$ & $0.14(\mathrm{tr})$ & $<0.043$ & $0.10(\operatorname{tr})$ & $<0.043$ & $0.097(\mathrm{tr})$ & $0.11(\operatorname{tr})$ & $0.058(\mathrm{tr})$ & $0.096(\operatorname{tr})$ & 0.063 (tr) \\
\hline Dissolved Antimony & $\mathrm{mg} / \mathrm{L}$ & 0.0022 & $0.0015(\mathrm{tr})$ & $0.0012(\mathrm{tr})$ & $0.0008(\mathrm{tr})$ & 0.012 & $<0.031$ & 0.0089 & 0.0072 & 0.0072 \\
\hline Dissolved Arsenic & $\mathrm{mg} / \mathrm{L}$ & 0.029 & 0.026 & 0.028 & 0.037 & 0.054 & 0.062 & 0.058 & 0.062 & 0.043 \\
\hline Dissolved Barium & $\mathrm{mg} / \mathrm{L}$ & 0.84 & 0.56 & 0.92 & 0.39 & 1.6 & 1.6 & 2.5 & 1.7 & 0.88 \\
\hline Dissolved Beryllium & $\mathrm{mg} / \mathrm{L}$ & $<0.000078$ & $<0.000078$ & $<0.00078$ & $<0.000078$ & $<0.000078$ & $<0.00009$ & $<0.000078$ & $<0.000078$ & $<0.000078$ \\
\hline Dissolved Boron & $\mathrm{mg} / \mathrm{L}$ & 7.9 & 7.1 & 7.4 & NA & 12.8 & 20.1 & 15.7 & 11.6 & 11.1 \\
\hline
\end{tabular}




\begin{tabular}{|c|c|c|c|c|c|c|c|c|c|c|}
\hline Dissolved Cadmium & $\mathrm{mg} / \mathrm{L}$ & $<0.000074$ & $<0.000074$ & $<0.000074$ & $<0.000074$ & $<0.000074$ & $<0.0031$ & $<0.000074$ & $<0.000074$ & $0.00018(\mathrm{tr})$ \\
\hline Dissolvd Calcium & $\mathrm{mg} / \mathrm{L}$ & 183 & 137 & 158 & NA & 175 & 92 & 174 & 221 & 114 \\
\hline Dissolved Chromium & $\mathrm{mg} / \mathrm{L}$ & 0.036 & 0.024 & 0.025 & 0.0099 & 0.086 & 0.075 & 0.074 & 0.073 & 0.071 \\
\hline Dissolved Cobalt & $\mathrm{mg} / \mathrm{L}$ & 0.007 & 0.0058 & 0.0049 & 0.0034 & 0.011 & $0.014(\operatorname{tr})$ & 0.018 & 0.016 & 0.037 \\
\hline Dissolved Copper & $\mathrm{mg} / \mathrm{L}$ & 0.0054 & 0.004 & 0.002 & 0.0024 & $0.0052 *$ & $0.0043(\mathrm{tr})$ & $0.0044^{*}$ & 0.0044 & $0.03 *$ \\
\hline Dissolved Iron & $\mathrm{mg} / \mathrm{L}$ & 1.1 & 0.44 & 0.39 & 0.19 & $2.9 *$ & 1.8 & 3.9 & 4 & 2.5 \\
\hline Dissolved Lead & $\mathrm{mg} / \mathrm{L}$ & $0.00046(\mathrm{tr})$ & $0.00016(\mathrm{tr})$ & $0.00020(\mathrm{tr})$ & $<0.000066$ & 0.001 & 0.0016 & 0.0011 & 0.00078 (tr) & 0.0014 \\
\hline Dissolved Magnesium & $\mathrm{mg} / \mathrm{L}$ & \begin{tabular}{|l|}
323 \\
\end{tabular} & 248 & 262 & NA & 535 & 655 & 480 & 437 & 359 \\
\hline Dissolved Manganese & $\mathrm{mg} / \mathrm{L}$ & 4.1 & 3.2 & 4.5 & 2.9 & 2 & 0.33 & 3 & 0.94 & 0.68 \\
\hline Dissolved Mercury & $\mathrm{mg} / \mathrm{L}$ & $<0.000049$ & $<0.000049$ & $<0.000049$ & $<0.000049$ & $<0.000049$ & $0.000081(\mathrm{tr}) *$ & $<0.000049$ & $<0.000049$ & $<0.000064$ \\
\hline Dissolved Molybdenum & $\mathrm{mg} / \mathrm{L}$ & $0.012(\mathrm{tr})$ & $<0.0046$ & $<0.0046$ & $0.0048(\mathrm{tr})$ & $0.0048(\mathrm{tr})$ & $<0.0046$ & $<0.0046$ & $<0.0046$ & $0.013(\mathrm{tr})$ \\
\hline Dissolved Nickel & $\mathrm{mg} / \mathrm{L}$ & 0.13 & 0.14 & 0.13 & 0.08 & 0.26 & 0.3 & 0.23 & 0.2 & 0.38 \\
\hline Dissolved Potassium & $\mathrm{mg} / \mathrm{L}$ & 152 & 124 & 133 & $\mathrm{NA}$ & 215 & 336 & 319 & 348 & 371 \\
\hline Dissolved Phosphorus & $\mathrm{mg} / \mathrm{L}$ & 1.9 & 0.96 & 1.9 & $\mathrm{NA}$ & 1.6 & 2 & 3.6 & 2.6 & 1.8 \\
\hline Dissolved Selenium & $\mathrm{mg} / \mathrm{L}$ & $<0.0017$ & $<0.0017$ & $<0.0017$ & $<0.0017$ & $<0.0017$ & $<0.0017$ & 0.0077 & $<0.0017$ & 0.002 \\
\hline Dissolved Silver & $\mathrm{mg} / \mathrm{L}$ & $\begin{array}{c}0.000083 \\
(\mathrm{tr})\end{array}$ & $\begin{array}{c}0.000031(\mathrm{tr} \\
)\end{array}$ & $<0.00003$ & $<0.00003$ & $0.0002(\mathrm{tr})$ & $<0.0032$ & $0.0001(\mathrm{tr})$ & $\begin{array}{c}0.000061 \\
(\mathrm{tr})\end{array}$ & $\begin{array}{c}0.000084 \\
(\mathrm{tr})\end{array}$ \\
\hline Dissolved Sodium & $\mathrm{mg} / \mathrm{L}$ & 875 & 774 & 759 & NA & 1370 & 2340 & 1820 & 1330 & $1440 *$ \\
\hline Dissolved Thallium & $\mathrm{mg} / \mathrm{L}$ & $<0.00034$ & $<0.00034$ & $<0.00034$ & $<0.00034$ & $<0.00034$ & $<0.0034$ & $<0.00034$ & $<0.00034$ & $<0.00034$ \\
\hline Dissolved Tin & $\mathrm{mg} / \mathrm{L}$ & $<0.022$ & $<0.022$ & $<0.022$ & $<0.022$ & $<0.022$ & $<0.022$ & $<0.022$ & $<0.022$ & $0.0062(\mathrm{tr})$ \\
\hline Dissolved Vanadium & $\mathrm{mg} / \mathrm{L}$ & 0.059 & $0.03(\mathrm{tr})$ & $0.031(\mathrm{tr})$ & $0.013(\mathrm{tr})$ & 0.21 & 0.1 & 0.071 & 0.054 & 0.061 \\
\hline Dissolved Zinc & $\mathrm{mg} / \mathrm{L}$ & 0.032 & 0.034 & 0.035 & 0.015 & $0.13(\operatorname{tr})$ & 0.13 & 0.17 & 0.13 & 0.15 \\
\hline \multicolumn{11}{|l|}{ Volatile Organic Compounds: } \\
\hline Acetone & $\mu \mathrm{g} / \mathrm{L}$ & 16 & 10 & 6.4 & 6.9 & $170^{*}$ & $1500(\mathrm{tr})$ & 2300 & 650 & 49 \\
\hline Acrylonitrile & $\mu \mathrm{g} / \mathrm{L}$ & $<10$ & $<10$ & $<10$ & $<10$ & $<50$ & $<100$ & $<1000$ & $<200$ & $<20$ \\
\hline Benzene & $\mu \mathrm{g} / \mathrm{L}$ & $<0.13$ & $0.28(\mathrm{tr})^{*}$ & $0.22(\mathrm{tr})$ & $<0.13$ & $<0.65$ & $<1.3$ & $<13$ & $<2.6$ & $0.36(\mathrm{tr})$ \\
\hline Bromobenzene & $\mu \mathrm{g} / \mathrm{L}$ & $<0.18$ & $<0.18$ & $<0.18$ & $<0.18$ & $<0.90$ & NA & $<18$ & $<3.6$ & $<0.36$ \\
\hline Bromochloromethane & $\mu \mathrm{g} / \mathrm{L}$ & $<0.31$ & $<0.31$ & $<0.31$ & $<0.31$ & $<1.6$ & $<3.1$ & $<31$ & $<6.2$ & $<0.62$ \\
\hline Bromodichloromethane & $\mu \mathrm{g} / \mathrm{L}$ & $<0.14$ & $<0.14$ & $<0.14$ & $<0.14$ & $<0.70$ & $<1.4$ & $<14$ & $<2.8$ & $<0.28$ \\
\hline Bromoform & $\mu \mathrm{g} / \mathrm{L}$ & $<0.10$ & $<0.10$ & $<0.10$ & $<0.10$ & $<0.50$ & $<1.0$ & $<10$ & $<2.0$ & $<0.20$ \\
\hline Bromomethane (Methly bromide) & $\mu \mathrm{g} / \mathrm{L}$ & $<0.08$ & $<0.08$ & $0.68(\mathrm{tr})$ & $<0.08$ & $6.2 *$ & $<0.80$ & $37(\mathrm{tr})^{*}$ & $<1.6$ & $0.96(\mathrm{tr})$ \\
\hline 2-Butanone (MEK) & $\mu \mathrm{g} / \mathrm{L}$ & $<1.0$ & $<1.0$ & $<1.0$ & $1.1(\mathrm{tr})$ & 240 & 2200 & 4300 & 1400 & $3.8(\mathrm{tr})$ \\
\hline n-Butylbenzene & $\mu \mathrm{g} / \mathrm{L}$ & $<0.12$ & $<0.12$ & $<0.12$ & $<0.12$ & $<0.60$ & NA & $<12$ & $<2.4$ & $<0.24$ \\
\hline sec-Butylbenzene & $\mu \mathrm{g} / \mathrm{L}$ & $<0.12$ & $<0.12$ & $<0.12$ & $<0.12$ & $<0.60$ & NA & $<12$ & $<2.4$ & $<0.24$ \\
\hline
\end{tabular}




\begin{tabular}{|c|c|c|c|c|c|c|c|c|c|c|}
\hline tert-Butylbenzene & $\mu \mathrm{g} / \mathrm{L}$ & $<0.14$ & $<0.14$ & $<0.14$ & $<0.14$ & $<0.70$ & NA & $<14$ & $<2.8$ & $<0.28$ \\
\hline Carbon Disulfide & $\mu \mathrm{g} / \mathrm{L}$ & $<1.0$ & $<1.0$ & $1.1(\mathrm{tr})$ & $<1.0$ & $<5.0$ & $<10$ & $<100$ & $<20$ & $<2.0$ \\
\hline Carbon Tetrachloride & $\mu \mathrm{g} / \mathrm{L}$ & $<0.15$ & $<0.15$ & $<0.15$ & $<0.15$ & $<0.75$ & $<1.5$ & $<15$ & $<3.0$ & $<0.30$ \\
\hline Chlorobenzene & $\mu \mathrm{g} / \mathrm{L}$ & $<0.12$ & $<0.12$ & $<0.12$ & $<0.12$ & $<0.60$ & $<1.2$ & $<12$ & $<2.4$ & $0.67(\operatorname{tr})$ \\
\hline Chloroethane & $\mu \mathrm{g} / \mathrm{L}$ & $<0.34$ & $<0.34$ & $<0.34$ & $<0.34$ & $<1.7$ & $<3.4$ & $<34$ & $<6.8$ & $<0.68$ \\
\hline Chloroform & $\mu \mathrm{g} / \mathrm{L}$ & $<0.12$ & $<0.12$ & $<0.12$ & $<0.12$ & $<0.60$ & $<1.2$ & $<12$ & $7.5(\operatorname{tr})$ & $<0.24$ \\
\hline Chloromethane (Methyl chloride) & $\mu \mathrm{g} / \mathrm{L}$ & $<0.25$ & $<0.25$ & $<0.25$ & $<0.25$ & $<1.2$ & $<2.5$ & $<25$ & $<5.0$ & $1.6(\mathrm{tr})$ \\
\hline 2-Chlorotoluene & $\mu \mathrm{g} / \mathrm{L}$ & $<0.26$ & $<0.26$ & $<0.26$ & $<0.26$ & $<1.3$ & NA & $<26$ & $<5.2$ & $<0.52$ \\
\hline 4-Chlorotoluene & $\mu \mathrm{g} / \mathrm{L}$ & $<0.10$ & $<0.10$ & $<0.10$ & $<0.10$ & $<0.50$ & NA & $<10$ & $<2.0$ & $<0.20$ \\
\hline Dibromochloromethane & $\mu \mathrm{g} / \mathrm{L}$ & $<0.40$ & $<0.40$ & $<0.40$ & $<0.40$ & $<2.0$ & $<4.0$ & $<40$ & $<8.0$ & $<0.80$ \\
\hline 1,2-Dibromo-3-chloropropane (DBCP) & $\mu \mathrm{g} / \mathrm{L}$ & $<0.22$ & $<0.95$ & $<0.95$ & $<0.95$ & $<4.8$ & $<9.5$ & $<95$ & $<19$ & $<1.9$ \\
\hline 1,2-Dibromoethane (EDB) & $\mu \mathrm{g} / \mathrm{L}$ & $<0.22$ & $<0.21$ & $<0.22$ & $<0.22$ & $<1.1$ & $<2.2$ & $<22$ & $<4.4$ & $<0.44$ \\
\hline Dibromomethane (Methly bromide) & $\mu \mathrm{g} / \mathrm{L}$ & $<0.21$ & $<0.21$ & $<0.21$ & $<0.21$ & $<1.0$ & $<2.1$ & $<21$ & $<4.2$ & $<0.42$ \\
\hline 1,2-Dichlorobenzene & $\mu \mathrm{g} / \mathrm{L}$ & $<0.14$ & $<0.14$ & $<0.14$ & $<0.14$ & $<0.70$ & $<1.4$ & $<14$ & $<2.8$ & $<0.28$ \\
\hline 1,3-Dichlorobenzene & $\mu \mathrm{g} / \mathrm{L}$ & $<0.11$ & $<0.11$ & $<0.11$ & $<0.11$ & $<0.55$ & NA & $<11$ & $<2.2$ & $<0.22$ \\
\hline 1,4-Dichlorobenzene & $\mu \mathrm{g} / \mathrm{L}$ & $<0.13$ & $<0.13$ & $<0.13$ & $<0.13$ & $<0.65$ & $<1.3$ & $<13$ & $<2.6$ & $<0.26$ \\
\hline trans-1,4-Dichloro-2-butene & $\mu \mathrm{g} / \mathrm{L}$ & $<1.0$ & $<1.0$ & $<1.0$ & $<1.0$ & $<5.0$ & $<10$ & $<100$ & $<20$ & $<2.0$ \\
\hline Dichlorodifluoromethane (Freon 12) & $\mu \mathrm{g} / \mathrm{L}$ & $<0.16$ & $0.17(\mathrm{tr})$ & $0.24(\operatorname{tr})$ & $<0.16$ & $<0.80$ & NA & $<16$ & $<3.2$ & $<0.32$ \\
\hline 1,1-Dichloroethane (1,1-DCA) & $\mu \mathrm{g} / \mathrm{L}$ & $0.77(\mathrm{tr})$ & $0.50(\operatorname{tr})$ & $0.77(\operatorname{tr})$ & $0.54(\operatorname{tr})$ & $<0.50$ & $<1.0$ & $<10$ & $<2.0$ & $0.36(\mathrm{tr})$ \\
\hline 1,2-Dichloroethane (1,2-DCA) & $\mu \mathrm{g} / \mathrm{L}$ & $<0.22$ & $<0.22$ & $<0.22$ & $<0.22$ & $<1.1$ & $<2.2$ & $<22$ & $<4.4$ & $<0.44$ \\
\hline 1,1-Dichloroethene (1,1-DCE) & $\mu \mathrm{g} / \mathrm{L}$ & $<0.36$ & $<0.36$ & $<0.36$ & $<0.36$ & $<1.8$ & $<3.6$ & $<36$ & $<7.2$ & $<0.72$ \\
\hline cis-1,2-Dichloroethene (cis-1,2-DCE) & $\mu \mathrm{g} / \mathrm{L}$ & $0.58(\mathrm{tr})$ & 1.2 & 1.8 & 1.5 & $2.3(\mathrm{tr})$ & $1.8(\operatorname{tr})$ & $<10$ & $<2.0$ & $<0.20$ \\
\hline $\begin{array}{l}\text { trans-1,2-Dichloroethene (trans-1,2- } \\
\text { DCE) }\end{array}$ & $\mu \mathrm{g} / \mathrm{L}$ & $<0.11$ & $<0.11$ & $<0.11$ & $<0.11$ & $<0.55$ & $<1.1$ & $<11$ & $<2.2$ & $<0.22$ \\
\hline 1,2-Dichloropropane & $\mu \mathrm{g} / \mathrm{L}$ & $<0.15$ & $<0.15$ & $<0.15$ & $<0.15$ & $<0.75$ & $<1.5$ & $<15$ & $<3.0$ & $<0.30$ \\
\hline 1,3-Dichloropropane & $\mu \mathrm{g} / \mathrm{L}$ & $<0.20$ & $<0.20$ & $<0.20$ & $<0.20$ & $<1.0$ & NA & $<20$ & $<4.0$ & $<0.40$ \\
\hline 2,2 Dichloropropane & $\mu \mathrm{g} / \mathrm{L}$ & $<0.13$ & $<0.13$ & $<0.13$ & $<0.13$ & $<0.65$ & NA & $<13$ & $<2.6$ & $<0.26$ \\
\hline 1,1-Dichloropropene & $\mu \mathrm{g} / \mathrm{L}$ & $<0.14$ & $<0.14$ & $<0.14$ & $<0.14$ & $<0.70$ & NA & $<14$ & $<2.8$ & $<0.28$ \\
\hline cis-1,3-Dichloropropene & $\mu \mathrm{g} / \mathrm{L}$ & $<0.22$ & $<0.22$ & $<0.22$ & $<0.22$ & $<1.1$ & $<2.2$ & $<22$ & $<4.4$ & $<0.44$ \\
\hline trans-1,3-Dichloropropene & $\mu \mathrm{g} / \mathrm{L}$ & $<0.30$ & $<0.30$ & $<0.30$ & $<0.30$ & $<1.5$ & $<3.0$ & $<30$ & $<6.0$ & $<0.60$ \\
\hline Ethylbenzene & $\mu \mathrm{g} / \mathrm{L}$ & $<0.27$ & $<0.27$ & $<0.27$ & $<0.27$ & $<1.4$ & $<2.7$ & $<27$ & $<5.4$ & $<0.54$ \\
\hline Hexachlorobutadiene & $\mu \mathrm{g} / \mathrm{L}$ & $<0.22$ & $<0.22$ & $<0.22$ & $<0.22$ & $<1.1$ & NA & $<22$ & $<4.4$ & $<0.44$ \\
\hline 2-Hexanone (Methyl butyl ketone) & $\mu \mathrm{g} / \mathrm{L}$ & $<1.0$ & $<1.0$ & $<1.0$ & $<1.0$ & $<5.0$ & 26 & $<100$ & $<20$ & $<2.0$ \\
\hline Iodomethane (Methyl iodide) & $\mu \mathrm{g} / \mathrm{L}$ & $<1.0$ & $<1.0$ & $<1.0$ & $<1.0$ & $<5.0$ & $<10$ & $<100$ & $<20$ & $<2.0$ \\
\hline
\end{tabular}




\begin{tabular}{|c|c|c|c|c|c|c|c|c|c|c|}
\hline Isopropylbenzene & $\mu \mathrm{g} / \mathrm{L}$ & $<0.12$ & $<0.12$ & $<0.12$ & $<0.12$ & $<0.60$ & NA & $<12$ & $<2.4$ & $0.43(\mathrm{tr})$ \\
\hline p-Isopropyltoluene & $\mu \mathrm{g} / \mathrm{L}$ & $<0.13$ & $<0.13$ & $0.13(\mathrm{tr})$ & $<0.13$ & $<0.65$ & $\mathrm{NA}$ & $<13$ & $<2.6$ & $<0.26$ \\
\hline Methyl-tert-butyl ether (MTBE) & $\mu \mathrm{g} / \mathrm{L}$ & 14 & 10 & 16 & 6.3 & 44 & 76 & $150(\mathrm{tr})$ & 110 & 8.7 \\
\hline 4-Methyl-2-pentanone (MIBK) & $\mu \mathrm{g} / \mathrm{L}$ & 2 & $<1.0$ & $<1.0$ & $<1.0$ & 100 & 520 & 1000 & 700 & $<2.0$ \\
\hline Methylene Chloride & $\mu \mathrm{g} / \mathrm{L}$ & 1.5 & $<0.35$ & $0.46(\operatorname{tr})$ & $<0.35$ & $<1.8$ & $<3.5$ & $<35$ & $<7.0$ & $<0.70$ \\
\hline Naphthalene & $\mu \mathrm{g} / \mathrm{L}$ & $<0.15$ & $0.45(\operatorname{tr})^{*}$ & $<0.15$ & $<0.15$ & $<0.75$ & NA & $<15$ & $<3.0$ & $<0.30$ \\
\hline n-Propylbenzene & $\mu \mathrm{g} / \mathrm{L}$ & $<0.15$ & $<0.15$ & $<0.15$ & $<0.15$ & $<0.75$ & $\mathrm{NA}$ & $<15$ & $<3.0$ & $<0.30$ \\
\hline Styrene & $\mu \mathrm{g} / \mathrm{L}$ & $<0.15$ & $<0.15$ & $<0.15$ & $<0.15$ & $<0.75$ & $<30$ & $<15$ & $<3.0$ & $<0.30$ \\
\hline 1,1,1,2-Tetrachloroethane & $\mu \mathrm{g} / \mathrm{L}$ & $<0.10$ & $<0.10$ & $<0.10$ & $<0.10$ & $<0.50$ & $<20$ & $<10$ & $<2.0$ & $<0.20$ \\
\hline 1,1,2,2-Tetrachloroethane & $\mu \mathrm{g} / \mathrm{L}$ & $<0.37$ & $<0.37$ & $<0.37$ & $<0.37$ & $<1.8$ & $<74$ & $<37$ & $<7.4$ & $<0.74$ \\
\hline Tetrachloroethene (PCE) & $\mu \mathrm{g} / \mathrm{L}$ & $<0.38$ & $0.84(\operatorname{tr})$ & $<0.38$ & $<0.38$ & $<1.9$ & $<76$ & $<38$ & $<7.6$ & $<0.76$ \\
\hline Toluene & $\mu \mathrm{g} / \mathrm{L}$ & $1.3 *$ & $0.98(\operatorname{tr})$ & 2.9 & $0.44(\mathrm{tr})$ & 8.3 & $<50$ & $<25$ & 24 & $<0.50$ \\
\hline 1,2,3-Trichlorobenzene & $\mu \mathrm{g} / \mathrm{L}$ & $<0.14$ & $<0.14$ & $<0.14$ & $<0.14$ & $<0.70$ & $\mathrm{NA}$ & $<14$ & $<2.8$ & $<0.28$ \\
\hline 1,2,4-Trichlorobenzene & $\mu \mathrm{g} / \mathrm{L}$ & $<0.23$ & $<0.23$ & $<0.23$ & $<0.23$ & $<1.2$ & NA & $<23$ & $<4.6$ & $<0.46$ \\
\hline 1,1,1-Trichloroethane $(1,1,1$-TCA) & $\mu \mathrm{g} / \mathrm{L}$ & $<0.41$ & $<0.41$ & $<0.41$ & $<0.41$ & $<2.0$ & $<82$ & $<41$ & $<8.2$ & $<0.82$ \\
\hline 1,1,2-Trichloroethane $(1,1,2$-TCA) & $\mu \mathrm{g} / \mathrm{L}$ & $<0.31$ & $<0.31$ & $<0.31$ & $<0.31$ & $<1.6$ & $<62$ & $<31$ & $<6.2$ & $<0.62$ \\
\hline Trichloroethene (TCE) & $\mu \mathrm{g} / \mathrm{L}$ & $0.33(\mathrm{tr})$ & $0.77(\operatorname{tr})$ & $<0.31$ & $0.46(\mathrm{tr})$ & $<1.6$ & $<62$ & $<31$ & $<6.2$ & $<0.62$ \\
\hline Trichlorofluoromethane (Freon 11) & $\mu \mathrm{g} / \mathrm{L}$ & $<0.23$ & $<0.23$ & $<0.23$ & $<0.23$ & $<1.2$ & $<46$ & $<23$ & $<4.6$ & $<0.46$ \\
\hline 1,2,3-Trichloropropane & $\mu \mathrm{g} / \mathrm{L}$ & $<0.30$ & $<0.30$ & $<0.30$ & $<0.30$ & $<1.5$ & $<60$ & $<30$ & $<6.0$ & $<0.60$ \\
\hline 1,2,4-Trimethylbenzene & $\mu \mathrm{g} / \mathrm{L}$ & $<0.12$ & $<0.12$ & $<0.12$ & $<0.12$ & $<0.60$ & NA & $<12$ & $<2.4$ & $<0.24$ \\
\hline 1,3,5-Trimethylbenzene & $\mu \mathrm{g} / \mathrm{L}$ & $<0.14$ & $0.27(\operatorname{tr})$ & $<0.14$ & $<0.14$ & $<0.70$ & NA & $<14$ & $<2.8$ & $<0.28$ \\
\hline Vinyl Acetate & $\mu \mathrm{g} / \mathrm{L}$ & $<1.0$ & $<1.0$ & $<1.0$ & $<1.0$ & $<5.0$ & $<200$ & $<100$ & $<20$ & $<2.0$ \\
\hline Vinyl Chloride & $\mu \mathrm{g} / \mathrm{L}$ & $<0.12$ & $<0.12$ & $0.30(\mathrm{tr})$ & $<0.12$ & $<0.60$ & $<24$ & $<12$ & $<2.4$ & $<0.24$ \\
\hline Total Xylenes & $\mu \mathrm{g} / \mathrm{L}$ & $<0.10$ & 0.13 (tr) & $0.30(\mathrm{tr})$ & $<0.10$ & $<0.50$ & $<20$ & $<10$ & $2.5(\mathrm{tr})$ & $<0.20$ \\
\hline
\end{tabular}

\section{Footnotes:}

$\mathrm{NA}=$ Not Analyzed

MDL=Method Detection Limit

$\mathrm{PQL}=$ Practical Quantification Limit

$<=$ Less than the MDL

tr=trace: the amount detected was above the MDL but below the PQL

* = this parameter was alo detected in the method blank 
Table 4-7. Analytical Results for Leachate Sampled from the West-Side Anaerobic Cell

\begin{tabular}{|c|c|c|c|c|c|c|c|c|}
\hline PARAMETER & DATE: & $2 / 14 / 2002$ & $3 / 27 / 2002$ & $5 / 14 / 2002$ & $6 / 20 / 2002$ & $7 / 23 / 2002$ & $8 / 13 / 2002$ & $2 / 26 / 2003$ \\
\hline \multicolumn{9}{|l|}{ Field Parameters: } \\
\hline $\mathrm{pH}$ & & 6.74 & 6.76 & 6.8 & 6.72 & 6.85 & 6.71 & 6.87 \\
\hline Electrical Conductivity & $\mu \mathrm{S}$ & 3530 & 3868 & 3851 & 3944 & 3899 & 3810 & 2320 \\
\hline Oxidation Reduction Potential & $\mathrm{mV}$ & -62 & -59 & -46 & -19 & -38 & -36 & -56 \\
\hline Temperature & $\mathrm{C}$ & 24.9 & 25.9 & 26.2 & 25.2 & 25.7 & 26.9 & 22.1 \\
\hline Dissolved Oxygen & $\mathrm{mg} / \mathrm{L}$ & 3.15 & 1.09 & 1.54 & 1.31 & 3.62 & 2.6 & 3.18 \\
\hline Total Dissolved Solids & ppm & 2617 & 2886 & 2871 & 2960 & 2965 & 2908 & 1703 \\
\hline \multicolumn{9}{|l|}{ General Chemistry: } \\
\hline Bicarbonate Alkalinity & $\mathrm{mg} / \mathrm{L}$ & 1700 & 1790 & 1780 & 1730 & 1710 & 1680 & 1000 \\
\hline Carbonate Alkalinity & $\mathrm{mg} / \mathrm{L}$ & $<5.0$ & $<5.0$ & $<5.0$ & $<5.0$ & $<5.0$ & $<5.0$ & $<5.0$ \\
\hline Total Alkalinity as $\mathrm{CO}_{3}$ & $\mathrm{mg} / \mathrm{L}$ & 1700 & 1790 & 1780 & 1730 & 1710 & 1680 & 1000 \\
\hline BOD & $\mathrm{mg} \mathrm{O} / \mathrm{L}$ & 28 & 18 & 12 & 12 & 7.9 & 12 & 16 \\
\hline Chemical Oxygen Demand & $\mathrm{mg} \mathrm{O} / \mathrm{L}$ & 350 & 317 & 300 & 274 & 270 & 262 & 98.1 \\
\hline Chloride & $\mathrm{mg} / \mathrm{L}$ & 187 & 323 & 333 & 358 & 341 & 366 & 196 \\
\hline Hydroxide & $\mathrm{mg} / \mathrm{L}$ & $<5.0$ & $<5.0$ & $<5.0$ & $<5.0$ & $<5.0$ & $<5.0$ & $<5.0$ \\
\hline Ammonia as $\mathrm{N}$ & $\mathrm{mg} / \mathrm{L}$ & 20.3 & 20 & 23.5 & 21.2 & 23.8 & 25 & 9.5 \\
\hline \begin{tabular}{|l|} 
Nitrate-Nitrite as $\mathrm{N}$ \\
\end{tabular} & $\mathrm{mg} / \mathrm{L}$ & $0.016(\operatorname{tr})$ & $<0.015$ & $<1.5$ & $<0.03$ & $<0.015$ & $<0.015$ & $0.022(\operatorname{tr})$ \\
\hline Total Kjeldahl Nitrogen & $\mathrm{mg} / \mathrm{L}$ & 32.6 & 68.9 & 31.1 & 31.5 & 31.4 & 31 & 13.8 \\
\hline Sulfate & $\mathrm{mg} / \mathrm{L}$ & $1.7(\mathrm{tr})$ & $1.5(\operatorname{tr})$ & $<10$ & $0.80(\mathrm{tr})$ & 2.2 & $0.75(\mathrm{tr})$ & $<0.70$ \\
\hline Total Dissolved Solids @ 180 C & $\mathrm{mg} / \mathrm{L}$ & 2220 & 2380 & 2320 & 2410 & 2310 & 2280 & 1320 \\
\hline Total (Non-Volatile) Organic Carbon & $\mathrm{mg} / \mathrm{L}$ & 112 & 95.7 & 85.2 & 86.5 & 82.7 & 78.1 & 28.3 \\
\hline Total Phosphorus & $\mathrm{mg} / \mathrm{L}$ & 0.13 & $1.6^{*}$ & 1.1 & 0.6 & 0.057 & $0.049(\operatorname{tr})$ & $<0.12$ \\
\hline Total Sulfide & $\mathrm{mg} / \mathrm{L}$ & $0.033(\operatorname{tr})$ & $0.015(\operatorname{tr})$ & $<0.014$ & $<0.014$ & $0.023(\mathrm{tr})$ & $<0.014$ & $<0.0093$ \\
\hline \multicolumn{9}{|l|}{ Metals: } \\
\hline Dissolved Aluminum & $\mathrm{mg} / \mathrm{L}$ & $0.13(\operatorname{tr})$ & $<0.043$ & $0.053(\mathrm{tr})^{*}$ & $<0.043$ & $<0.043$ & $<0.043$ & $<0.043$ \\
\hline Dissolved Antimony & $\mathrm{mg} / \mathrm{L}$ & $0.0013(\mathrm{tr})$ & $0.00091(\mathrm{tr})$ & $0.00065(\mathrm{tr})$ & $0.0006(\mathrm{tr})$ & $0.0008(\operatorname{tr})$ & $<0.031$ & $0.00090(\mathrm{tr})$ \\
\hline Dissolved Arsenic & $\mathrm{mg} / \mathrm{L}$ & 0.27 & 0.02 & 0.018 & 0.019 & 0.017 & 0.01 & 0.012 \\
\hline Dissolved Barium & $\mathrm{mg} / \mathrm{L}$ & 1.8 & 1.8 & 0.45 & 1.8 & 1.6 & 1.4 & 1.1 \\
\hline Dissolved Beryllium & $\mathrm{mg} / \mathrm{L}$ & $<0.000078$ & $<0.000078$ & $<0.000078$ & $<0.000078$ & $<0.000078$ & $<0.00009$ & $<0.000078$ \\
\hline
\end{tabular}




\begin{tabular}{|c|c|c|c|c|c|c|c|c|}
\hline Dissolved Boron & $\mathrm{mg} / \mathrm{L}$ & 3.2 & 3.5 & 18.9 & NA & 3.7 & 3.2 & $<0.000078$ \\
\hline Dissolved Cadmium & $\mathrm{mg} / \mathrm{L}$ & $<0.000074$ & $<0.000074$ & $<0.000074$ & $<0.000074$ & $<0.000074$ & $<0.0031$ & $<0.000074$ \\
\hline Dissolvd Calcium & $\mathrm{mg} / \mathrm{L}$ & 241 & 234 & 58.2 & NA & 231 & 193 & 108 \\
\hline Dissolved Chromium & $\mathrm{mg} / \mathrm{L}$ & 0.0088 & 0.0069 & 0.0064 & 0.0059 & 0.0054 & $0.0035(\mathrm{tr})$ & $0.0019(\mathrm{tr})$ \\
\hline Dissolved Cobalt & $\mathrm{mg} / \mathrm{L}$ & 0.0038 & 0.0043 & 0.003 & 0.0025 & 0.0025 & $<0.0074$ & 0.0015 \\
\hline Dissolved Copper & $\mathrm{mg} / \mathrm{L}$ & $0.0018(\mathrm{tr})$ & 0.0022 & $0.0011(\mathrm{tr})^{*}$ & 0.002 & 0.0023 & 0.0035 (tr) & $0.002 *$ \\
\hline Dissolved Iron & $\mathrm{mg} / \mathrm{L}$ & 0.4 & 1.2 & $0.035(\mathrm{tr})^{*}$ & 1.9 & 0.59 & 0.11 & 0.15 \\
\hline Dissolved Lead & $\mathrm{mg} / \mathrm{L}$ & $0.00024(\mathrm{tr})$ & $0.000066(\mathrm{tr})$ & $0.000078(\operatorname{tr})^{*}$ & $<0.000066$ & $<0.000066$ & $<0.000066$ & $<0.000066$ \\
\hline Dissolved Magnesium & $\mathrm{mg} / \mathrm{L}$ & 198 & 211 & 343 & NA & 217 & 185 & 123 \\
\hline Dissolved Manganese & $\mathrm{mg} / \mathrm{L}$ & 24.6 & 22.9 & $0.0062(\mathrm{tr})$ & 21.4 & 19.3 & 15.9 & 10.9 \\
\hline Dissolved Mercury & $\mathrm{mg} / \mathrm{L}$ & $<0.000049$ & $<0.000049$ & $<0.000049$ & $<0.000049$ & $<0.000049$ & $0.000078(\operatorname{tr})^{*}$ & $<0.000064$ \\
\hline Dissolved Molybdenum & $\mathrm{mg} / \mathrm{L}$ & $<0.0046$ & $<0.0046$ & 0.044 & $<0.0046$ & $<0.0046$ & $<0.0046$ & $<0.0046$ \\
\hline Dissolved Nickel & $\mathrm{mg} / \mathrm{L}$ & 0.042 & 0.053 & 0.052 & 0.047 & 0.046 & 0.041 & 0.018 \\
\hline Dissolved Potassium & $\mathrm{mg} / \mathrm{L}$ & 55.2 & 48.3 & 58.6 & NA & 37.8 & 32.5 & 23.7 \\
\hline Dissolved Phosphorus & $\mathrm{mg} / \mathrm{L}$ & $0.28(\mathrm{tr})$ & $0.14(\mathrm{tr})$ & 1 & NA & $<0.12$ & $<0.12$ & $<0.12$ \\
\hline Dissolved Selenium & $\mathrm{mg} / \mathrm{L}$ & $<0.0017$ & $<0.0017$ & $<0.0017$ & $<0.0017$ & 0.002 & $<0.0017$ & $<0.0017$ \\
\hline Dissolved Silver & $\mathrm{mg} / \mathrm{L}$ & $<0.00003$ & $<0.00003$ & $<0.00003$ & $<0.00003$ & $<0.00003$ & $<0.0032$ & $<0.000030$ \\
\hline Dissolved Sodium & $\mathrm{mg} / \mathrm{L}$ & 260 & 281 & $1500^{*}$ & $\mathrm{NA}$ & 268 & 234 & 226 \\
\hline Dissolved Thallium & $\mathrm{mg} / \mathrm{L}$ & $<0.00034$ & $<0.00034$ & $<0.00034$ & $<0.00034$ & $<0.00034$ & $<0.00034$ & $<0.00034$ \\
\hline Dissolved Tin & $\mathrm{mg} / \mathrm{L}$ & $<0.022$ & $<0.022$ & $<0.022$ & $<0.022$ & $<0.022$ & $<0.022$ & $<0.0014$ \\
\hline Dissolved Vanadium & $\mathrm{mg} / \mathrm{L}$ & $0.0056(\mathrm{tr})$ & $0.0038(\operatorname{tr})$ & $0.017(\operatorname{tr})$ & $<0.0032$ & $<0.0032$ & $<0.0032$ & $<0.0032$ \\
\hline Dissolved Zinc & $\mathrm{mg} / \mathrm{L}$ & 0.068 & 0.07 & 0.039 & 0.037 & 0.05 & $0.006(\operatorname{tr})$ & 0.042 \\
\hline \multicolumn{9}{|l|}{ Volatile Organic Compounds: } \\
\hline Acetone & $\mu \mathrm{g} / \mathrm{L}$ & $<50$ & 28 & 22 & 22 & 14(tr)* & $33(\operatorname{tr})$ & $13(\mathrm{tr})$ \\
\hline Acrylonitrile & $\mu \mathrm{g} / \mathrm{L}$ & $<500$ & $<100$ & $<100$ & $<100$ & $<50$ & $<100$ & $<50$ \\
\hline Benzene & $\mu \mathrm{g} / \mathrm{L}$ & $<6.5$ & $3.3(\operatorname{tr})^{*}$ & $2.3(\operatorname{tr})$ & $<1.3$ & $3.5(\mathrm{tr})$ & $3.6(\operatorname{tr})$ & $2.6(\mathrm{tr})$ \\
\hline Bromobenzene & $\mu \mathrm{g} / \mathrm{L}$ & $<9.0$ & $<1.8$ & $<1.8$ & $<1.8$ & $<0.90$ & NA & $<0.90$ \\
\hline Bromochloromethane & $\mu \mathrm{g} / \mathrm{L}$ & $<16$ & $<3.1$ & $<3.1$ & $<3.1$ & $<1.6$ & $<3.1$ & $<1.6$ \\
\hline Bromodichloromethane & $\mu \mathrm{g} / \mathrm{L}$ & $<7.0$ & $<1.4$ & $<1.4$ & $<1.4$ & $<0.70$ & $<1.4$ & $<0.70$ \\
\hline Bromoform & $\mu \mathrm{g} / \mathrm{L}$ & $<5.0$ & $<1.0$ & $<1.0$ & $<1.0$ & $<0.50$ & $<1.0$ & $<0.50$ \\
\hline Bromomethane (Methly bromide) & $\mu \mathrm{g} / \mathrm{L}$ & $<4.0$ & $<0.80$ & $<0.80$ & $<0.80$ & $4.6(\operatorname{tr})^{*}$ & $<0.80$ & $<0.40$ \\
\hline 2-Butanone (MEK) & $\mu \mathrm{g} / \mathrm{L}$ & $<50$ & $<10$ & $<10$ & $<10$ & $<5.0$ & $<10$ & $<5.0$ \\
\hline n-Butylbenzene & $\mu \mathrm{g} / \mathrm{L}$ & $<6.0$ & $<1.2$ & $<1.2$ & $<1.2$ & $<0.60$ & NA & $<0.60$ \\
\hline
\end{tabular}




\begin{tabular}{|c|c|c|c|c|c|c|c|c|}
\hline sec-Butylbenzene & $\mu \mathrm{g} / \mathrm{L}$ & $<6.0$ & $<1.2$ & $<1.2$ & $<1.2$ & $<0.60$ & NA & $<0.60$ \\
\hline tert-Butylbenzene & $\mu \mathrm{g} / \mathrm{L}$ & $<7.0$ & $<1.4$ & $<1.4$ & $<1.4$ & $<0.70$ & NA & $<0.70$ \\
\hline Carbon Disulfide & $\mu \mathrm{g} / \mathrm{L}$ & $<50$ & $<10$ & $<10$ & $<10$ & $<5.0$ & $<10$ & $<5.0$ \\
\hline Carbon Tetrachloride & $\mu \mathrm{g} / \mathrm{L}$ & $<7.5$ & $<1.5$ & $<1.5$ & $<1.5$ & $<0.75$ & $<1.5$ & $<0.75$ \\
\hline Chlorobenzene & $\mu \mathrm{g} / \mathrm{L}$ & $<6.0$ & $<1.2$ & $<1.2$ & $<1.2$ & $<0.60$ & $<1.2$ & $<0.60$ \\
\hline Chloroethane & $\mu \mathrm{g} / \mathrm{L}$ & $<17$ & $<3.4$ & $<3.4$ & $<3.4$ & $<1.7$ & $<3.4$ & $3.1(\mathrm{tr})$ \\
\hline Chloroform & $\mu \mathrm{g} / \mathrm{L}$ & $<6.0$ & $<1.2$ & $<1.2$ & $<1.2$ & $<0.60$ & $<1.2$ & $<0.60$ \\
\hline Chloromethane (Methyl chloride) & $\mu \mathrm{g} / \mathrm{L}$ & $<12$ & $<2.5$ & $<2.5$ & $<2.5$ & $<1.2$ & $<2.5$ & $<1.2$ \\
\hline 2-Chlorotoluene & $\mu \mathrm{g} / \mathrm{L}$ & $<13$ & $<2.6$ & $<2.6$ & $<2.6$ & $<1.3$ & NA & $<1.3$ \\
\hline 4-Chlorotoluene & $\mu \mathrm{g} / \mathrm{L}$ & $<5.0$ & $<1.0$ & $<1.0$ & $<1.0$ & $<0.50$ & NA & $<0.50$ \\
\hline Dibromochloromethane & $\mu \mathrm{g} / \mathrm{L}$ & $<20$ & $<4.0$ & $<4.0$ & $<4.0$ & $<2.0$ & $<4.0$ & $<2.0$ \\
\hline 1,2-Dibromo-3-chloropropane (DBCP) & $\mu \mathrm{g} / \mathrm{L}$ & $<48$ & $<9.5$ & $<9.5$ & $<9.5$ & $<4.8$ & $<9.5$ & $<4.8$ \\
\hline 1,2-Dibromoethane (EDB) & $\mu \mathrm{g} / \mathrm{L}$ & $<11$ & $<2.2$ & $<2.2$ & $<2.2$ & $<1.1$ & $<2.2$ & $<1.1$ \\
\hline Dibromomethane (Methly bromide) & $\mu \mathrm{g} / \mathrm{L}$ & $<10$ & $<2.1$ & $<2.1$ & $<2.1$ & $<1.0$ & $<2.1$ & $<1.0$ \\
\hline 1,2-Dichlorobenzene & $\mu \mathrm{g} / \mathrm{L}$ & $<7.0$ & $<1.4$ & $<1.4$ & $<1.4$ & $<0.70$ & $<1.4$ & $<0.70$ \\
\hline 1,3-Dichlorobenzene & $\mu \mathrm{g} / \mathrm{L}$ & $<5.5$ & $<1.1$ & $<1.1$ & $<1.1$ & $<0.55$ & NA & $<0.55$ \\
\hline 1,4-Dichlorobenzene & $\mu \mathrm{g} / \mathrm{L}$ & $<6.5$ & $<1.3$ & $<1.3$ & $<1.3$ & $<0.65$ & $<1.3$ & $<0.65$ \\
\hline trans-1,4-Dichloro-2-butene & $\mu \mathrm{g} / \mathrm{L}$ & $<50$ & $<10$ & $<10$ & $<10$ & $<5.0$ & $<10$ & $<5.0$ \\
\hline Dichlorodifluoromethane (Freon 12) & $\mu \mathrm{g} / \mathrm{L}$ & $<8.0$ & $2.4(\operatorname{tr})$ & $4.2(\operatorname{tr})$ & $<1.6$ & 16 & NA & $<0.80$ \\
\hline 1,1-Dichloroethane (1,1-DCA) & $\mu \mathrm{g} / \mathrm{L}$ & $<5.0$ & $4.6(\operatorname{tr})$ & 7.4(tr) & $9.5(\operatorname{tr})$ & 12 & 13 & $1.5(\mathrm{tr})$ \\
\hline 1,2-Dichloroethane (1,2-DCA) & $\mu \mathrm{g} / \mathrm{L}$ & $<11$ & $2.5(\operatorname{tr})$ & $3.5(\operatorname{tr})$ & $4.0(\operatorname{tr})$ & $4.8(\operatorname{tr})$ & $5.8(\operatorname{tr})$ & $4.0(\operatorname{tr})$ \\
\hline 1,1-Dichloroethene (1,1-DCE) & $\mathrm{ug} / \mathrm{L}$ & $<18$ & $<3.6$ & $<3.6$ & $<3.6$ & $<1.8$ & $<3.6$ & $<1.8$ \\
\hline cis-1,2-Dichloroethene (cis-1,2-DCE) & $\mu \mathrm{g} / \mathrm{L}$ & $<5.0$ & $2.3(\mathrm{tr})$ & 1.9 (tr) & $<1.0$ & $3.3(\operatorname{tr})$ & $3.5(\operatorname{tr})$ & 3.7 (tr) \\
\hline $\begin{array}{l}\text { trans-1,2-Dichloroethene (trans-1,2- } \\
\text { DCE) }\end{array}$ & $\mu \mathrm{g} / \mathrm{L}$ & $<5.5$ & $<1.1$ & $<1.1$ & $<1.1$ & $<0.55$ & $<1.1$ & $<0.55$ \\
\hline 1,2-Dichloropropane & $\mu \mathrm{g} / \mathrm{L}$ & $<7.5$ & $<1.5$ & $<1.5$ & $<1.5$ & $<0.75$ & $<1.5$ & $<0.75$ \\
\hline 1,3-Dichloropropane & $\mu \mathrm{g} / \mathrm{L}$ & $<10$ & $<2.0$ & $<2.0$ & $<2.0$ & $<1.0$ & NA & $<1.0$ \\
\hline 2,2 Dichloropropane & $\mu \mathrm{g} / \mathrm{L}$ & $<6.5$ & $<1.3$ & $<1.3$ & $<1.3$ & $<0.65$ & NA & $<0.65$ \\
\hline 1,1-Dichloropropene & $\mu \mathrm{g} / \mathrm{L}$ & $<7.0$ & $<1.4$ & $<1.4$ & $<1.4$ & $<0.70$ & NA & $<0.70$ \\
\hline cis-1,3-Dichloropropene & $\mu \mathrm{g} / \mathrm{L}$ & $<11$ & $<2.2$ & $<2.2$ & $<2.2$ & $<1.1$ & $<2.2$ & $<1.1$ \\
\hline trans-1,3-Dichloropropene & $\mu \mathrm{g} / \mathrm{L}$ & $<15$ & $<3.0$ & $<3.0$ & $<3.0$ & $<1.5$ & $<3.0$ & $<1.5$ \\
\hline Ethylbenzene & $\mu \mathrm{g} / \mathrm{L}$ & $<14$ & $<2.7$ & $<2.7$ & $<2.7$ & $<1.4$ & $<2.7$ & $1.4(\mathrm{tr})$ \\
\hline Hexachlorobutadiene & $\mu \mathrm{g} / \mathrm{L}$ & $<11$ & $<2.2$ & $<2.2$ & $<2.2$ & $<1.1$ & NA & $<1.1$ \\
\hline 2-Hexanone (Methyl butyl ketone) & $\mu \mathrm{g} / \mathrm{L}$ & $<50$ & $<10$ & $<10$ & $<10$ & $<5.0$ & $<10$ & $<5.0$ \\
\hline
\end{tabular}




\begin{tabular}{|c|c|c|c|c|c|c|c|c|}
\hline Iodomethane (Methyl iodide) & $\mu \mathrm{g} / \mathrm{L}$ & $<50$ & $<10$ & $<10$ & $<10$ & $<5.0$ & $<10$ & $<5.0$ \\
\hline Isopropylbenzene & $\mu \mathrm{g} / \mathrm{L}$ & $<6.0$ & $<1.2$ & $<1.2$ & $<1.2$ & $<0.60$ & NA & $<0.60$ \\
\hline p-Isopropyltoluene & $\mu \mathrm{g} / \mathrm{L}$ & $<6.5$ & $<1.3$ & $<1.3$ & $<1.3$ & $<0.65$ & NA & $<0.65$ \\
\hline Methyl-tert-butyl ether (MTBE) & $\mu \mathrm{g} / \mathrm{L}$ & 210 & 190 & 160 & 160 & 180 & 170 & 110 \\
\hline 4-Methyl-2-pentanone (MIBK) & $\mu \mathrm{g} / \mathrm{L}$ & 1200 & $19(\mathrm{tr})$ & 52 & $<10$ & $<5.0$ & 26 & $7.1(\mathrm{tr})$ \\
\hline Methylene Chloride & $\mu \mathrm{g} / \mathrm{L}$ & $<18$ & $<3.5$ & $<3.5$ & $<3.5$ & $2.1(\mathrm{tr})$ & $<3.5$ & $<1.8$ \\
\hline Naphthalene & $\mu \mathrm{g} / \mathrm{L}$ & $<7.5$ & $<1.5$ & $<1.5$ & $<1.5$ & $<0.75$ & NA & $<0.75$ \\
\hline n-Propylbenzene & $\mu \mathrm{g} / \mathrm{L}$ & $<7.5$ & $<1.5$ & $<1.5$ & $<1.5$ & $<0.75$ & NA & $<0.75$ \\
\hline Styrene & $\mu \mathrm{g} / \mathrm{L}$ & $<7.5$ & $<1.5$ & $<1.5$ & $<1.5$ & $<0.75$ & $<1.5$ & $<0.75$ \\
\hline $1,1,1,2$-Tetrachloroethane & $\mu \mathrm{g} / \mathrm{L}$ & $<5.0$ & $<1.0$ & $<1.0$ & $<1.0$ & $<0.50$ & $<1.0$ & $<0.50$ \\
\hline 1,1,2,2-Tetrachloroethane & $\mu \mathrm{g} / \mathrm{L}$ & $<18$ & $<3.7$ & $<3.7$ & $<3.7$ & $<1.8$ & $<3.7$ & $<1.8$ \\
\hline Tetrachloroethene (PCE) & $\mu \mathrm{g} / \mathrm{L}$ & $<19$ & $<3.8$ & $<3.8$ & $<3.8$ & $<1.9$ & NA & $<1.9$ \\
\hline Toluene & $\mu \mathrm{g} / \mathrm{L}$ & $150 *$ & 42 & 20 & 22 & 22 & 20 & 14 \\
\hline 1,2,3-Trichlorobenzene & $\mu \mathrm{g} / \mathrm{L}$ & $<7.0$ & $<1.4$ & $<1.4$ & $<1.4$ & $<0.70$ & NA & $<0.70$ \\
\hline 1,2,4-Trichlorobenzene & $\mu \mathrm{g} / \mathrm{L}$ & $<12$ & $<2.3$ & $<2.3$ & $<2.3$ & $<1.2$ & NA & $<1.2$ \\
\hline 1,1,1-Trichloroethane $(1,1,1-\mathrm{TCA})$ & $\mu \mathrm{g} / \mathrm{L}$ & $<20$ & $<4.1$ & $<4.1$ & $<4.1$ & $<2.0$ & $<4.1$ & $<2.0$ \\
\hline 1,1,2-Trichloroethane (1,1,2-TCA) & $\mu \mathrm{g} / \mathrm{L}$ & $<16$ & $<3.1$ & $<3.1$ & $<3.1$ & $<1.6$ & $<3.1$ & $<1.6$ \\
\hline Trichloroethene (TCE) & $\mu \mathrm{g} / \mathrm{L}$ & $<16$ & $<3.1$ & $<3.1$ & $<3.1$ & $<1.6$ & $<3.1$ & $<1.6$ \\
\hline Trichlorofluoromethane (Freon 11) & $\mu \mathrm{g} / \mathrm{L}$ & $<12$ & $<2.3$ & $2.7(\operatorname{tr})$ & $<2.3$ & $<1.2$ & $<2.3$ & $<1.2$ \\
\hline 1,2,3-Trichloropropane & $\mu \mathrm{g} / \mathrm{L}$ & $<15$ & $<3.0$ & $<3.0$ & $<3.0$ & $<1.5$ & $<3.0$ & $<1.5$ \\
\hline 1,2,4-Trimethylbenzene & $\mu \mathrm{g} / \mathrm{L}$ & $<6.0$ & $<1.2$ & $<1.2$ & $<1.2$ & $<0.60$ & NA & $<0.60$ \\
\hline 1,3,5-Trimethylbenzene & $\mu \mathrm{g} / \mathrm{L}$ & $<7.0$ & $<1.4$ & $<1.4$ & $<1.4$ & $<0.70$ & NA & $<0.70$ \\
\hline Vinyl Acetate & $\mu \mathrm{g} / \mathrm{L}$ & $<50$ & $<10$ & $<10$ & $<10$ & $<5.0$ & $<10$ & $<5.0$ \\
\hline Vinyl Chloride & $\mu \mathrm{g} / \mathrm{L}$ & $<6.0$ & $<1.2$ & $<1.2$ & $<1.2$ & $<0.60$ & $<1.2$ & $2.3(\mathrm{tr})$ \\
\hline Total Xylenes & $\mu \mathrm{g} / \mathrm{L}$ & $<5.0$ & $4.0(\operatorname{tr})$ & $3.8(\mathrm{tr})$ & $<1.0$ & $3.4(\operatorname{tr})$ & $4.0(\operatorname{tr})$ & $2.8(\mathrm{tr})$ \\
\hline
\end{tabular}

\section{Footnotes:}

NA=Not Analyzed

MDL=Method Detection Limit

$P Q L=$ Practical Quantification Limit

$<=$ Less than the MDL

tr=trace: the amount detected was above the MDL but below the PQL

* = this parameter was alo detected in the method blank 
Table 5-7. Analytical Results for Leachate Sampled form the Aerobic Cell Manhole

\begin{tabular}{|c|c|c|c|c|}
\hline PARAMETER & DATE: & $2 / 26 / 2002$ & $3 / 27 / 2002$ & $5 / 14 / 2002$ \\
\hline Field Parameters: & Units & & & \\
\hline $\mathrm{pH}$ & & 7.75 & 8.17 & 8.48 \\
\hline Electrical Conductivity & $\mu \mathrm{S}$ & 7026 & 7705 & 9048 \\
\hline Oxidation Reduction Potential & $\mathrm{mV}$ & 195 & 195 & 127 \\
\hline Temperature & $\mathrm{C}$ & 15.1 & 15.2 & 21.1 \\
\hline Dissolved Oxygen & $\mathrm{mg} / \mathrm{L}$ & 5.45 & 5.73 & 6.8 \\
\hline Total Dissolved Solids & $\mathrm{ppm}$ & 5673 & NA & 7448 \\
\hline \multicolumn{5}{|l|}{ General Chemistry: } \\
\hline Bicarbonate Alkalinity & $\mathrm{mg} / \mathrm{L}$ & 1120 & 935 & 1020 \\
\hline Carbonate Alkalinity & $\mathrm{mg} / \mathrm{L}$ & NA & $<5.0$ & 24.8 \\
\hline Total Alkalinity as $\mathrm{CO}_{3}$ & $\mathrm{mg} / \mathrm{L}$ & 1120 & 935 & 1050 \\
\hline BOD & $\mathrm{mg} \mathrm{O} / \mathrm{L}$ & 3.3 & 5 & 89 \\
\hline Chemical Oxygen Demand & $\mathrm{mg} \mathrm{O} / \mathrm{L}$ & 595 & 563 & 602 \\
\hline Chloride & $\mathrm{mg} / \mathrm{L}$ & 1610 & 1800 & 2290 \\
\hline Hydroxide & $\mathrm{mg} / \mathrm{L}$ & $<5.0$ & $<5.0$ & $<5.0$ \\
\hline Ammonia as $\mathrm{N}$ & $\mathrm{mg} / \mathrm{L}$ & 2.8 & 1.1 & 0.60 (tr) \\
\hline Nitrate-Nitrite as N & $\mathrm{mg} / \mathrm{L}$ & 0.16 & 0.22 & $4.8(\operatorname{tr})$ \\
\hline Total Kjeldahl Nitrogen & $\mathrm{mg} / \mathrm{L}$ & 19.9 & 19.2 & 11.1 \\
\hline Sulfate & $\mathrm{mg} / \mathrm{L}$ & 290 & 478 & 526 \\
\hline Total Dissolved Solids @ 180 C & $\mathrm{mg} / \mathrm{L}$ & 4810 & 5200 & 5640 \\
\hline Total (Non-Volatile) Organic Carbon & $\mathrm{mg} / \mathrm{L}$ & 766 & 149 & 168 \\
\hline Total Phosphorus & $\mathrm{mg} / \mathrm{L}$ & 0.51 & 0.19 & $0.85^{*}$ \\
\hline Total Sulfide & $\mathrm{mg} / \mathrm{L}$ & $<0.014$ & $0.015(\mathrm{tr})$ & $<0.014$ \\
\hline \multicolumn{5}{|l|}{ Metals: } \\
\hline Dissolved Aluminum & $\mathrm{mg} / \mathrm{L}$ & $<0.043$ & $<0.043$ & $0.082(\mathrm{tr})^{*}$ \\
\hline Dissolved Antimony & $\mathrm{mg} / \mathrm{L}$ & 0.002 & $0.0016(\mathrm{tr})$ & 0.002 \\
\hline Dissolved Arsenic & $\mathrm{mg} / \mathrm{L}$ & 0.012 & 0.015 & 0.017 \\
\hline Dissolved Barium & $\mathrm{mg} / \mathrm{L}$ & 0.43 & 0.54 & 1.9 \\
\hline Dissolved Beryllium & $\mathrm{mg} / \mathrm{L}$ & $<0.000078$ & $<0.000078$ & $<0.000078$ \\
\hline Dissolved Boron & $\mathrm{mg} / \mathrm{L}$ & NA & 12.2 & 3.8 \\
\hline Dissolved Cadmium & $\mathrm{mg} / \mathrm{L}$ & $0.00013(\mathrm{tr})$ & $0.00016(\mathrm{tr})$ & 0.0062 \\
\hline Dissolvd Calcium & $\mathrm{mg} / \mathrm{L}$ & NA & 57 & 257 \\
\hline Dissolved Chromium & $\mathrm{mg} / \mathrm{L}$ & 0.01 & 0.0062 & 0.0062 \\
\hline Dissolved Cobalt & $\mathrm{mg} / \mathrm{L}$ & 0.0095 & 0.0073 & 0.004 \\
\hline Dissolved Copper & $\mathrm{mg} / \mathrm{L}$ & 0.016 & 0.014 & 0.019 \\
\hline Dissolved Iron & $\mathrm{mg} / \mathrm{L}$ & 0.32 & $0.084(\operatorname{tr})$ & 0.34 \\
\hline Dissolved Lead & $\mathrm{mg} / \mathrm{L}$ & $0.00026(\mathrm{tr})$ & $<0.000066$ & $0.00061(\mathrm{tr})$ \\
\hline Dissolved Magnesium & $\mathrm{mg} / \mathrm{L}$ & 273 & 260 & 220 \\
\hline Dissolved Manganese & $\mathrm{mg} / \mathrm{L}$ & 1.1 & 0.77 & 23.9 \\
\hline Dissolved Mercury & $\mathrm{mg} / \mathrm{L}$ & $<0.000049$ & 0.000059 & $0.000074(\mathrm{tr})$ \\
\hline Dissolved Molybdenum & $\mathrm{mg} / \mathrm{L}$ & 0.026 (tr) & $0.033(\mathrm{tr})$ & $<0.0046$ \\
\hline Dissolved Nickel & $\mathrm{mg} / \mathrm{L}$ & 0.14 & 0.11 & 0.11 \\
\hline Dissolved Potassium & $\mathrm{mg} / \mathrm{L}$ & NA & 66.1 & 47.8 \\
\hline Dissolved Phosphorus & $\mathrm{mg} / \mathrm{L}$ & NA & 0.47 & $<0.312$ \\
\hline Dissolved Selenium & $\mathrm{mg} / \mathrm{L}$ & $<0.0085$ & 0.0034 & 0.0053 \\
\hline Dissolved Silver & $\mathrm{mg} / \mathrm{L}$ & $<0.00003$ & $<0.00003$ & $<0.00003$ \\
\hline
\end{tabular}




\begin{tabular}{|c|c|c|c|c|}
\hline Dissolved Sodium & $\mathrm{mg} / \mathrm{L}$ & NA & 1260 & 284 \\
\hline Dissolved Thallium & $\mathrm{mg} / \mathrm{L}$ & $<0.00034$ & $<0.00034$ & $<0.00034$ \\
\hline Dissolved Tin & $\mathrm{mg} / \mathrm{L}$ & $<<0.022$ & $<0.022$ & $<0.022$ \\
\hline Dissolved Vanadium & $\mathrm{mg} / \mathrm{L}$ & $0.023(\mathrm{tr})$ & $0.018(\operatorname{tr})$ & $<0.0032$ \\
\hline Dissolved Zinc & $\mathrm{mg} / \mathrm{L}$ & $0.027 *$ & 0.032 & 0.018 \\
\hline \multicolumn{5}{|l|}{ Volatile Organic Compounds: } \\
\hline Acetone & $\mu \mathrm{g} / \mathrm{L}$ & 12 & 23 & 8.8 \\
\hline Acrylonitrile & $\mu \mathrm{g} / \mathrm{L}$ & $<10$ & $<10$ & $<10$ \\
\hline Benzene & $\mu \mathrm{g} / \mathrm{L}$ & $0.43(\mathrm{tr})^{*}$ & $0.27(\mathrm{tr})^{*}$ & $0.17(\operatorname{tr})$ \\
\hline Bromobenzene & $\mu \mathrm{g} / \mathrm{L}$ & $<0.18$ & $<0.18$ & $<0.18$ \\
\hline Bromochloromethane & $\mu \mathrm{g} / \mathrm{L}$ & $<0.31$ & $<0.31$ & $<0.31$ \\
\hline Bromodichloromethane & $\mu \mathrm{g} / \mathrm{L}$ & $<0.14$ & $<0.14$ & $<0.14$ \\
\hline Bromoform & $\mu \mathrm{g} / \mathrm{L}$ & $<0.10$ & $<0.10$ & $<0.10$ \\
\hline Bromomethane (Methly bromide) & $\mu \mathrm{g} / \mathrm{L}$ & $<0.08$ & $<0.08$ & $0.23(\operatorname{tr})$ \\
\hline 2-Butanone (MEK) & $\mu \mathrm{g} / \mathrm{L}$ & 2.5 & $<1.0$ & $<0.12$ \\
\hline n-Butylbenzene & $\mu \mathrm{g} / \mathrm{L}$ & $<0.12$ & $<0.12$ & $<0.12$ \\
\hline sec-Butylbenzene & $\mu \mathrm{g} / \mathrm{L}$ & $<0.12$ & $<0.12$ & $<0.12$ \\
\hline tert-Butylbenzene & $\mu \mathrm{g} / \mathrm{L}$ & $<0.14$ & $<0.14$ & $<0.14$ \\
\hline Carbon Disulfide & $\mu \mathrm{g} / \mathrm{L}$ & $<1.0$ & $<1.0$ & $<1.0$ \\
\hline Carbon Tetrachloride & $\mu \mathrm{g} / \mathrm{L}$ & $<0.15$ & $<0.15$ & $<0.15$ \\
\hline Chlorobenzene & $\mu \mathrm{g} / \mathrm{L}$ & 2 & 2.8 & $0.23(\operatorname{tr})$ \\
\hline Chloroethane & $\mu \mathrm{g} / \mathrm{L}$ & $<0.34$ & $<0.34$ & $<0.34$ \\
\hline Chloroform & $\mu \mathrm{g} / \mathrm{L}$ & $<0.12$ & $<0.12$ & $<0.12$ \\
\hline Chloromethane (Methyl chloride) & $\mu \mathrm{g} / \mathrm{L}$ & $<0.25$ & $0.46(\mathrm{tr})$ & $0.33(\operatorname{tr})$ \\
\hline 2-Chlorotoluene & $\mu \mathrm{g} / \mathrm{L}$ & $<0.26$ & $0.31(\mathrm{tr})$ & $<0.26$ \\
\hline 4-Chlorotoluene & $\mu \mathrm{g} / \mathrm{L}$ & $<0.10$ & $<0.10$ & $<0.10$ \\
\hline Dibromochloromethane & $\mu \mathrm{g} / \mathrm{L}$ & $<0.40$ & $<0.40$ & $<0.40$ \\
\hline 1,2-Dibromo-3-chloropropane (DBCP) & $\mu \mathrm{g} / \mathrm{L}$ & $<0.95$ & $<0.95$ & $<0.95$ \\
\hline 1,2-Dibromoethane (EDB) & $\mu \mathrm{g} / \mathrm{L}$ & $<0.22$ & $<0.22$ & $<0.22$ \\
\hline Dibromomethane (Methly bromide) & $\mu \mathrm{g} / \mathrm{L}$ & $<0.21$ & $<0.21$ & $<0.21$ \\
\hline 1,2-Dichlorobenzene & $\mu \mathrm{g} / \mathrm{L}$ & $<0.14$ & $<0.14$ & $<0.14$ \\
\hline 1,3-Dichlorobenzene & $\mu \mathrm{g} / \mathrm{L}$ & $<0.11$ & $<0.11$ & $<0.11$ \\
\hline 1,4-Dichlorobenzene & $\mu \mathrm{g} / \mathrm{L}$ & $<0.13$ & $<0.13$ & $<0.13$ \\
\hline trans-1,4-Dichloro-2-butene & $\mu \mathrm{g} / \mathrm{L}$ & $<1.0$ & $<1.0$ & $<1.0$ \\
\hline Dichlorodifluoromethane (Freon 12) & $\mu \mathrm{g} / \mathrm{L}$ & $0.27(\mathrm{tr})$ & $<0.16$ & $<1.0$ \\
\hline 1,1-Dichloroethane (1,1-DCA) & $\mu \mathrm{g} / \mathrm{L}$ & $0.32(\mathrm{tr})$ & $0.16(\mathrm{tr})$ & $<0.10$ \\
\hline 1,2-Dichloroethane (1,2-DCA) & $\mu \mathrm{g} / \mathrm{L}$ & $<0.22$ & $<0.22$ & $<0.22$ \\
\hline 1,1-Dichloroethene (1,1-DCE) & $\mu \mathrm{g} / \mathrm{L}$ & $<0.36$ & $<0.36$ & $<0.36$ \\
\hline cis-1,2-Dichloroethene (cis-1,2-DCE) & $\mu \mathrm{g} / \mathrm{L}$ & $0.38(\mathrm{tr})$ & $0.20(\operatorname{tr})$ & $<0.10$ \\
\hline trans-1,2-Dichloroethene (trans-1,2-DCE) & $\mu \mathrm{g} / \mathrm{L}$ & $<0.11$ & $<0.11$ & $<0.11$ \\
\hline 1,2-Dichloropropane & $\mu \mathrm{g} / \mathrm{L}$ & $<0.15$ & $<0.15$ & $<0.15$ \\
\hline 1,3-Dichloropropane & $\mu \mathrm{g} / \mathrm{L}$ & $<0.20$ & $<0.20$ & $<0.20$ \\
\hline 2,2 Dichloropropane & $\mu \mathrm{g} / \mathrm{L}$ & $<0.13$ & $<0.13$ & $<0.13$ \\
\hline 1,1-Dichloropropene & $\mu \mathrm{g} / \mathrm{L}$ & $<0.14$ & $<0.14$ & $<0.14$ \\
\hline cis-1,3-Dichloropropene & $\mu \mathrm{g} / \mathrm{L}$ & $0.38(\mathrm{tr})$ & $<0.22$ & $<0.22$ \\
\hline trans-1,3-Dichloropropene & $\mu \mathrm{g} / \mathrm{L}$ & $<0.30$ & $<0.30$ & $<0.30$ \\
\hline Ethylbenzene & $\mu \mathrm{g} / \mathrm{L}$ & $<0.27$ & $<0.27$ & $<0.27$ \\
\hline Hexachlorobutadiene & $\mu \mathrm{g} / \mathrm{L}$ & $<0.22$ & $<0.22$ & $<0.22$ \\
\hline 2-Hexanone (Methyl butyl ketone) & $\mu \mathrm{g} / \mathrm{L}$ & $<1.0$ & $<1.0$ & $<1.0$ \\
\hline
\end{tabular}




\begin{tabular}{|c|c|c|c|c|}
\hline Iodomethane (Methyl iodide) & $\mu \mathrm{g} / \mathrm{L}$ & $<1.0$ & $<1.0$ & $<1.0$ \\
\hline Isopropylbenzene & $\mu \mathrm{g} / \mathrm{L}$ & $<0.12$ & $<0.12$ & $<0.12$ \\
\hline p-Isopropyltoluene & $\mu \mathrm{g} / \mathrm{L}$ & $<0.13$ & $<0.13$ & $<0.13$ \\
\hline Methyl-tert-butyl ether (MTBE) & $\mu \mathrm{g} / \mathrm{L}$ & 3 & $<1.0$ & $1.3(\operatorname{tr})$ \\
\hline 4-Methyl-2-pentanone (MIBK) & $\mu \mathrm{g} / \mathrm{L}$ & 3.8 & $<1.0$ & 3.3 \\
\hline Methylene Chloride & $\mu \mathrm{g} / \mathrm{L}$ & $0.35(\operatorname{tr})$ & $<0.35$ & $<0.35$ \\
\hline Naphthalene & $\mu \mathrm{g} / \mathrm{L}$ & $<0.15$ & $<0.15$ & $<0.15$ \\
\hline n-Propylbenzene & $\mu \mathrm{g} / \mathrm{L}$ & $<0.15$ & $<0.15$ & $<0.15$ \\
\hline Styrene & $\mu \mathrm{g} / \mathrm{L}$ & $<0.15$ & $<0.15$ & $<0.15$ \\
\hline 1,1,1,2-Tetrachloroethane & $\mu \mathrm{g} / \mathrm{L}$ & $<0.10$ & $<0.10$ & $<0.10$ \\
\hline $1,1,2,2$-Tetrachloroethane & $\mu \mathrm{g} / \mathrm{L}$ & $<0.37$ & $<0.37$ & $<0.37$ \\
\hline Tetrachloroethene (PCE) & $\mu \mathrm{g} / \mathrm{L}$ & $0.67(\operatorname{tr})$ & $0.60(\mathrm{tr})$ & $0.88(\mathrm{tr})$ \\
\hline Toluene & $\mu \mathrm{g} / \mathrm{L}$ & $0.35(\operatorname{tr})$ & $0.27(\mathrm{tr})^{*}$ & $<0.25$ \\
\hline 1,2,3-Trichlorobenzene & $\mu \mathrm{g} / \mathrm{L}$ & $<0.14$ & $<0.14$ & $<0.14$ \\
\hline 1,2,4-Trichlorobenzene & $\mu \mathrm{g} / \mathrm{L}$ & $<0.23$ & $<0.23$ & $<0.23$ \\
\hline $1,1,1$-Trichloroethane $(1,1,1-\mathrm{TCA})$ & $\mu \mathrm{g} / \mathrm{L}$ & $<0.41$ & $<0.41$ & $<0.41$ \\
\hline 1,1,2-Trichloroethane $(1,1,2$-TCA) & $\mu \mathrm{g} / \mathrm{L}$ & $<0.31$ & $<0.31$ & $<0.31$ \\
\hline Trichloroethene (TCE) & $\mu \mathrm{g} / \mathrm{L}$ & 1.6 & $0.83(\mathrm{tr})$ & $<0.31$ \\
\hline Trichlorofluoromethane (Freon 11) & $\mu \mathrm{g} / \mathrm{L}$ & $<0.23$ & $<0.23$ & $<0.23$ \\
\hline 1,2,3-Trichloropropane & $\mu \mathrm{g} / \mathrm{L}$ & $<0.30$ & $<0.30$ & $<0.30$ \\
\hline 1,2,4-Trimethylbenzene & $\mu \mathrm{g} / \mathrm{L}$ & $<0.12$ & $<0.12$ & $<0.12$ \\
\hline 1,3,5-Trimethylbenzene & $\mu \mathrm{g} / \mathrm{L}$ & $<0.14$ & $<0.14$ & $<0.14$ \\
\hline Vinyl Acetate & $\mu \mathrm{g} / \mathrm{L}$ & $<1.0$ & $<1.0$ & $<1.0$ \\
\hline Vinyl Chloride & $\mu \mathrm{g} / \mathrm{L}$ & $<0.12$ & $<0.12$ & $<0.12$ \\
\hline Total Xylenes & $\mu \mathrm{g} / \mathrm{L}$ & $0.34(\mathrm{tr})$ & $0.10(\mathrm{tr})$ & $<0.10$ \\
\hline
\end{tabular}

Footnotes:

$\mathrm{NA}=$ Not Analyzed

MDL=Method Detection Limit

PQL=Practical Quantification Limit

$<=$ Less than the MDL

$\operatorname{tr}=$ trace: the amount detected was above the MDL but below the PQL

$*=$ this parameter was alo detected in the method blank 